

\section{FICHA CATALOGRÁFICA}

Revista Vox Metropolitana [Recurso eletrônico] /

Faculdade Metropolitana da Grande Recife. - n. 06 Jaboatão dos Guararapes: FMGR, 2022.

Semestral

ISSN: 2674-8673

Disponível em: https://revistavox.metropolitana.edu.br

1. Produção acadêmica - Periódicos. 2. Faculdade Metropolitana da Grande Recife. I. Título

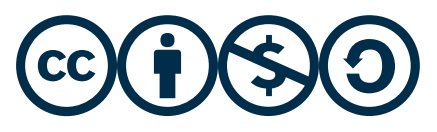




\section{REVISTAVOMX}

\section{APRESENTAÇÃO}

A Revista Vox Metropolitana é uma publicação semestral da Faculdade Metropolitana da Grande Recife (FMGR) voltada para a publicação de trabalhos acadêmicos por parte de professores e alunos dos cursos de graduação e pós-graduação desta e de outras instituições de ensino.

A Revista Vox Metropolitana está aberta para publicações de artigos originais ou de revisão, e relatos de experiências no formato de artigo científico.

Sua natureza apresenta foco multidisciplinar, publicando trabalhos diversos e resultados de pesquisas realizadas nas mais diversas áreas da ciência.

\section{Revista Vox Metropolitana}

https://revistavox.metropolitana.edu.br revistavox@metropolitana.edu.br

\section{Faculdade Metropolitana da Grande Recife}

Av. Barreto de Menezes, 809, Piedade Jaboatão dos Guararapes/PE CEP: $54.410-100$

Fones: 08005000500 (81) 2128-0500

Site: www.metropolitana.edu.br

Redes Sociais: instagram.com/fmgrecife 


\section{REVISTAVOKX}

\section{CORPO EDITORIAL}

\section{Editor Chefe}

- Arandi Maciel Campelo

\section{Conselho Editorial}

- Anderson Dacal Rocha (Mantenedor / Diretor Financeiro)

- Arandi Maciel Campelo

- Eline Isobel da Cunha Souza (Bibliotecária)

- Eronildo Ferreira do Carmo (Revisor - gramatical)

- Julio Miranda Vidal (Secretario Ejecutivo Consultivo Empresarial de la Escuela de Negocios / Universidad Mayor/Chile)

- Valber Marcel Bueno (Mantenedor / Diretor de Gestão de Ensino / Revisor diagramação)

\section{Comissão Editorial}

- Anderson Dacal Rocha (Mantenedor / Diretor Financeiro)

- Carlos Augusto da Silva Cavalcanti (Coordenador da Escola de Direito)

- Eline Isobel da Cunha Souza (Bibliotecária)

- Erinaldo Ferreira do Carmo (Docente Convidado da Universidade Federal de Pernambuco - UFPE)

- Eronildo Ferreira do Carmo (Revisor - gramatical)

- Fabiana Maria da Silva (Pesquisadora Institucional)

- Fábio José de Araújo Pedrosa (Docente Convidado da Universidade de Pernambuco - UPE)

- Gleydson Rocha de Souza (Coordenador da Escola de Saúde / Coordenador do Núcleo de Educação a Distância)

- Hermes Magalhães Junior (Coordenador da Escola de Gestão / Coordenador da Escola de Engenharia)

- João Biron de Oliveira Filho (Coordenador de Pós-graduação)

- Julio Miranda Vidal (Secretario Ejecutivo Consultivo Empresarial de la Escuela de Negocios / Universidad Mayor/Chile)

- Kariane Maria Arruda Vasconcelos (Secretária Acadêmica)

- Sthênio José Ferraz Magalhães (Coordenador da Escola de Ensino)

- Valber Marcel Bueno (Mantenedor / Diretor de Gestão de Ensino / Revisor diagramação) 


\section{REVISTAVOX}

\section{SUMÁRIO}

01 - A compreensão de professores do ensino infantil sobre a importância dos jogos e brincadeiras no processo de aprendizagem

02 - A contribuição da música para o desenvolvimento e aprendizagem na educação infantil

03 - Aplicação da Engenharia da Produção no diagnóstico qualitativo das aulas remotas durante a pandemia

04 - Comportamento humano nas organizações: desafios frente às mudanças entre os profissionais de um call center

05 - Contabilidade em organizações do terceiro setor: a prestação de contas de uma OSCIP em Recife

06 - Educação especial e inclusiva em tempos de pandemia

07 - Fatores motivacionais em uma empresa do segmento comercial na cidade de Recife

08 - Inclusão social: desafios de pessoas transgênero no ambiente de trabalho

09 - Inovação de processo em um call center: desfios de colaboradores em uma empresa de TV a cabo

10 - Intolerância às religiões afro-brasileiras no estado democrático de direito: perspectiva da teoria radical

11 - Liderança nas organizações: desafios de mulheres gestoras nos dias 156 atuais

12 - Marketing de relacionamento: um estudo de caso com clientes e lojistas do Shopping Guararapes

13 - Mudanças organizacionais: impactos e reações junto ao corpo funcional de uma escola de ensino infantil

14 - O impacto do e-Social para os profissionais de contabilidade em um município da Região Metropolitana do Grande Recife

15 - Os efeitos da pandemia nos hábitos comunitários: um estudo de caso sobre a feira livre (Pátio Novo) do bairro de Afogados em Recife/PE 


\title{
A COMPREENSÃO DE PROFESSORES DO ENSINO INFANTIL SOBRE A IMPORTÂNCIA DOS JOGOS E BRINCADEIRAS NO PROCESSO DE APRENDIZAGEM
}

\author{
https://dx.doi.org/10.48097/2674-8673.2022n6p01
}

\author{
Maria Gorete Santos de Andrade ${ }^{1}$ \\ Simeia Carolina Batista ${ }^{2}$ \\ Rosângela da Conceição G. Silva ${ }^{3}$ \\ Silvia Cavalcanti Isaltino ${ }^{4}$
}

\begin{abstract}
RESUMO
O processo de aprendizagem engloba diversos fatores que contribuem pontualmente e ativamente para o desenvolvimento de uma criança. O lúdico, os jogos e o brincar têm peso essencial nessa construção. Este artigo tem como objetivo analisar a utilização dos jogos como meio estratégico para a aprendizagem de crianças na educação infantil. Este estudo teve uma abordagem qualitativa e para o instrumento de coleta de dados foi utilizado um questionário com 5 (cinco) perguntas aplicadas a 4 (quatro) professoras. Foi possível verificar o entendimento geral e concordante de profissionais da educação quanto à importância desse material como recurso pedagógico. Percebeu-se também que os jogos são recursos propícios para a interação e relação da criança com o mundo ao seu redor, pois neles podem ser trabalhadas expressões corporais, verbais, sonoras e plásticas.
\end{abstract}

Palavras-chave: Jogos. Brincadeiras. Aprendizagem. Educação Infantil.

Data de submissão: 12/07/2021

Data de aprovação: 15/09/2021

\begin{abstract}
The learning process encompasses several factors that contribute promptly and actively to a child's development. The ludic, games and playing have essential weight in this construction. This article aims to analyze the use of games as a strategic means for learning children in early childhood education. This study had a qualitative approach and for the data collection instrument a questionnaire with 5 (five) questions applied to 4 (four) teachers was used. It was possible to verify the general and concordant understanding of education professionals regarding the importance of this material as a pedagogical resource. It was also noticed that the games are favorable resources for the child's interaction and relationship with the world around him, as in them bodily, verbal, sound and plastic expressions can be worked.
\end{abstract}

\footnotetext{
${ }^{1}$ Graduanda do Curso de Licenciatura em Pedagogia da Faculdade Metropolitana da Grande Recife. E-mail:mgoretesa@hotmail.com

${ }^{2}$ Graduanda do Curso de Licenciatura em Pedagogia da Faculdade Metropolitana da Grande Recife. E-mail: simeiacarolina@mail.com

${ }^{3}$ Graduanda do Curso de Licenciatura em Pedagogia da Faculdade Metropolitana da Grande Recife. E-mail: rosangela.larry@gmail.com

${ }^{4}$ Docente orientadora do Curso de Pedagogia da Faculdade Metropolitana da Grande Recife.

E-mail: silvinharca@hotmail.com
} 
Keywords: Games. Play. Learning. Child Education.

INTRODUÇÃO

A aprendizagem humana engloba diversos fatores que contribuem para o processo educativo infantil. Dentre esses, é possível citar os componentes sociais que dão sentido aos significados construídos pela criança. Logo, é importante considerar o tempo, ambiente físico, a família, a escola, os amigos e tudo o que compõe o contexto educativo infantil.

Através do levantamento bibliográfico realizado sobre o tema em questão foi possível perceber a contribuição da neurociência nesse processo, visto que a relação entre a recepção e a troca de informações entre diferentes centros nervosos e o meio social resulta na aprendizagem. Desta forma, ela inicia-se com um estímulo de natureza físico-química que vem do ambiente que é transformado em impulso nervoso pelos órgãos do sentido. (PAULA et al., 2006, p. 226).

Ademais, destacam-se também estudos a respeito dos jogos e brincadeiras como recursos mediadores do processo de ensino-aprendizagem, possibilitando que seja conduzido de maneira mais divertida e eficaz. Para isso, se faz importante o trabalho do professor no sentindo de criar estratégias, ações e intervenções que venham a contribuir e potencializar o desempenho da criança no ambiente escolar, ou seja, brincando e jogando a criança terá oportunidades de desenvolver capacidades indispensáveis a sua futura formação e atuação profissional, tais como: atenção, afetividade, concentração e outras habilidades perceptuais psicomotoras. (ALVES; BIANCHIN, 2010, p. 284). Cabe aqui destacar que a brincadeira deve ser livre e de forma espontânea. Já o jogo também é uma brincadeira, porém com regras.

Dessa forma, o presente estudo objetiva compreender a concepção dos professores no que diz respeito à importância dos jogos e das brincadeiras na educação escolar, bem como a forma como esses entendem a contribuição da neurociência para o processo de aprendizagem.

A motivação na escolha do tema encontra-se no ensejo de um conhecimento mais amplo e detalhado sobre o assunto abordado e pelo entendimento de que o ato de ensinar, sendo feito através do brincar, representa um caminho mais prazeroso e significativo, o qual conduz a uma aprendizagem mais ampla na perspectiva de uma formação humana mais completa. Acredita-se que, dessa forma, a discussão de tal tema possa ser aprimorada, contribuindo assim nos estudos da área. 


\title{
FUNDAMENTAÇÃO TEÓRICA
}

Discutir sobre o processo de aprendizagem humana requer a necessária compreensão de como o cérebro se organiza para assim entender como os estudos da neurociência podem ajudar no trabalho do professor. De acordo com Sousa e Alves (2017:

\begin{abstract}
O aprendizado é um processo complexo e dinâmico que resulta em modificações estruturais e funcionais do sistema nervoso central. As alterações ocorrem a partir de um ato motor e perceptivo, que, elaborado no córtex cerebral, dá início à cognição. No processo neuropsicológico do ato de aprender, a atenção, a memória e as funções executivas assumem um papel de fundamental importância. (SOUZA; ALVES, 2017, p. 326).
\end{abstract}

\section{As contribuições da neurociência para a aprendizagem}

O ser humano absorve as percepções como sensações que chegam pelos órgãos dos sentidos que seguidamente são interpretadas pelo cérebro, junto das memórias e pensamento, e assim são transmitidas às diferentes áreas do sistema nervoso por meio dos neurônios. (ALVAREZ; LEMOS 2006, p. 187). E como são transmitidas essas informações? Existem substâncias químicas que ficam armazenadas nos neurônios. Essas substâncias também são conhecidas como neurotransmissores e são responsáveis por essa troca de informação. Acetilcolina e serotonina são tipos de neurotransmissores e cada um é responsável por uma ação diferente no organismo. Segundo Santos (2005), "a função da acetilcolina está associada à memória, estimulação e atenção; já a serotonina está associada ao estado de humor, vigilância e cognição".

Memória, atenção, estimulação, vigilância e cognição são fatores essenciais para o aprendizado. De acordo com Souza e Salgado (2015, p. 144), a aquisição da memória e o aprendizado são sinônimos. As autoras alegam que só se pode gravar aquilo que foi aprendido. Do mesmo modo, só podemos gravar e, posteriormente lembrar, aquilo que aprendemos. Colaborando com esse pensamento Ganz et al. (2015, p. 16) concluem que "habilidades cognitivas, como memória e atenção, são importantes para o desenvolvimento da aprendizagem acadêmica, para o desenvolvimento da linguagem e aquisição de controle do comportamento".

O estudo de Relva (2012), citado por Pinho (2018, p. 81), afirma que é possível aprender, desenvolver habilidades e adquirir conhecimento através da capacidade que o cérebro tem de se modificar. De acordo com a autora a aprendizagem consiste em modificar o cérebro por meio da prática pedagógica. Essa capacidade de modificação que o 
cérebro tem é chamada de plasticidade neural. Como afirmam Haase e Lacerda (2004, p. 29), plasticidade neural é a capacidade do sistema nervoso de modificar sua estrutura e função em decorrência dos padrões de experiência, ou seja, o cérebro, quando estimulado, cria novos caminhos e assim vamos adquirindo novas habilidades.

Portanto, entender essas informações é de suma importância para relacionar o ato do brincar como chave para um caminho de um desenvolvimento rico e proveitoso, pois se entende que ao fazê-lo a criança trabalha a atenção, memória, prazer e felicidade, servindo de aporte para o profissional de educação, favorecendo a autonomia da criança, estimulando o interesse da mesma e, consequentemente, auxiliando no seu processo de aprendizagem.

\section{Os jogos e as brincadeiras na condução do processo de ensino-aprendizagem}

Embora pareça só diversão o ato de brincar é um momento de desenvolvimento, pois envolve percepção, cognição, interação social, autoconhecimento com o corpo, coordenação motora, entre outros. "A aprendizagem e o desenvolvimento acontecem do plano social para o individual.” (JACOMETO; TABILE, 2017, p. 79).

De acordo com Pereira (2010), cada sujeito aprende a seu modo, do seu jeito, dentro de um ritmo e tempo próprio. As intervenções internas e/ou externas são motivações e estímulos que produzem no sujeito uma forma muito especial de aprender. Vygotisk (1991 apud ROSA et al., 2010, p. 12), entende que a brincadeira é um meio que a criança supre algumas necessidades, como também um meio de aprendizado, meio de desenvolver sua imaginação, compreender a realidade, regras e situações imaginárias que são a base para o pensamento abstrato adulto.

Para falar sobre o brincar e o lúdico devemos compreender e explorar um pouco mais sobre a cultura lúdica. Considerando que cada cultura tem seus aspectos, é possível compreender que isso intervém diretamente no brincar da criança. Brougère (1998 apud ROSA et al., 2010, p. 09) diz que "cada cultura irá determinar o que serão comportamentos típicos de brincadeira e comportamentos que não serão de brincar”. Esta declaração pode soar como imprecisa, porém se pensarmos que a cultura pode influenciar na brincadeira de tal forma a dizer e orientar com quem brincar, onde brincar e como brincar ela torna-se válida.

Cordazzo e Vieira (2007, p. 91) destacam que "a brincadeira é definida como uma atividade livre, que não pode ser delimitada e que, ao gerar prazer, possui um fim em si mesma." 
$\mathrm{O}$ ato da aprendizagem é inerente tão somente ao ser humano. Os animais conseguem ser adestrados, mas não desenvolvem competências. Essas são fruto de aprendizagens. Um cão nasce cão e ninguém precisa ensiná-lo a latir, ou seja, nenhum animal a não ser o ser humano precisa se autoconstruir, precisa se fazer ele mesmo. O animal tem um gene que o autodetermina, pois ele já nasce com todos os pressupostos comportamentais dele. O ser humano nasce com um potencial de aprender, não nasce com esse gene autodeterminante, logo, nós temos que aprender a sermos nós mesmos. Temos que aprender a falar, a nos relacionar, a viver em comunidade, isso tudo por que não nascemos completos, nós nos construímos e nos desenvolvemos justamente por que temos a capacidade e habilidade de aprender.

O lúdico como recurso pedagógico direcionado à alfabetização pode ser considerado praticamente um princípio. Explorar a ludicidade, as brincadeiras, juntamente com os jogos, é a oportunidade de inserir regras, despertar interesses, raciocínio, onde a criança pode seguir um percurso traçando metas. Através do lúdico o professor pode oferecer ao aluno atividades que sejam interessantes e significativas, que desafiam e motivam o aluno, identificando possíveis habilidades como também possíveis dificuldades.

O desafio do professor consiste em criar estratégias para que o aluno supere essas dificuldades e, se a criança aprende através do brincar, nada mais evidente que a utilização dos jogos e brincadeiras como recurso didático. Como já foi citado o brincar deve ser livre, mas o jogo deve ser direcionado, pois existem regras estabelecidas, porém ambos têm a mesma finalidade e proporcionam um enriquecimento na construção de conhecimento da criança.

Incorporar o jogo como proposta pedagógica é um comprometimento com a prática profissional. De acordo com Lima et al. (2012), o trabalho direto com crianças exige que o professor, na sua prática docente, tenha grande competência e habilidade polivalente. Nesse sentido, ser polivalente significa que o professor, na materialização da sua prática, cabe trabalhar com conteúdos de naturezas diversas que abrangem alguns cuidados básicos essenciais com conhecimentos específicos oriundos das diversas áreas do conhecimento na sua atuação.

Deste modo, a prática docente diante das dificuldades de aprendizagem consiste em ressignificar suas ações dentro de sala, podendo construir um rico panorama de estratégias que possam ser colocadas em prática, abrangendo as necessidades e interesses dos alunos. 


\section{METODOLOGIA}

O presente artigo foi realizado através da abordagem qualitativa. De acordo com Godoy (1995), esse método de pesquisa ocupa um reconhecido lugar no estudo dos fenômenos que envolvem os seres humanos e as suas relações sociais estabelecidas em diversos ambientes. Com a finalidade de alcançar os objetivos propostos, foi feito um levantamento bibliográfico, visando fornecer melhor embasamento teórico para a discussão do tema em questão.

Posteriormente foi realizado um estudo de campo, o qual procurou um maior aprofundamento do tema com vistas a captar as explicações e interpretações dos participantes sobre o que ocorre naquela realidade. (GIL, 2008). Tal coleta de dados aconteceu através da aplicação de questionários a 4 (quatro) professoras que atuam na educação infantil em escolas da rede privada de ensino do município de Jaboatão dos Guararapes, no estado de Pernambuco. As participantes foram aqui identificadas por professora A, professora B, professora C e professora D.

Por conta da pandemia da COVID-19 a aplicação do questionário aconteceu de forma online, através do aplicativo de mensagem WhatsApp, em dia e horário escolhidos pelas participantes. Todas elas possuem mais de 10 anos de experiência em sala de aula e contam com especialização na área de educação infantil, exceto a professora " $C$ " que ainda não concluiu a sua especialização e atua há apenas um ano na área. Após a realização e análise dos questionários, os dados foram organizados e discutidos, conforme será discutido no capítulo seguinte.

\section{RESULTADOS E DISCUSSÕES}

Nesta etapa abordamos as respostas obtidas através de perguntas realizadas na entrevista. No que diz respeito à compreensão das professoras sobre a contribuição da neurociência é notável o entendimento em comum dessas em relação à importância de conhecer como se dá o processo de aprendizagem e como funciona o cérebro da criança, conforme é possível verificar nos recortes de falas abaixo:

Os estudos da neurociência contribuem para o entendimento do processo de aprendizagem da criança, pois une conhecimentos biológicos, cognitivos e pedagógicos. (Professora A).

Entendo que através da neurociência é possível entender que todos os alunos são capazes de aprender algo novo dia após dia através da interação, motivação, emoção, entre outras coisas. (Professora B).

Entendo a importância dos estudos da neurociência como norte para o 
entendimento da aprendizagem humana, deveria ter uma disciplina voltada para esse contexto ainda na graduação. (Professora C).

A neurociência contribui para direcionamentos da aprendizagem, considerando que existe uma variedade de comportamentos em sala de aula. (Professora D).

Conforme o exposto em nosso referencial teórico, a percepção, memória, emoção, cognição, linguagem, movimento, atenção, pensamento, entre outros, são objetos de estudo da neurociência e todos esses componentes são cruciais para a aprendizagem. Como diz Pinho (2018):

A aprendizagem ocorre porque há, no cérebro, mecanismos que permitem a realização de processos relacionados à cognição, como as funções cognitivas, responsáveis pela atenção, pela memória, pelo processamento das informações e pelo uso da linguagem. (PINHO, 2018, p. 80).

Destaca-se a fala da professora $\mathrm{C}$ em que a mesma sugere que deveria haver uma disciplina voltada para esse assunto ainda na graduação. $\mathrm{Na}$ resolução $\mathrm{CNE} / \mathrm{CP} \mathrm{N}^{0}$ 1/06 encontramos as Diretrizes Curriculares Nacionais para o Curso de Graduação em Pedagogia. Este documento, no art. $2^{\circ}, \S 2^{\circ}$ informa que o curso de Pedagogia, por meio de estudos teórico-práticos, investigação e reflexão crítica, propiciará:

I - o planejamento, execução e avaliação de atividades educativas; II - a aplicação ao campo da educação, de contribuições, entre outras, de conhecimentos como o filosófico, o histórico, o antropológico, o ambientalecológico, o psicológico, o linguístico, o sociológico, o político, o econômico, o cultural. (BRASIL, 2006).

A partir dessas orientações das Diretrizes Curriculares Nacionais do curso de graduação em Pedagogia entendemos que existe um leque de conteúdo que serve de alicerce para o início da vida profissional do recém-graduado, porém, não descartamos a importância dos estudos da neurociência. Com isto, neste mesmo documento, ainda encontramos no seu art. $3^{\circ}$ informações que discorrem sobre o futuro trabalho do estudante:

O estudante de Pedagogia trabalhará com um repertório de informações e habilidades composto por pluralidade de conhecimentos teóricos e práticos, cuja consolidação será proporcionada no exercício da profissão, fundamentando-se em princípios de interdisciplinaridade, contextualização, democratização, pertinência e relevância social, ética e sensibilidade afetiva e estética. (BRASIL, 2006).

A partir dessas informações cabe aqui dar ênfase na formação continuada do profissional, partindo do princípio dessa pluralidade não só de conhecimento, mas também de alunos com quem o professor lida diariamente. Essa diversidade exige que o profissional se especialize e aprofunde-se cada vez mais em sua área de atuação, pois 
apenas a graduação não vai proporcionar arcabouço suficiente para suas atividades.

Já no que se refere à utilização de jogos e brincadeiras na educação infantil, o entendimento das participantes se dá no sentido de reconhecer a importância desses elementos para a aprendizagem, desde que contem com a orientação do professor na condução de tais atividades lúdicas. É necessário que exista um planejamento das atividades a serem utilizadas para assim garantir que as crianças possam evoluir no processo educativo. Podemos verificar abaixo recortes das falas das professoras:

\footnotetext{
É importante que a criança receba orientação enquanto utiliza o jogo e para que isso aconteça é necessário planejamento das atividades a serem utilizadas, deste modo é possível promover noções de convívio social, regras, respeito e autonomia. (Professora A).

É através do jogo e da brincadeira o aluno se entusiasma, aprende sem perceber, aprende brincando. (Professora B).

O jogo e a brincadeira facilita a compreensão das coisas ao redor do aluno e dessa forma aumenta sua criatividade. (Professora C).

A brincadeira não só contribui para autonomia do aluno, contribui também para seu desenvolvimento, relacionamento com os colegas de sala e assimilação de conteúdo. (Professora D).
}

Dessa forma, observa-se que tais concepções estão em concordância com o que apontam os estudos da área. De acordo Queiroz et al. (2006, p. 176), "cabe ao professor, como adulto mais experiente, estimular brincadeiras e jogos, ordenar o espaço interno e externo da escola, facilitar a disposição dos brinquedos, mobiliário, e os demais elementos da sala de aula".

Por fim, em relação à preferência sobre as brincadeiras ou jogos e o momento em que estes são utilizados, as professoras entrevistadas citaram: a brincadeira de roda, o desfecho da toalha, jogos com peças de montar (lego), brincadeiras com bexigas e um jogo chamado siga a linha. Abaixo podemos observar recortes das falas das profissionais:

Gosto de brincadeiras lúdicas, como por exemplo, o desfecho da toalha, é uma brincadeira que posso trabalhar a coordenação motora. (Professora A).

Utilizo tanto o jogo como a brincadeira, jogos de construção, o jogo siga a linha e brincadeiras de roda. (Professora $\mathrm{B}$ ).

Uma vez na semana utilizo o recurso lúdico, nesse caso usamos muito o jogo de peças das peças de montar (lego). (Professora C).

Gosto de utilizar tanto o jogo como as brincadeiras, mas acho que a brincadeira lúdica motiva mais as crianças, como por exemplo; a brincadeira da bexiga. (Professora D).

Podemos observar na literatura que a utilização dos jogos e brincadeiras, como 
recurso pedagógico, é uma rica forma de aprendizagem e ensinamento. Alves e Bianchin (2010, p. 283) confirmam a função benéfica do jogo na vida de uma criança quando dizem que jogando a criança experimenta, inventa, descobre, aprende e confere habilidades, pois sua inteligência e sua sensibilidade estão sendo desenvolvidas. Assim, a qualidade de oportunidades que são oferecidas à criança por meio de jogos garante que suas potencialidades e sua afetividade se harmonizem.

\section{CONSIDERAÇÕES FINAIS}

O presente artigo teve como objetivo principal compreender, a partir da concepção dos professores da educação infantil, a importância dos jogos e brincadeiras no processo de aprendizagem. Foi possível comprovar a importância da utilização desses recursos para a aprendizagem da criança, visto que essas atividades funcionam como mediadoras e facilitam a obtenção de diversos conhecimentos e um melhor desenvolvimento escolar.

Para isso, destaca-se a o papel do professor no sentido de conduzir um processo de ensino-aprendizagem de forma lúdica, mas bem pensada e planejada para assim alcançar o êxito no seu trabalho. O professor/psicopedagogo é visto como possibilitador da construção de conhecimento, proporcionando aos alunos uma visão de mundo mais ampla e contribuindo para seu desenvolvimento pleno e saudável.

Os estudos da neurociência na concepção das professoras é incontestavelmente importante, pois o fato de entender como o cérebro funciona serve de aporte para direcionar o trabalho em sala de aula.

O exercício desta profissão requer estudos contínuos. Este artigo marca o início de uma vida acadêmica e não deverá ser finalizado aqui, merecendo ser aprofundado. $\mathrm{Na}$ prática, a atuação na educação infantil exige diversos desafios e requer do professor a mobilização de diversos saberes, seja ele o saber adquirido em especializações ou adquirido através de sua experiência profissional.

\section{REFERÊNCIAS}

ALVAREZ, Ana; LEMOS, Ivana de Carvalho. Os neurobiomecanismos do aprender: a aplicação de novos conceitos no dia-a-dia escolar e terapêutico. Rev. psicopedag. São Paulo, v. 23, n. 71, p. 181-190, $2006 . \quad$ Disponível em: http://pepsic.bvsalud.org/scielo.php?script=sci_arttext\&pid=S010384862006000200011\&1 n g=pt\&nrm=iso. Acesso em: 03 set. 2020. 
ALVES, Luciana; BIANCHIN, Maysa Alahmar. O jogo como recurso de aprendizagem. Rev. psicopedag. São Paulo, v. 27, n. 83, p. 282-287, 2010. Disponível em: http://pepsic.bvsalud.org/scielo.php?script=sci_arttext\&pid=S010384862010000200013\&1 $\mathrm{n} \mathrm{g}=\mathrm{pt \& nrm}=$ iso. Acesso em: 17 ago. 2020.

BRASIL. Conselho Nacional de Educação. Resolução CNE/CP no 01/06. Diretrizes Curriculares Nacionais para o Curso de Graduação em Pedagogia. Brasília, DF. 2006. Disponível em: http://portal.mec.gov.br/cne/arquivos/pdf/rcp01_06.pdf. Acesso em: 09 set. 2020.

CORDAZZO, Scheila Tatiana Duarte; VIEIRA, Mauro Luís. A brincadeira e suas implicações nos processos de aprendizagem e de desenvolvimento. Estud. pesqui. psicol., Rio de Janeiro , v. 7, n. 1, jun. 2007. Disponível em: http://pepsic.bvsalud.org/scielo.php?script=sci_arttext\&pid=S180842812007000100009\&ln $\mathrm{g}=$ pt\&nrm=iso. Acesso em: 03 out. 2020.

GANZ, Jucelia Santos et al . Programa de estimulação cognitiva "ativamente" para o ensino infantil: a cognitive stimulation program for preschool children. Rev. psicopedag. São Paulo, v. 32, n. 97, p. 14-25, $2015 . \quad$ Disponível em: http://pepsic.bvsalud.org/scielo.php?script=sci_arttext\&pid=S010384862015000100003\&ln $\mathrm{g}=\mathrm{pt \& nrm}=$ iso. Acesso em: 07 jul. 2020.

GIL, Antonio Carlos. Como elaborar projetos de pesquisa. 4. ed. São Paulo: Atlas, 2008.

GODOY, Arilda Schmidt. Pesquisa qualitativa: tipos fundamentais. Rev. adm. empres., São Paulo, v. 35, n. 3, p. 20-29, jun $1995 . \quad$ Disponível em: http://www.scielo.br/scielo.php?script=sci_arttext\&pid=S003475901995000300004\&lng=en $\&$ nrm=iso. Acesso em: 05 Out. 2020.

HAASE, Vitor Geraldi; LACERDA, Shirley Silva. Neuroplasticidade, variação interindividual e recuperação funcional em neuropsicologia. Temas psicol. Ribeirão Preto, v. 12, n. 1, p. 28-42, jun. $2004 . \quad$ Disponível em: http://pepsic.bvsalud.org/scielo.php?script=sci_arttext\&pid=S1413389X2004000100004\&1 $\mathrm{n} \mathrm{g}=\mathrm{pt} \& \mathrm{nrm}=\mathrm{iso}$. Acesso em: 03 out. 2020.

LIMA, Rita Carla; SÉRGIO, Maria Cândida; SOUZA, Adriana Cristina de. A prática docente do professor da educação infantil: contribuições para o desenvolvimento das crianças. Revista e-Curriculum [online]. 2012, 8(1), 1-24 ISSN: 1809-3876. Disponível em:

https://www.redalyc.org/articulo.oa?id=76623542004. Acesso em: 04 Out. 2020.

PAULA, Giovana Romero et al . Neuropsicologia da aprendizagem. Rev. psicopedag. São Paulo, V. 23, n. 72, p. 224-231, $2006 . \quad$ Disponível em: http://pepsic.bvsalud.org/scielo.php?script=sci_arttext\&pid=S010384862006000300006\&ln $\mathrm{g}=\mathrm{pt \& nrm}=$ iso. Acesso em: 19 set. 2020.

PEREIRA, Débora Silva de Castro. $O$ ato de aprender e o sujeito que aprende. Constr. 
psicopedag. São Paulo, v. 18, n. 16, p. 112-128, jun. 2010. Disponível em: http://pepsic.bvsalud.org/scielo.php?script=sci_arttext\&pid=S141569542010000100010\&ln $\mathrm{g}=$ pt\&nrm=iso. Acesso em: 01 set. 2020.

PINHO, Louise Silva do. Neurociência cognitiva na sala de aula: estratégias de ensino de Língua Espanhola. Let. Hoje. Porto Alegre, v. 53, n. 1, p. 80-88, Mar. 2018. Disponível em: http://www.scielo.br/scielo.php?script=sci_arttext\&pid=S 198477262018000100080\&lng=en \&nrm=iso. Acesso em: 07 Ago. 2020.

QUEIROZ, Norma Lucia Neris de; MACIEL, Diva Albuquerque; BRANCO, Angela Uchôa. Brincadeira e desenvolvimento infantil: um olhar sociocultural construtivista. Paidéia (Ribeirão Preto), Ribeirão Preto , v. 16, n. 34, p. 169-179, Ago. 2006 . Disponível em: http://www.scielo.br/scielo.php?script=sci_arttext\&pid=S0103863X2006000200005\&lng=e n\&nrm=iso. Acesso em: 05 jun. 2020.

ROSA, Fabiane Vieirada; KRAVCHYCHYN, Helena; VIEIRA, Mauro Luis. Brinquedoteca: a valorização do lúdico no cotidiano infantil da pré-escola. Barbaroi, Santa Cruz do Sul, n. 33,p. 8-27, dez. 2010. Disponível em:http://pepsic.bvsalud.org/scielo.php?script=sci_arttext\&pid=S01046578201000020000 $2 \& \operatorname{lng}=$ pt\&nrm=iso. Acesso em: 29 ago. 2020.

SANTOS, Franklin Santana. Mecanismos fisiopatológicos do delirium. Rev. psiquiatr. clín. São Paulo, v. 32, n. 3, p. 104-112, junho de 2005. Disponível em: http://www.scielo.br/scielo.php?script=sci_arttext\&pid=S010160832005000300002\&lng=en $\&$ nrm=iso. Acesso em: 10 set. 2020.

SOUSA, Aline Batista de; SALGADO, Tânia Denise Miskinis. Memória, aprendizagem, emoções e inteligência. Revista Liberato, Novo Amburgo, 2015, v.16, n.26, p.101-220, Jul/Dez. disponível em: https://lume.ufrgs.br/handle/10183/132515. Acesso em: 10 ago. 2020.

SOUSA, Anne Madeliny Oliveira Pereira de; ALVES, Ricardo Rilton Nogueira. A neurociência na formação dos educadores e sua contribuição no processo de aprendizagem. Rev. psicopedag. São Paulo , v. 34, n. 105, p. 320-331, 2017. Disponível em: http://pepsic.bvsalud.org/scielo.php?script=sci_arttext\&pid=S010384862017000300009\&ln $\mathrm{g}=\mathrm{pt \& nrm}=$ iso. Acesso em: 02 jul. 2020.

TABILE, Ariete Fröhlich; JACOMETO, Marisa Claudia Durante. Fatores influenciadores no processo de aprendizagem: um estudo de caso. Rev. psicopedag. São Paulo, v. 34, n. 103, p.

75-86, 2017.

Disponível em:

http://pepsic.bvsalud.org/scielo.php?script=sci_arttext\&pid=S010384862017000100008\&ln $\mathrm{g}=$ pt\&nrm=iso. Acesso em: 01 out. 2020. 


\section{APÊNDICE A - Roteiro da entrevista aplicada às professoras}

$1^{\circ}$ Qual sua opinião sobre a contribuição da neurociência para seu trabalho em sala de aula?

$2^{\circ}$ Qual a importância dos jogos e brincadeiras na educação infantil?

$3^{\text {o }}$ Você costuma utilizar recursos lúdicos em sala de aula? Quais?

$4^{\circ}$ Em que momentos da aula esses recursos são utilizados?

$5^{\circ}$ De que forma a ludicidade pode contribuir para o desenvolvimento da autonomia da criança? 


\title{
A CONTRIBUIÇÃO DA MÚSICA PARA O DESENVOLVIMENTO E APRENDIZAGEM NA EDUCAÇÃO INFANTIL
}

\author{
https://dx.doi.org/10.48097/2674-8673.2022n6p02
}

\author{
Jéssica Azevedo Silva ${ }^{1}$ \\ Rafaela Priscila Lima da Silva ${ }^{2}$ \\ Vanessa Cordeiro Vieira ${ }^{3}$ \\ Silvia R. C. Alves Isaltino ${ }^{4}$
}

\section{RESUMO}

Este artigo tem como finalidade compreender o envolvimento da música no processo de desenvolvimento e aprendizagem na educação infantil pelas alunas do curso de Pedagogia da Faculdade Metropolitana da Grande Recife. O estudo teve como objetivo Compreender o impacto da música no desenvolvimento e aprendizagem na educação infantil. O levantamento e a análise foram realizados por meio de uma pesquisa qualitativa exploratória, com entrevista semiestruturada, aplicada no ano de 2020. A amostra revelou que as entrevistadas destacam a importância de se trabalhar com a música no ambiente escolar e os benefícios que a mesma traz.

Palavras-chave: Música. Desenvolvimento. Aprendizagem. Educação Infantil.

Data de submissão: $16 / 08 / 2021$

Data de aprovação: 19/09/2021

\begin{abstract}
This article aims to understand the involvement of music in the process of development and learning in early childhood education by students of the Pedagogy course at Faculdade Metropolitana da Grande Recife. The study aimed to understand the impact of music on development and learning in early childhood education. The survey and analysis were carried out through an exploratory qualitative research, with semi-structured interviews, applied in 2020. The sample revealed that the interviewees highlight the importance of working with music in the school environment and the benefits it brings.
\end{abstract}

Keywords: Music. Development. Learning. Child education.

\section{INTRODUÇÃO}

O presente trabalho visa estudar a música na educação infantil, buscando

\footnotetext{
${ }^{1}$ Concluinte do curso de Pedagogia da Faculdade Metropolitana da Grande Recife.

E-mail: jessicaazevedosilva90@gmail.com

${ }^{2}$ Concluinte do curso de Pedagogia da Faculdade Metropolitana da Grande Recife.

E-mail: rafa_pri.com@hotmail.com

${ }^{3}$ Concluinte do curso de Pedagogia da Faculdade Metropolitana da Grande Recife.

E-mail: vanessacv1997@hotmail.com

${ }^{4}$ Docente orientadora do curso de Pedagogia da Faculdade Metropolitana da Grande Recife.

E-mail: silvinharca@hotmail.com
} 
compreender qual a sua relação com o processo de desenvolvimento e aprendizagem das crianças nessa fase educativa e o impacto que ela provoca dentro do contexto escolar.

Conforme se sabe, a música é uma linguagem muito importante para o desenvolvimento humano, pois é um meio de expressar sentimentos, ideias, emoções, pensamentos, etc. Intimamente relacionada com a cultura local, a música faz parte de momentos e situações sociais, podendo, inclusive, estar presente antes mesmo do nascimento da criança, quando esse contato acontece ainda no ventre da mãe. A musicalidade também aparece em rituais como casamentos, nascimentos, mortes, recuperação de doenças e fertilidade. Assim, conforme aponta Bréscia (2003), a música faz parte de diversas culturas, em todos os aspectos da história em que o ser humano está inserido, desde as primeiras civilizações.

É nesse contexto que se ressalta a relevância da música na educação infantil, abordando o desenvolvimento em uma perspectiva lúdica, facilitando, assim, a aprendizagem da criança, através de suas expressões e emoções. O ensino de leitura e escrita através da música funciona como um processo mediador que tem como finalidade desenvolver e potencializar a construção de conhecimentos e habilidades, contribuindo na formação da criança.

Deste modo, a música está muito ligada ao lúdico e ao brincar. Em todos os povos as crianças brincam com a música. Jogos e brinquedos musicais, como as rodas cantadas, são encontrados nos lugares onde houver crianças. (UNESCO, 2005).

Somada ao fato acima exposto, a motivação da pesquisa surge devido à experiência profissional e pessoal das presentes pesquisadoras, pois se identificam bastante com o tema e o reconhecem como recorrente nos dias atuais, podendo trazer benefícios tanto na relação do professor com os alunos como na relação dos alunos entre si. Dessa forma, pretende-se contribuir com as discussões e os estudos da área e ampliar a compreensão sobre o impacto da musicalidade no contexto educacional.

\section{FUNDAMENTAÇÃO TEÓRICA}

Em relação à educação infantil, a música tem um papel indispensável na vida da criança, pois contribui para a formação cognitiva, física, mental e social do indivíduo, incentivando também os cuidados com o corpo e a alimentação. Para isso, Moreno (2007) destaca que “o trabalho pedagógico na educação infantil deve 
respeitar a criança quanto aos seus direitos e especificidades, isto é, sua essência lúdica, sua constante curiosidade, seu desenvolvimento".

\section{A música e o desenvolvimento humano}

Observando a música na história da humanidade é possível perceber que ela é fundamental na vida dos seres humanos, estando presente em diferentes momentos, desde a antiguidade, fazendo parte das mais variadas culturas e regiões. Nesse sentido, Góes (2009) ressalta que:

A presença da música na vida dos seres humanos é incontestável. Ela tem acompanhado a história da humanidade, ao longo dos tempos, exercendo as mais diferentes funções. Está presente em todas as regiões do globo, em todas as culturas, em todas as 12 épocas, ou seja, a música é uma linguagem universal, que ultrapassa as barreiras do tempo e do espaço. (GÓES, 2009, p. 2).

Além disso, a música pode contribuir para o desenvolvimento humano, visto que é uma importante forma de comunicação e está presente em diferentes etapas da vida humana, trazendo benefícios para este processo formativo. (NOGUEIRA, 2003).

Dentro do contexto escolar a música também tem a sua contribuição, funcionando para fortalecer os vínculos aluno-aluno e professor-aluno, além de ter a capacidade de desenvolver a psicomotricidade, as expressões, o equilíbrio, a autoestima, o autoconhecimento, etc.

Segundo o Referencial Curricular Nacional para a Educação Infantil, do Ministério da Educação e do Desporto:

O trabalho com a música deve considerar, portanto, que ela é um meio de expressão e forma de conhecimento acessível aos bebês e crianças, inclusive aquelas que apresentam necessidades especiais. A linguagem musical é excelente meio para o desenvolvimento da expressão do equilíbrio da autoestima e autoconhecimento, além de poderoso meio de interação social. (BRASIL, 1998, p. 49).

Assim, destaca-se que há uma grande variedade de formas para trabalhar a música na sala de aula. Esta deve ser valorizada também nos momentos da brincadeira, pois se compreende que brincando também se aprende. A forma de musicalidade lúdica é uma maneira prazerosa de compreender e aprender gestos, sílabas, sons e pronúncias.

Conforme descrição de Arribas (2006):

O ritmo na música é a maneira de suceder-se e alternarem-se os sons (sílabas, pulsações), e destes, seus acentos fortes e fracos, suas durações curtas ou longas. A melodia, procedente a linguagem, é a linha horizontal da 
música (um som após o outro) A harmonia é a fusão e a simultaneidade dos sons, é a verticalidade da música. (ARRIBAS, 2006, p. 245).

Ao colocar uma música o professor pode incentivar as crianças com gestos, danças ou até mesmo com os próprios sons corporais. Brincadeiras como danças de roda e danças da cadeira possibilitam o desenvolvimento da concentração. Ademais, a música permite o autocontrole do próprio corpo, melhora a postura, percepção auditiva, noção rítmica e espacial, incentivando também o desenvolvimento da linguagem. Nesse sentido, Oliveira (1997) destaca:

\begin{abstract}
A fala para a criança é um ato motor organizado, exige, além de uma adequada percepção auditiva e visual, um conhecimento e controle do corpo, através das posturas e gestos; uma orientação espacial que lhe facilite sua movimentação; uma coordenação adequada para compreensão dos conceitos verbais; uma capacidade de simbolização uma estruturação temporal que permite à criança adquirir o ritmo e as seqüências para uma emissão da fala mais fluida. (OLIVEIRA, 1997, p. 108).
\end{abstract}

Dessa forma, percebe-se que a música é algo indispensável na vida do indivíduo, pois exerce uma grande influência em seus aspectos corporais, linguísticos e sentimentais, contribuindo também para uma aprendizagem prazerosa, lúdica e divertida.

\title{
A importante etapa da educação infantil
}

A educação infantil é uma fase primordial na vida das crianças, pois tem o papel de contribuir com a ação da família e da sociedade no seu desenvolvimento e socialização. É nesta etapa que as crianças constroem laços afetivos e têm os primeiros contatos com outras crianças. Assim diz a legislação de $n^{\circ}$ 9394/96 (Lei de Diretrizes e Bases da Educação Infantil):

A educação Infantil, primeira etapa da educação básica, tem como finalidade o desenvolvimento integral da criança até seis anos de idade, em seus aspectos físico, psicológico, intelectual e social, complementando a ação da família e da comunidade. (BRASIL, 1996).

Para tanto, é importante que se reconheça que a criança precisa ser vista como única nas suas necessidades e características, levando em consideração que cada uma tem o seu próprio tempo e modo para desenvolver-se. Além disso, o ambiente educativo precisa ser adequado, seguro, positivamente estimulante e alegre, para que permita a integração dos cuidados com as crianças. Com a organização do espaço adequado a criança poderá desenvolver o seu imaginário com a leitura do ambiente que a mesma está inserida. O Referencial Curricular Nacional para a Educação Infantil diz que 


\begin{abstract}
A organização do espaço físico das instituições de educação infantil deve levar em consideração todas as dimensões humanas potencializadas nas crianças: o imaginário, o lúdico, o artístico, o afetivo, o cognitivo etc. (BRASIL, 1998, p. 58).
\end{abstract}

Ademais, não se pode esquecer que desde essa etapa inicial as crianças começam a formar suas personalidades, a criar laços afetivos e a se socializar com outros e com o meio em que vivem. Assim, uma educação de qualidade, além de proporcionar a aprendizagem, precisa contemplar os interesses e elementos da vivência das crianças, sem negligenciar a leveza e a diversão que a fase da infância supõe.

É nesta direção que a ludicidade se apresenta como importante elemento da educação infantil, visto que proporciona que o aprendizado e o desenvolvimento sejam estimulados de forma mais agradável e natural, permitindo uma forma mais ativa e significativa dentro do ambiente escolar.

Levando em consideração o papel que a ludicidade ocupa na aprendizagem dentro da educação infantil, se faz necessário refletir sobre esses recursos lúdicos que fazem e podem fazer parte do dia a dia das escolas, de modo a aprimorar o seu uso e potencializar o caráter estimulador e ampliador de conhecimentos que esses recursos possuem. Nesse caso, o foco aqui se volta para a musicalidade, o local que ela ocupa e as contribuições que a mesma pode trazer nesta etapa escolar.

\title{
A música na educação infantil
}

Através do levantamento bibliográfico na área em questão, foi possível perceber que inúmeros estudos apontam a contribuição da música na educação infantil, sendo considerada como facilitadora do desenvolvimento e do aprendizado da criança, quando utilizada enquanto mediadora do processo do ensino e aprendizagem. Segundo Gilioli (2008): “A música na educação infantil auxilia no desenvolvimento psicomotor, contribui no processo de socialização e aproxima a criança da arte".

Assim, a música permite estimular as dimensões cognitiva e psicomotora da criança, oferecendo benefícios para o desenvolvimento de habilidades e capacidades.

Faria (2001) ressalta que:

A música como sempre esteve presente na vida dos seres humanos, ela também sempre está presente na escola para dar vida ao ambiente escolar e favorecer a socialização dos alunos, além de 
despertar neles o senso de criação e recreação. (FARIA, 2001, p. 24).

O referido autor destaca também que o uso da música contribui diretamente no meio social e afetivo do indivíduo, permitindo, assim, a ação direta do criar e recriar. Contudo, é importante ressaltar que para alcançar os objetivos propostos a música deve ser utilizada de maneira planejada, adequada e através de atividades bem desenvolvidas, pois se utilizada sem esses cuidados pode perder o seu potencial estimulador e criativo. De acordo com Godoi (2011), atividades mecânicas esvaziadas de sentidos e visando a mera memorização de músicas pode gerar desinteresse e não trazer contribuição para o aprendizado.

Visto que a criança tende a desenvolver-se de acordo com os estímulos recebidos, a música também ajuda a desenvolver a audição, concentração e efeitos sonoros através de diferentes sons. Chirarelli (2005) acrescenta:

Por isso, é fundamental fazer uso de atividades de musicalização que explorem o universo sonoro, levando as crianças a ouvir com atenção, analisando, comparando os sons e buscando identificar as diferentes fontes sonoras. Isso irá desenvolver sua capacidade auditiva, exercitar a atenção, concentração e a capacidade de análise e seleção de sons. (CHIARELLI, 2005, p. 5).

Ainda que o processo de descoberta e de exploração da música seja uma atividade de extrema importância, se feita de maneira isolada, essa prática tende a consistir em uma visão reduzida do olhar do professor, se considerada as diversas práticas pedagógicas que podem ser realizadas com a música. (NOGUEIRA, 2005).

Por fim, vale ressaltar que a lei de número 11.769 altera a LDB (Lei de Ditretrizes e Bases Nacionais), destacando que a musicalização passou a ser prática obrigatória em todas as instituições de ensino, podendo ser trabalhada de diferentes formas como canção, movimentos corporais com música, músicas utilizadas em brincadeiras, músicas e ritmo através de palmas e batidas, com instrumentos musicais, histórias cantadas, alternância de ritmos e estilos de músicas.

\section{METODOLOGIA}

Tendo em vista alcançar os objetivos propostos, o presente estudo foi desenvolvido através da abordagem qualitativa exploratória. De acordo com Ribeiro (2006):

Pesquisar qualitativamente é, antes de qualquer outra definição, respeitar o ser humano em sua diversidade. É 
entender que há singularidade em cada uma das pessoas envolvidas e que essa singularidade é construída na pluralidade; nas múltiplas etnias, nas pluri-manifestações culturais, corporais, lingüísticas. É gostar de ser gente. (RIBEIRO, 2006, p. 40).

Para isso, foi realizado um estudo de campo através da aplicação de entrevistas semiestruturadas. Marconi e Lakatos (2007) ressaltam que nesse tipo de entrevista o pesquisador tem liberdade para desenvolver a situação na direção que considera adequada, explorando mais amplamente o diálogo, visando assim encontrar as respostas pelas quais se procuram.

Nesse sentido, a pesquisa contou com cinco (05) participantes, sendo: três (03) professores que atuam em ciclos diferentes da educação infantil da rede privada de ensino, uma (01) coordenadora que também é professora de inglês em uma escola privada e uma (01) coordenadora de escola privada que também é vice-dirigente da rede municipal. Todos os entrevistados foram analisados para a coleta de dados da pesquisa.

Devido à pandemia da COVID-19, a coleta de dados precisou acontecer de forma virtual, através dos aplicativos "Zoom" e "Google Meet". Os materiais utilizados foram: celular, notebook, roteiro das entrevistas, caderno e lápis para anotações. Assim, as entrevistas foram conduzidas individualmente nos horários escolhidos pelas participantes.

\section{RESULTADOS}

O presente capítulo foi construído a partir da análise dos dados obtidos por meio da pesquisa de campo. As entrevistas realizadas serão aqui discutidas e relacionadas com teoria das áreas em questão, ampliando assim o campo de conhecimento sobre oreferido tema.

Primeiramente, foi possível constatar a concepção das entrevistadas sobre a importância de trabalhar com a música no cotidiano escolar, percebendo na fala das professoras e coordenadoras o impacto que a musicalidade pode causar no processo de desenvolvimento e aprendizagem das crianças, destacando-se a presença da ludicidade nesse processo, proporcionando intervenção e momentos educativos que sem a música não aconteceriam. É possível perceber isso nos seguintes recortes de falas das entrevistadas:

C. R. Ressalta que "A música é tão rica, porque a gente consegue ter 
vários objetivos dentro dela e partindo de uma questão prazerosa de brincadeira. A gente é que sabe, a gente enquanto educador a gente sabe o que está atingindo com aquilo ali, mas a criança não, pra ela, ela está brincando, e aí eu acho que assim é um estímulo, uma questão que ele recebe muita autentico, porque ele está tão preso sabe, eu tenho que aprender aquilo, eu tenho fazer aquilo, e aí eu acredito que o aprendizado entra de uma forma muito gostosa, muito prazerosa, como deveria ser".

G. K. diz: "vejo que influencia muito a questão da oralidade, memorização, que é mais uma questão de estímulos cognitivos mesmo e principalmente a questão com dificuldade na fala, tem criança que não interage."

S. C. afirma que "a música para a educação infantil é básico, é onde a criança se comunica, onde ela explora o vocabulário, ela se expressa corporalmente, ela consegue o contato com o outro."

$\boldsymbol{K}$. L. contribui dizendo que "A musicalidade é importante para esse desenvolvimento não só da linguagem oral, mas a linguagem corporal como um todo. Ela tem tantos significados tanto didático, quanto também no Desenvolvimento Infantil, a questão dessa percepção, dessa brincadeira com a liberação, os jogos poéticos, musicais, até sonoridade mesmo a percepção sonora."

Assim, as entrevistadas concordam que a música é extremamente importante na educação infantil, pois ela trabalha as áreas psicomotoras e cognitivas, melhora a linguagem oral e o gosto musical. A criança desenvolve a percepção auditiva, a destreza, a coordenação motora, fortalece os músculos, ajuda na socialização, estimula a imaginação e a criatividade. Nessa mesma linha, Bréscia (2003) afirma:

\begin{abstract}
O trabalho de musicalização deve ser encarado sob dois aspectos: os aspectos intrínsecos à atividade musical, isto é, inerentes à vivência musical: alfabetização musical e estética e domínio cognitivo das estruturas musicais; e os aspectos extrínsecos à atividade musical, isto é, decorrentes de uma vivência musical orientada por profissionais conscientes, de maneira a favorecer a sensibilidade, a criatividade, o senso rítmico, o ouvido musical, o prazer de ouvir música, a imaginação, a memória, a concentração, a atenção, a auto-disciplina, o respeito ao próximo, o desenvolvimento psicológico, a socialização e a afetividade, além de originar a uma efetiva consciência corporal e de movimentação. (BRESCIA, 2003, p. 15).
\end{abstract}

Além disso, uma das professoras (K. T.) que leciona aulas de inglês, considera a importância da música também para reforçar os conteúdos ensinados, através da prática e da repetição, defendendo que dessa forma fica mais fácil e divertida para as crianças aprenderem a pronúncia das palavras:

K. T. "No meu caso, como professora de lingua inglesa, a gente trabalha muito a questão da repetição, e a forma sintética da língua, no caso a pronúncia, então é fundamental as músicas, todos os dias, geralmente eu faço "hello" com eles com a mesma música ou variando entre uma música e outra, pra que eles possam aprender a pronúncia das palavras." 
Já em relação à análise feita a respeito da utilização da música como forma de auxiliar o processo de desenvolvimento e aprendizagem infantil, foi possível identificar que essa pode contribuir de diversas maneiras, pois influencia na relação professor-aluno, promovendo uma maior socialização e possibilitando que a criança interaja no seu meio social e crie laços afetivos. Conforme se sabe, tal relação é extremamente importante na educação infantil, pois gera um clima de conforto e segurança, o qual garante que crianças se desenvolvam de forma mais plena e saudável.

Ressalta-se também que a música pode auxiliar nesse processo, visto que possibilita a utilização de uma metodologia diferenciada, promovendo uma aula mais lúdica e dinâmica, que estimula a curiosidade do aluno, promovendo a motivação e a criatividade, e assim as crianças aprendem sem nem perceber. Nesse sentido, as professoras têm a mesma visão.

C. R. ressalta: "De tanto eu trabalhar com música, eu percebo o comportamento diferenciado, às vezes na linguagem, às vezes no sorriso. Eu recebo crianças muito apáticas, e eu percebo, por eu gostar muito de música, que essa criança vai aos poucos tirando aquela apatia (...) Uma professora fala muito: teus meninos participam, eles falam, eles conversam. Mas eu acredito que é isso, é aquela música que eu coloco, sabe?"

G. K. diz: "Através da música a gente trabalha o desenvolvimento da criança, uma vez que esses são os referentes, então é estimulando, a música vai trabalhar a estimulação".

C. T. esclarece que "A música desenvolve em todos os fatores, porque além de trabalhar a linguagem, também contribui para o desenvolvimento corporal, [...] então além de trabalhar com eles a fonética do vocabulário eu também estou trabalhando o desenvolvimento motor quando eu peço pra eles pularem, correrem".

S. C. contribui dizendo que "A música consegue trazer essa relação entre professor, entre quem tá interagindo com ela e ele. Ela traz esse elo entre os dois. Então tem uma importância muito grande na aprendizagem sim, com certeza".

Percebe-se, assim, que todas as entrevistadas reconhecem o auxílio para a promoção do desenvolvimento e da aprendizagem. Nesse sentido, Del Ben (2002) destaca que:

A música pode contribuir para a formação global do aluno, desenvolvendo a capacidade de se expressar através de uma linguagem não-verbal e os sentimentos e emoções, a sensibilidade, o intelecto, o corpo e a personalidade [...] a música se presta para favorecer uma série de áreas da criança. Essas áreas incluem a "sensibilidade", a "motricidade", o "raciocínio", além da "transmissão e do resgate de uma série de elementos da cultura". (DEL BEN, 2002, p. 52-53). 
Por fim, no tocante a identificação das formas como a música pode ser inserida na educação infantil, verifica-se que pode acontecer de várias maneiras, não só em momentos pontuais, como em atividades de rotina ou com conteúdos curriculares, mas também trabalhando os sons da natureza, os sons que podemos fazer com o próprio corpo ou com objetos. Duas entrevistadas apontam o seguinte:

K. L. Diz que "Corporalmente falando, a gente tem aí o enriquecimento da questão da mobilidade da criança, da capacidade dela de se mover. Utilizando e fazendo o uso do ritmo ela já vai começar a marcar passos, a contar com palmas, tudo isso é musicalidade e às vezes a gente restringe a música como se fosse algo: "ah vamos escutar aqui a música do Mundo Bita, quando na verdade a sonoridade de muitas coisas, de sons podem se transformar em música [...] a gente precisa mostrar que há compassos que na verdade as crianças podem produzir sons com coisas muito pequenas eque a gente pode ampliar o leque".

C. R. contribui dizendo que "A própria natureza tem isso. A natureza tem música, tem sons, ruídos e muita coisa boa. A gente não entende porque gosta de estar dentro de uma floresta, vamos dizer assim, a gente não entende porque a gente gosta de estar diante do mar, porque é toda aquela musicalidade do mar, de um parque, de você no meio de umas árvores."

Nesse sentido, Maffioletti (2001, p.134) ressalta:

Os métodos de ensino da música mostraram que a educação musical não pode ser promovida apenas por atividades cantadas. Deslocar-se pela sala adequando-se o passo ao andamento da música; as atividades de produção e reprodução de ritmos utilizando o próprio corpo; a execução de instrumentos musicais criados pelas crianças e a criação de pequenas melodias e ritmos também devem fazer parte do planejamento. (MAFFIOLETTI, 2001, p. 134).

Nessa discussão, destaca-se ainda que a música pode ser inserida para proporcionar momentos prazerosos, nos quais o aluno pode ter instantes de terapia e relaxamento. Como ressalta a professora G. K. "É um momento de terapia, quando eu trabalho com algum fundamento, algum tipo de música, faço um momento de relaxamento, apago a luz, deixo eles ficarem bem a vontade."

Porém, o que se observa mais frequentemente é que os professores da educação infantil costumam inserir a música apenas em momentos específicos como lanche, contação de histórias, na hora da acolhida ou apenas em datas comemorativas. Como fica claro na fala de duas entrevistadas:

G. K. Diz: "Trabalho com a música nas horas de lanche, mas eu trabalho as músicas direcionadas".

S. C. ressalta que: “A música na educação é primordial em todos os 
momentos, na hora do lanche, na hora da chegada, na hora da saída, na hora que você vai fazer algum trabalho, em datas comemorativas".

A partir da análise e discussão dos dados acima, foi possível compreender a contribuição da música na educação infantil, potencializando o processo de ensino e aprendizagem dentro do espaço escolar.

Contudo, percebe-se que ainda se faz necessário ampliar os momentos em que ela aparece no contexto escolar, incluindo-a em variadas atividades e, logo, ampliando o leque de contribuição para com a educação infantil.

\section{CONSIDERAÇÕES FINAIS}

A pesquisa desenvolvida aponta que a música pode impactar positivamente no processo de desenvolvimento e aprendizagem das crianças na educação infantil, não só como mediadora da construção de conhecimentos, mas também nas dimensões corporais e socioemocionais. Para tanto, as atividades que envolvem a musicalidade dentro de sala de aula devem ser bem planejadas e executadas, buscando potencializar a capacidade lúdica que ela possui.

Destacamos que, através dos resultados apresentados, foi possível ressaltar a importância da contribuição da música no processo de desenvolvimento e aprendizagem na educação infantil, pois ela pode ser inserida como um agente facilitador em diversos aspectos, podendo ser usada não só na rotina, mas também em conteúdos e momentos de distração, trazendo leveza e fortalecendo o vínculo entre professor e aluno.

Nesse sentido, destaca-se a importância do professor na condução desse processo educativo. O ideal é que a formação desse profissional contemple conhecimentos teóricos e metodológicos que visem garantir a utilização da música da melhor maneira possível, ampliando o leque de atuação nesse espaço educativo.

Ainda que tal discussão já se faça presente há algum tempo no campo teórico, ela precisa ganhar maior notoriedade na prática cotidiana dos profissionais dentro da educação infantil.

Concluímos enfatizando que a música contribui diretamente na educação infantil e em seu desenvolvimento, auxiliando na sensibilidade, na motricidade, e no raciocínio, porém fica como sugestão que sejam realizadas pesquisas sobre esse tema, envolvendo outros participantes, outros contextos, através de outra metodologia, podendo ser realizadas pesquisas dentro de escolas que tivessem um 
olhar mais amplo, tratando do tema sob uma nova perspectiva e uma nova intervenção.

\section{REFERÊNCIAS}

ARRIBAS, Teresa Lleixá. Educação Infantil: Desenvolvimento, Currículo e Organização Escolar. 5. ed. Porto Alegre: Artmed, 2006.

BRASIL. Ministério da Educação. Lei de Diretrizes e Bases da Educação Nacional. Lei n. 9.394/96. Disponível em:

https://www.jusbrasil.com.br/busca?q=Art.\%2029\%20da\%20Lei\%209394\%2F96.

Acesso em: 20 jan. 2021.

BRASIL. Referencial Curricular Nacional para a Educação Infantil. Ministério da Educação e do Desporto. Secretaria de Educação Fundamental. V. 3. Conhecimento de Mundo.

Brasília:

$\mathrm{MEC} / \mathrm{SEF}$,

$$
1998 . \quad \text { Disponivel em: }
$$

https://issuu.com/atomoealinea/docs/educacao_musical. Acesso em: 05 fev. 2021.

BRÉSCIA, V. L. P. Educação Musical: bases psicológicas e ação preventiva. São Paulo: Átomo, 2003.

CHIARELLI. L. K. M. A música como meio de desenvolver a inteligência e a integração do ser. Instituto Catarinense de Pós-Graduação. Revista Recre@rte n. 3 Junho 2005.

DEL BEN, Luciana; HENTSCHEKE, Liane. Educação musical escolar: uma investigação a partir das concepções e ações de três professores de música. Revista da ABEM. Porto Alegre, v.13, 2002.

FARIA, Márcia Nunes. A música, fator importante na aprendizagem. Assischateau briand-Pr, 2001. 40f. Monografia (Especialização em Psicopedagogia).

GÓES, Raquel Santos. A música e suas possibilidades no desenvolvimento da criança e do aprimoramento do código lingüístico. Revista do Centro de Educação a Distância - CEAD/UDESC, Florianópolis, Vol. 2, n. ${ }^{\circ}$ 1, p. 27 - 43 mai. /jun. $2009 . \quad$ Disponível em: http://www.revistas.udesc.br/index.php/udescvirtual/article/view/1932/1504. Acesso em: 02 fev. 2021.

GILIOLI, Renato de S. P. Educação musical antes e depois de Villa-Lobos e os registros sonoros de uma época. Fundação Biblioteca Nacional. Ministério da Cultura. Programa Nacional de Apoio à Pesquisa, 2008.

GODOI, Luiz Rodrigo. A importância da música na educação infantil. Londrina PR. Tese apresentada a Universidade Estadual de Londrina, 2011.

MAFFIOLETTI, Leda de Albuquerque. Práticas musicais na Escola Infantil. Educação Infantil. Pra que te quero? Porto Alegre, v.1, n.1, p.123-134, 2001. 
MARCONI, M. de A.; LAKATOS, E. M. Técnicas de pesquisa. 6. ed. rev. ampl. São Paulo: Atlas, 2007.

MORENO, Gilmara Lupion. Organização do Trabalho Pedagógico na Instituição de Educação Infantil. In: PASCHOAL, Jaqueline Delgado (Org.). Trabalho Pedagógico na Educação Infantil. Londrina: Humanidades, 2007, p. 54-62.

NOGUEIRA, C. M .I. Tendências em Educação Matemática escolar: das relações. Aluno-professor e o saber matemático. In: ANDRADE, D.; NOGUEIRA, C. M. I. org. Educação Matemática e as operações fundamentais. Maringá: EDUEM, 2005.

NOGUEIRA, M. A. A música e o desenvolvimento da criança. Revista da UFG, v. 5, n.2, 2003.

OLIVEIRA, Gislaine de Campos. Psicomotricidade: educação e reeducação no enfoque psicopedagógico. 9. ed. Petrópolis: Vozes, 1997.

RIBEIRO, Antonio de Lima. Gestão de Pessoas. São Paulo: Saraiva, 2006.

UNESCO. Banco Mundial. A criança descobrindo, interpretando e agindo sobre o mundo. Brasília: Fundação Maurício Sirotsky Sobrinho, 2005.

\section{APÊNDICE A - Entrevista semiestruturada com as professoras}

1) Para você, qual a importância da música na Educação Infantil?

2) Você acredita que a música pode contribuir no processo de desenvolvimento e aprendizagem da criança? /De que maneira?

3) A música costuma fazer parte do seu cotidiano escolar dentro da educação infantil? De que forma? Em quais momentos?

4) Você observa benefícios do uso da música no dia a dia da sala de aula? Quais?

5) Você identifica alguma dificuldade para utilização da música no contexto escolar? Quais?

6) Na sua opinião, a música é valorizada no contexto escolar?

7) A música pode ser multidisciplinar? 


\title{
APLICAÇÃO DA ENGENHARIA DE PRODUÇÃO NO DIAGNÓSTICO QUALITATIVO DAS AULAS REMOTAS DURANTE A PANDEMIA
}

\author{
https://dx.doi.org/10.48097/2674-8673.2022n6p03
}

João Carlos Nanes Lima Filho ${ }^{1}$

Lavínia Rayanne Severo da Silva ${ }^{2}$

\begin{abstract}
RESUMO
O ensino superior, assim como a educação no mundo, enfrentou um grande desafio no primeiro semestre do ano de 2020 em decorrência da pandemia de Covid-19 que modificou toda a estrutura da metodologia da educação presencial para uma modalidade remota de emergência. Durante este período algumas instituições de nível superior encararam o grande obstáculo da implementação dos meios digitais em suas aulas. Dentro desse contexto, após um ano nesse novo formato de modalidade de ensino, o presente artigo tem o intuito de trazer um breve diagnóstico e uma comparação sobre as dificuldades dos alunos nessas aulas.
\end{abstract}

Palavras-chave: Modalidades de Ensino. Pandemia. Qualidade. Aulas Remotas. Ensino Superior.

Data de submissão: $16 / 08 / 2021$

Data de aprovação: 22/09/2021

\begin{abstract}
Higher education, as well as education in the world, faced a major challenge in the first half of 2020 as a result of the Covid-19 pandemic that changed the entire structure of the classroom education methodology to a remote emergency mode. During this period, some higher education institutions faced the great obstacle of implementing digital media in their classes. Within this context, after a year in this new teaching modality format, this article aims to provide a brief diagnosis and a comparison of the students' difficulties in these classes.
\end{abstract}

Keywords: Teaching Modalities. Pandemic. Quality. Remote Lessons. University education.

\section{INTRODUÇÃO}

No primeiro semestre de 2020 o mundo deparou-se com a pandemia provocada pelo Coronavírus ou COVID-19. Os países e governos enfrentaram um desafio único com suas populações: o distanciamento social. Nesse contexto, as Instituições de Ensino Superior - IES

\footnotetext{
${ }^{1}$ Docente orientador do curso de Engenharia de Produção da Faculdade Metropolitana da Grande Recife. E-mail: joaonanes@metropolitana.edu.br

2 Discente do curso de Engenharia de Produção da Faculdade Metropolitana da Grande Recife.

E-mail: la.laraya@hotmail.com
} 
tiveram que suspender as atividades presenciais baseadas nos decretos dos governos estaduais e municipais, determinando a quarentena e sua reclusão em massa. Para que os estudantes não ficassem desassistidos durante o ano de 2020 as IES particulares e públicas recorreram ao modelo de ensino a distância $(\mathrm{EaD})$, na modalidade remota emergencial, de acordo com orientações estabelecidas pelo Ministério da Educação - MEC, constantes no decreto $343 / 2020$.

Este artigo passou por duas fases: a primeira ocorreu durante o mês de março a junho de 2020 quando foi elaborado o primeiro questionário no qual foram coletados dados sobre qual aplicativo de web conferência obteve maior adesão dos estudantes em participação e, no decorrer desse semestre, a instituição superior privada X passou pela transição dos aplicativos e plataformas de web conferência para a realização das aulas. Após um mês de testes semanais foi instituído pela IES X o aplicativo Google Meet como padrão para a aplicação da metodologia de ensino emergencial remoto.

A segunda fase do artigo formou-se a partir da coleta de dados por meio do aplicativo Survey Monkey com 50 alunos de uma instituição superior privada, localizada em Pernambuco, que fez a aplicação das suas aulas através da modalidade remota emergencial com embasamento jurídico na lei $n^{\circ}$ 14.040/2020 aos quais as IES obtêm um suporte para a realização das aulas até o final da pandemia e com o auxílio das Tecnologias Digitais da Informação e Comunicação - TDIC's, assistindo os alunos durante este período.

A pesquisa teve como objetivo fazer um comparativo sobre os impactos qualitativos e quantitativos com relação ao primeiro ano da pandemia nesta instituição de ensino superior e no semestre letivo do ano de 2021.1, obtendo, por meio de um questionário (que ficou aberto durante o período de abril de 2021 até o final do mês de maio do mesmo ano), uma avaliação da qualidade do ensino pela ótica dos alunos da IES. Esta avaliação foi usada como objeto de estudo, apresentando uma análise voltada para estabelecer indicadores de qualidade na nova metodologia de ensino superior que estava sendo aplicada durante a pandemia no estado de Pernambuco.

\section{ENSINO SUPERIOR BRASILEIRO}

$\mathrm{O}$ ensino superior no Brasil ocorreu tardiamente, iniciando-se durante o século XX em meados das décadas de 20 e 30 quando foram inseridas as primeiras instituições com cursos de graduação, mestrado e doutorado e depois de um período de tempo foram criadas as primeiras faculdades de ensino privado. 
Logo surgiu a Associação Brasileira de Mantenedoras de Ensino Superior - ABMES que teve início da década de 80 e foi criada com o intuito de representar nacionalmente a categoria e lutar por seus direitos que estão garantidos na Constituição Federal. (ECKEERT, CLARISSA; BENEDITO, CARLOS, 2002, p. 96).

\section{Ensino Presencial}

A modalidade de ensino presencial é a mais comum no território brasileiro em todos os níveis da educação, desde o fundamental ao superior. A mesma se caracteriza por ter um ambiente físico para a realização e aplicações das aulas, onde docentes e discentes se reúnem, utilizando-se de materiais físicos de apoio, sendo os conhecimentos efetivados por meio de trabalhos, avaliações e debates. (BATES, 2017).

\section{Ensino a Distância}

O Ensino a distância $(\mathrm{EaD})$ aplica-se ao aluno que está estudando sem estar presente fisicamente em uma sala de aula tradicional, cujo método proporciona maior flexibilidade de horário, economia, comodidade e inovação. Através da tecnologia é possível formar profissionais por todo o mundo, pois o estudante tem total independência de horários e organização dos seus assuntos, sendo as atividades gravadas e postadas antecipadamente nas suas respectivas plataformas. (MEC, 2007).

\section{Ensino Remoto}

A modalidade remota tem como característica principal o estudo com flexibilidade de local e com fácil acesso à plataforma, porém com um horário específico das aulas definido na matrícula do estudante. As mesmas acontecem online e em tempo real. Os professores, através de aparatos tecnológicos, exibem as suas aulas, aplicam as atividades, e os alunos apresentam as suas dúvidas que são respondidas simultaneamente. Esta modalidade conta com materiais atualizados e aulas dinâmicas, seguindo o cronograma instituído pela IES contratada pelo discente. (CARVALHO; CUNHA; QUIALA, 2020). 
Figura 1 - Diferenças entre as aulas de Educação a Distância (EaD) e Aulas Remotas

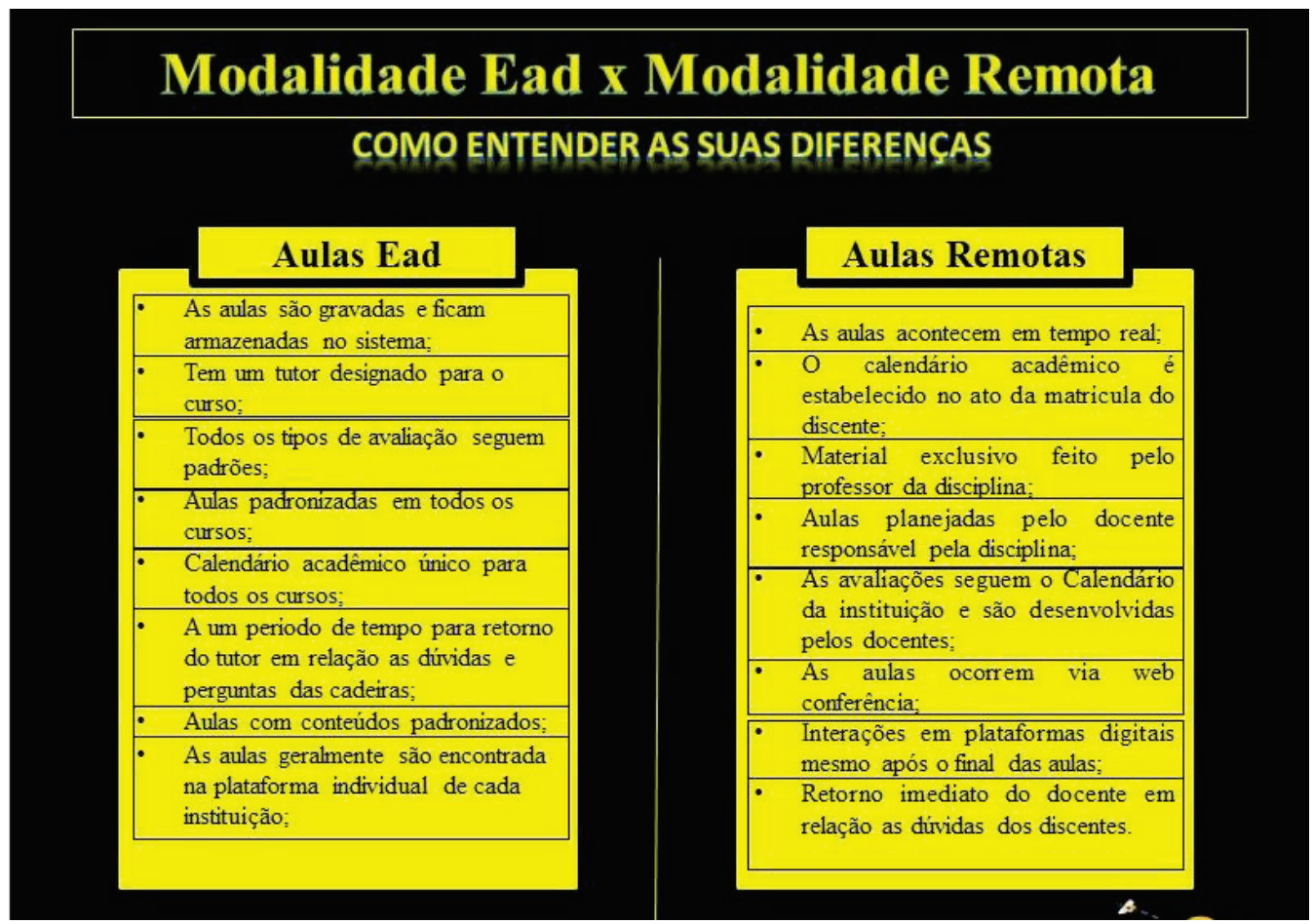

Fonte: Adaptado de Rededeensinojk, 2020.

No ano de 2020, durante o primeiro semestre, tornou-se necessário o isolamento social e o Ministério de Educação - MEC forneceu o apoio jurídico para dar continuidade a essas aulas com a portaria de $\mathrm{n}^{\mathrm{o}} 343$ do dia 17 de março de 2020 .

O MINISTRO DE ESTADO DA EDUCAÇÃO, no uso da atribuição que lhe confere o art. 87, parágrafo único, incisos I e II, da Constituição, e considerando o art. $9^{\circ}$, incisos II e VII, da Lei $\mathrm{n}^{\circ} 9.394$, de 20 de dezembro de 1996 , e o art. $2^{\circ}$ do Decreto $n^{\circ} 9.235$, de 15 de dezembro de 2017, resolve: Art. $1^{\circ}$ Autorizar, em caráter excepcional, a substituição das disciplinas presenciais, em andamento, por aulas que utilizem meios e tecnologias de informação e comunicação, nos limites estabelecidos pela legislação em vigor, por instituição de educação superior integrante do sistema federal de ensino, de que trata o art. $2^{\circ}$ do Decreto $\mathrm{n}^{\circ} 9.235$, de 15 de dezembro de 2017. $\S 1^{\circ} \mathrm{O}$ período de autorização de que trata o caput será de até trinta dias, prorrogáveis, a depender de orientação do Ministério da Saúde e dos órgãos de saúde estaduais, municipais e distrital. $\S 2^{\circ}$ Será de responsabilidade das instituições a definição das disciplinas que poderão ser substituídas, a disponibilização de ferramentas aos alunos que permitam o acompanhamento dos conteúdos ofertados bem como a realização de avaliações durante o período da autorização de que trata o caput. (ABMES, 2020).

Devido às medidas de prevenção ao contágio do Coronavírus a quarentena permaneceu ativa e as aulas presenciais seguiram suspensas. Com embasamento na lei 14.040/2020 e 
supervisão do Conselho Nacional de Educação - CNE, as IES receberam autorização para realização das aulas remotas até dezembro de 2021.

Faço saber que o Congresso Nacional decreta e eu sanciono a seguinte Lei: Art. $1^{\circ}$ Esta Lei estabelece normas educacionais a serem adotadas, em caráter excepcional, durante o estado de calamidade pública reconhecido pelo Decreto Legislativo $\mathrm{n}^{\circ} 6$, de 20 de março de 2020. Parágrafo único. O Conselho Nacional de Educação (CNE) editará diretrizes nacionais com vistas à implementação do disposto nesta Lei. Art. $3^{\circ}$ As instituições de educação superior ficam dispensadas, em caráter excepcional, da obrigatoriedade de observância do mínimo de dias de efetivo trabalho acadêmico, nos termos do caput e do $\S 3^{\circ}$ do art. 47 da Lei $\mathrm{n}^{\circ} 9.394$, de 20 de dezembro de 1996, para o ano letivo afetado pelo estado de calamidade pública referido no art. $1^{\circ}$ desta Lei, observadas as diretrizes nacionais editadas pelo $\mathrm{CNE}$ e as normas a serem editadas pelos respectivos sistemas de ensino, desde que: I seja mantida a carga horária prevista na grade curricular para cada curso; e II - não haja prejuízo aos conteúdos essenciais para o exercício da profissão. $\S 1^{\circ}$ Poderão ser desenvolvidas atividades pedagógicas não presenciais vinculadas aos conteúdos curriculares de cada curso, por meio do uso de tecnologias da informação e comunicação, para fins de integralização da respectiva carga horária exigida.

\section{Qualidade de Serviços}

A qualidade de serviços pode ser gerenciada com base nas dimensões em que se percebe confiabilidade, capacidade de prestar os serviços prometidos com confiança e exatidão, responsabilidade, disposição para auxiliar o cliente e oferecer uma prestabilidade, ou seja, superar qualquer expectativa de atendimento e prestação do que foi oferecido.

A qualidade tem um conceito subjetivo, pois se mantém diretamente ligada ao produto ou serviço oferecido ao cliente, por isso não se torna possível limitar a definição dessa palavra. Logo, ela transcende do fato de ser fabricado um bom produto ou executar um serviço padronizado e planejado. Durante a Primeira e a Segunda Guerra Mundial, em meados das décadas 1930 nos Estados Unidos, e 1940 no Japão, surgiram alguns métodos e aplicações reais da caracterização da qualidade. Alguns creem que a qualidade é a adequação ao uso, já outros trazem um conceito ocidental de que a qualidade se baseia em produtos e serviços que atendem ou excedem as expectativas do consumidor. Portanto, a qualidade não é só a realização de um serviço ou produção de um produto, mas também um estado de espírito para aqueles que vão consumi-los. (JURAN; NIORAKI KANO; 2015).

Durante os anos 1950 as empresas começaram a notar que a qualidade estava diretamente ligada à lucratividade, por isso elas iniciaram modelos de padronização para uma melhor conformidade dos produtos, adotando métodos de análise qualitativa no processo. "A gestão da qualidade total, como ficou conhecida essa nova filosofia gerencial, marcou o 
deslocamento da análise do produto ou serviço para a concepção de um sistema da qualidade". (CARVALHO; NASCIMENTO; MORAIS, 2010).

\section{Métodos de Análise e Solução de Problemas - MASP}

O Método de Análise e Solução de Problemas - MASP possui oito etapas: identificação do problema; observação; análise; plano de ação; ação; verificação; padronização e conclusão. Isso contribui para a identificação precisa da anomalia de qualquer processo, obtendo um feedback positivo, seja por uma ação corretiva ou minimizadora do problema. Esse sistema fornece um subsídio para a elaboração de análise e priorização dos problemas, situando a gestão e a equipe onde realmente se precisa de uma atenção mais aguçada no projeto, tendo uma melhoria contínua e padronizando os métodos.

Figura 2 - Método de Análise e Solução de Problemas e PDCA

\begin{tabular}{|c|c|c|c|}
\hline PDCA & FLUXOGRAMA & FASE DO MASP & OBJETIVO \\
\hline \multirow{4}{*}{$\mathbf{P}$} & & Identificação do problema & Definir o problema e verificar sua importância. \\
\hline & & Observação & Investigar as características do problema. \\
\hline & & Análise & Descobrir as causas fundamentais. \\
\hline & & Plano de Ação & Conceber um plano para as causas fundamentais. \\
\hline D & & Execução & Aplicar o plano para bloquear as causas. \\
\hline \multirow{2}{*}{ C } & & Verificação & Verificar se o bloqueio foi efetivo. \\
\hline & & \multicolumn{2}{|l|}{ Bloqueio foi efetivo? } \\
\hline \multirow{2}{*}{ A } & & Padronização & Prevenir contra o reaparecimento do problema. \\
\hline & & Conclusão & Recapitular o processo de solução de problemas para trabalhos futuros. \\
\hline
\end{tabular}

Fonte: Campos, 2009

A primeira fase consiste na identificação do problema, levando em consideração o histórico dessas complicações e a frequência em que elas ocorrem; o segundo momento, conhecido como observação, é a descoberta das características desses problemas através de uma coleta de dados e logo após é formado um cronograma de metas para investigar as suas causas. A terceira etapa, a análise, tem como objetivo principal determinar as causas fundamentais, sendo possível observar se o distúrbio no processo acontece nos mesmos horários ou dias, por exemplo, investigando quais são as peculiaridades do problema. $\mathrm{O}$ 
próximo passo traz um plano de ação com planejamento corretivo para a anomalia com uma ferramenta auxiliar da qualidade. Todo esse ciclo faz parte do plan do ciclo PDCA - P (Plan/Planejamento).

A $5^{\mathrm{a}}$ etapa do MASP é a ação, ou seja, o momento de executar as primeiras quatro fases do método de análise e solução de problemas, o que corresponde ao período D (Do/Execução). Por meio de uma nova verificação é confirmada a eficácia do planejamento e prática para correção dos problemas conhecido como C (Check/ Verificação), e por último a padronização do processo e a continuidade do ciclo PDCA A (Action/Ação), recapitulando a solução para os problemas futuros.

A Metodologia de Análise e Solução de Problemas (MASP) é uma forma estruturada de analisar e solucionar problemas da rotina diária das organizações, também conhecida como QC Story, oriunda do movimento da Qualidade Total no Japão. Trata-se de um desdobramento do método gerencial intitulado Ciclo PDCA - P (Plan/Planejamento), D (Do/Execução), C (Check/ Verificação) e A (Action/Ação), idealizado por Shewhart e divulgado por William Edwards Deming. Segundo Campos (2009), o PDCA permite criar, aprender, copiar e difundir conhecimentos, sendo o aprendizado a alma de sua utilização, transformando a organização numa escola, pois a busca por resultados melhores é paralela à busca do conhecimento. (Escola Nacional de Educação Pública - ENAP, 2015).

Figura 3 - Descrição do ciclo PDCA

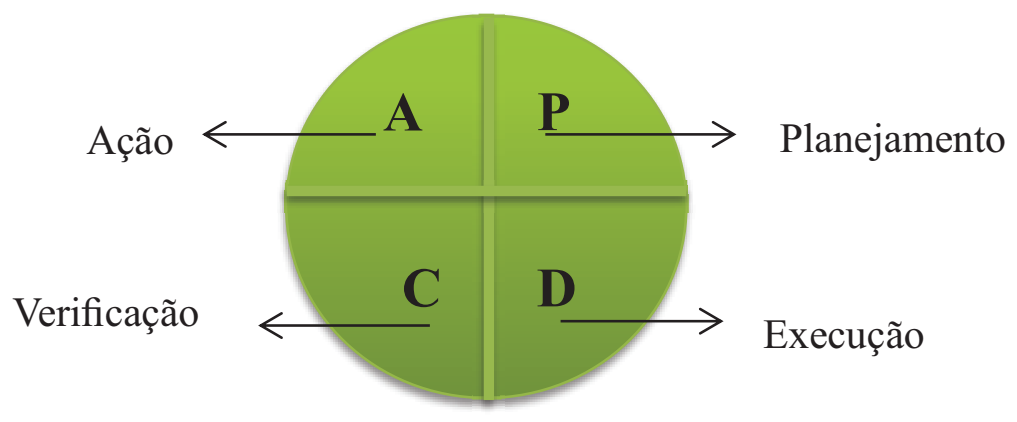

Fonte: Autoria própria

\section{Diagrama de Ishikawa}

O Diagrama de Ishikawa de causa e efeito ou escama de peixe, como é conhecido, foi criado na década de 60 por Karou Ishikawa. Essa ferramenta da qualidade proporciona uma avaliação por meio de gráficos das causas iniciais de um problema antes dele atingir uma proporção maior de efeitos negativos no processo. Esse método tem duas vertentes de solução: a identificação dos problemas, por meio de uma anomalia existente, e um 
levantamento sistemático, ou seja, é feito uma arrumação das causas para visualizar a melhor resolução no processo.

Figura 4 - Descrição do Diagrama de Ishikawa

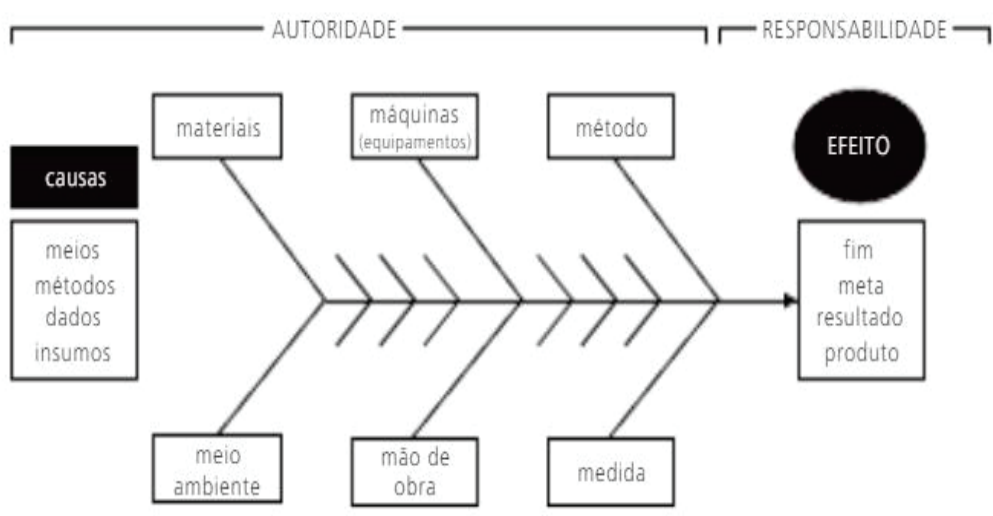

Fonte: Seleme \& Stadler, 2012.

\section{Brainstorming}

O Brainstorming ou "tempestade de ideias", como é conhecido, é um formato de geração de ideias em grupo com o intuito de estimular e incentivar a criar soluções. Com uma dinâmica de reuniões entre grupos, proporciona à empresa um conjunto de ideias inovadoras de forma criativa através do compartilhamento verbal durante os encontros, possibilitando debates e ajustes em todas as sugestões durante o processo. (TOMAZ et al., 2015).

\section{METODOLOGIA}

Este estudo se baseia em uma pesquisa realizada pelo aplicativo Survey Monkey com o objetivo de obter resultados qualitativos e quantitativos, fazendo, assim, um comparativo entre as coletas de dados do questionário que foi aplicado em março de 2020, o qual proporcionou a primeira análise do período de transição da metodologia do ensino presencial para o remoto emergencial. Em paralelo, o segundo questionário traz um comparativo de um ano após a implementação dessa modalidade de ensino acadêmico nas instituições superiores, explanando a perspectiva dos discentes na eficiência das aulas, cujo questionário foi aplicado em abril de 2021, com um tempo médio de resolução de cinco minutos.

Com as TDIC's - (Tecnologias Digitais de Informação e Comunicação) e o modelo da ferramenta MASP da área de qualidade foi feita a coleta dos dados para diagnosticar quais eram as principais dificuldades dos 50 alunos que se propuseram a responder as indagações, além da utilização do brainstorming (técnica para estimular a contribuição espontânea de 
ideias) para promover um comparativo de qualidade das aulas remotas no período de transição e no primeiro semestre de 2021.

Figura 5 - Descrição das quatro etapas trabalhadas no ciclo MASP através do fluxograma

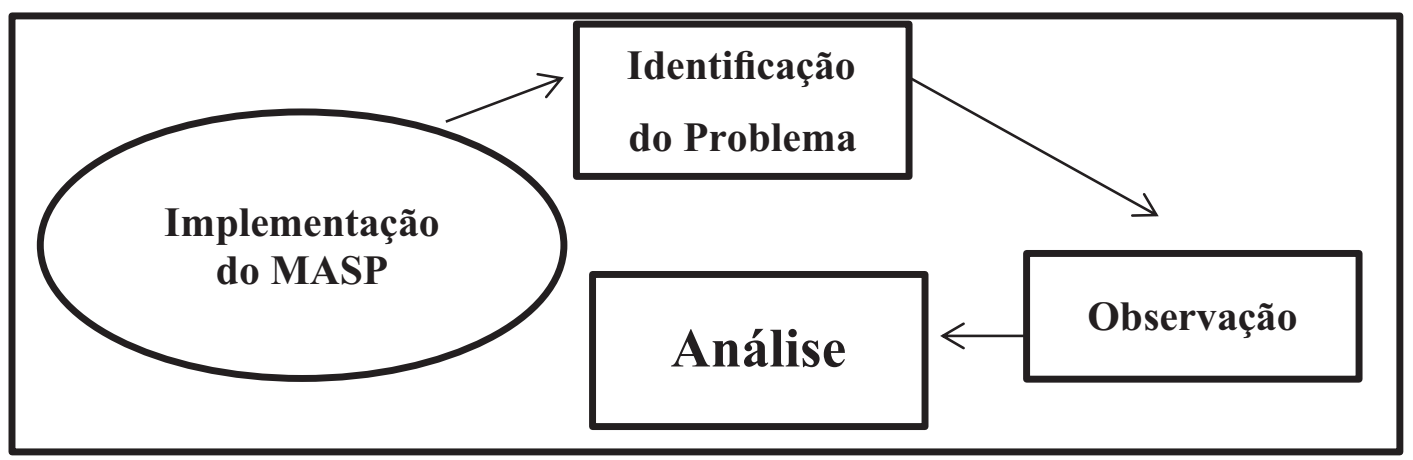

Fonte: Autoria própria

\section{Estudo de Caso}

A primeira etapa (figura 6) consistiu na coleta de respostas das questões: qual ponto de melhoria é crucial nas aulas EaD ou na modalidade remota? Qual a sua sugestão de aprimoramento? Houve uma boa adesão de retorno dos estudantes, sendo elaborado um brainstorming com as sugestões deles sobre as causas fundamentais das anomalias nas aulas remotas e $\mathrm{EaD}$, possibilitando a criação do diagrama de Ishikawa (Figura 7). Foi proposta a sistematização do problema e sua resolução através das suas respostas. Abaixo temos uma figura apresentando alguns pontos que foram abordados pelos estudantes.

Figura 6 - Feedback dos estudantes da IES

\begin{tabular}{|l|l|}
\hline \multicolumn{2}{|c|}{$\begin{array}{c}\text { QUAL PONTO DE MELHORIA É CRUCIAL NO PROCESSO DA MODALIDADE } \\
\text { EaD E MODALIDADE REMOTA? }\end{array}$} \\
\hline \multicolumn{2}{|c|}{ QUAL A SUA SUGESTÃO DE APRIMORAMENTO? } \\
\hline RESPOSTAS & DATAS \\
\hline Material de apoio. & $14 / 07 / 202018: 45 \mathrm{~h}$ \\
\hline Aplicativos mais viáveis, que não travem tanto. & $09 / 02 / 202014: 28 \mathrm{~h}$ \\
\hline Padronização. & $01 / 07 / 2020 \quad 00: 13 \mathrm{~h}$ \\
\hline $\begin{array}{l}\text { A realização dos cálculos em um quadro } \\
\text { durante as aulas. }\end{array}$ & $13 / 07 / 2020 \quad 20: 19 \mathrm{~h}$ \\
\hline $\begin{array}{l}\text { A flexibilidade dos docentes em alguns pontos } \\
\text { durante as aulas. Em questão do sistema um } \\
\text { padrão único de plataforma. }\end{array}$ & $13 / 07 / 202018: 25 \mathrm{~h}$ \\
\hline A atualização das aulas gravadas no portal. & $14 / 07 / 202018: 13 \mathrm{~h}$ \\
\hline A falta de organização das informações. & $14 / 07 / 202018: 10 \mathrm{~h}$ \\
\hline
\end{tabular}

Fonte: Autoria própria 
De acordo com os dados coletados foi produzido o diagrama de Ishikawa ou gráfico de causa e efeito (Figura 7), descrevendo as principais causas das dificuldades dos discentes durante a aplicação das aulas remotas emergenciais. O questionário obteve a participação efetiva de alunos dos cursos de Engenharia de Produção (46\%), Direito (34\%), Pedagogia $(12 \%)$ e Logística $(8 \%)$.

Figura 7 - Diagrama de Ishikawa identificando as principais causas de anomalias

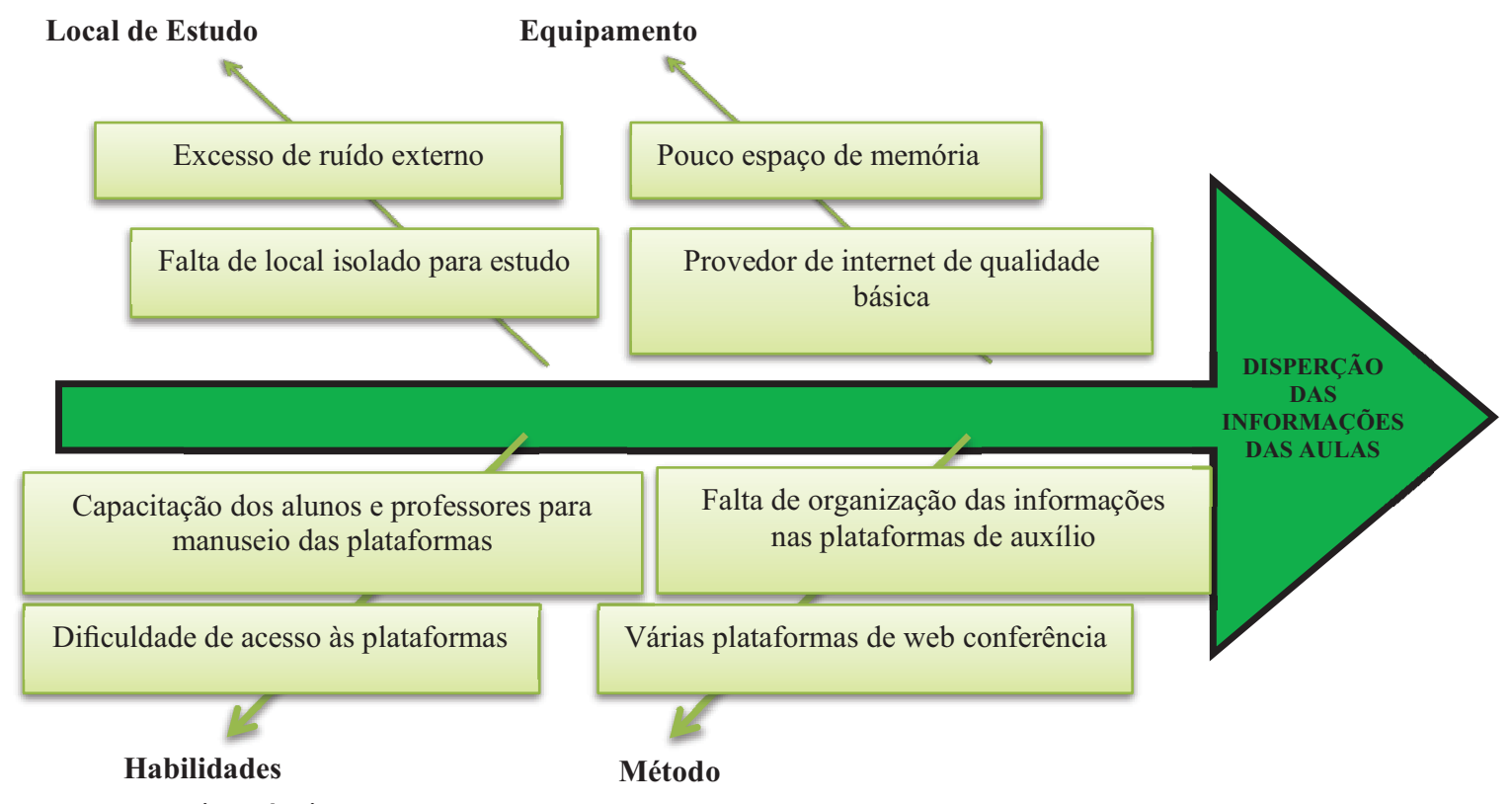

Fonte: autoria própria

Acima, o gráfico de Ishikawa descreve as principais causas que corroboram para a dispersão da informação: capacitação dos docentes e discentes para o manuseio da plataforma de web conferência no período de transição; a falta de organização das informações na plataforma oficial da instituição; o excesso de ruído no local de estudo, causando interrupções; a variedade de aplicativos para assistir as aulas remotas, provocando transtorno de acesso nos momentos de aula, tendo como uma consequência atrasos e perda de assuntos das respectivas matérias. A habilidade de manuseio com os equipamentos de acesso utilizados obteve respostas das aptidões dos estudantes da IES como básica (12,73\%), média (61,82\%) e avançada $(25,45 \%)$.

Após o diagrama de Ishikawa foram criados grupos no aplicativo de troca de mensagem WhatsApp para estabelecer um local específico para a publicação de informações referentes a cada disciplina (Figura 8) e de fácil acesso por parte do estudante, possibilitando o maior engajamento dos alunos durante as aulas e, consequentemente, melhorando o desenvolvimento deles no manuseio das plataformas como Google Meet e Classroom. 
O Grupo no WhatsApp continha as seguintes informações: link do drive onde é armazenado o material de apoio, segregado por disciplina; as gravações das aulas nas plataformas de web conferência; o endereço por link do grupo com o intuito de obter maior engajamento dos discentes; o ID da turma criada pelo professor no aplicativo Classroom; a senha de ingresso para o aluno acompanhar as atividades pendentes e enviá-las no prazo estipulado pelo professor; e por fim o link da aula no aplicativo de web conferência (Figura $8)$.

Figura 8 - Grupo criado com as instruções necessárias para a participação dos discentes nas aulas

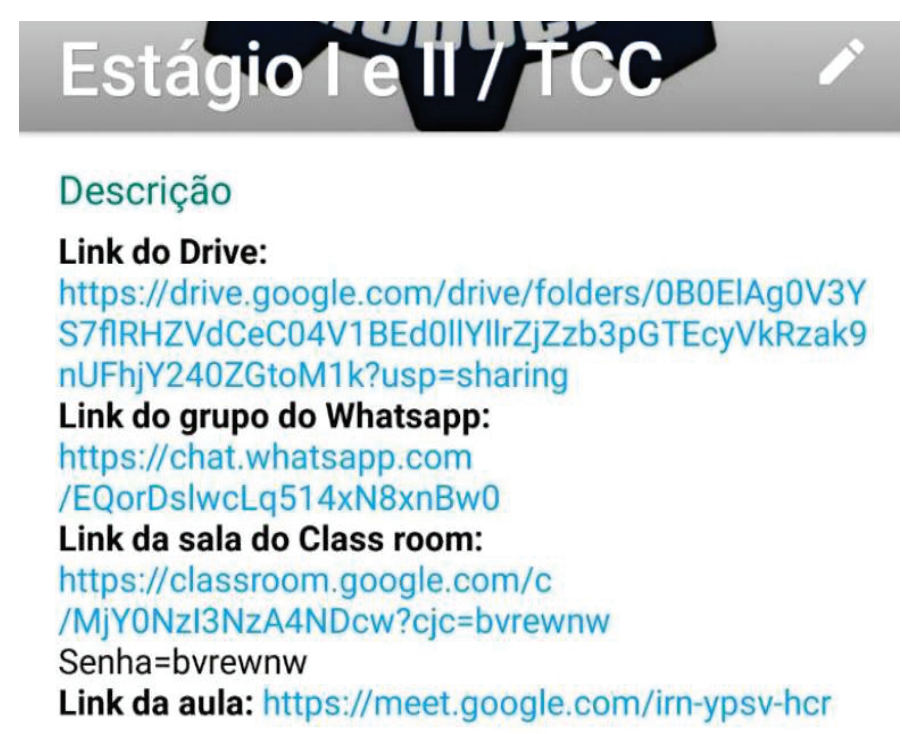

Fonte: Whatsapp, 2021

A plataforma de web conferência que mais obteve aceitabilidade pelos discentes nas duas pesquisas foi o Google Meet devido à facilidade e praticidade de acesso (Figura 9). O mesmo permite ao docente marcar reuniões com seus alunos em formato de agenda e proporciona a explanação do material expositivo (apresentações em slides) com mais facilidade. A figura 09 faz uma comparação com a figura 10 em relação à popularidade dos aplicativos de web conferência que foram testados durante o período de transição das aulas presenciais para a modalidade remota emergencial. 
Figura 9 - Gráfico das plataformas utilizadas para aplicação das aulas remotas em 2020.1 Qual a plataforma que você utiliza para estudar na modalidade remota?

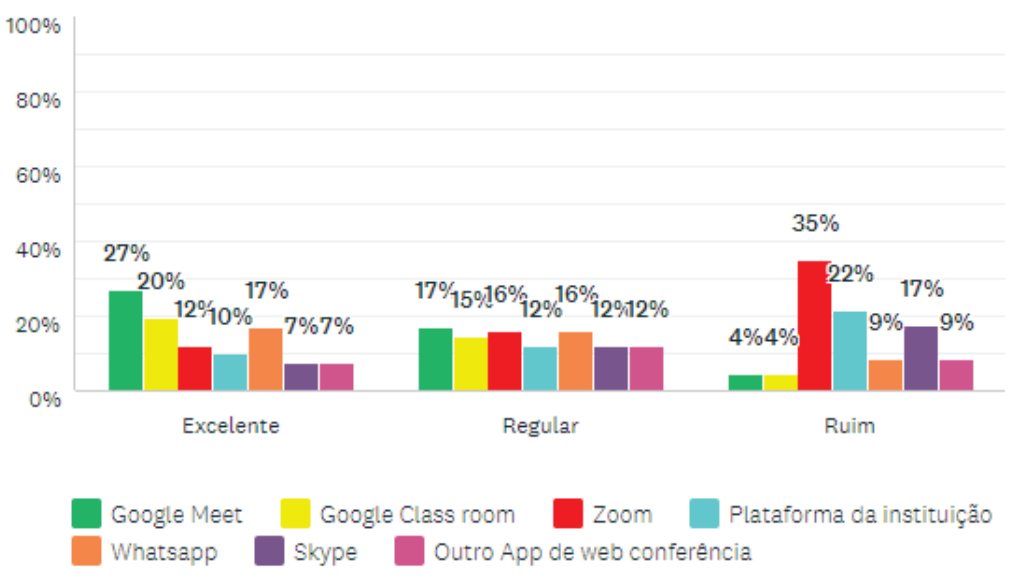

Fonte: Survey Monkey, 2020

De acordo com o feedback apresentado (figura 11) na segunda pesquisa nota-se que depois da transferência de uma modalidade para outra, dentro de um semestre, os discentes identificaram que o aplicativo que mais atendia as suas necessidades de praticidade no acesso à plataforma, agendamento e gravações das aulas era o aplicativo Google Meet. O primeiro gráfico refere-se ao período de implementação e transição das plataformas de web conferência na instituição.

Figura 10 - Gráfico da porcentagem das plataformas utilizadas para aplicação das aulas remotas em 2021.1

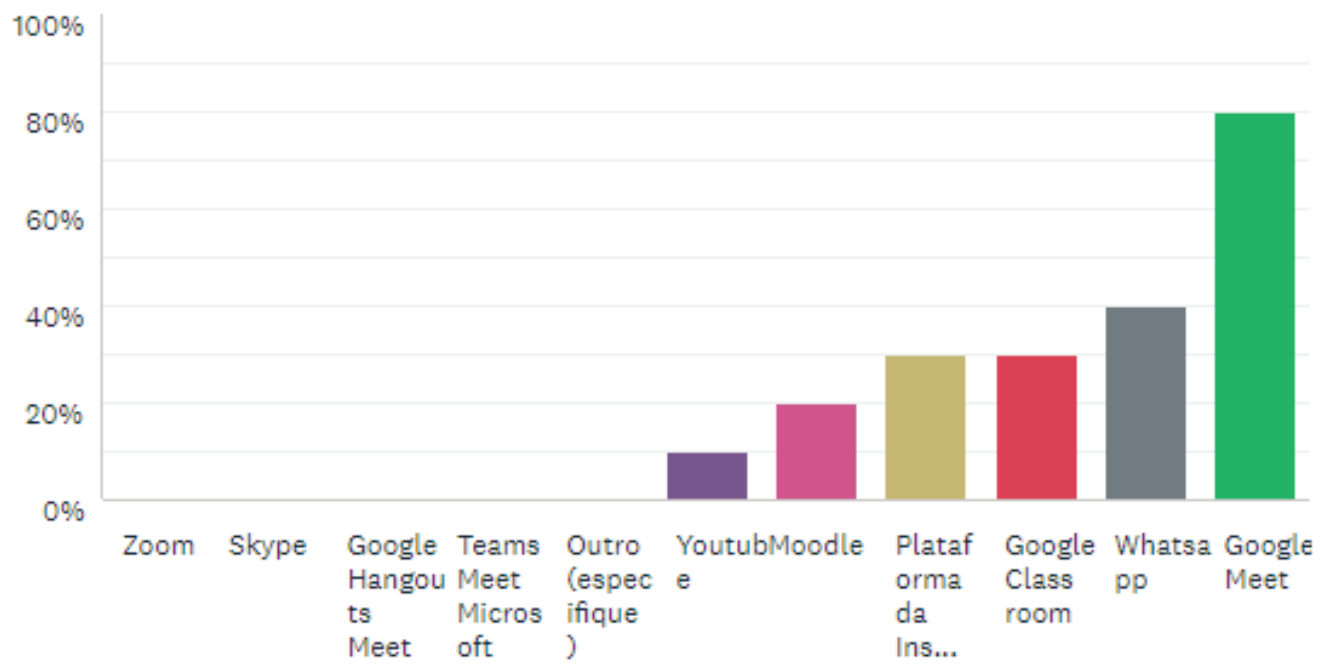

Fonte: Survey Monkey, 2020. 
Com as plataformas Zoom e Google Classroom ocorreram as primeiras tentativas para a realização das aulas remotas, porém, de acordo com um grupo de $20 \%$ dos estudantes, não foi aprovada a qualidade do aplicativo Zoom. Logo em seguida a instituição colocou em teste o aplicativo Google Meet e obteve uma resposta positiva por parte dos alunos, tornando o modelo de web conferência para a apresentação das aulas.

Figura 11 - Gráfico das duas plataformas online que os discentes mais se adaptaram no semestre de 2021.1

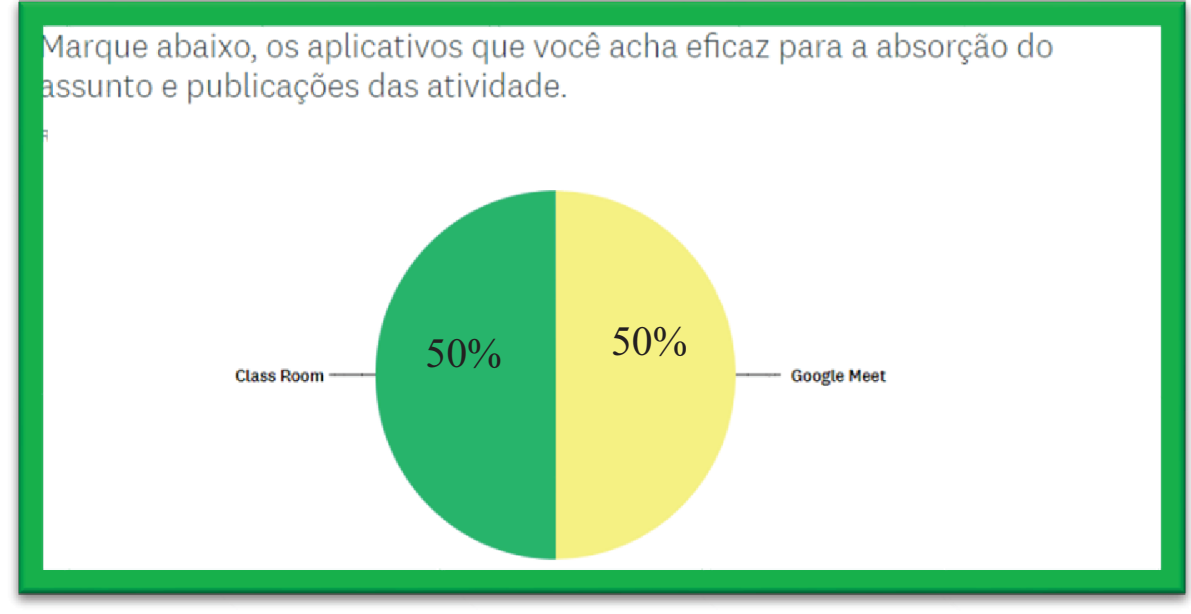

Fonte:_Survey Monkey, 2021

Foi aplicada a última fase da pesquisa, que corresponde à terceira etapa do método PDCA (a verificação), com aplicação de grupos em aplicativos de troca de mensagens, fixação do mural de informações para o acompanhamento e maior engajamento dos alunos durante as aulas, e padronização da plataforma de web conferência. É notório, de acordo com a pesquisa, que a IES possui um índice de melhoria nas aulas remotas devido a identificação dessas anomalias no processo e um feedback dos discentes em relação à qualidade das aprendizagens aplicadas durante o primeiro semestre de 2021. (Figura 12).

O Gráfico abaix o mostra que uma porcentagem de $60 \%$ dos alunos se adaptaram bem e $40 \%$ ainda estavam se adequando ao novo método de ensino EaD remoto. 
Figura 12 - Gráfico sobre a adaptação à modalidade de ensino remoto e EaD que os discentes mais se adequaram no semestre de 2021.1

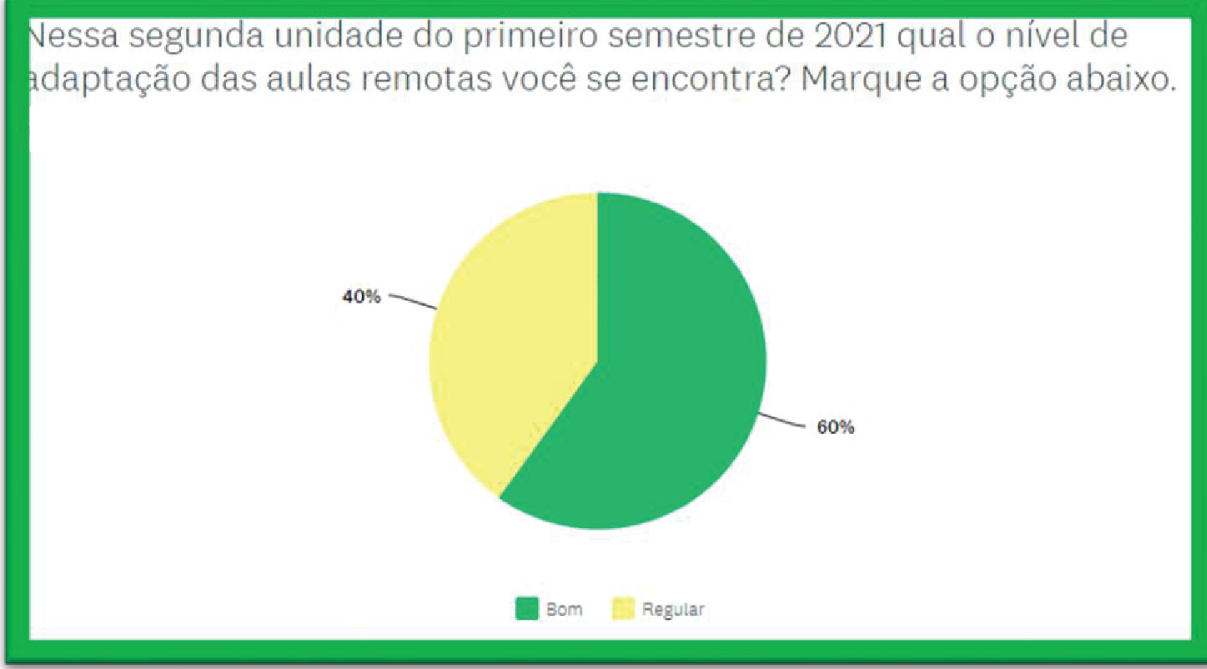

Fonte: Survey Monkey, 2021

\section{CONSIDERAÇÕES FINAIS}

Devido às circunstâncias da pandemia não foi possível uma participação mais ampla na pesquisa com todas as turmas da instituição, porém com bases nos dados apresentados durante o artigo, concluiu-se uma análise qualitativa e quantitativa sobre os níveis de adaptação do ensino presencial para a transição das metodologias remotas e $\mathrm{EaD}$, observando que mais alunos estão engajados de forma participativa e efetiva nas aulas, o que possibilitou respostas mais diretas de acordo a realidade nas salas virtuais dos discentes de ensino de nível superior.

\section{REFERÊNCIAS}

ABED. Ensino a distância e cursos online: conheça as modalidades. Disponível em: http://abed.org.br/blog/modalidades-ead-cursos-online/. Acesso: 5 Jul. 2020.

ABMES. Aulas remotas ou EaD? Disponível em: https://abmes.org.br/noticias/detalhe/3705/aulas-remotas-ou-ead-. Acesso: 12 Jun. 2020.

ARIOLI, E. E. Análise e Solução de Problemas - O Método da Qualidade Total com Dinâmica de Grupo. Rio de Janeiro: Qualitymark, 1998.

CAMPOS, Vicente Falconi. TQC: Gerenciamento da Rotina do Trabalho do Dia a Dia. Rio de Janeiro: 1994.

CARPINETE, L. C. R. Gestão da Qualidade: Conceitos e Técnicas. São Paulo: Atlas S. A, 2010. 
ECKEERT, Clarissa; BENEDITO, Carlos. Ensino Superior no Brasil: uma visão abrangente. p. 96-100, Brasília, 2002.

LAS CASAS, A. L. Qualidade total em serviços. 6. ed. São Paulo: Atlas, 2008.

SELEME, Robson; STADLER, Humberto. Controle da Qualidade: As Ferramentas Essenciais. Curitiba: XIBPEX, 2012.

TOMAZ, Gustavo; TEZA, Pierry; APARECIDA, Gertrudes; SOUZA, João; Métodos, Técnicas e Ferramentas para Inovação: Brainstorming no Contexto da Inovação. 2015. 


\title{
COMPORTAMENTO HUMANO NAS ORGANIZAÇÕES: DESAFIOS FRENTE ÀS MUDANÇAS ENTRE OS PROFISSIONAIS DE UM CALL CENTER
}

\author{
https://dx.doi.org/10.48097/2674-8673.2022n6p04
}

\author{
Arandi Maciel Campelo ${ }^{1}$ \\ Isis Luiza Gomes da Silva ${ }^{2}$ \\ José Felipe da Silva Pereira ${ }^{3}$ \\ Josiane Maria Gomes Calado ${ }^{4}$ \\ Wilson Reis de Alcântara ${ }^{5}$
}

\section{RESUMO}

Este artigo procurou investigar o comportamento humano em uma empresa com intervalo variável de 4 turnos. Alguns trabalhadores foram expostos a condições que traziam o desânimo na equipe, fazendo com que as pessoas deixassem de produzir, muitas vezes por falta de comunicação, pois há gestores que não sabem se impor com tal cargo. A pesquisa bibliográfica teve como principal balizador Chiavenato $(2005 ; 2019)$. O propósito deste artigo é esclarecer para as pessoas a estarem sempre motivadas em seu trabalho, contribuindo para que todos os participantes possam trabalhar e ser feliz, podendo identificar as vantagens que a motivação oferece para as empresas de Call Center, analisando as inúmeras formas de utilização para a melhoria do ambiente de trabalho. A pesquisa de campo, realizada na empresa Neobpo, em 2021, foi de natureza qualitativa e propositiva, tendo como principal instrumento de coleta de dados o questionário. Os dados de campo demonstraram que mesmo muitas vezes as pessoas tem medo de demostrar o que pensa.

Palavras-chave: Comportamento humano nas organizações. Mudanças organizacionais. Conflitos organizacionais.

\footnotetext{
1 Orientador: Doutor em Educação - Universidade Federal de Pernambuco; Administrador - Universidade de Pernambuco - FCAP/UPE; Mestre em Planificación y Gestion Organizacional - UniversidadAutonoma de Madrid / Espanha; Mestre em Dirección y Organización de Hospitales y Servicios de Salud - Universidad Politécnica de Valencia / Espanha; Especialista em Marketing - FCAP/UPE; Consultor em Sistemas Organizacionais, desde 1984; Professor e Diretor Acadêmico da Faculdade Metropolitana da Grande Recife. Email: arandi.campelo@globo.com
}

2 Concluinte do curso de Gestão em Recursos Humanos da Faculdade Metropolitana da Grande Recife.

E-mail: josefelipead@outlook.com.br

${ }^{3}$ Concluinte do curso de Gestão em Recursos Humanos da Faculdade Metropolitana da Grande Recife.

E-mail: josianecalado1987@gmail.com

${ }^{4}$ Concluinte do curso de Gestão em Recursos Humanos da Faculdade Metropolitana da Grande Recife.

E-mail: isis.luiza@hotmail.com

${ }^{5}$ Concluinte do curso de Gestão em Recursos Humanos da Faculdade Metropolitana da Grande Recife.

E-mail: wr.alcantara.ss@gmail.com 


\begin{abstract}
This article sought to investigate human behavior in a company with a variable interval of 4 shifts. Some workers were exposed to conditions that bring discouragement to the team, causing people to stop producing, often due to lack of communication, as there are managers who do not know how to impose themselves with such a position. The bibliographical research had Chiavenato $(2005 ; 2019)$ as its main guide. The purpose of this article is to clarify for people to be always motivated in their work, contributing so that all participants can work and be happy, identifying the advantages that motivation offers to Call Center companies, analyzing the numerous ways of use for the improvement of the working environment. The field research, carried out at the Neobpo company, in 2021, was qualitative and purposeful, having the questionnaire as the main instrument for data collection. Field data showed that even many times people are afraid to show what they think.
\end{abstract}

Keywords: Human behavior in organizations. Organizational changes. Organizational conflicts.

\title{
INTRODUÇÃO
}

O presente cenário apresenta inúmeras mudanças que têm impactos diretos e imediatos na forma de agir de cada indivíduo. Logo, o setor de Call Center representa bem o extremo não valorizado, uma vez que ele utiliza muito mais atividades em menor período de tempo, apesar da moderna tecnologia utilizada no trabalho dos operadores. Embora muitas vezes não percebida pelas organizações, essa inconsistência entre as ênfases atribuídas à tecnologia e às pessoas pode minar as pretensões de se construir um relacionamento com o cliente, um fato que pode atrapalhar a produtividade e a qualidade do serviço.

Além disso, esse tipo de empresa conta com um trabalho considerado invisível, assim seus funcionários trabalham em constantes pressões pessoais, gerenciais, organizacionais e também provindas dos clientes. Portanto, o cotidiano de um Call Center constitui-se em um exemplo de trabalho contemporâneo, com diversos impactos.

Os funcionários de Calll Center recebem por mês em torno de um salário mínimo, mais as metas da empresa alcançadas por funcionários. Basicamente há dois tipos de colaboradores no Call Center: o receptivo e o prospectivo.

$\mathrm{O}$ receptivo fica na central de atendimento, recebe as chamadas dos clientes e as distribui para os atendentes. O prospectivo se refere aquele em que a empresa toma a iniciativa de contatar os clientes e consumidores atendidos. Assim, resulta em crescente adoecimento físico e mental.

A qualidade do serviço e a satisfação do cliente são conceitos interligados e observados pelos consumidores. Na perspectiva do consumidor a satisfação está ligada a uma busca 
individual ou um objetivo que será alcançado por meio do consumo de produtos ou serviços. No Entanto, as expectativas podem elevar ou diminuir a satisfação do cliente.

Não se deve esquecer que se o clima organizacional não for agradável, provavelmente os operadores não terão a devida motivação para realizarem um bom atendimento. O clima é favorável quando proporciona satisfação das necessidades pessoais e elevação da moral, e o mesmo é desfavorável quando proporciona frustração dessas necessidades.

\section{REFERENCIAL TEÓRICO}

É de extrema importância que a empresa Neobpo, especialista na terceirização de processos de negócios e serviços, dentro do Call Center, possua um gerenciamento que seja muito eficiente, pois normalmente os salários são baixos, precisando mais ainda incentivar a equipe para que ela esteja sempre motivada. O treinamento deve ser contínuo para que os operadores consigam atender os clientes de forma adequada, sanando todas as suas dúvidas. “À área de Recursos Humanos compete simplesmente descrever e analisar os cargos já estruturados para poder recrutar, selecionar, treinar, avaliar e remunerar seus ocupantes." (CHIAVENATO, 2005, p. 121).

Sabemos que a administração de pessoas é uma responsabilidade de linha e uma função de staff, ou seja, são dirigidas por estimular a importância de treinamento e desenvolvimento, reconhecendo que a empresa está preocupada com seu bem-estar, o que aumenta sua produtividade, tendo uma redução de custos com relação às doenças de trabalho, estreitando o relacionamento interpessoal dentro da empresa e facilitando processos. É uma peça chave para a empresa mostrar o conhecimento para os colaboradores. Dentro da empresa de Call Center geralmente quem assume a responsabilidade de linha é um supervisor junto com um coordenador de operações. Sua aplicação necessita de um acompanhamento adequado, seguindo os métodos utilizados pela gestão de pessoas, que serão executados por profissionais do departamento pessoal. (CHIAVENATO, 2005, p. 90).

Para Chiavenato (2005), o gerenciamento de pessoas requer sete aspectos fundamentais:

a) Escolha da equipe de trabalho: recrutamento e seleção dos participantes da equipe;

b) Desenho do trabalho da equipe: estruturação das tarefas e atribuições de cada membro;

c) Treinamento: contínuo treinamento e desenvolvimento dos participantes, enriquecendo o conhecimento, as habilidades e as competências;

d) Liderança: condução, orientação e impulsionamento dos membros da equipe;

e) Motivação: incentivo contínuo dos membros da equipe e administração de conflitos; 
f) Avaliação de desempenho da equipe: retroação e autodesenvolvimento pessoal de cada membro;

g) Remuneração da equipe: estabelecimento de um sistema de recompensas com base no desempenho e nos resultados alcançados;

\section{O Comportamento Humano nas Organizações}

Compreender o comportamento humano talvez seja o maior desafio que se tem para se conhecer bem as características das pessoas, pois dessa forma fica mais fácil compreender cada um dentro de sua organização. O grande problema talvez esteja em entender por que as pessoas são diferentes, agem de maneiras e formas tão distintas uma das outras. A primeira causa é a própria programação genética. Da forma que nascemos com uma programação genética para que tenhamos um funcionamento orgânico, também nascemos com uma programação genética para nossa estrutura emocional, refletindo nos padrões comportamentais, de habilidades e de aptidões. (CAMPELO, 2014).

A segunda causa, também cientificamente comprovada é a variável social, ou seja, o meio onde vivemos. (CAMPELO, 2014). É a variável social que nos diz de onde viemos, o que gostamos ou não, nossas referências, escolhas musicais ou políticas, entre outros. O homem tem sua capacidade limitada de acordo com o que pretende, não tendo capacidade para se comportar de todas as formas, pois suas características são limitadas e restritas.

Isso torna o comportamento humano variável, pois tanto sua capacidade física ou mental tem limitações. Temos diferentes necessidades e um fator tende a motivar o comportamento de uma pessoa hoje, porém no dia seguinte esse fator pode não ter força o suficiente para determinar seu comportamento, assim sendo influenciadas por várias necessidades apresentadas.

O comportamento é premeditado, proativo e cognitivamente ativo, tanto que pode ser analisado em termos e planos comportamentais que progride em estímulos para alcançar seus objetivos. De grande importância é a participação de pessoas nas organizações, pois as conduz ao envolvimento com os grupos, nos quais elas procuram manter sua identidade, segurança psicológica e utilizam o seu convívio com os outros membros para obter informações sobre si.

Os colaboradores também são vistos como recursos dentro das organizações, que carregam habilidades, poder de produção, responsabilidades, competências entre outras atribuições. O comportamento é orientado para a satisfação das suas necessidades pessoais e 
para alcançar objetivos. As pessoas podem resistir ou colaborar com as políticas e métodos das organizações dependendo das estratégias de liderança adotadas. (CHIAVENATO, 2009).

O comportamento humano está vinculado a vários fatores, desde a natureza humana até o sistema sensorial, personalidade, autoestima, caráter, sentimentos, até gerar a aprendizagem. Esses componentes moldam nosso comportamento, permitindo nos adaptar aos meios que atuamos. (SILVA, 2003).

Isso nos faz pensar nos comportamentos orientados para a satisfação das necessidades pessoais e objetivos, por isso reagimos e respondemos ao seu ambiente, tanto na organização como fora dela.

Os valores individuais variam entre si, mas costumam refletir os valores da sociedade na qual o indivíduo foi criado, sendo uma valiosa ajuda para a explicação e a previsão de comportamento. Robbins (2005) fala que as atitudes não são o mesmo que valores, mas ambos estão inter-relacionados. Dentro das organizações as atitudes são importantes, pois afetam o comportamento no trabalho. Por esse motivo as empresas estão investindo em treinamentos para remodelar as atitudes de seus funcionários.

\section{Conflitos nas Relações Organizacionais}

Compreendemos que em uma organização sempre haverá conflitos, ainda mais no setor de Call Center, pois há um número maior de pessoas e sempre haverá pensamentos e opiniões diferentes, e com isso os desentendimentos. Saber lidar com isso é o segredo.

No entanto, muitos conflitos são desnecessários e destroem valores, causando prejuízo para as empresas e pessoas que nela trabalham. O principal desafio dos gestores é identificar os produtivos e os contra produtivos, visando sempre gerenciá-los.

Há vários tipos de conflitos, sendo entre eles:

a) Conflito latente: este não é declarado e não há uma clara consciência de sua existência por parte dos envolvidos.

b) Conflito percebido: acontece quando as partes percebem e compreendem que o conflito existe ao sentirem que seus objetivos são diferentes dos objetivos dos outros e que existem oportunidades de interferência ou bloqueio.

c) Conflito sentido: atinge ambas as partes, emoções de diversos âmbitos e acontece de forma consciente onde existe o sentimento de raiva ou medo entre uma pessoa e outra e o mesmo não é manifestado. 
d) Conflito manifesto: pode ser chamado também de conflito aberto e trata-se daquele que já atingiu ambas as partes, já sendo percebido por terceiros e pode interferir na dinâmica da organização. (MARQUES, 2019).

Os conflitos no Call Center podem acontecer entre duas pessoas ou até mesmo entre grupos e abalam de maneira direta ou indireta o trabalho de determinado time ou colaborador. Diversos foram os conceitos definidos para conflito: Wisinski (1995), afirma que: "O conflito nos tempos atuais é inevitável e sempre evidente. Entretanto, compreendê-lo, e saber lidar com ele, é fundamental para o seu sucesso pessoal e profissional”. Existem ambientes e situações que potencializam a sua ocorrência, uma vez que não há esforço para que haja um bom entendimento e uma forma de trabalhar o assunto em debate sem que isso cause atritos maiores. Sempre existem motivos que causam os conflitos, sejam eles as mudanças no setor de trabalho, os recursos limitados, competição entre colaboradores, luta pelo poder, entre muitos outros fatores. Para comandar bem uma situação de conflito é essencial que as duas partes saibam se comunicar. A falta de diálogo traz impossibilidade, mas se a razão do conflito for boa e construtiva, um simples choque de opiniões pode trazer uma mudança importante e necessária.

Assim, é possível compreender que os conflitos são mais comuns do que pensamos. Só podemos saber identificar e resolver, ou tentar amenizar o máximo possível, para não ser prejudicial para o Call Center e a organização.

\section{Mudança organizacional e seus reflexos no comportamento humano}

Entende-se que as mudanças no Call Center se tornam cada vez mais inevitável, pois vem acontecendo com uma rapidez extraordinária, assim ficando difícil identificar como cada pessoa vai reagir a esses fatores, pois cada um tem sua personalidade própria.

Toda organização está sujeita a mudanças e em toda empresa existem aqueles que têm as melhores ideias, mas nem todos apreciam as mudanças. Os que fazem determinada empresa crescer são aqueles que atingem as metas o mais rápido possível, os que não veem problema em aceitar ideias, estão sempre dispostos a inovar, e estão sempre de acordo com as normas. (SPECTOR, 2008, p. 344-345).

Por gostarem de tomar decisões e fazer tudo que está ao seu alcance, muitos causam inveja, pois recebem grandes elogios e um crescimento profissional. O momento pode atestar complicado, mas muitas pessoas não se deixam abater, pois sempre reconhecem o melhor antes de qualquer pessoa. São considerados líderes proativos. 
Há também aqueles que apoiam os proativos, estão do lado para qualquer imprevisto. Não querem saber se a ideia é boa ou ruim, apenas apoiam o que os proativos falam e fazem. São muito fiéis, se arriscam apoiando, mas não fazem ideia disso. Gostam mesmo é de colaborar com tudo, sem má vontade. Assim como os proativos, quando as ideias são boas e lucrativas eles são reconhecidos pelo apoio dado à empresa.

Diferentes dos apoiadores incondicionais estão os apoiadores condicionais. Eles só apoiam quando têm certeza que não tem mais jeito e que a mudança fará bem à organização, pois se arriscam menos, mas quando apoiam é para valer. São mais inseguros, só acreditam quando veem acontecendo.

Conforme Sobral e Peci (2008, p. 207-208), há também aqueles que não sabem o que realmente querem, mudam de ideias rápido demais, tanto faz se eles estão determinados a colaborar. São submissos e vão muito pelas ideias dos outros. Têm medo de falar e de se impor para não serem mal vistos. Perdem o foco muito rápido, pois são vulneráveis e por incrível que pareça representam o maior número de pessoas de uma organização: são os indecisos.

E por último estão aqueles que não são a favor da mudança, aqueles que só veem o negativo, aqueles que não pensam na melhora da organização. Esses podem se manifestar contra qualquer decisão dada, são aqueles que só reclamam, os que mais faltam, menos trabalham, não dão nenhuma ideia motivadora para a organização e sempre falam mal de alguma coisa ou de alguém: esses são os reativos. Portanto, cada pessoa reage diferente com as mudanças, seja positivamente como negativamente, e estamos sujeitos a tudo isso desde sempre. (SILVA, 2019).

Para tentar fazer com que seus colaboradores se mantenham motivados a Neobpo estimula, oferecendo plano de carreira, realizando processo seletivo interno, dando oportunidades aos operadores de crescerem dentro da empresa.

\section{METODOLOGIA}

Os dados foram coletados através de entrevistas semiestruturadas, observações do ambiente organizacional, consulta ao site da empresa e a documentos institucionais. Foram realizadas entrevistas semiestruturadas que envolveram coordenadores, supervisores e operadores. Após coletados, os dados foram analisados qualitativamente, tendo por embasamento os aportes teóricos: 
a) Reconhecer as diferenças individuais, não tratando os colaboradores como se fossem todos iguais, pois eles possuem necessidades diferentes;

b) Definir objetivos e fornecer feedback. Deve-se trabalhar com objetivos que sejam específicos, desafiantes e que possam ser monitoráveis. Permitir que os colaboradores saibam como estão se saindo;

c) Estimular a participação nas decisões, permitindo ou encorajando a participação dos colaboradores nas decisões que os afetam, como a fixação de objetivos ou a definição dos procedimentos de trabalho.

No que tange à natureza da pesquisa, seguiu-se os seguintes parâmetros:

a) Quanto à forma: pesquisa e de campo;

b) Quanto à finalidade: aplicada;

c) Quanto ao método de análise: propositiva;

d) Quanto à abordagem: qualitativa.

A pesquisa de campo foi realizada com aplicação de um questionário, constante no apêndice A, na empresa Neobpo ${ }^{6}$.

\footnotetext{
${ }^{6}$ A Neobpo é uma empresa terceirizada no ramo de Call Center, com tecnologia moderna, buscando sempre inovar e capacitar os operadores através de treinamentos e cursos (NeoFuture). A Neo foi criada a partir da divisão dos negócios da Tivit, uma das maiores empresas brasileiras de serviço de tecnologia, para atender de forma especializada serviços de atendimento automatizado de clientes, conhecida como BPO. Com o portifólio completo e abrangendo os principais setores do mercado, oferecendo uma cultura de inovação, guiando os clientes para escolher a melhor estratégia de implementar as soluções de forma personalizada.
} 


\section{DESENVOLVIMENTO DA PESQUISA DE CAMPO}

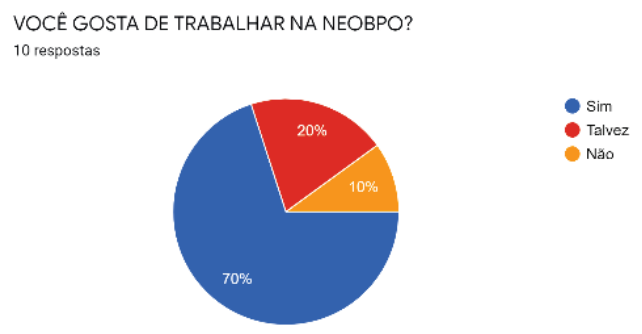

Nesta questão, $70 \%$ dos entrevistados afirmaram gostar de trabalhar na Neobpo. A empresa tem programas internos de reconhecimento, plano de carreira, e oferece aos funcionários benefícios como vale refeição, vale transporte e plano de saúde.

A SUA REMUNERAÇÃO É COMPATIVEL COM AS ATIVIDADES EXERCIDAS? 10 respostas

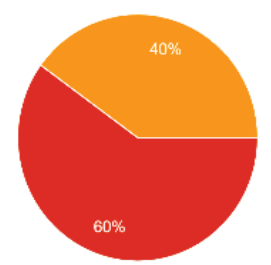

- SIM

Nāo

$60 \%$ dos entrevistados responderam que a sua remuneração está na média, levando em consideração as atividades realizadas na empresa, pois tem dias que as demandas de atividades são inesgotáveis.

VOCÊ SE SENTE DESMOTIVADO NA ATUAL EMPRESA? 10 respostas

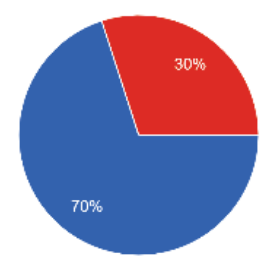

- Sim

Às vezes, cobranças excessivas e interesses pessoais não atendidos fazem com que $70 \%$ dos entrevistados fiquem desmotivados. Conforme Sobral e Peci (2008, p. 207-208), há também aqueles que não sabem o que realmente querem, mudam de ideia rápido demais, tanto faz se eles estão determinados a colaborar. 
A SUA EMPRESA INVESTE EM DIVERSIDADES?

10 respostas

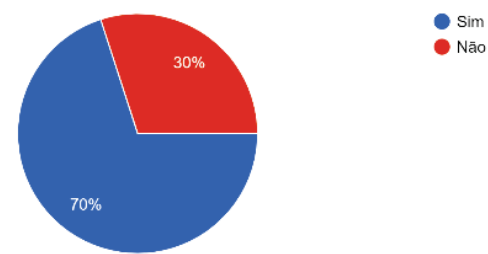

Nesta questão, 70\% dos entrevistados afirmaram que a empresa Neobpo investe em programas, palestras, comemorações de datas especiais relacionada à diversidade.

VOCÊ ACHA SEU GESTOR PREPARADO PARA SUPERVISIONAR A EQUIPE? 10 respostas
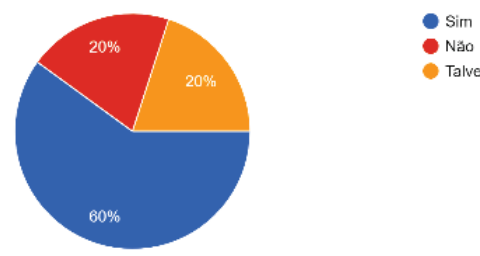

Talvez

Aqui, $60 \%$ dos entrevistados afirmaram que seu gestor está apto para assumir os desafios e gerenciamento da equipe. A capacidade de ser exigente quando precisa obter um resultado; a seriedade com que encara as situações e desenvolve as atividades; a noção de justiça e o exemplo da disciplina; e a capacidade de ordenar o que precisa ser seguido, ser realizado. (Campelo 2014, pag. $80)$.

VOCÊ DIÁLOGA COM SEU SUPERIOR?

10 respostas

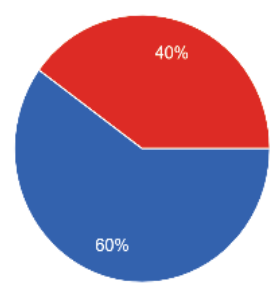

SIM

Nesta questão $60 \%$ dos entrevistados afirmaram ter um bom diálogo com o seu superior, por ele ser um profissional sociável. O comportamento é orientado para a satisfação das suas necessidades pessoais e para alcançar objetivos. As pessoas podem resistir ou colaborar com as políticas e métodos das organizações dependendo das estratégias de liderança adotadas. (CHIAVENATO, 2009). 
SEU GESTOR LHE DÁ AUTONOMIA PARA TRABALHAR? 10 respostas

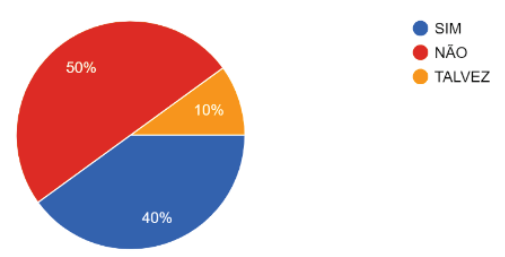

50\% dos entrevistados não recebem autonomia para tomar decisões imediatas, por conta da política e cultura da empresa que impede o colaborador de resolver certas situações em que às vezes necessita de flexibilidade.

VOCÊ SE ACHA COMPETENTE NO CARGO QUE EXERCE?

12 respostas

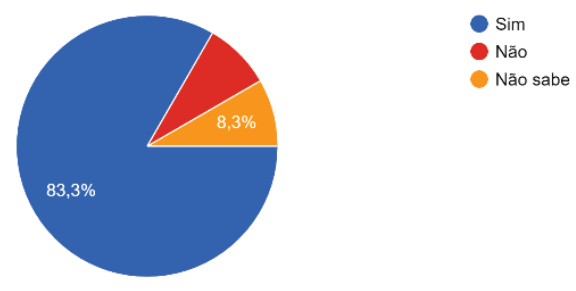

$83,3 \%$ dos entrevistados afirmam estarem exercendo suas atividades com competência. Sua aplicação necessita de um acompanhamento adequado, seguindo os métodos utilizados pela gestão de pessoas que serão executadas por profissionais do departamento pessoal. (CHIAVENATO, 2005, p. 90).

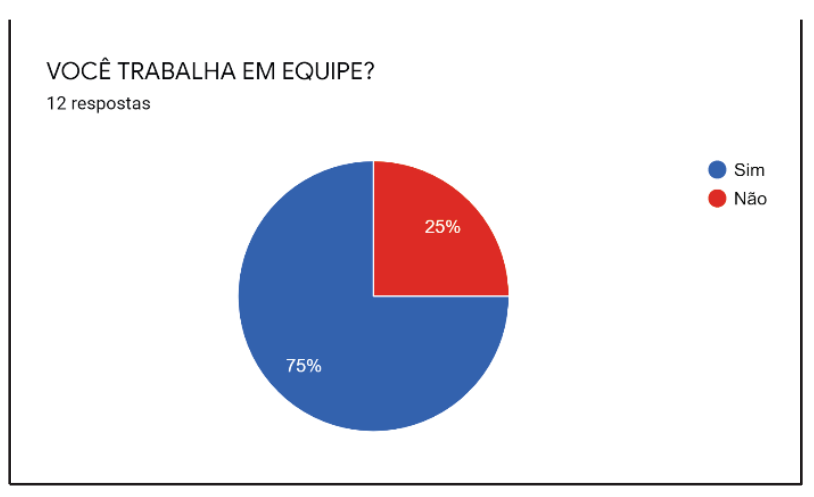

De acordo com o gráfico apresentado, $75 \%$ dos colaboradores responderam positivamente ao afirmarem que mantém um trabalho em equipe. 
VOCÊ É FELIZ EM TRABALHAR AQUI?

12 respostas

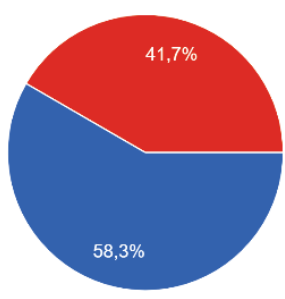

Sim

Não

$53 \%$ dos entrevistados afirmaram ser feliz em trabalhar na NEOBPO. Considera-se um número abaixo do esperado. Os que fazem determinada empresa crescer são aqueles que atingem as metas o mais rápido possível, os que não veem problema em aceitar ideias, estão sempre dispostos a inovar, e estão sempre de acordo com as normas. (SPECTOR, 2008, p. 344-345).

VOCÊ TEM DOMINIO NO SISTEMA AO QUE OPERA?

12 respostas
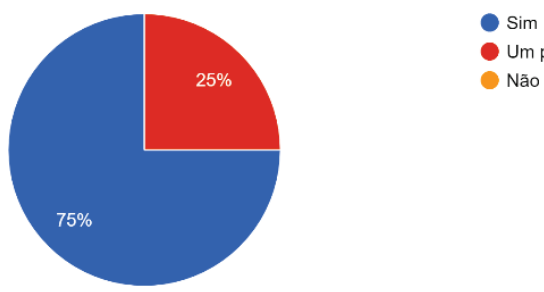

Um pouco

Não

$75 \%$ dos entrevistados têm domínio sobre o sistema no qual atuam, identificando que os sistemas têm as ferramentas necessárias para uso profissionais e afins. Robbins (2005) cita que as atitudes não são o mesmo que valores, mas ambos estão inter-relacionados. Dentro das organizações as atitudes são importantes, pois afetam o comportamento no trabalho. Por esse motivo as empresas estão investindo em treinamentos para remodelar as atitudes de seus funcionários. 
VOCÊ GOSTA DO SEU HORÁRIO DE TRABALHO?

12 respostas

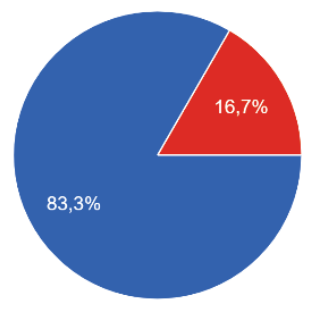

Năo

$83,3 \%$ dos entrevistados responderam estar satisfeitos com o seu horário de trabalho.

QUAL HORÁRIO VOCÊ GOSTARIA DE TRABALHAR?

12 respostas

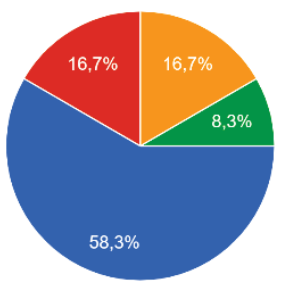

matuTino

INTERMÉDIO

TARDE

Nesta questão 58,3\% dos colaboradores responderam que gostariam de trabalhar na parte da manhã. Portanto, cada pessoa reage diferente com as mudanças, seja positivamente como negativamente, e estamos sujeitos a tudo isso desde sempre. (SILVA, 2019).

O SEU GESTORÉ ALEGRE?

12 respostas

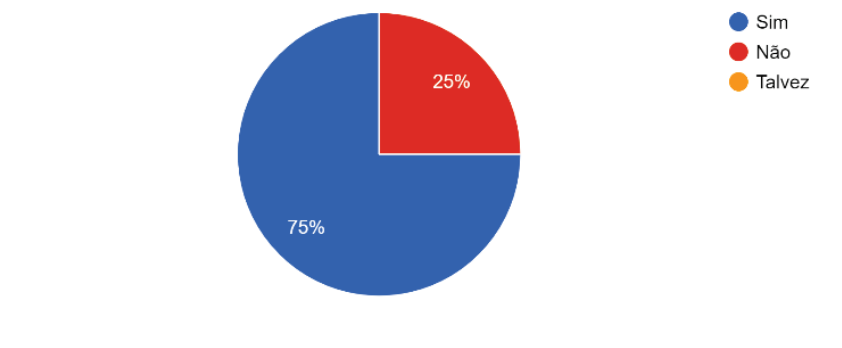

Sim

- Năo

Talvez

$75 \%$ dos entrevistados consideram o seu gestor uma pessoa alegre. Isso torna o clima organizacional mais harmonioso. 
O SEU GESTORÉ COMPREENSIVEL?

12 respostas

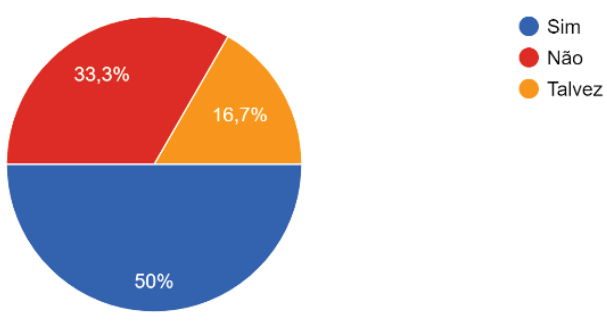

Nesta questão nota-se que $50 \%$ dos entrevistados afirmaram ter um gestor compreensível. Wisinski (1995) afirma que: “O conflito nos tempos atuais é inevitável e sempre evidente. Entretanto, compreendê-lo, e saber lidar com ele, é fundamental para o seu sucesso pessoal e profissional".

VOCÊ DIÁLOGA COM SEU SUPERIOR?

12 respostas

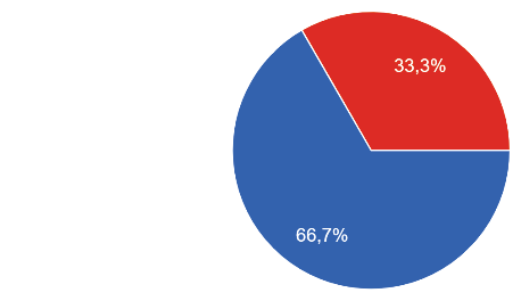

NÃO

A maioria dos entrevistados mantém um bom diálogo com o seu superior, a fim de manter uma boa relação entre líder e liderado.

\section{CONSIDERAÇÕES FINAIS}

Esse trabalho possibilitou conhecer de forma mais ampla a história da Neobpo e seus avanços em plena pandemia, assim como a vida dos operadores. Houve uma mudança muito produtiva para todos que trabalham na empresa para poder continuar suas atividades sem prejudicar os clientes. A empresa adotou o sistema home office para continuar o atendimento. Dessa forma, trouxe uma comodidade tanto para os trabalhadores e também para os clientes que não deixaram de receber seus atendimentos através do serviço prestado pela empresa. Mesmo com essas mudanças a empresa continuou dando lucro e continuou contratando pessoas para ocupar cargos importantes na empresa, porém, mesmo com tantas mudanças, a 
empresa usa a fragilidade do país, sobretudo no momento que estamos enfrentando, para causar medo nos operadores.

Ao verificar o medo de cada pessoa que faz parte dessa organização foi identificado que nem tudo que se fala é praticado no ambiente de trabalho, pois a situação piora a cada momento, e durante a pandemia houve muitas mudanças e a empresa está aproveitando do relaxamento da CLT e as brechas obtidas nas leis para assim informar que está com problemas financeiros. Todos percebem que não existe nenhuma dificuldade, pois a empresa demite um colaborador hoje e contrata outro no dia seguinte.

Diante do exposto é recomendável que todos busquem sempre se qualificar para garantir novas oportunidades.

\section{REFERÊNCIAS}

CAMPELO, Arandi Maciel. Gestão de pessoas: Compreendendo o comportamento humano nas organizações 6.ed. Recife: FcapBooks, 2014.

CHIAVENATO, Idalberto. Recursos humanos, o capital humano nas organizações. Disponível em: https://gennegociosegestao.com.br/resenha-recursos-humanos/

Acesso em: 12 abr. 2021.

CHIAVENATO, Idalberto. Comportamento Organizacional: a dinâmica do sucesso das organizações, Rio de Janeiro: Elsevier, 2005.

MARQUES, José Roberto. Conheça os tipos de conflitos nas organizações. São Paulo: 22 de novembro 2019. Disponível em: https://www.ibccoaching.com.br/portal/conheca-os-tiposde-conflitos-nas-organizacoes/ Acesso em: 12 maio 2021.

\section{NEOBPO. Quem somos.}

Disponível em: https://neobpo.com.br/quem-somos/

https://neobpo.com.br/transforme-a-experiencia-do-cliente-com-a-evolucao-tecnologica-doseu-website Acesso em: 12 maio 2021.

ROBBINS, Stephen P. Comportamento Organizacional: Tradução Reynaldo Marcondes. 11. ed. São Paulo: Pearson Prentice Hall, 2005.

SILVA, Francisco Souza. Liderança e comportamento organizacional: uma relação intrínseca na gestão. Edição v. 23 n. 37 (2019)

Disponível em: https://revista.pgsskroton.com/index.php/rcger/article/view/6493

Acesso em: 23 mar. 2021.

SILVA, Gustavo Melo. Implementação de mudança: uma aplicação de um sistema de medição de desempenho - SMD. 2003. 
Disponível em: https://www.estantevirtual.com.br/livros/filipe-sobral-e-alketapeci/administracao-teoria-e-pratica-no-contextobrasileiro/1875420975?gclid=Cj0KCQjw5PGFBhC2ARIsAIFIMNesJvDIMtwLCXPIDOI4c OS79Rt_DxBNRX31IzWXLK3EIx3T3RoLL-saAhmEEALw_wcB

Acesso em: 23 mar. 2021.

SOBRAL, Filipe; PECI, Alketa. Administração: teoria e prática no contexto brasileiro. São Paulo: Pearson Prentice Hall, 2008.

SPECTOR, Paul E. Psicologia nas organizações. Tradução Solange Aparecida Visconte. 2. ed. São Paulo: Saraiva, 2008.

WISINSKI, Jerry. Como resolver conflitos no trabalho. Tradução Renata Silva Cardoso. Rio de Janeiro: Campus, 1995.

\section{APÊNDICE A - Questionário utilizado na pesquisa de campo}

1. Você gosta de trabalhar na NEOBPO?
A. Sim
B. Talvez
C. Não

2. A sua remuneração é compatível com as atividades exercidas? *
A. $\operatorname{Sim}$
B. Na média
C. Não

3. Você se acha competente no cargo que exerce? *
A. $\operatorname{Sim}$
B. Não
C. Não sabe

4. Você se sente desmotivado na atual empresa? *
A. $\operatorname{Sim}$
B. Não

5. Você trabalha em equipe?*
A. $\operatorname{Sim}$
B. Não

6. Você é feliz em trabalhar aqui? *
A. $\operatorname{Sim}$
B. Não

7. Você tem domínio no sistema ao que opera? *
A. Sim
B. Um pouco
C. Não

8. Você gosta do seu horário de trabalho? *
A. $\operatorname{Sim}$
B. Não

9. Qual horário você gostaria de trabalhar? *
A. Matutino
B. Intermédio 
C. Tarde

D. Noite

\section{APÊNDICE B - Questionário para avaliação do gestor}

1. O seu gestor é alegre? *
A. $\operatorname{Sim}$
B. Não
C. Talvez
2. O seu gestor é compreensível? *
A. $\operatorname{Sim}$
B. Não
C. Talvez
3. Você dialoga com seu superior? *

A. Sim
B. Não 


\title{
CONTABILIDADE EM ORGANIZAÇÕES DO TERCEIRO SETOR: A PRESTAÇÃO DE CONTAS DE UMA OSCIP EM RECIFE
}

https://dx.doi.org/10.48097/2674-8673.2022n6p05

Elizany Ivania de Santana ${ }^{1}$

Waldete Moura de Lima $^{2}$

Tarciana Borges Ferreira ${ }^{3}$

\section{RESUMO}

O presente trabalho apresenta o resultado de uma pesquisa realizada na empresa SoftexCentro de Excelência em Tecnologia de Software de Recife. O intuito é mostrar as práticas contábeis de uma empresa sem fins lucrativos de acordo com as Normas Brasileiras de Contabilidade. O nosso universo foi sobre as demonstrações contábeis prestadas por uma OSCIP conforme as Normas Brasileiras de Contabilidade. O tipo de pesquisa desenvolvida quanto à forma foi bibliográfica e de campo; quanto a finalidade: aplicada; quanto ao método de análise: propositiva; quanto a abordagem: qualitativa. $\mathrm{O}$ instrumento de pesquisa foi um questionário fechado, com perguntas e alternativas de múltipla escolha. O objeto de estudo desse artigo foi a Contabilidade de uma Organização de Sociedade - OSCIP.

Palavras-chave: Terceiro Setor. OSCIP. Prestação de Contas.

Data de submissão: 09/09/2021

Data de aprovação: $26 / 10 / 2021$

\begin{abstract}
The present work presents the result of a research carried out at the company Softex- Recife Center for Excellence in Software Technology. The purpose is to show the accounting practices of a non-profit company in accordance with the Brazilian Accounting Standards. Our universe was about the financial statements provided by an OSCIP in accordance with the Brazilian Accounting Standards. The type of research developed in terms of form was: bibliographic and field; as for the purpose: applied; regarding the method of analysis: propositional; as for the approach: qualitative. The research instrument was a closed questionnaire, with multiple choice questions and alternatives. The object of study of this article was the Accounting of an Organization of Society - OSCIP.
\end{abstract}

Keywords: Third Sector. OSCIP. Accountability.

\footnotetext{
${ }^{1}$ Concluinte do curso de Bacharelado em Ciências Contábeis da Faculdade Metropolitana da Grande Recife.

E-mail: elizanysantana@hotmail.com

${ }^{2}$ Concluinte do curso de Bacharelado em Ciências Contábeis da Faculdade Metropolitana da Grande Recife.

E-mail: waldetemoura@hotmail.com

${ }^{3}$ Docente orientadora do curso de Ciências Contábeis da Faculdade Metropolitana da Grande Recife.

E-mail: tarciana@metropolitana.edu.br
} 


\section{INTRODUÇÃO}

Terceiro setor é uma expressão criada para designar um campo da sociedade correspondente às ações sociais promovidas por instituições privadas de caráter não lucrativo, com atividades que envolvem a demanda pela reivindicação de determinadas causas ou ações de filantropia. Esse termo foi criado para diferenciar essas instituições da esfera governamental (o Primeiro Setor) e da esfera privada com fins lucrativos (o Segundo Setor ou mercado). As mais conhecidas instituições do Terceiro Setor são as ONGs (Organizações Não Governamentais), havendo também as fundações, entidades beneficentes, os fundos comunitários, as entidades sem fins lucrativos, associações de moradores, entre outras. Em vista legal (Código Civil), as ONGs são pessoas jurídicas, de direito privado, constituídas em forma de associações ou fundações e para garantir os direitos sociais básicos e combater a exclusão social. Estas entidades são mantidas por iniciativas privadas, doações e até mesmo repasses de verbas públicas.

Como qualquer projeto ou empresa, uma entidade do Terceiro Setor precisa ser economicamente sustentável para que tenha continuidade. É possível ainda produzir e comercializar produtos e serviços, porém a receita e o superávit alcançados deverão ser totalmente revertidos para a manutenção e melhoria da entidade. E mesmo não visando o lucro, é extremamente importante ter um acompanhamento contábil eficiente para ter melhores resultados em suas ações, principalmente na demonstração da aplicação dos recursos obtidos.

\section{REFERENCIAL TEÓRICO}

O referencial desse estudo tem o objetivo de apresentar a grande importância da contabilidade para o terceiro setor, pois, com o auxílio desta, é possível demonstrar para a sociedade o trabalho que realmente vem sendo desenvolvido por parte dessas instituições sem fins lucrativos.

\section{Conceito de Terceiro Setor}

De Acordo com o SINIBREF (2016) o terceiro setor é um grupo formado pelas associações e fundações de direito privado, sem fins lucrativos, que buscam, dentre suas finalidades, o alcance do bem estar social. Essas instituições apresentam, ao mesmo tempo, características intrínsecas ao setor estatal, quando administram recursos públicos e buscam fins sociais, e ao setor privado, devido a sua própria constituição e natureza jurídica. 
Antes de conceituar o terceiro setor é interessante conhecer os outros dois setores existentes. O Estado é considerado o primeiro setor, compreendendo todas as esferas governamentais e abrangendo as instituições federais, estaduais e municipais "[...]: isto é, as prefeituras municipais, os governos dos estados e o presidente da república [...]”. Já o segundo setor, também chamado de "mercado", é constituído por empresas privadas, que competem entre si e trabalham visando o próprio lucro, que é obtido por meio de atividades econômicas, podendo ser a comercialização tanto de produtos, quanto de serviços. (E-DOU, 2017).

Diante desse entendimento, se compreende que existe uma conexão entre o terceiro setor e os demais setores. Paes (1999) destaca que:

O terceiro setor é composto por organizações de natureza "privada" (sem o objetivo de lucro), dedicadas à consecução de objetos sociais ou públicos, embora não seja integrante do governo (Administração Estatal). Podemos assim conceituar o Terceiro Setor como o conjunto de organismos, organizações ou instituições dotadas de autonomia e administração própria que apresentam como função e objetivo principal atuar voluntariamente junto à sociedade civil visando ao seu aperfeiçoamento. (PAES, 1999, p. 46).

O Observatório do Terceiro Setor (2019) conceitua que, “[...] o terceiro setor é composto por organizações sem fins lucrativos e de interesse público, as chamadas organizações da sociedade civil (OSCs)". Paes (1999) ressalta que:

O terceiro setor tem um caráter estratégico da maior importância no âmbito de qualquer sociedade que se preocupe com o desenvolvimento social e a consolidação de valores democráticos, pluralistas, comprometidos com a solidariedade humana e o sentido de comunidade. (PAES, 1999, p. 47).

\section{Características do Terceiro Setor}

De acordo com o art. 44 do Novo Código Civil (Lei 10.406 de 2002), são pessoas jurídicas de direito privado: as associações; as sociedades; as fundações; as organizações religiosas; os partidos políticos. Conforme especifica Grazzioli et al (2015):

A associação é uma modalidade de agrupamento dotada de personalidade jurídica, sendo pessoa jurídica de direito privado voltado à realização de interesses dos seus associados ou de finalidade de interesse social, cuja existência legal surge com a inscrição do seu estatuto, em forma pública ou particular, no registro competente, desde que satisfeitos os requisitos legais (CC Art. 45), que ela tenha objetivo licito e esteja regularmente organizada. (GRAZZIOLI et al, 2015, p. 22).

Na visão de Menezes (2003), a associação é citada como uma pessoa jurídica de direito privado, criada com base na união de pessoas, em torno de uma finalidade não lucrativa. Segundo Grazzioli (2015):

[...] assim como as associações, as organizações religiosas são pessoas jurídicas formadas por pessoas que se unem para a realização de atividades sem finalidade lucrativa, voltadas à religiosidade e à profissão de fé, muitas vezes realizando atividade para a coletividade. (GRAZZIOLI et al, 2015, p. 43). 
O novo Código Civil, no art. 981, declara que se constitui sociedade as pessoas que mutuamente compelem a colaborar com bens ou serviços, para o exercício de atividade econômica e a partilha, entre si, dos resultados.

A maioria das organizações do terceiro setor goza de imunidade ou isenção tributária, sendo necessário, para tanto, o atendimento a pré-requisitos previstos na Constituição Federal, no Código Tributário Nacional, e em leis específicas. Uma dessas exigências para a obtenção do benefício fiscal corresponde à manutenção da escrituração das receitas e despesas em livros revestidos de formalidades capazes de assegurar sua exatidão, o que significa aderência às normas contábeis, em especial à Interpretação Técnica Geral nº 2002 - Entidade sem Fins de Lucro, aprovada pela Resolução do Conselho Federal de Contabilidade nº 1.409/2012.

\section{Normas Brasileiras de Contabilidade Referentes ao Terceiro Setor}

A Norma Brasileira de Contabilidade - NBC T 10.19.1.3 tem por objetivo definir os procedimentos que avaliam e registram os elementos e as variações patrimoniais da estrutura das demonstrações contábeis e as informações detalhadas a serem divulgadas em notas explicativas da instituição sem fins lucrativos. (CONSELHO FEDERAL DE CONTABILIDADE, 2002). Segue abai xo as normas que regem essa categoria:

NBCT TG - Estrutura Conceitual para Elaboração e Apresentação das Demonstrações Contábeis (Resolução Conselho Federal de Contabilidade 1.374/11);

NBC TG 07 (R2) - Subvenção e Assistência Governamentais (Resolução CFC /17);

NBC TG 26 (R5) - Apresentação das Demonstrações Contábeis (Resolução CFC /17);

Princípios da Contabilidade (Resolução CFC 1.282/10);

ITG (Interpretação Técnica Geral) 2000 (R1) - Escrituração Contábil (Resolução $\mathrm{CFC} / 11)$;

ITG (Interpretação Técnica Geral) 2002 (R1) - Entidade sem finalidades de lucros (Resolução CFC 1.412/15).

\section{Qualificação da OSCIP}

De acordo com o artigo $3^{\circ}$ da Lei $n^{\circ} .9 .790 / 99$ que determina a qualificação instituída somente será dada às pessoas jurídicas de direito privado, sem fins lucrativos, cujos objetivos sociais tenham pelo menos uma das seguintes finalidades: 
I - promoção da assistência social; II- promoção da cultura, defesa e conservação do patrimônio histórico e artístico; III- promoção gratuita da educação, observando-se a forma complementar de participação das organizações de que trata esta Lei; IVpromoção gratuita da saúde, observando-se a forma complementar de participação das organizações de que trata esta Lei; V- promoção da segurança alimentar e nutricional; VI- defesa, preservação e conservação do meio ambiente e promoção do desenvolvimento sustentável; VII- promoção do voluntariado; VIII- promoção do desenvolvimento econômico e social e combate à pobreza; IX-experimentação, não lucrativa, de novos modelos socioprodutivos e de sistemas alternativos de produção, comércio, emprego e crédito; X- promoção de direitos estabelecidos, construção de novos direitos e assessoria jurídica gratuita de interesse suplementar; XI- promoção da ética, da paz, da cidadania, dos direitos humanos, da democracia e de outros valores universais; XII- estudos e pesquisas, desenvolvimento de tecnologias alternativas, produção e divulgação de informações e conhecimentos técnicos e científicos que digam respeito às atividades mencionadas neste artigo. XIII- estudos e pesquisas para o desenvolvimento, a disponibilização e a implementação de tecnologias voltadas à mobilidade de pessoas, por qualquer meio de transporte. (BRASIL, 1999).

Mediante o cumprimento do art. $5^{\circ}$ da Lei $n^{\circ} .9 .790 / 99$, a pessoa jurídica de direito privado sem fins lucrativos interessados em obter a qualificação de OSCIP, deverá requerer requerimento escrito ao Ministério Público, instruídos com os seguintes documentos: "Iestatuto registrado em cartório; II- ata de eleição de sua atual diretoria; III- balanço patrimonial de demonstração do resultado do exercício; IV- declaração de isenção de imposto de renda; V- inscrição no cadastro geral de contribuintes". (BRASIL, 1999). Segundo o Grazzioli, os principais benefícios da qualificação de OSCIP são:

A possibilidade de celebração do termo de parceria com o Poder Público para o recebimento de recursos; A possibilidade de o doador - pessoa jurídica - deduzir do cálculo do lucro real e da base de cálculo da Contribuição Social sobre o Lucro até o limite de $2 \%$ sobre o lucro operacional, o valor das doações efetuadas, conforme previsto no Art. 59, da Medida Provisória n ${ }^{\circ}$ 2.158-35, de 27/8/20014 e Art. 34 da Lei ${ }^{\circ} 10.637 / 2002$. (GRAZZIOLI et al, 2015, p. 77).

\section{Evidenciação de Receita e Despesa}

Segundo o Conselho Federal de Contabilidade, a Interpretação Técnica Geral (ITG2002) enfatiza que:

As receitas e as despesas devem ser reconhecidas, respeitando-se o regime contábil de competência. As doações e subvenções recebidas para custeio e investimentos devem ser reconhecidas no resultado observado o disposto na NBC TG 07 Subvenção e Assistência Governamentais. Os registros contábeis devem evidenciar as contas de receitas e despesas, com e sem gratuidade, superávit ou déficit, de forma segregada, identificáveis por tipo de atividade, tais como educação, saúde, assistência social e demais atividades. (CONSELHO FEDERAL DE CONTABILIDADE, 2002).

\footnotetext{
${ }^{4}$ Altera a legislação das Contribuições para a Seguridade Social - COFINS, para os Programas de integração Social e de Formação do Patrimônio do Servidor Público - PIS/PASEP e do Imposto sobre a Renda, e dá outras providências.
} 


\title{
Demonstrações Financeiras
}

As entidades sem fins lucrativos devem elaborar as demonstrações contábeis de acordo com a ITG 2002 - Entidade sem finalidade de lucro, as demonstrações exigidas são: Balanço Patrimonial, Demonstrações do Resultado do Período, Demonstrações das Mutações do Patrimônio Líquido, Demonstrações do Fluxo de Caixa e Notas Explicativas.

\begin{abstract}
No Balanço Patrimonial, a denominação da conta Capital deve ser substituída por Patrimônio Social, integrante do grupo Patrimônio líquido. No Balanço Patrimonial e nas Demonstrações do Resultado do Período, das Mutações do Patrimônio Líquido e dos Fluxos de Caixa, as palavras lucro ou prejuízo devem ser substituídas por superávit ou déficit do período. Na Demonstração do Resultado do Período, devem ser destacadas as informações de gratuidade concedidas e serviços voluntários obtidos, e divulgadas em notas explicativas por tipo de atividade. Na Demonstração dos Fluxos de Caixa, as doações devem ser classificadas nos fluxos das atividades operacionais. (CONSELHO FEDERAL DE CONTABILIDADE, 2002).
\end{abstract}

\section{Prestações de Contas das OSCIPS}

A prestação de contas implica em comprovar de forma correta a utilização dos recursos revertidos à Organização da Sociedade Civil de Interesse Público. Então, de acordo com o Decreto 3.100, de 30 de junho de 1999, a prestação de contas será formada com os seguintes relatórios:

Documento anual de execução de atividades;

Demonstração de resultados do exercício;

Balanço patrimonial;

Demonstração das origens e aplicações de recursos;

Demonstração das mutações do patrimônio social;

Notas explicativas;

Parecer e relatório de auditoria.

Se houver a efetivação do termo de parceria, é necessária a evidenciação, junto ao órgão parceiro, para mostrar o uso correto dos recursos públicos com os seguintes documentos, de acordo com o artigo 11 do Decreto 3.100/995:

I- Relatório anual de execução de atividades, contendo especificamente relatório sobre a execução do objeto do Termo de Parceria e comparativo entre as metas propostas e os resultados alcançados; II- Demonstrativo integral da receita e despesa realizadas na execução; III- Extrato da execução física e financeira; IV Demonstração de resultado do exercício; V-Balanço patrimonial; VI- Demonstração das origens e aplicações de recursos; VII- Demonstração das mutações do patrimônio social; VIII- Notas explicativas das demonstrações contábeis; IXParecer e relatório de auditoria. (BRASIL, 1999).

\footnotetext{
${ }^{5}$ Decreto $n^{\circ} 3100$, de 30 de junho de 1999 - regulamenta a lei n 9.790, de 23 de março de 1999, que dispõe sobre a qualificação de pessoas jurídicas de direito privado, sem fins lucrativos, como Organização da Sociedade Civil de Interesse Público, institui e disciplina o Termo de Parceria, e dá outras providências.
} 
A prestação de contas da entidade deve ser feita por um contador registrado no Conselho Regional de Contabilidade, observando as Normas Brasileiras de Contabilidade e os princípios fundamentais da contabilidade.

\section{METODOLOGIA}

O objeto de estudo desse artigo foi a contabilidade de uma Organização de Sociedade Civil de Interesse Público - OSCIP. Cujo objetivo geral foi identificar quais os procedimentos contábeis utilizados em uma organização do terceiro setor, formando assim os seguintes objetivos específicos: caracterizar as entidades do terceiro setor, apresentar alguns aspectos legais das entidades do terceiro setor e identificar os procedimentos contábeis utilizados na OSCIP.

O campo investigativo da pesquisa foi realizado na empresa Softex, localizada na cidade do Recife. O estudo foi sobre as demonstrações contábeis prestadas por uma OSCIP, conforme as Normas Brasileiras de Contabilidade. O tipo de pesquisa desenvolvida quanto à forma foi bibliográfica e de campo, com finalidade aplicada, método de análise propositiva, e de abordagem qualitativa. O instrumento de pesquisa foi um questionário fechado com perguntas e alternativas de múltipla escolha.

O Centro de Excelência em Tecnologia de Software do Recife - Softex Recife, qualificada como Organização da Sociedade Civil de Interesse Público - OSCIP, nos termos da Lei ${ }^{\circ}$ 9.970, de 23 de Março de 1999, caracteriza-se como uma instituição de educação, ensino e pesquisa de apoio ao desenvolvimento organizacional, institucional, técnico e econômico, tendo por finalidade conceber, desenvolver e executar atividades ligadas à pesquisa, extensão e inovação no campo da tecnologia da informação, tecnologia social e gestão, objetivando a promoção da sociedade, modernização e competitividade no Estado de Pernambuco, na Região Nordeste e no país.

\section{Desenvolvimento da Pesquisa de Campo}

O desenvolvimento da pesquisa de campo foi realizado na cidade de Recife, na empresa Softex - Centro de Excelência em Tecnologia de Software de Recife, que é uma Organização da Sociedade Civil de Interesse Público - OSCIP. O intuito da pesquisa foi mostrar as práticas contábeis de uma empresa sem fins lucrativos de acordo com as Normas Brasileiras de Contabilidade. 


\section{A Empresa}

A Softex Recife é uma associação de empresas de Tecnologia da Informação de Comunicação (TIC), sem fins lucrativos, criada em 8 de novembro de 1994. Foi o sexto núcleo criado no país. Em 2006 foi reconhecida como OSCIP - Organização da Sociedade Civil de Interesse Público nos níveis municipal, estadual e federal, com registro junto ao CATI - Conselho de Atividades de Tecnologia da Informação do Ministério da Ciência e Tecnologia. A missão da empresa é incrementar o sistema de negócios de TIC em Pernambuco, promovendo a integração, capacitação e certificação empresarial apoiando a inserção competitiva das empresas no mercado para aumentar os seus resultados.

A entidade ultrapassou a marca de 200 empresas associadas. A mesma está sediada no Bairro do Recife, onde administra um prédio próprio com 5 mil metros quadrados de área geral e 3.880 metros quadrados de área locável. Além das salas empresarias, conta com um centro de convenções no térreo, onde funciona um auditório para 50 pessoas, salas de reuniões e treinamentos, espaço para a realização de coffebreak, refeitório coletivo, um telhado verde para eventos e o Mangue Space, um coworking funcional e acessível.

\section{Instrumento para Coleta de Dados}

A entrevista foi realizada com o Coordenador Geral Eduardo Antônio Paiva de Almeida, que atua na empresa desde 2001. O mesmo informou que para um melhor acompanhamento as informações contábeis são preparadas mensalmente. Os relatórios são utilizados para prestar contas aos financiadores e para controle das operações. As demonstrações contábeis foram elaboradas de acordo com as práticas contábeis adotadas no Brasil, com base nas disposições contidas na ITG 2002 - Entidades sem finalidades de lucros, aprovada pela Resolução CFC n 1.409 de 21 de setembro de 2012, pelo comunicado Técnico CTG 2000, aprovado pela Resolução CFPC n 1.159 de 13 de fevereiro de 2009 e pela ITG 1000 - Modelo Contábil para Microempresa e Empresa de Pequeno Porte.

\section{Registros das Receitas}

As receitas e despesas são controladas através de um sistema ERP chamado PIRAMIDE. Além desse sistema se faz uso também de um acompanhamento do Fluxo de Caixa, por meio de uma planilha eletrônica. A contabilização das receitas e despesas de projetos terceiros são registradas nas contas do passivo, respeitando-se o regime de competência. 
Tabela 1 - Receita de atividades

\begin{tabular}{lcc}
\hline RECEITAS & 2019 & 2018 \\
\hline DOAÇÃO & 3.766 .799 & $\mathbf{3 . 0 9 0 . 6 8 9}$ \\
CONTRATOS/ PATROCÍNIOS & $\mathbf{1 . 6 7 7 . 3 5 4}$ & $\mathbf{1 . 9 9 3 . 7 1 8}$ \\
CONSULTORIA & $\mathbf{3 2 1 . 4 0 7}$ & $\mathbf{5 2 7 . 7 5 9}$ \\
ASSOCIADOS & $\mathbf{2 5 4 . 2 8 6}$ & $\mathbf{2 0 2 . 2 0 0}$ \\
TAXA DE ADMINISTRAÇÃO & $\mathbf{2 6 1 . 6 8 6}$ & $\mathbf{4 3 . 5 2 1}$ \\
GESTÃO DE PROJETOS & $\mathbf{3 5 6 . 2 1 3}$ & $\mathbf{2 9 8 . 5 8 9}$ \\
CURSOS & $\mathbf{1 . 8 0 0}$ & - \\
RECEITA DE LOCAÇÃO & - & - \\
ALUGUEL & $\mathbf{1 . 7 8 2 . 8 6 9}$ & $\mathbf{1 . 6 6 1 . 5 5 5}$ \\
CONDOMÍNIO & $\mathbf{6 7 2 . 3 5 9}$ & $\mathbf{7 1 6 . 8 6 5}$ \\
OUTRAS RECEITAS & $\mathbf{1 1 . 9 4 9}$ & - \\
\hline
\end{tabular}

Fonte: Softex 2019

\section{Registros das Despesas}

A tabela 1 mostra quais as origens dos valores que foram adquiridos para a manutenção da empresa e desenvolvimento dos projetos. Já na tabela 2 é esclarecido onde foram aplicadas as receitas obtidas. Essas tabelas estão relacionadas às informações que estão transcritas na demonstração do resultado. Dessa maneira a empresa revela transparência na apresentação de seus relatórios.

Tabela 2 - Custo dos Serviços Prestados e Despesas Gerais e Administrativas

\begin{tabular}{lcc}
\hline CUSTOS SERVIÇOS & 2019 & 2018 \\
\hline BOLSAS & 3.952 .701 & 3.039 .747 \\
DEPRECIAÇÃO & 320.253 & 317.725 \\
OUTROS CUSTOS & 130.219 & 101.245 \\
& & \\
DESPESAS & 2019 & 2018 \\
CARTÓRIOS & 3.886 & $\mathbf{5 . 0 7 7}$ \\
DESPESAS DIVERSAS & $\mathbf{2 1 9 . 3 1 4}$ & $\mathbf{9 2 9 . 6 5 2}$ \\
COMERCIAL & $\mathbf{2 3 2 . 1 5 7}$ & $\mathbf{1 6 5 . 6 1 8}$ \\
VIAGENS & $\mathbf{3 4 . 6 4 1}$ & $\mathbf{2 7 . 7 0 0}$ \\
MATERIAIS & $\mathbf{9 5 . 3 1 4}$ & $\mathbf{7 8 . 9 0 3}$ \\
IMÓVEIS & 487.125 & $\mathbf{4 8 9 . 8 0 3}$ \\
PRESTAÇÃO DE SERVIÇOS & $\mathbf{2 . 1 4 0 . 8 3 9}$ & $\mathbf{2 . 5 2 8 . 7 4 9}$ \\
OUTROS IMPOSTOS E TAXAS & 150 & $\mathbf{5 3 . 8 7 5}$ \\
\hline
\end{tabular}




\begin{tabular}{ccc}
\hline TOTAL & 3.213 .426 & 4.279 .376 \\
\hline & Fonte: Softex 2019
\end{tabular}

\section{Prestação de Contas}

Os relatórios utilizados pela entidade são: o Balanço Patrimonial, a Demonstração do Resultado do Exercício, a Demonstração do Fluxo de Caixa, a Demonstração das Mutações do Patrimônio Líquido e Notas Explicativas. A prestação de contas se faz a partir das informações constantes no ERP atribuídas no projeto. As demonstrações foram apresentadas em forma comparativa, conforme a NBC TG 26 (R5). Cada demonstração e suas notas explicativas estão identificadas claramente. De acordo com a ITG 2002, no Balanço Patrimonial da Softex, a conta Capital foi substituída por Patrimônio Social e também as palavras lucro e prejuízo foram substituídas por superávit ou déficit do período. A escrituração observa os princípios da Contabilidade, como o da continuidade (intenção de continuar com a operação no futuro), oportunidade (mostram informações integras e tempestivas) e competência (registro do evento independente de recebimento ou pagamento).

Tabela 3 - Balanço Patrimonial

\begin{tabular}{|c|c|c|c|c|c|c|c|}
\hline $\begin{array}{l}\text { ATIVO } \\
\text { CIRCULANTE }\end{array}$ & $\begin{array}{l}\text { NOT } \\
\text { A }\end{array}$ & 2019 & 2018 & $\begin{array}{l}\text { PASSIVO } \\
\text { CIRCULANTE }\end{array}$ & NOTA & 2019 & 2018 \\
\hline $\begin{array}{l}\text { CAIXA E EQUIVALENTE } \\
\text { DE CAIXA }\end{array}$ & 4 & 1.320 .925 & 1.516 .194 & FORNECEDORES & & 207.982 & 120.686 \\
\hline CONTAS A RECEBER & 5 & 941.713 & 893.741 & $\begin{array}{l}\text { EMPRÉSTIMOS E } \\
\text { FINANCIAMENTOS }\end{array}$ & 7 & 198.240 & 861.085 \\
\hline $\begin{array}{l}\text { OUTRAS CONTAS A } \\
\text { RECEBER }\end{array}$ & - & 140.519 & 29.177 & $\begin{array}{l}\text { SALÁRIOS, } \\
\text { PROVISÕES E } \\
\text { ENCARGOS SOCIAIS }\end{array}$ & & 90.793 & 89.085 \\
\hline DESPESAS ANTECIPADAS & - & & 7.207 & $\begin{array}{l}\text { TRIBUTOS E } \\
\text { CONTRIBUIÇOES }\end{array}$ & & 29.639 & 32.999 \\
\hline $\begin{array}{l}\text { TOTAL DO ATIVO } \\
\text { CIRCULANTE }\end{array}$ & - & 2.402 .858 & 2.446 .319 & $\begin{array}{l}\text { PROJETOS RECURSOS } \\
\text { DE TERCEIROS }\end{array}$ & 8 & 752.418 & 995.428 \\
\hline & - & & & $\begin{array}{l}\text { TOTAL DO PASSIVO } \\
\text { CIRCULANTE }\end{array}$ & & 1.279 .073 & 2.099 .752 \\
\hline $\begin{array}{l}\text { NÃO CIRCULANTE } \\
\text { IMOBILIZADO }\end{array}$ & - & & & & & & \\
\hline NÃO CIRCULANTE & - & & & NÃO CIRCULANTE & & & \\
\hline IMOBILIZADO & 6 & 4.704 .044 & 4.950 .671 & $\begin{array}{l}\text { EMPRÉSTIMOS E } \\
\text { FINANCIAMENTOS }\end{array}$ & 7 & 70.544 & 127.187 \\
\hline $\begin{array}{l}\text { TOTAL DO ATIVO NÃO } \\
\text { CIRCULANTE }\end{array}$ & - & 4.704 .044 & 4.950 .671 & $\begin{array}{l}\text { TOTAL DO PASSIVO } \\
\text { NÃO CIRCULANTE }\end{array}$ & & 70.544 & 127.187 \\
\hline & & & & $\begin{array}{l}\text { PATRIMÔNIO } \\
\text { LÍQUIDO }\end{array}$ & & & \\
\hline
\end{tabular}




\begin{tabular}{|c|c|c|c|c|c|}
\hline & & & PATRIMÔNIO & 5.170 .051 & 5.182 .522 \\
\hline & & & \multicolumn{3}{|l|}{ SOCIAL } \\
\hline & & & SUPERÁVIT/ & \multirow[t]{3}{*}{587.234} & \multirow[t]{3}{*}{$(12.471)$} \\
\hline & & & DÉFICIT SOCIAL & & \\
\hline & & & ACUMULADO & & \\
\hline & & & TOTAL DO & \multirow[t]{3}{*}{5.757 .285} & \multirow[t]{3}{*}{5.170 .051} \\
\hline & & & PATRIMÔNIO & & \\
\hline & & & LÍQUIDO & & \\
\hline \multirow[t]{3}{*}{ TOTAL DO ATIVO } & 7.106 .902 & 7.396 .99 & TOTAL DO PASSIVO & \multirow[t]{3}{*}{7.106 .902} & \multirow[t]{3}{*}{7.396 .990} \\
\hline & & 0 & E PATRIMÔNIO & & \\
\hline & & & LÌQUIDO & & \\
\hline
\end{tabular}

Fonte: Softex 2019

Conforme Iudícibus, Marion e Faria (2009, p. 173) a demonstração do resultado confronta as receitas e despesas do período, gerando um resultado que pode ser positivo, negativo ou nulo. A tabela indica que a associação recebeu capital procedente de Convênio e Contratos de Prestação de Serviços estabelecidos com entidades governamentais. Posteriormente, na conta Custo dos Serviços Prestados, no resultado do exercício, estão incluídos os valores que foram pagos para as empresas contratadas e encarregadas pela execução dos serviços. No caso dos convênios, os valores são lançados como exigibilidades do passivo de longo prazo e não como receitas. Afora isso cada convênio é também objeto de uma auditoria especifica.

Tabela 4 - Demonstração do Resultado

\begin{tabular}{lccc}
\hline DEMONSTRATIVO & NOTA & 2019 & 2018 \\
\hline RECEITA LIQUIDA DE SERVICOS & $\mathbf{1 0}$ & 9.106 .721 & 8.534 .898 \\
CUSTO DOS SERVIÇOS PRESTADOS & $\mathbf{1 1}$ & $(4.403 .173)$ & $(3.458 .717)$ \\
SUPERÁVIT ANTES DAS DESPESAS E RESULTADO & & 4.703 .548 & 5.076 .717 \\
FINANCEIRO & & & \\
& & & $(3.213 .426)$ \\
DESPESAS GERAIS E ADMINISTRATIVAS & $\mathbf{1 2}$ & $(791.990)$ & $(669.377)$ \\
DESPESAS COM PESSOAL & & 698.132 & 127.428 \\
SUPERÁVIT DAS OPERAÇÕES ANTES DO & & & \\
RESULTADO FINANCEIRO E DOS IMPOSTOS & & 28.974 & 44.112 \\
RECEITAS FINANCEIRAS & & $(139.871)$ & $(187.175)$ \\
DESPESAS FINANCEIRAS & & 587.234 & $(15.365)$ \\
\hline SUPERÁVIT E DÉFICIT DO EXERCÍCIO & & & \\
\hline
\end{tabular}

Fonte: Softex 2019

Tabela 5 - Demonstração Das Mutações Do Patrimônio Líquido

NOTAS PATRIMÔNIO SOCIAL SUPERÁVIT/ DÉFICIT




\begin{tabular}{|c|c|c|c|c|}
\hline $\begin{array}{l}\text { SALDOS EM } 31 \text { DE } \\
\text { DEZEMBRO DE } 2017\end{array}$ & & 4.536 .460 & 646.063 & 5.182 .522 \\
\hline $\begin{array}{l}\text { AJUSTES DE } \\
\text { EXERCÍCIOS } \\
\text { ANTERIORES }\end{array}$ & 13 & & 3.164 & 3.164 \\
\hline $\begin{array}{l}\text { DÉFICIT DO } \\
\text { EXERCÍCIO }\end{array}$ & & & $(15.635)$ & (15.635) \\
\hline $\begin{array}{l}\text { ABSORÇÃO DE } \\
\text { SUPERÁVIT } \\
\text { ACUMULADO }\end{array}$ & & 646.063 & (646.063) & \\
\hline $\begin{array}{l}\text { SALDOS EM } 31 \text { DE } \\
\text { DEZEMBRO DE } 2018\end{array}$ & & 5.182 .522 & $(12.741)$ & 5.170 .051 \\
\hline $\begin{array}{l}\text { SUPERÁVIT DO } \\
\text { EXERCÍCIO }\end{array}$ & & & 587.234 & 587.234 \\
\hline $\begin{array}{l}\text { ABSORÇÃO DE } \\
\text { SUPERÁVIT } \\
\text { ACUMULADO }\end{array}$ & & (12.741) & 12.741 & \\
\hline $\begin{array}{l}\text { SALDOS EM } 31 \text { DE } \\
\text { DEZEMBRO DE } 2019\end{array}$ & & 5.170 .051 & 587.234 & 5.757 .285 \\
\hline
\end{tabular}

Fonte: Softex 2019

Tabela 6 - Demonstração do Fluxo de Caixa

\begin{tabular}{|c|c|c|}
\hline & 2019 & 2018 \\
\hline \multicolumn{3}{|l|}{ FLUXO DE CAIXA DAS ATIVIDADES OPERACIONAIS } \\
\hline DÉFICIT/ SUPERÁVIT DO EXERCÍCIO & 587.234 & $(15.635)$ \\
\hline \multicolumn{3}{|l|}{ AJUSTES PARA RECONCILIAR O SUPERÁVIT AO FLUXO DE CAIXA } \\
\hline \multicolumn{3}{|l|}{ DAS ATIVIDADES OPERCIONAIS: } \\
\hline \multirow[t]{2}{*}{ DEPRECIAÇÕES } & 320.253 & 317.725 \\
\hline & 907.487 & 302.090 \\
\hline \multicolumn{3}{|l|}{ VARIAÇÃO DE ATIVOS E PASSIVOS: } \\
\hline CONTAS A RECEBER DE CLIENTES & $(47.673)$ & $(384.601)$ \\
\hline IMPOSTOS A RECUPERAR & & - \\
\hline ADIANTAMENTOS & $(111.342)$ & 502.989 \\
\hline DESPESAS ANTECIPADAS & 7.207 & $(6.977)$ \\
\hline FORNECEDORES & 87.295 & $(4.436)$ \\
\hline OBRIGAÇÕES SOCIAIS E FISCAIS & $(2.120)$ & 39.307 \\
\hline PROJETOS DE TERCEIROS & $(243.010)$ & 862.428 \\
\hline CAIXA LÍQUIDO DAS ATIVIDADES OPERACIONAIS & 597.845 & 1.310 .800 \\
\hline FLUXO DE CAIXA DAS ATIVIDADES DE INVESTIMENTOS & $(73.626)$ & $(14.498)$ \\
\hline \multicolumn{3}{|l|}{ AUMENTO DE ATIVO IMOBILIZADO } \\
\hline CAIXA LÍQUIDO DAS ATIVIDADES DE INVESTIMENTOS & $(73.626)$ & $(14.498)$ \\
\hline FLUXO DE CAIXA DAS ATIVIDADES DE FINANCIAMENTO & $(719.488)$ & $(762.763)$ \\
\hline \multicolumn{3}{|l|}{ VARIAÇÃO NA CONTA DE EMPRÉSTIMOS } \\
\hline CAIXA LÍQUIDO DAS ATIVIDADES DE FINANCIAMENTO & $(719.488)$ & $(762.763)$ \\
\hline AUMENTO LÍQUIDO/ REDUÇÃO DE CAIXA E EQUIVALENTES DE & $(195.269)$ & 533.539 \\
\hline \multicolumn{3}{|l|}{ CAIXA } \\
\hline CAIXA E EQUIVALENTES DE CAIXA NO PERÍODO & 1.516 .194 & 982.655 \\
\hline CAIXA E EQUIVALENTES DE CAIXA NO FINAL DO PERÍODO & 1.320 .925 & 1.516 .194 \\
\hline
\end{tabular}

Fonte: Softex 2019 


\section{Notas Explicativas}

A resolução do $\mathrm{CFC} \mathrm{n}^{\circ}$ 838/00 estabelece que as entidades sem fins lucrativos podem utilizar os procedimentos das entidades sindicais e de classe, que dispõe que as notas explicativas devem incluir informações de natureza patrimonial, econômica, financeira, legal, física e social, tais como:

As principais atividades desenvolvidas pela entidade;

As práticas contábeis adotadas;

Os investimentos relevantes efetuados no período e os anteriormente existente;

A origem dos recursos relevantes;

Os detalhes dos financiamentos a longo prazo;

Os detalhes das contingências na data do encerramento do exercício, e dos prováveis efeitos futuros.

Conforme a norma a entidade detalha em suas notas explicativas todos esses processos, especificando cada ponto que precisa ser esclarecido, tais como:

Nota 1 - contexto operacional;

Nota 2 - base de elaboração e apresentação das demonstrações contábeis;

Nota 3 - resumo das principais práticas contábeis;

Nota 4 - caixa e equivalente de caixa;

Nota 5 - contas a receber;

Nota 6 - imobilizado;

Nota 7 - empréstimos e financiamentos;

Nota 8 - projetos recursos de terceiros;

Nota 9 - patrimônio social;

Nota 10 - receita liquida de serviços;

Nota 11 - custo dos serviços prestados;

Nota 12 - despesas gerais e administrativas;

Nota 13 - ajuste de exercícios anteriores.

\section{CONSIDERAÇÕES FINAIS}

O terceiro setor possui grande relevância na sociedade e por se tratar de organizações sem finalidade lucrativa existem algumas particularidades nas aplicações das práticas contábeis. Por isso é importante que o contador seja perspicaz no que se refere aos procedimentos aplicados nessas entidades. Nos últimos anos as entidades do terceiro setor 
vêm aumentando sua atuação na economia e a contabilidade se torna imprescindível para a sobrevivência destas instituições que têm a responsabilidade legal de ser transparente.

Os dados colhidos através da entrevista com o coordenador responsável mostrou que as informações contábeis da Sofitex foram apresentadas de acordo com as Normas Brasileiras de Contabilidade. A maneira coerente revela os esclarecimentos necessários para os associados e entidades governamentais. De forma isolada, os dados informados no balanço patrimonial são um pouco complexos, porém os elementos apresentados em seus relatórios auxiliares que são: a demonstração do resultado, a demonstração do fluxo de caixa, a demonstração das mutações do patrimônio líquido, bem como o controle das receitas e despesas e as notas explicativas, deixa a informação evidenciada de forma clara aos seus usuários.

Conclui-se que a Sofitex é uma entidade sólida que observa os princípios fundamentais da contabilidade e das Normas Brasileiras de Contabilidade, de maneira a promover aos seus financiadores a correta interpretação da sua condição patrimonial e financeira. E ao demonstrar as informações de forma compreensível, a entidade conseguirá maior fidedignidade e clareza de suas atividades. Afinal, uma empresa que utiliza subsídios públicos tem a obrigatoriedade de ser transparente e responsável na forma como utiliza os recursos que lhe foram confiados.

\section{REFERÊNCIAS}

BRASIL. Código civil - Lei $\mathbf{n}^{\circ} \mathbf{1 0 . 4 0 6}$ de janeiro de 2002. Disponível em: https://www.jusbrasil.com.br/topicos/10727903/artigo-44-da-lei-n-10406-de-10-de-janeirode-2002. Acesso em: 08 dez. 2020.

Decreto $\mathbf{n}^{\circ}$ 3100, de 30 de junho de 1999. Disponível em: http://www.planalto.gov.br/ccivil_03/decreto/d3100.htm. Acesso em: 22 de set. 2020.

Lei n 9.790, de março de 1999. Disponível em: http://www.planalto gov.br/ccivil_03/leis/19790.htm. Acesso em: 12 set. 2020.

Disponível

Resolução CFC. NBC T 10.8 - Entidades sindicais e associações de classe. https://www.lefisc.com.br/paginasExclusivas/terceiroSetor/conteudo/resolucoesCFC/resoluca oCFC838_99.htm. Acesso em: 12 out. 2020.

CONSELHO FEDERAL DE CONTABILIDADE. ITG (2002) - Entidade sem finalidade de lucros. Disponível em: https://www1.cfc.org.br/sisweb/SRE/docs/ITG2002(R1).pdf. Acesso em: 20 nov. 2020. 
E-DOU. Disponível em: https://e-dou.com.br/2017/06/primeiro-segundo-e-terceiro-setor/. Acesso em: 03 ago. 2020.

GRAZZIOLLI, Airton et al. Manual de procedimentos do terceiro setor: aspectos de gestão e de contabilidade para entidades de interesse social. Brasília: CFC: FBC: Profis, 2015 .

IUDÍCIBUS, Sérgio de; MARION, José Carlos; FARIA, Ana Cristina de. Introdução à Teoria da Contabilidade. 5. ed. São Paulo: Atlas. 2009.

MENEZES, Leila Soraya (Cor.). Manual de administração jurídica, contábil e financeira para organizações não-governamentais. São Paulo: Peirópolis, 2003.

OBSERVATÓRIO DO TERCEIRO SETOR. Disponível em: https://observatorio3setor.org.br/o-que-e/. Acesso em: 02 nov. 2020.

PAES, José Eduardo Sabo. Fundações e entidades de interesse social. Brasília: Brasília Jurídica, 1999.

SINIBREF - Sindicato Interestadual das Instituições Beneficentes, Religiosas e Filantrópicas dos Estados. Disponível em: http://www.sinibref-interestadual.org.br/a-importancia-dacontabilidade-para-as-organizacoes-do-terceiro-bilidade $\% 20 \mathrm{~h} \% \mathrm{C} 3 \% \mathrm{~A} 1 \% 20$ algum m\%2C\%20os. Acesso em: 10 set. 2020. 


\title{
EDUCAÇÃO ESPECIAL E INCLUSIVA EM TEMPOS DE PANDEMIA
}

\author{
https://dx.doi.org/10.48097/2674-8673.2022n6p06
}

\author{
Liliane Bastos Lins ${ }^{1}$ \\ Shirley Fernanda Gomes ${ }^{2}$ \\ Kelly Santos ${ }^{3}$
}

\begin{abstract}
RESUMO
Este trabalho apresenta uma pesquisa acadêmica que visa analisar as aulas na Educação Especial e Inclusiva durante o período de Pandemia do COVID - 19 no município de Jaboatão dos Guararapes, em Pernambuco. Quanto à metodologia, a pesquisa trata de um levantamento de dados no intuito de obter os resultados necessários para $\mathrm{o}$ desenvolvimento deste trabalho, sendo também uma pesquisa de cunho qualitativa, por buscar compreender como ocorreram as aulas da Educação Especial e Inclusiva em Jaboatão dos Guararapes. Trata-se, ainda, de uma pesquisa descritiva e exploratória quanto aos seus objetivos. Por meio desse levantamento, e também das respostas recebidas por meio de questionário virtual, foi compreendido que mesmo existindo leis que visam à inserção das crianças com deficiência nas escolas, e que essas crianças tenham uma garantia de igualdade no processo de ensino-aprendizagem, constatou-se que durante o período pandêmico, vivenciado no ano de 2020, a maior parte destes alunos não foi inclusa neste processo, visto que as aulas propostas para tal período não foi acessível, de fato, para esse alunado. Com isso, podemos afirmar que embora existam leis que obrigam o Estado a garantir uma educação igualitária para todos, na prática, ainda há uma lacuna a ser preenchida para que de fato isso ocorra.
\end{abstract}

Palavras-chave: Educação Inclusiva. Educação Especial. Pandemia.

Data de submissão: 09/09/2021

Data de aprovação: 14/10/2021

\begin{abstract}
This work presents an academic research that aims to analyze the classes in Special and Inclusive Education during the period of the COVID Pandemic - 19 in the municipality of Jaboatão dos Guararapes, in Pernambuco. As for the methodology, the research deals with a data collection in order to obtain the necessary results for the development of this work, being also a qualitative research, as it seeks to understand how the Special and Inclusive Education classes occurred in Jaboatão dos Guararapes. It is also a descriptive and exploratory research regarding its objectives. Through this survey, and also from the responses received through a virtual questionnaire, it was understood that even though

\footnotetext{
${ }^{1}$ Graduanda do Curso de Licenciatura em Pedagogia da Faculdade Metropolitana da Grande Recife.

E-mail: lilijuliabastos@gmail.com

2 Graduanda do Curso de Licenciatura em Pedagogia da Faculdade Metropolitana da Grande Recife.

E-mail: shirleyfpg81@gmail.com

${ }^{3}$ Docente Orientadora do Curso de Licenciatura em Pedagogia da Faculdade Metropolitana da Grande Recife.

E-mail:kelmelct@live.com
} 
there are laws aimed at the inclusion of children with disabilities in schools, and that these children have a guarantee of equality in the teaching-learning process, he found It should be noted that during the pandemic period, experienced in 2020, most of these students were not included in this process, since the classes proposed for such period were not, in fact, accessible to these students. With that, we can say that although there are laws that oblige the State to guarantee an egalitarian education for all, in practice, there is still a gap to be filled so that this actually happens.

Keywords: Inclusive Education. Special education. Pandemic.

\section{INTRODUÇÃO}

A Educação Especial surge no Brasil em meados do século XIX, porém de modo muito sutil, ela vem na expectativa de oferecer uma escolaridade diferenciada para pessoas com deficiência. No início do século XX surgem então as primeiras Escolas Especiais no Brasil, tendo como pioneira a "Escola dos Meninos Surdos" como era conhecida inicialmente, no ano de 1857, fundada pelo professor Ernest Huet, que se tornou surdo devido a uma infecção causada pelo sarampo. Ele desenvolveu o primeiro alfabeto Libras no Brasil, unindo seu conhecimento da Língua de Sinais Francesa ao alfabeto brasileiro.

Ao longo dos anos, através deste avanço, veio então a necessidade de inclusão das pessoas com deficiência nas escolas, mas desta vez, escolas regulares. Porém, só no ano de 1994, fala-se realmente da Educação Inclusiva, fazendo um elo com a Educação Especial, levando ao conhecimento de que educação é um direito de todos.

De acordo com o Estatuto da Criança e do Adolescente (ECA), Lei. 8.069 de 1990, o direito a um atendimento especializado às crianças com deficiência, preferencialmente na rede regular de ensino, devem ser garantidos, assim como A Lei de Diretrizes e Bases da Educação Nacional - LDB 9.394/96, no capítulo V, retrata a obrigatoriedade da inclusão dessas crianças na sala de aula regular. Contudo, a situação atual do mundo, por meio da pandemia do Covid-19, nos levou à seguinte reflexão: "existe um modo de atender as crianças com deficiência, educacionalmente, de forma remota?" Para responder tal questionamento analisaremos como a rede pública de ensino de Jaboatão dos Guararapes contemplou o acompanhamento didático e metodológico das crianças com deficiência durante a pandemia do Covid-19, no segundo semestre do ano de 2020.

No dia 06 de fevereiro de 2020, o Excelentíssimo Senhor Presidente da República, Jair Bolsonaro, decretou na Lei No 13.979, as seguintes medidas como forma de tentar conter a propagação do vírus $\mathrm{SARS}-\mathrm{Cov}-2$, que dá origem ao 
Covid-19. Art. $3^{\circ}$ Para enfrentamento da emergência de saúde pública de importância internacional decorrente do coronavírus, poderão ser adotadas, entre outras, as seguintes medidas:

I - isolamento;

II - quarentena;

Partindo desse pressuposto e tendo em vista o aumento considerável de casos da doença, o Governo do Estado de Pernambuco elaborou o Decreto de $N^{\circ} 48810$ de 16/03/2020, Art. $6^{\circ}$-A, a partir do dia 18 de março de 2020, que decretou a suspensão do funcionamento das escolas, universidades e demais estabelecimentos de ensino, público ou privado, em todo o Estado de Pernambuco.

Seguindo ainda as medidas de proteção, o Município de Jaboatão dos Guararapes, por meio do Prefeito Anderson Ferreira, emitiu um Decreto Municipal, de $\mathrm{n}^{\circ} 24$, de 16 de março de 2020, visando à suspensão:

I - de aulas e atividades em bibliotecas no âmbito da SME, a partir do dia18 de março de 2020;

II - de aulas e do uso de equipamentos públicos das academias da saúde;

$\S \mathbf{1}^{\mathbf{0}}$. Na rede privada de ensino cujos estabelecimentos estão localizados no Município do Jaboatão dos Guararapes, ficando recomendada a suspensão de aulas na educação básica, fundamental, ensino médio e superior, a partir do dia 18 de março de 2020.

Com isso, nos trouxe um quadro que nos tem sido desafiador e ao mesmotempo inovador, pois através de tal momento inoportuno e inesperado surge a necessidade de adequar a Educação Especial e Inclusiva para essa nova realidade, na qual não se podia fazer presentes num mesmo espaço físico professores e estudantes.

\section{A EDUCAÇÃO ESPECIAL NO BRASIL}

Como discutido anteriormente, percebemos o quanto a Educação Especial teve uma trajetória lenta no Brasil em relação a outros países, pois, acreditava-se que pessoas com deficiência deveriam ser "excluídas" da sociedade de certa forma. Ao longo de muitas lutas, observa-se então o avanço de pensamentos inovadores e começa-se a pensar na Educação Especial de modo isolado. A princípio, através das Escolas Especiais que eram destinadas apenas a pessoas com deficiência. Contudo, por meio de estudos feitos por grandes teóricos, surge então a necessidade de incluir essas pessoas nas unidades regulares de ensino, onde se unificou a Educação Especial 
à Inclusiva. Vygotsky (1932, p. 3) cita que: "na ausência do outro, o homem não se constrói homem", o que em outras palavras significa que todos precisam da intervenção do próximo para interagir e agregarconhecimento. A educação inclusiva tomou força no Brasil por volta dos anos 90 e se consolidou em meados de 1994, através da Declaração de Salamanca, que "define políticas, princípios e práticas da Educação Especial e influi nas Políticas Públicas de Educação”. (UNESCO, 1994, p. 3).

Segundo a Declaração de Salamanca, todas as crianças têm o direito à educação:

O princípio fundamental desta linha de ação é de que as escolas devem acolher todas as crianças independentemente de suas condições físicas, intelectuais, sociais, emocionais, linguísticas ou outras. Devem acolher crianças com deficiência e crianças bem dotadas, crianças que vivem nas ruas e que trabalham crianças de minorias lingüística, étnicas ou culturais e crianças e crianças de outros grupos ou zonas desfavoráveis ou marginalizadas. (DECLARAÇÃO DE SALAMANCA, 1994, p. 17-18).

A partir de então, tivemos um crescente avanço na Educação Especial. A Lei de Diretrizes e Base da Educação (LDB) 9.394/96, no parágrafo 58, diz que:

Entende-se por Educação Especial, para os efeitos desta Lei, a modalidade de educação escolar oferecida preferencialmente na rede regular de ensino, para educandos com deficiência, transtornos globais do desenvolvimento e altas habilidades ou superdotação. (LDB 9.394/96, Art. 58.).

Garantimos, assim, o acesso e obrigatoriedade do Estado em assistir essas crianças. Contudo, em relação à Educação Especial, ainda havia muito a ser trabalhado, como por exemplo, a verdadeira inclusão das crianças com deficiência, e foi nesse contexto que se uniu então a Educação Inclusiva, através de lutas para a inclusão de tais alunos na escola regular. Surge então a Lei Ordinária Federal n ○12.764 /2012, ou Lei Berenice Piana, nome concedido em homenagem a coautora da lei, mãe de uma criança autista e militante da causa. Essa grande ação vem nos lembrar do que falava o Pedagogo Paulo Freire (1980, p. 93): “A inclusão acontece quando se aprende com as diferenças e não com as igualdades." Para que essa inclusão aconteça, de fato, devemos viver esse pensamento em nossas atitudes ativamente.

\section{EDUCAÇÃO INCLUSIVA NO BRASIL}

Podemos dizer que o intuito de inicialização da inclusão no Brasil se deu por volta dos anos de 1857, ainda no reinado de D. Pedro I, através da fundação do “Imperial Instituto dos Surdos-mudos". Após 100 anos, veio a mudar seu nome para "Instituto Nacional de Educação de Surdos" (INES), centro de referência nacional na 
área da surdez, que foi um pontapé inicial, por assim dizer, na inclusão das pessoas com deficiência no país. É importante salientar que as escolas e classes especiais passaram a ter um elevado número de alunos com deficiência e que não necessitariam estar ali. Assim, verificou-se que a organização da Educação Especial e de classes especiais se deu em consequência da Lei 5.692/71, com a criação do Centro Nacional de Educação Especial (CENESP) e, posteriormente, a estruturação da Secretaria de Estado de Educação e do Serviço de Educação de Excepcionais, que passa a denominar-se Departamento de Ensino Especial.

Para Vygotsky (1989), a criança com deficiência tem a mesma capacidade de aprendizado e desenvolvimento que qualquer outra criançadenominada erroneamente de normal, bastando que a mesma tenha os estímulos necessários para que isso aconteça. Segundo o autor:

a essência psicológica da formação das reações condicionadas no cego (a leitura pelo sentido do tato) e no surdo (a compreensão da linguagem pelo movimento dos lábios) é absolutamente igual a da 'criança normal' e, portanto também, a natureza do processo educativo das crianças com deficiência, no essencial, é igual que na educação das 'crianças normais'. (VYGOTSKY, 1989, p. 3).

A Educação Inclusiva surgiu no Brasil com o intuito de agregar "forças" à Educação Especial, tendo em vista o contexto da Educação Especial no Brasil, que até então, se tratava de uma Educação "excludente", onde a criança com deficiência tinha o direito à Educação, porém, não tinha seu lugar na sala de aula regular, mas apenas em escolas especiais, que eram separadas por "modalidades específicas", como por exemplo, crianças autistas apenas estudariam com crianças autistas, crianças surdas apenas com crianças surdas, e assim sucessivamente. Não se pensava numa inclusão como um todo.

Conforme citação de Mazzotta (2001, p. 15):

A defesa da cidadania e do direito à educação das pessoas portadoras de deficiência é atitude muito recente em nossa sociedade. Manifestando-se através de medidas isoladas, de indivíduos ou grupos, a conquista e o reconhecimento de alguns direitos dos portadores de deficiências podem ser identificados como elementos integrantes de políticas sociais, a partir de meados deste século. (MAZZOTTA, 2001, p. 15).

Entendemos que a Educação Especial e a Educação Inclusiva andam de mãos dadas a pouco tempo. Sabemos que a perspectiva da Educação Inclusiva é que todas as pessoas tenham o direito a Educação e, para garantir o direito de todos, surge a 
obrigatoriedade da inserção desses alunos nas escolas, através da Lei de Diretrizes e Bases da Educação Brasileira(LDB) 9.634/96. Um pouco mais à frente surge a Lei Brasileira de Inclusão (LBI) $n^{\circ} 13.146 / 2015$ ou Estatuto da Pessoa com Deficiência (EPD), que institui a inclusão social e a cidadania da pessoa com deficiência, com o intuito de assegurar e promover, em condições de igualdade, o exercício dos direitos e das liberdades fundamentais.

Desse modo, podemos dizer que a modalidade da Educação Especiale Inclusiva é algo relativamente recente, e deve ser aprimorado de modo que todas as pessoas com deficiência sejam, de fato, inseridas nas unidades de ensino, assim como relata a especialista Fabiana Barrocas na Revista Construir (2020, p. 42):

Ao contrário do que se acredita, a experiência de vivenciar essa inclusão pode engrandecer tanto o aluno, quanto quem o inclui, como por exemplo, nos casos da vivência escolar, nos quais o professor pode reavaliar valores e princípios com seus alunos, ensinando e aprendendo a conviver com as diferenças. (BARROCAS, 2020, p. 42).

Somos levados a refletir, então, que a inclusão está muito além do contexto escolar, contudo, como profissionais da educação, devemos dar uma ênfase nesse tópico, pois é extremamente importante que todas as pessoas estejam inseridas na sociedade, independente de suas dificuldades, e esta inclusão pode ser facilitada por meio das diversas ferramentas tecnológicas disponíveis nos dias atuais.

\section{Tecnologias educacionais utilizadas no período de pandemia no Brasil}

É tido como Tecnologia Educacional todo o tipo de recurso utilizado para a facilitação do aprendizado. Segundo Polegatch (2013),

Entende-se por tecnologia o resultado da fusão entre ciência e técnica. O conceito de tecnologia educacional pode ser enunciado como o conjunto de procedimentos (técnicas) que visam "facilitar" os processos de ensino e aprendizagem usando a ciência. (POLEGATCH, 2013, p. 07).

Com isso, entendemos que as tecnologias podem ser desde um simples pedaço de papel e um lápis, até as tecnologias atuais e modernas, como por exemplo, a internet, os tablets, smartphones, dentre outros, e todos esses recursos podem e devem ser utilizados de maneira a inteirar as metodologias tradicionais de ensino, levando ao melhor desenvolvimento e crescimento cognitivo, interativo, motor e sensório da criança com deficiência. Contudo, vale salientar que nenhum recurso tem o poder de desenvolver por si só essas áreas, mas sim, dependem de um “intérprete”, uma pessoa 
para guiar a utilização de tais recursos, levando assim a um melhor aproveitamento das tecnologias.

No ano de 2020, especificamente no mês de março, as escolas municipais e particulares se viram obrigadas a reinventarem seus métodos educacionais devido a uma pandemia global da qual se fez necessário um distanciamento social e, consequentemente, a paralisação das aulas presenciais nas escolas e universidades. Com isso, houve então a necessidade de realizar as aulas de forma remota, levando ao uso constante de ferramentas virtuais, assim como as plataformas digitais (Google Classrom, Zoom, Hangouts, Google Meet, dentre outros). Para Rubem Alves (2016), escritor, pedagogo e filosofo brasileiro, "o professor não deve ensinar, pois os conteúdos já se encontram na internet, mas sim ensinar a pensar." A questão é: como fazer isso de forma remota?

Sabemos que o ser humano é moldado e inspirado por seu meio e não é diferente quando falamos de tecnologias, portanto, cabe a nós nos reinventarmos e nos adaptarmos a essa nova realidade. Segundo Castells (1999, p. 55), trata-se de uma revolução digital em que "a informação representa o principal ingrediente de nossa organização social, e os fluxos de mensagens e imagens entre as redes constituem o encadeamento básico de nossa estrutura social." (CASTELLS, 1999, p. 55).

A tecnologia está ao nosso redor e devemos tê-la como aliada em momentos oportunos. O processo de integração das tecnologias digitais na ação pedagógica deveria corresponder à existência de modelos pedagógicos e de currículos que dessem significado educativo ao uso das tecnologias educacionais em sala de aula e para além dela, contudo, muitos professores se encontraram desatualizados com relação às novas tecnologias e precisaram do apoio de outros profissionais.

Com a pandemia, houve o aumento considerável das ferramentas tecnológicas, contudo, nem todos os alunos têm acesso a essas tecnologias, como exemplo disso, temos os alunos das redes municipais, enfaticamente, na rede municipal de Jaboatão dos Guararapes, onde não houve aulas virtuais. Em virtude dessa condição, buscamos entender como foram contempladas as crianças deste município, especificamente as que possuem algum tipo de deficiência, visto que para elas a interação é parte fundamental de seu desenvolvimento cognitivo. 


\section{A PANDEMIA DO COVID - 19 E AS ESTRATÉGIAS DO ENSINO REMOTO}

Em meados do mês de dezembro do ano de dois mil e dezenove, foi detectado um novo vírus na China, variante do Covid, instituído como Covid - 19, que deu origem a uma nova infecção viral, o coronavírus. Ele tem a capacidade de deteriorar, em velocidade absurda, o sistema respiratório humano, comprometendo em grande maioria as pessoas com imunidade baixa ou comprometida. No início de fevereiro de 2020, mais precisamente no dia 06 de fevereiro, foi decretada a Lei de $\mathrm{n}^{\circ} \mathrm{N}^{\circ} 13.979$ para o enfrentamento do vírus no Brasil, estipulando o distanciamento social como forma de conter a expansão em massa da variante. Em 18 de março de 2020 o Governo do estado de Pernambuco decreta a Lei $N^{\circ} 48.830$ a qual proíbe as aulas presenciais no Estado, seguida do Decreto Municipal de $N^{\circ} 24$ do ano de 2020, complementando o que já havia no decreto Estadual, paralisando assim as aulas em escolas particulares ou públicas, assim como as faculdades e universidades. Houve o intuito de prevenir a saúde das crianças e professores, o que resultou em um momento inédito na educação brasileira: as aulas remotas.

Tal situação não foi previamente analisada, tendo em vista o caráter de urgência, nos levando a lacunas não preenchidas no que diz respeito à Educação Especial e Inclusiva, pois, entendemos que se faz obrigatório a inserção de alunos com deficiência na educação, como previsto na Constituição de 1988, Art. 205, Art. 206 parágrafo I, e ainda $\mathrm{Na}$ Lei De Diretrizes de Base da Educação (LBD) Lei ${ }^{\circ}$ 9.394/96.

Ainda no pensamento da educação inclusiva, podemos dizer que surge então outro grande desafio: o de consolidar o que foi garantido por lei e realizar essa integração e inclusão dentro do âmbito escolar, tendo em vista a necessidade de inserção social desse grupo que antes fora excluído da sociedade como um todo.

Contudo, devemos levar em consideração as inúmeras e inusitadas situações que podem levar ao distanciamento social do indivíduo e buscar inovações curriculares e estratégicas que façam com que esse mesmo indivíduo desenvolva cognitivamente, mesmo distante da sala de aula, buscando envolver além dos meios digitais a interação da família nesse contexto, fazendo com que não se perca tal interação, tão importante para esse desenvolvimento. Santos (2020), no seu recente trabalho "A cruel Pedagogia do Vírus" cita que a pandemia nos permite ver o modo como foi interpretado e avaliado, determinando o futuro da civilização em que vivemos. Estas aparições, ao contrário de outras, são reais e vieram para ficar. A 
pandemia é uma alegoria. (SANTOS, 2020, p. 10).

Partindo desse pressuposto, vemos que a situação atual, mesmo que inusitada e inesperada, é algo que veio para uma mudança real e permanente na área da Educação e, por mais que pareçamos despreparados, devemos nos atualizar e aprimorar todos os meios e ainda mais com relação à Educação Especial e Inclusiva, por se tratarem de crianças que na maior parte das vezes "dependem" de algum interventor, seja um professor de apoio, seja o (a) professor (a) titular, seja algum membro familiar. Eles precisam desse ponto seguro para um melhor desenvolvimento e, por essa razão, necessitam de uma atenção maior, porém, o que percebemos é que ainda estamos em defasagem quanto a esse apoio e necessitamos usar esse tempo para o amadurecimento estrutural de tais aulas, identificando a melhor forma de desenvolver um método eficaz para essa modalidade.

\section{METODOLOGIA}

Quanto aos procedimentos, este artigo utilizou-se de uma pesquisa bibliográfica, além de uma pesquisa de coleta de dados, pois se utilizou de um questionário elaborado por meio do Google Forms, destinado a 13 profissionais da área da Educação Especial e Inclusiva, no intuitode entender como se deram as aulas para crianças com deficiência na rede de ensino pública de Jaboatão dos Guararapes.

Quanto à abordagem, a pesquisa é qualitativa, pois tem o intuito de compreender como as aulas destinadas às crianças com deficiência dentro da rede municipal de ensino de Jaboatão dos Guararapes foram ministradas no período pandêmico.

Quanto aos objetivos, a pesquisa apresentada é descritiva, pois se trata de um relato documental. A pesquisa é também exploratória, pois busca enfatizar a experiência das aulas remotas no contexto da Educação Especial e Inclusiva.

Assim sendo, a partir das análises relacionadas às estratégias didáticas e metodológicas adotadas pela rede municipal de ensino no município de Jaboatão dos Guararapes, será possível compreender como as crianças com deficiência foram atendidas durante a pandemia do Covid-19.

\section{RESULTADOS}

Diante dos resultados obtidos durante a coleta de dados que tiveram base na pesquisa elaborada e direcionada aos profissionais que atuam e/ou atuaram na 
Educação Especial e Inclusiva, durante o período da pandemia do Covid - 19 em Jaboatão dos Guararapes, pudemos chegar a conclusão de que as estratégias e metodologias utilizadas no ensino especial e inclusivo foram quase que inexistentes durante o período analisado.

Há quanto tempo trabalha na Educação Especial e Inclusiva?

9 respostas

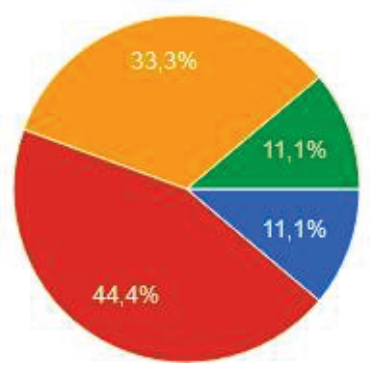

Mais ou menos 1 ano

De 2 á 5 anos

Sempre trabalhei na área

Há 15 anos

Fonte: As autoras

Tal experiência nos leva à compreensão de que esses profissionais conseguem avaliar aquilo que pode ser relevante ou não no contexto a qual foi analisado durante essa pesquisa, o que nos levou ao argumento demonstrado quando perguntado aos entrevistados: "Acredita que mesmo durante a pandemia existiu a inclusão dos alunos especiais nas salas on-line?" Observamos que a maioria respondeu que não acreditava ter existido tal inclusão durante esse período, como visualizado no gráfico abaixo:

Acredita que mesmo durante a pandemia existiu a inclusão dos alunos especiais nas salas on-line?

9 respostas

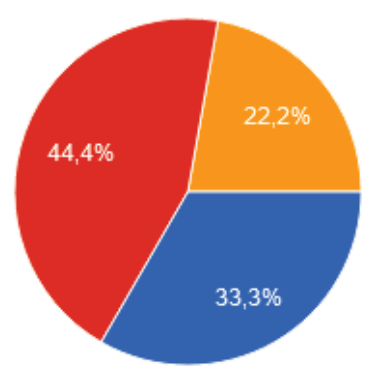


Com isso, entendemos que de fato nem todos os direitos das crianças que se enquadram na Educação Especial e Inclusiva foram contemplados. Contudo, as justificativas dadas por estes profissionais quando indagados, foram: "Uma das principais questões sobre inclusão em escolas regulares é a interação com outros estudantes". Qual a importância disso durante a pandemia? Quais ações podem ser boas práticas para garantir que os alunos com deficiência sigam tendo esses momentos com os colegas? "O profissional "X" respondeu: "Nesse momento desafiador as interações físicas entre crianças não é possível dado às questões de saúde pública”. Criar estratégias é fundamental para que isso ocorra de modo seguro. "O professor precisa desenvolver práticas pedagógicas inclusivas, possíveis para a sua práxis, viabilizando a inclusão desde já”. Penso que não há receitas, mas há ações possíveis de serem replicadas e adaptadas ao contexto".

Entendemos nessa fala que apesar de não terem a assistência necessária, as crianças da Educação Especial e Inclusiva tiveram de algum modo o pensamento voltado para suas necessidades, visando atender não somente a área educacional, como também, priorizando a saúde física de tais estudantes. Ainda no segmento das aulas durante o período pandêmico realizamos a seguinte pergunta:

\section{Com relação às aulas remotas, você acredita que houve um bom aproveitamento dos alunos com deficiência? \\ 9 respostas}
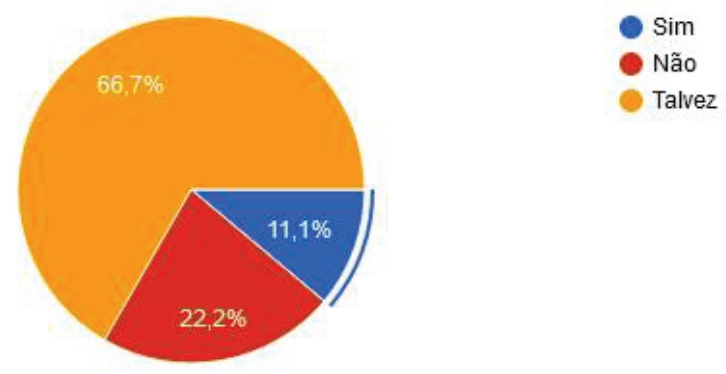

\section{Fonte: As autoras}

Embora tal mudança tenha sido planejada, ou tenha existido adaptações nas atividades propostas durante as aulas remotas da Educação Especial e Inclusiva, concluímos que os professores, auxiliares de apoio aos alunos com deficiência, psicopedagogos, não estavam totalmente preparados para essa nova realidade, sendo necessária uma reciclagem metodológica para se adaptarem ao "novo normal”. 
Sobre essa necessidade foi elaborada a seguinte pergunta: "Em sua opinião, acredita que os professores deveriam ter uma formação especializada para lidarcom as aulas remotas, virtuais, etc.? "As respostas foram representadas no gráfico abaixo:

Na sua opinião, acredita que os professores deveriam ter uma formação especializada para lidar com as aulas remotas, virtuais, etc.

9 respostas

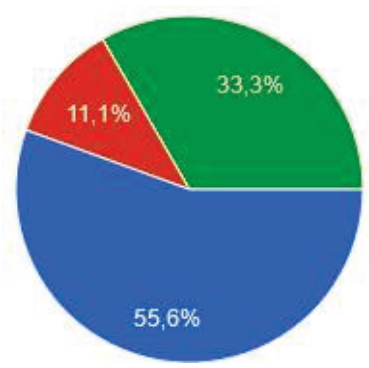

Acredito que sim

Sim , principalmente para Educação Especial e Inclusiva

- Acredito que não seja necessário, pois estamos aprendendo aos poucos

Sim, para todos os âmbitos

educacionais

Fonte: As autoras

Percebemos por meio das respostas dos entrevistados que 55,6\% deles acreditam que deveria existir uma formação especializada direcionada para os profissionais que lidam com a educação, principalmente a Especial e Inclusiva, para que consigam adaptar às atividades e metodologias de ensino de modo a contemplar tal modalidade educacional.

Contudo, esse envolvimento e desenvoltura não dependem apenas da rede de ensino, mas também de todos os envolvidos. Diante de tal questionamento abordamos os entrevistados com a seguinte indagação: "Em sua opinião, a ação do professor (a) durante o período de pandemia, necessita mais do apoio dos pais ou responsáveis pela criança? De que modo?" Obtivemos do profissional "Y" a seguinte resposta: "Sim, a participação da família é fundamental no desenvolvimento do aluno. Ela sabe quais atividades ela tem competência pra desenvolver e o auxiliar." Do profissional " $X$ " foi dada a seguinte resposta ao mesmo questionamento: "A participação das famílias é sempre bem vinda, pois está sendo o nosso suporte nesse momento."

Ainda no contexto de apoio escolar para a Educação Especial e Inclusiva durante a pandemia argumentamos o seguinte:

Você obteve ajuda de mais algum profissional ao desenvolver as atividades para os alunos especiais? De que modo?

O profissional “z” respondeu: "na nossa formação continuada já temos 
orientações nas adaptações". E o profissional "W" respondeu: "sempre trabalhamos com adaptações de materiais para melhorar o atendimento". E ainda o profissional "y" respondeu: "sim, o psicólogo". Levando a compreensão de que todo trabalho desenvolvido é destinado às crianças com deficiência deve ser realizado em conjunto, buscando assim um melhor aproveitamento, ainda mais durante períodos de distanciamento como o vivido atualmente. Compreendemos que a família ou responsável pela criança tem fundamental importância em seu desempenho escolar, seja ela por meio presencial ou virtual, porém temos nesse ponto mais uma grande dificuldade: a desigualdade social. Acreditamos ser um dos fatores influenciadores da falta de aprofundamento e desenvolvimento de atividades que englobassem todos os alunos, de forma inclusiva como deveria ser, já que grande parte, se não toda a sociedade escolar da rede municipal, vem de uma situação social onde não existe sequer acesso à internet, o que consideramos, no momento, um instrumento principal de comunicação entre escola e estudante e sem esse recurso as aulas remotasde fato não têm como existir, ou seja, mais uma vez, de certo modo, as crianças com deficiência têm seu direito negado por não haver uma estratégia, seja ela causada pela negligência de uma das partes. Sobre esse argumento realizamos a seguinte pergunta:

E quanto às escolas municipais, acredita que tenham tido êxito no desenvolvimento das aulas remotas direcionadas ás crianças deficientes?

9 respostas

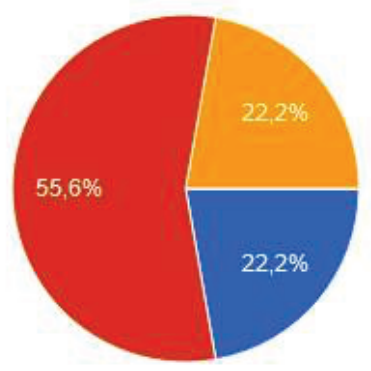

Não houve qualquer desenvolvimento Sim, porém não totalmente

- Acredito que foram atendidas conforme a necessidade de cada especificidade

Sim, houve de fato uma atenção para educação especial e Inclusiva durante a pandemia

\section{Fonte: As autoras}

Nesse caso, é visto que existe sim um despreparo a ser reparado, a fim de fazer valer os direitos garantidos por lei. A Lei de Diretrizes e Bases da Educação Nacional (LDB), no 9.394/96, no Capítulo III, art. $4^{\circ}$, inciso III, diz que é dever do Estado garantir o "atendimento educacional especializado gratuito aos educandos com necessidades especiais, preferencialmente na rede regular de ensino". E para que isso seja garantido, de fato, deve-se haver uma mudança integral na rede de ensino, para 
que o acesso seja permitido a todos os estudantes de forma a garantir a equidade.

Por fim, segue abaixo um quadro sobre os pontos positivos e negativos encontrados por meio desta pesquisa durante o período pandêmico.

\begin{tabular}{|c|c|}
\hline $\begin{array}{l}\text { Pontos positivos } \\
\text { observados durante o } \\
\text { periodo de pandemia na } \\
\text { Educaça Especial e } \\
\text { Inclusiva. }\end{array}$ & $\begin{array}{l}\text { Pontos negativos } \\
\text { observados durante o } \\
\text { periodo de pandemia na } \\
\text { Educaçáo Especial e } \\
\text { Inclusiva. }\end{array}$ \\
\hline A prioridade a vida. & $\begin{array}{l}\text { A Falta de planejamento e } \\
\text { metodologias que } \\
\text { atendessem as } \\
\text { necessidades das crianças } \\
\text { da Educação Especial e } \\
\text { Inclusiva. }\end{array}$ \\
\hline
\end{tabular}

Fonte: as autoras

Entendemos que o maior ponto positivo, sem dúvidas, foi a prioridade da vida, em todos os âmbitos, porém, os pontos negativos observados, ainda através da pesquisa, foi a falta de um planejamento eficaz à Educação Especial e Inclusiva, assim como a utilização das metodologias que atendessem às necessidades do público proposto.

\section{CONSIDERAÇÕES FINAIS}

Considerando os resultados de pesquisa, podemos concluir que diante das dificuldades enfrentadas durante o período da Pandemia do Covid-19 no município de Jaboatão dos Guararapes existiram divergências entre os planejamentos e execuções de métodos de ensino que fossem realmente eficazes diante de tal contexto. Por meio das respostas obtidas pelo questionário, percebemos ainda que não houve sequer um apoio maior da parte da Secretaria de Educação da rede municipal de Jaboatão dos Guararapes com relação às aulas durante o período de pandemia, levando o(a) professor(a) a ausência de recursos apropriados para a elaboração e execução de atividades ou aulas remotas que preenchessem esse espaço tão necessário.

Percebeu-se ainda que diversos fatores que contribuíram para que essa inclusão não fosse garantida, mesmo que por lei ela exista. Como exemplo disso tem a falta de recursos dos alunos em relação aos meios acessíveis de uma possível aula on-line. Devemos nos atentar às necessidades desses alunos e tentar da melhor forma fazer valer seus direitos como o de qualquer estudante. Ainda que em meio a uma pandemia, essa inclusão precisa ser validada e cumprida.

Não podemos deixar de enfatizar que a prioridade sempre será a vidae, nesse momento de pandemia, é nisso que devemos focar. Ainda assim, tudo o que foi enfrentado durante o período da pandemia no novo coronavírus, serviu para nos 
atentarmos às mudanças que necessitamser realizadas no âmbito educacional. Mudanças essas que devem ser pensadas para utilização tanto em momentos como o que estamos enfrentando, quanto momentos futuros, onde estudantes necessitem ter acesso às aulas de forma virtual em decorrência das suas comorbidades e ainda assim ter seu direito a educação assegurado de forma efetiva e não apenas na lei. Que possamos, diante desse enfrentamento, tirar lições para toda a vida.

\section{REFERÊNCIAS}

BELLONI, Maria Luiza; GOMES, Nilza Godoy. Infância, mídias e aprendizagem: autodidaxia e colaboração. Educ. Soc., Campinas, vol. 29, n. 104 - Especial p. 717746, outubro 2008. Disponível em: http://www.cedes.unicamp.br. Acesso em: 20 abr, 2021.

BRASIL. Estatuto da Criança e do Adolescente (ECA). Lei 8.069 de 13 de julho de 1990.

BRASIL. Leis de Diretrizes e Bases da Educação Brasileira (LDB). Lei 9.394 de 20 de dezembro de 1996.

CASTELLS, Manuel. A sociedade em rede. São Paulo: Paz e Terra, 1999.

DECLARAÇÃO DE SALAMANCA. Princípios, Políticas e Práticas na Área das Necessidades Educativas Especiais. A/RES/48/96, Resolução das Nações Unidas adotada em Assembléia Geral.

FARAH, Fabiana Barrocas Alves; Notícias Construir. Ed. Construir. Recife, Março de 2020.

FREIRE, Paulo. Pedagogia do oprimido. 8. ed. Rio de Janeiro: Paz e Terra, 1980.

MAZZOTTA, Marcos J. S. Educação Especial no Brasil - História e políticas públicas. 3. ed. São Paulo: Cortez, 2001.

MERCÚRIO, Regina. Disponível em: https://educacaointegral.org.br/reportagens. Acesso em : 20 abr. 2021.

MOREIRA, Marco Antônio. Teorias de Aprendizagens. EPU, São Paulo, 1995. Disponível em: https://www.infoescola.com/pedagogia/teoria-de-aprendizagemde-vygotsky/. Acesso em: 20 out. 2020.

POLEGATCH. Estudo sobre as Tecnologias Educacionais. Pós Graduação em Língua Espanhola. Universidade Tuiuti Do Paraná. Curitiba, 2013.

RUBEM ALVES. Disponível em: https://blogs.funiber.org/pt/formacaoprofessores/2016/09/20/funiber-rubem-alves-pensar. Acesso em: 02 abr. 2021. 
SANTOS, Boaventura de Sousa. A cruel pedagogia do vírus. Coimbra: Edições Almedina, 2020.

SHUARE, M. La psicologia soviética tal como yo la veo. Moscú: Editorial Progreso, 1990.

UNESCO. Disponível em: https://brasil.un.org/. Acesso em: 05 abr. 2021.

VYGOTSKY, L. S. Fundamentos de defectologia. La Habana: Pueblo y Educación, 1989. 


\section{APENDICE A - Questionário aplicado na pesquisa de campo}

\section{Pesquisa Acadêmica}

Pesquisa para trabalho de conclusão de curso

Uma das principais questões sobre inclusão em escolas regulares é a interação com outros estudantes. Qual a importância disso durante a pandemia? Quais ações podem ser boas práticas para garantir que os alunos com deficiência sigam tendo esses momentos com os colegas?

Texto de resposta longa

teve um bom recebimento devolutivo de familiares ou responsáveis por alunos com deficiência * sobre as atividades enviadas para casa?

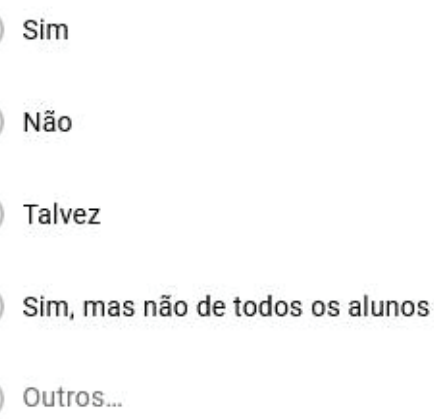

:::

Na sua opinião, a ação do professor (a) durante o periodo de pandemia, necessita mais do apoio dos pais ou responsáveis pela criança? De que modo?

Texto de resposta longa

presencial considerando o tempo distante da escola e dos colegas?

Texto de resposta longa

Quais lições você tirou de todo o período em que as aulas foram suspensas por conta do distanciamento social? 
Há quanto tempo trabalha na Educação Especial e Inclusiva? *
Mais ou menos 1 ano
De 2 á 5 anos
Sempre trabalhei na área
Outros...

Qual o maior desafio você enfrentou com a pandemia no âmbito educacional? *

Texto de resposta longa

Com relação às aulas remotas, você acredita que houve um bom aproveitamento dos alunos com deficiência?

Sim

Não

Talvez

Outros...

De que forma você acha que as aulas remotas funcionariam melhor no que diz respeito a Educação Especial e Inclusiva?

Texto de resposta longa

Você obteve ajuda de mais algum profissional ao desenvolver as atividades para os alunos especiais? De que modo?

Texto de resposta longa 


\title{
FATORES MOTIVACIONAIS EM UMA EMPRESA DO SEGMENTO COMERCIAL NA CIDADE DE RECIFE
}

\author{
https://dx.doi.org/10.48097/2674-8673.2022n6p07
}

\author{
Natália Batista Lins ${ }^{1}$ \\ Nayana Júlia dos Santos Bandeira² \\ João Biron de Oliveira Filho ${ }^{3}$ \\ Eronildo Ferreira do Carmo ${ }^{4}$
}

\section{RESUMO}

Este trabalho trata de algumas variáveis inerentes à motivação dos indivíduos no ambiente de trabalho e do incentivo aos colaboradores no processo produtivo que conduz a resultados positivos. Mediante pesquisa realizada na empresa Padeirão Food Service, localizada na cidade de Recife-PE, pretende-se mostrar a importância da criação de um ambiente propício à motivação que gere, consequentemente, inovação nas organizações. Em relação à apresentação dos resultados da pesquisa, optou-se por dar maior ênfase à importância da motivação dentro da empresa como fonte de inovação, uma vez que os fatos aqui relatados mostram efetivamente a inexistência de um processo motivacional que incentive os colaboradores da organização.

Palavras-chave: Clima Organizacional. Motivação. Níveis Motivacionais.

Data de submissão: 12/08/2021

Data de aprovação: 14/09/2021

\begin{abstract}
This work deals with some variables inherent to the motivation of individuals in the work environment and the encouragement of employees in the production process that leads to positive results. Through research carried out at Padeirão Food Service, located in the city of Recife-PE, it is intended to show the importance of creating an environment conducive to motivation that generates, consequently, innovation in organizations. Regarding the presentation of the research results, it was decided to give greater emphasis to the importance of motivation within the company as a source of innovation, since the facts reported here effectively show the inexistence of a motivational process that encourages the organization's employees.
\end{abstract}

\footnotetext{
${ }^{1}$ Concluinte do Curso de Pós-graduação em Psicologia Organizacional e do Trabalho da FMGR. E-mail: natalia-lins@live.com

${ }^{2}$ Concluinte do Curso de Pós-graduação em Psicologia Organizacional e do Trabalho da FMGR. E-mail: nayana.julia12@gmail.com

${ }^{3}$ Docente orientador do Curso de Pós-graduação em Gestão da Psicologia Organizacional e do Trabalho da FMGR. E-mail: joaobiron@gmail.com

${ }^{4}$ Docente coorientador do Curso de Pós-graduação em Gestão da Psicologia Organizacional e do Trabalho da FMGR. E-mail: proferon100@gmail.com
} 
Keywords: Organizational Climate. Motivation. Motivational Levels.

\section{INTRODUÇÃO}

A motivação é um dos principais fatores para o comportamento das pessoas em uma empresa. Caso elas não estejam com boa autoestima nada irá fazer com que desempenhem suas atividades de forma eficaz. Em todas as empresas há gerentes, chefes, gestores. Apesar do nome, todos têm o papel de ser líder, ou seja, orientar as pessoas que estão ao seu redor para que elas busquem o melhor resultado em um lugar onde há várias incertezas.

Organização e maximização de lucros são evidentes sobre quaisquer outros objetivos da empresa e muitos defendem o uso de formas de controlar os subalternos a fim de predeterminar o nível de produtividade. Entende-se que a melhor forma de incentivar a motivação é substituir a punição pela remuneração. Dessa maneira, os trabalhadores escolheriam o trabalho pela perspectiva de remuneração e não pelo cargo ou tipo de trabalho. A abordagem dada à ação de equilíbrio pelo bom desempenho torna-se tão intensa que a satisfação a ser conquistada pelo trabalho passa a ser a própria motivação para executá-lo. (FERREIRA, 2001).

Muitos teóricos sugerem um sistema de recompensa/punição, entretanto, nesse ambiente de trabalho, com produtividade máxima, os colaboradores perceberam que estavam correndo risco na sua própria segurança no trabalho. Receberiam maior remuneração, porém haveria um número bem mais reduzido de funcionários para a mesma produtividade.

Conforme cita Ferreira (2001), outra proposta é adotar e defender uma postura administrativa que visa à importância da pessoa na sua plenitude. A melhor forma de motivar os trabalhadores seria dando importância às características sociais dos mesmos. As organizações começariam a mostrar aos funcionários a sua importância pessoal no trabalho. Dessa forma, eles iriam se sentir úteis e também motivados. Essa estratégia visa avivar os valores pessoais e satisfazer as necessidades sociais.

Outra visão de trabalho é quanto à necessidade de satisfazer os desejos naturais dos colaboradores, visando à integração em determinado grupo social sem que fosse jamais esquecido o valor individual. Essas necessidades foram consideradas tão importantes que substituíram com vantagens as recompensas em pecúnia. A manipulação das pessoas continuou, embora de um modo bem diferente. Afinal, caberia aos supervisores demonstrar sua preocupação e simpatia para com as necessidades, desejos e problemas dos seus subordinados.

Os canais de comunicação, tanto no sentido ascendente como descendente, passaram a 
ser valorizados. A partir desse novo modelo de compreensão do ser humano em situações de trabalho, os funcionários deveriam conhecer tudo aquilo que diz respeito à organização, tendo abertura para expor suas ideias para com as estratégias produtivas, de acordo com as diretrizes administrativas da organização. Dessa forma, consequentemente, os esforços e recompensas deixariam de ser individuais e passariam a ser grupais.

Esses trabalhadores são vistos como pessoas que possuem diferentes habilidades e talentos que são próprios, tendo condições de contribuir da sua maneira para a consecução dos objetivos organizacionais, cabendo à administração buscar meios para desbloquear a saída de tais recursos para que se transformem em ações eficazes e produtivas.

Reconhece-se que cada um já traz de alguma forma dentro de si suas próprias motivações. As organizações devem ser capazes de não sufocar as forças motivacionais inerentes às próprias pessoas de tal forma que elas não percam sua sinergia motivacional.

Esse trabalho tem a finalidade de avaliar os fatores motivacionais, tais como remuneração e benefícios, desempenhados na empresa Padeirão Food Service, buscando saber como a organização está segurando o seu capital humano.

\section{REFERENCIAL TEÓRICO}

\section{Histórico e Conceito de Motivação}

A motivação procura explicar o porquê do comportamento das pessoas e de acordo com Maximiano (2010) indica as causas ou motivos que produzem determinado comportamento, seja ele qual for, e que está baseada em três propriedades: direção (para onde a motivação leva o comportamento), intensidade (amplitude da motivação) e a permanência (duração da motivação).

A Administração Científica baseava-se na concepção do homo economicus, segundo o qual o comportamento do homem é motivado exclusivamente pela busca do dinheiro e pelas recompensas salariais e materiais do trabalho, onde ele pretende maximizar seus rendimentos e cujos princípios se basearam na estrutura formal e nos processos das organizações.

Toda a abordagem clássica da administração se baseava nessa estreita teoria da motivação. O experimento de Hawthorne foi um dos eventos mais importantes na história do enfoque comportamental na administração, realizado entre 1927 e 1933, e depois fez parte de um programa mais amplo, orientado pelo professor Elton Mayo, que durou até 1947. Elton Mayo (1933, apud MAXIMIANO, 2010) e sua equipe demonstraram uma teoria da motivação contrária à do homo economicus, onde o ser humano é motivado, não por estímulos 
salariais e econômicos, mas por recompensas sociais e simbólicas, pois a recompensa salarial não é o único fator decisivo que motiva o trabalhador dentro da organização. São muitos os meios de reconhecer e valorizar o comportamento positivo das pessoas, oferecendo desafios e desenvolvendo programas de reconhecimento instantâneo, como por exemplo, brindes, um dia de folga, um mês de estacionamento grátis, entre outros.

\section{Motivação no Ambiente Organizacional}

Nos dias atuais o tema "motivação" tem sido cada vez mais discutido, pois as empresas têm mostrado cada vez mais a necessidade nessa questão. Isso se deve a esse mundo cada vez mais agitado, consequência de um capitalismo cada vez mais severo. Essa concorrência está deixando as pessoas ainda mais assustadas, pois o mercado de trabalho vem oferecendo menos oportunidades. A situação se complica quando o candidato não apresenta uma qualificação compatível a uma função almejada.

$\mathrm{Na}$ busca de tentar entender um pouco sobre o assunto, é importante saber o conceito dessa palavra que tanto se fala, mas poucos a valorizam. Não há apenas um único nome que defina motivação, pois sua definição é muito complexa. A própria denominação sugere ser um motivo para uma ação. Motivo este que está relacionado ao aspecto psicológico de cada individuo. Alguns autores a definem como causa de um comportamento ou conjunto de forças internas que orientam a conduta de um indivíduo para determinado objetivo ou um processo psicológico que leva uma pessoa a fazer esforços para obter determinado resultado.

A motivação humana é complexa e por isso tem se tornado uma área de bastante preocupação na teoria e práticas administrativa. Essa preocupação consiste na busca de uma relação mais satisfatória entre o colaborador e a organização. A motivação é uma força interior propulsora, de importância decisiva no desenvolvimento do ser humano. Assim como na aprendizagem em geral, o ato de aprender algo é ativo e não passivo.

Baseado nos conceitos sobre motivação que foram relacionados nesse estudo, definimos motivação como fatores impulsionadores que nos levam a determinadas ações. Na perspectiva organizacional, motivar é incentivar pessoas e equipes a trabalhar da melhor maneira possível através da construção de um ambiente favorável ao desempenho de suas aptidões. (CHIAVENATO, 2004).

No decorrer desse estudo são apresentadas diversas teorias de diferentes autores, as quais apontam diversos fatores que podem os motivar. Entende-se que nenhum fator por si só é capaz de motivar totalmente o individuo, principalmente porque os motivos humanos variam de pessoa para pessoa, e até mesmo de um momento para outro da mesma pessoa. Sendo 
assim uma tarefa difícil, pois o comportamento é extremamente complexo, devido às diferenças individuais e devido ao fato de as pessoas mudarem continuamente.

Observando a complexidade e importância da motivação nas organizações atual e devido a sua influência nos resultados os executivos e chefes gostariam de ver seus funcionários motivados e integrados com os objetivos da empresa de forma a atingir o máximo de produtividade. Os indivíduos se tornam um meio para a busca dos fins definidos pela organização devido ao uso de padrões organizacionais de motivação da mesma. Afinal, um profissional motivado produz muito mais. (CHIAVENATO, 2004).

\section{Níveis de Motivação}

Existem três níveis de motivação para cada indivíduo:

1) Nível semântico (os significados)

O que motiva o indivíduo é apenas aquilo que tem para ele algum significado pessoal, seja qual for o significado que esse indivíduo lhe atribui. O indivíduo move-se pelos instintos que nascem da sua individual valoração positiva ou negativa, procurando os objetivos aos quais agregou à primeira e distanciando-se dos objetivos aos quais agregou à segunda. $\mathrm{O}$ indivíduo diz-se centrado em si mesmo, isto é, na sua única e própria esfera de valorações.

\section{2) Nível cognitivo (da aprendizagem)}

Para um indivíduo plenamente receptivo a todos os estímulos que capta do seu ambiente (exterior e interior), há um descentramento da sua rede de entidade valorativas. A valoração já não reside em si, mas apenas no prazer que pode extrair da aprendizagem do que lhe é exterior e do que lhe é interior. Não existe um objeto que lhe seja desinteressante. Tudo é considerado interessante e passível de ser conhecido por vontade própria. Estes indivíduos podem experimentar um sentimento de ligação mística com o universo de estímulos que se lhes apresenta. Porém, podem também sofrer de uma incapacidade na definição precisa e concreta de um único objetivo ou meta face à sua valoração. $\mathrm{O}$ seu pensamento divergente $\mathrm{e}$ extremamente fluido pode levar a uma dispersão da sua atenção e à incapacidade de realização concreta de qualquer tarefa a que se proponham.

\section{3) Nível existencial (do ato)}

Para um indivíduo ultrapassar esse primeiro momento de dispersão da sua atenção mediante todos os estímulos que existem no meio, existe a consciência de que não é possível 
conhecer todos os estímulos que se nos apresentam. As causas são óbvias: a quantidade de estímulos recebida por instante é muito superior à capacidade perceptiva humana. Interpretar cada um desses estímulos requer grandes intervalos de tempo, e, portanto, elaborar respostas a cada um desses estímulos também não é humanamente possível. A vida humana é limitada pelo nascimento e morte, sendo demasiado pequena para receber, interpretar e responder a todos os estímulos. Para o indivíduo que chega a esta inevitável conclusão, só é possível um caminho: dentre todos os estímulos existentes, escolher interpretar e responder apenas àqueles que permitem um maior e mais rápido desenvolvimento da sua personalidade.

Hoje em dia, a grande maioria das pessoas não passa do nível semântico, o mais centrado de todos. Daí decorre que a vida, atualmente, seja, sobretudo, uma luta pela sobrevivência. Para as pessoas que atingiram o nível cognitivo, a vida não é nada fácil, dado que a maioria das pessoas não passa do nível semântico e, portanto, se atropelam mutuamente para satisfazer os seus instintos. Estima-se que a maior parte das pessoas que reside no nível cognitivo não sobreviva facilmente, sendo selecionadas negativamente. Tanto maior é esta seleção negativa quando maior e mais completa for a capacidade perceptiva da pessoa, isto é, quanto maior for a sua inteligência. Daí decorre que grande parte das pessoas mais inteligentes do mundo está a ser selecionada negativamente. Em raríssimos casos, existe uma pessoa que passa para o nível existencial.

\section{Fatores Motivacionais Predominantes na Empresa Padeirão Food Service}

As organizações e o trabalho estão incluídos na vida dos seres humanos desde a sua criação. Lidar com pessoas nas organizações tem sido uma responsabilidade que, atualmente, se reveste de uma complexidade muito maior do que há poucos anos atrás. De alguma forma, todos estamos ligados a uma organização de forma direta ou indireta. E se por algum motivo não estão desempenhando o seu trabalho da melhor maneira possível cabe aos profissionais da área observar o que está acontecendo e buscar soluções adequadas para resolver.

Para Lacombe (2005), as pessoas são os atores das organizações. São elas que tomam as decisões em nome das melhorias desejadas. São também agentes econômicos que têm como objetivo maximizar sua satisfação. Portanto, as atividades econômicas e administrativas são conduzidas por pessoas, que procuram satisfazer suas necessidades, desejos e até mesmo seus caprichos e, se essas pessoas não estiverem motivadas, seus resultados talvez não atinjam os objetivos desejados por todos.

Algum tempo atrás as cooperativas não se preocupavam com o relacionamento interno e externo de seus funcionários. Hoje em dia essa prática vem mudando aos poucos. As 
cooperativas passaram a perceber que o funcionário que trabalha motivado rende muito mais para a organização, portanto, com o passar dos anos alguns esforços vêm sendo feitos no sentido de melhorar a qualidade e em consequência dessa melhoria vem a satisfação das pessoas que fazem parte da organização. Um exemplo desse esforço é como as organizações estão conduzindo seu pessoal. A cada dia elas estão introduzindo em sua estrutura profissionais qualificados que, através de suas habilidades, têm a capacidade de visualizar a organização dentro de seu ambiente externo e compreender a força de seu pessoal.

Segundo Lacombe (2005), todo administrador é responsável pelo desempenho de sua equipe. Assim, da mesma forma que a equipe deve ser formada e renovada em função dos planos estratégicos da empresa, sua condução deve ter como objetivo alcançar as metas previstas naquele plano. A melhor maneira de obter resultados por meio da equipe e até mesmo superá-los é comprometê-la com as metas, desafios e, até mesmo, riscos. Toda cooperativa tem suas metas para cada período, portanto, para alcançar o desejado, toda a equipe tem que estar comprometida e motivada para desempenhar seu papel da melhor forma. Se o administrador souber cativar seu pessoal e mostrar as vantagens o desempenho das tarefas poderá ser bem melhor. Segundo Ribeiro (2006, p. 4), "administrar com as pessoas significa tocar a organização juntamente com os colaboradores e os parceiros internos que mais entendam dela e de seu futuro".

Para que uma organização obtenha um bom clima organizacional é fundamental que os donos de empresas e gerentes ouçam seus funcionários individualmente para que descubram o que lhes motiva, e também comecem a enxergar seus colaboradores não só como meio de produção, mas sim como pessoas que querem crescer junto com a organização, oferecendo condições de trabalho adequadas, dando-lhes estímulos e sempre tratando todo funcionário com muito respeito.

A motivação dentro de uma organização é essencial para que possamos sempre manter em equilíbrio tudo que nos faz obter sucesso e vitórias. Se permanecermos com funcionários motivados, podemos ter a absoluta certeza que, consequentemente, nossos clientes serão reflexos de nossos funcionários, pois estarão adquirindo toda a motivação que temos dentro de nossa empresa.

É necessário que o empresário enxergue em cada funcionário um ser humano como qualquer outro, cheio de sonhos e desejos de realização, para que possam além de dar-lhes estímulos motivacionais, recompensas pelo seu desempenho, tornando-os parte das empresas, mostrando o quanto são importantes para a produtividade da organização. 
Com o funcionário motivado, os empresários e gerentes podem sempre estar tranquilos em relação à importância e responsabilidade que o colaborador tem com a empresa, com a produção e com a satisfação dele em estar ali, exercendo tais tarefas.

\section{METODOLOGIA}

A pesquisa, em relação ao tema abordado, é de natureza qualitativa e quantitativa. $\mathrm{O}$ método quantitativo e a amostra da pesquisa são os dados obtidos através de um questionário específico para alcançar o resultado mais verdadeiro possível. O método quantitativo representa, em princípio, a intenção de garantir a precisão dos resultados, evitar distorções de análise e interpretação, por isso à escolha desse método. A pesquisa teve como base um estudo de caso quanto ao aspecto motivacional dos colaboradores da empresa Padeirão Food Service.

A pesquisa de campo teve como alvo os funcionários da organização citada. Cinquenta colaboradores foram entrevistados. Os dados foram coletados através de um questionário que buscou compreender os fatores motivacionais externos e internos que podem influenciar na motivação destes colaboradores. Foi aplicado diretamente e de forma aleatória um questionário que era composto de questões fechadas com múltiplas escolhas. O objetivo foi analisar a motivação e a satisfação dos cooperados a respeito de sua satisfação em vários aspectos como saúde, segurança, reconhecimento, relacionamento, entre outros.

\section{ANÁLISE E INTERPRETAÇÃO DOS DADOS}

A pesquisa foi elaborada com o objetivo de verificar como os colaboradores se sentem com relação à organização que trabalha, visando melhor compreensão sobre o assunto abordado. Ao analisar cada gráfico a seguir, a proposta é que o entendimento sobre o assunto fique mais claro e objetivo.

De acordo com os dados coletados, foi possível verificar que motivar é algo que vem de dentro. Todos têm objetivos a serem conquistados, ou seja, motivos ou razões para levantar cedo e ir trabalhar. Mas como anda o nível de motivação, de acordo com a pesquisa realizada? 
Gráfico 1 - Qual o nível de motivação para ir ao trabalho?

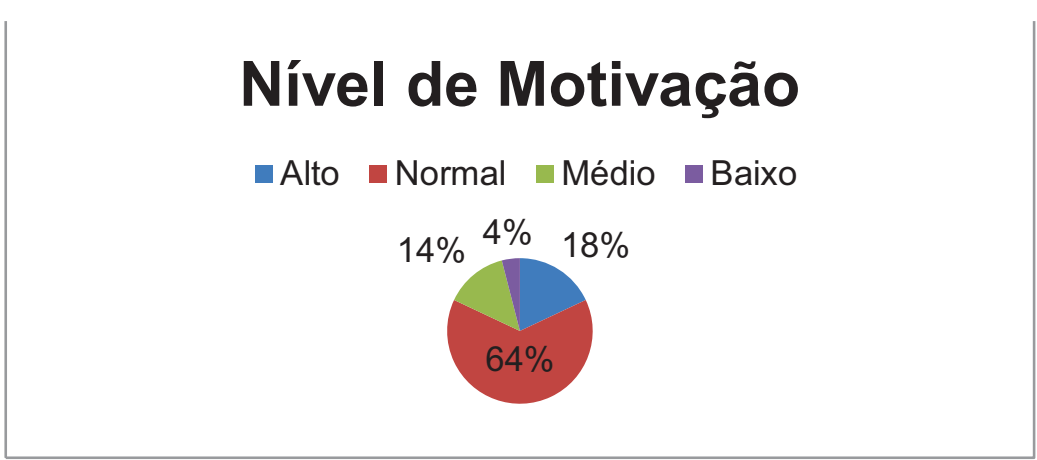

Fonte: os autores (2020)

Um líder tem habilidade de incentivar as pessoas a fazer aquilo que deve ser feito. Quanto à consideração ao colega de trabalho, os líderes precisam entender que sozinhos podem cumprir metas, mas com sua equipe motivada, ultrapassa todas as expectativas. $\mathrm{O}$ gráfico abaixo mostra o resultado da seguinte pergunta: "você recebe reconhecimento pelo seu líder quando um trabalho é bem executado"? O resultado mostra que 90\% dos colaboradores recebem reconhecimento do seu líder, o que pode ser um fator de motivação para alguns deles. Quando se é parabenizado ou reconhecido por um trabalho executado, só incentiva a melhorar.

Gráfico 2 - Você recebe reconhecimento pelo seu líder quando um trabalho é bem executado?

\section{Reconhecimento pelo seu líder}

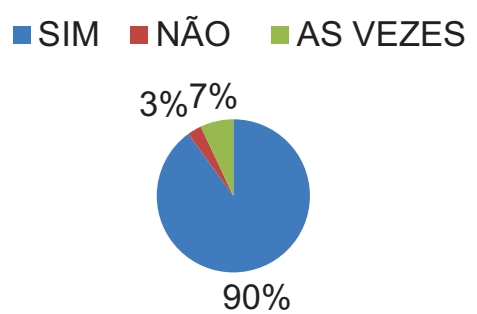

\section{Fonte: os autores}

Foi possível verificar que um dos principais fatores motivacionais nessa empresa, com cerca de 58\%, são a relações pessoais no ambiente de trabalho. As relações com os colegas e chefes são importantes, tornando um clima organizacional propício de produtividade, em que a colaboração e a solidariedade estejam presentes no cotidiano, tornando os dias mais agradáveis. 
O gráfico abaixo mostra o resultado da seguinte pergunta: "o que motiva o colaborador a trabalhar nessa organização"? A motivação dentro de uma organização é essencial para que possamos sempre manter em equilíbrio tudo que nos faz obter sucesso e vitórias.

Gráfico 3 - O que motiva o colaborador a trabalhar nesta organização?

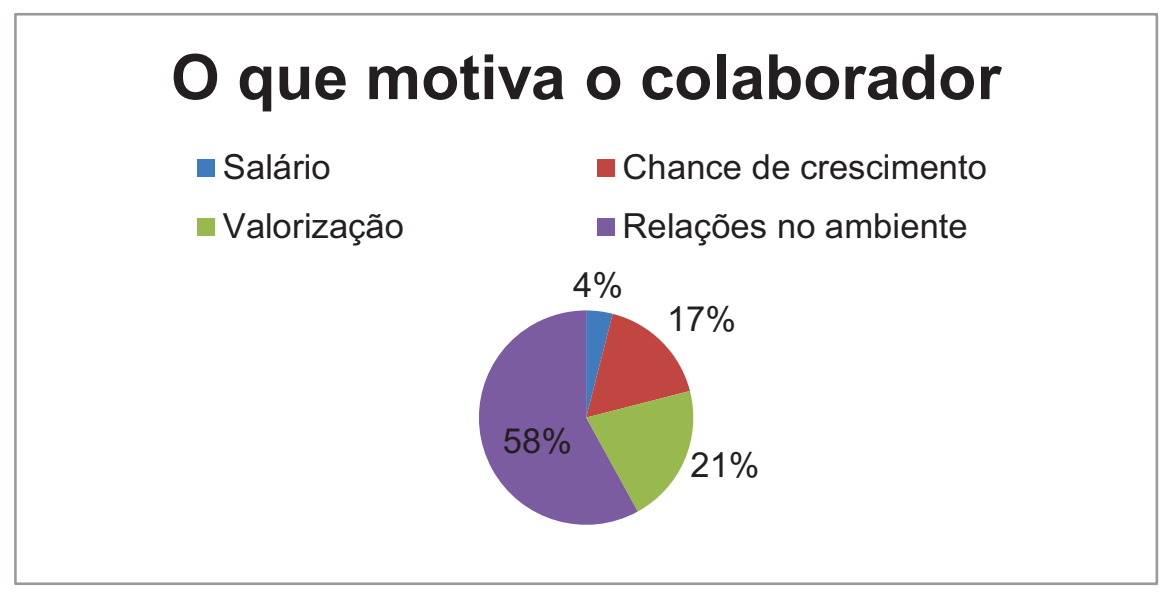

Fonte: os autores

O mercado de trabalho está alerta às mudanças e cada vez mais incentivando jovens com um futuro promissor. As organizações estão querendo esse futuro profissional em sua equipe, investindo em treinamentos e cursos. O profissional precisa ter certeza que oportunidades de crescimento irão surgir, motivando-o a cada dia mais estar integrado na empresa.

$\mathrm{Na}$ pergunta "a empresa oferece oportunidades de crescimento profissional"? 61\% responderam que sim. Uma das fontes de motivação é sabermos que teremos um crescimento na organização, pois os mesmos não pensarão duas vezes para mudar de empresa, onde outra lhe oferecerá um mínimo de oportunidade de conhecimento.

Gráfico 4 - A empresa oferece oportunidades de crescimento profissional?

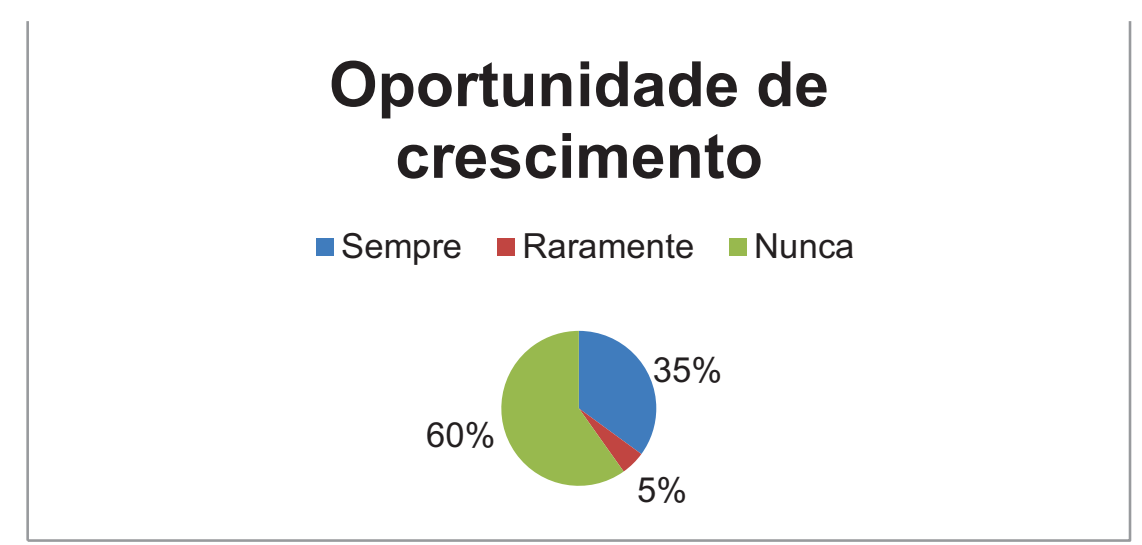

Fonte: os autores 
Conhecimento é algo que ninguém pode nos roubar. Quando somos motivados por aprendizado, tudo se torna um desafio. A sede de aprender, se auto desafiar, é uma fonte de motivação que persiste em se renovar a cada dia, assim, como podemos observar no gráfico abaixo é possível compreender que $76 \%$ dos entrevistados afirmam que o aprendizado é o que realmente os motiva.

Gráfico 5 - Trabalhar nesta empresa/organização é um (a)

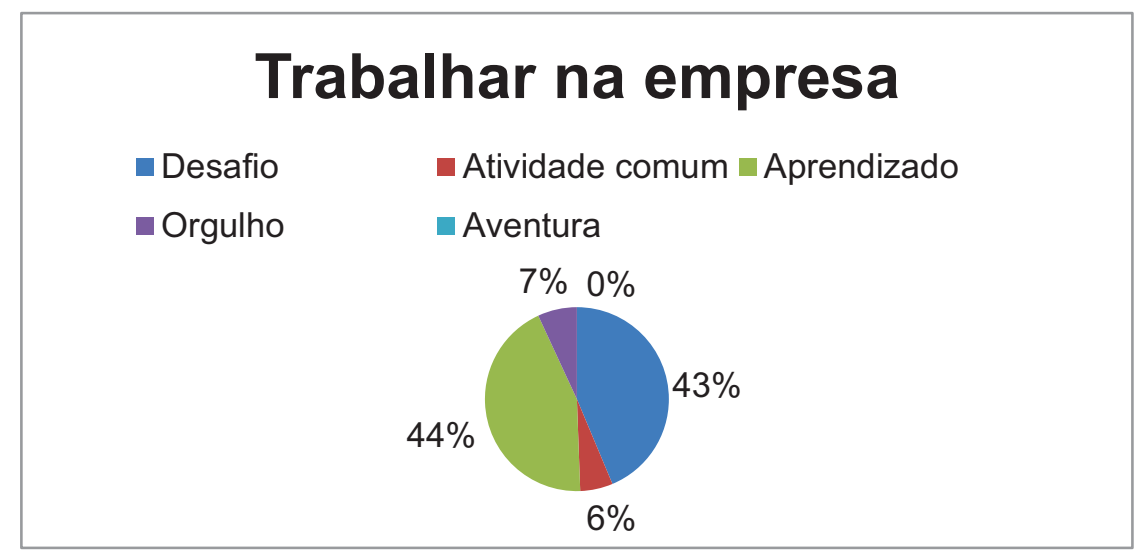

Fonte: os autores

Um dos fatores que incomodam os colaboradores é a falta de reconhecimento. No gráfico abaixo 68\% confirmam que na empresa pesquisada os colaboradores se sentem bastante reconhecidos pela empresa. Sentir-se útil e parte da empresa é o que todos querem, sendo valorizados por cada esforço, por cada objetivo alcançado. Agindo dessa forma o empregador demonstra aos seus colaboradores o quanto o capital humano é importante. A queda de produtividade é maior em ambientes organizacionais onde os empregados não se sentem valorizados. Quem produz em uma empresa onde não é reconhecido?

Gráfico 6 - Você se sente reconhecido pela empresa/organização?

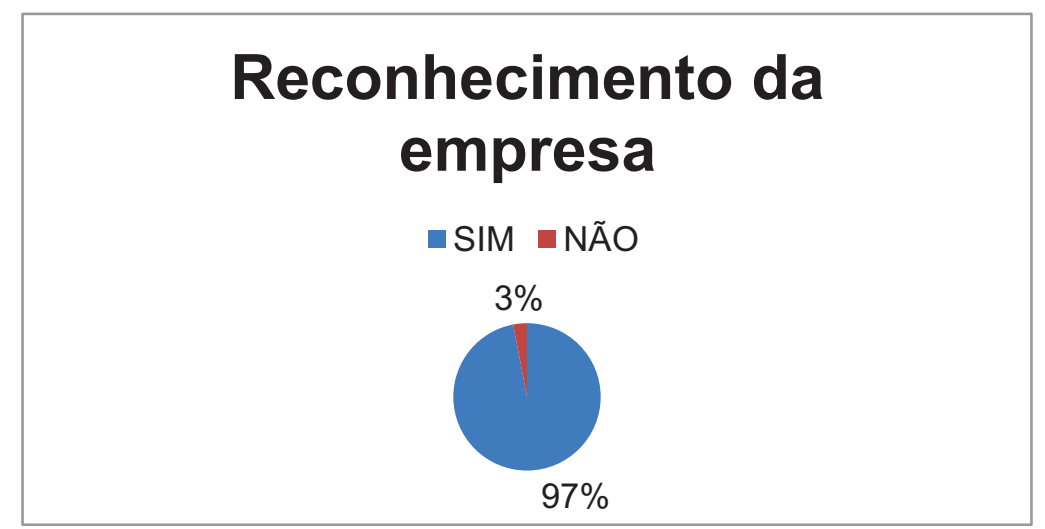

Fonte: os autores 
O gráfico abaixo demonstra que os colaboradores responderam que $91 \%$ se sentem bastante motivados. A motivação é algo interno, mas o ambiente externo ajuda, proporcionando fontes de motivação, um novo cargo, uma troca de serviços, um novo desafio, algo que satisfaça as necessidades e que rompe a barreira de equilíbrio interno.

Gráfico 7 - Qual o seu grau de motivação?

\section{Grau de motivação}

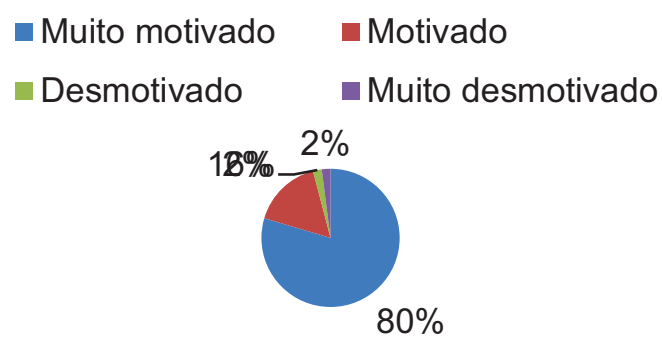

\section{Fonte: os autores}

A motivação diferencia de uma pessoa para outra. O que motiva e impulsiona todos os dias não são as mesmas coisas que movem o colega de trabalho. Por sermos indivíduos diferentes, os gostos e as preferências mudam de pessoa para pessoa. O resultado do gráfico abaixo corresponde à pergunta: "o que lhe motiva"? O resultado nos mostra que evoluir na carreira se encontra bem a frente de dinheiro. Isso só mostra que os profissionais estão cada dia mais pensando no futuro, sabendo que cada esforço ou objetivo alcançado será reconhecido.

Gráfico 8 - O que lhe motiva a trabalhar?

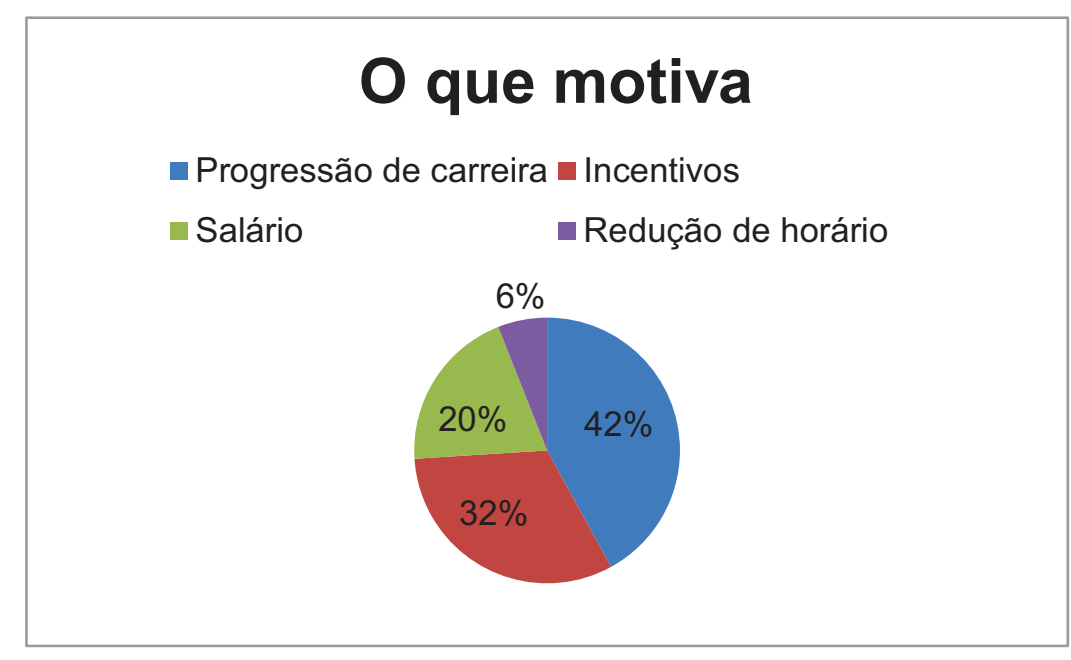

Fonte: os autores 
Toda empresa deve estar atenta aos seus colaboradores. O que fazem para produzir mais? Quais as expectativas que eles têm mediante a empresa? A instituição busca atender essas expectativas a cada dia? A empresa visa cada dia mais entender e buscar um clima organizacional produtivo?

Na pergunta "a empresa dá a devida atenção à motivação e à satisfação dos funcionários" 96\% afirmam que sim, a empresa mostra plena ciência de como anda a satisfação de seus colaboradores. Assim sendo, a mesma pode cobrar mais empenho. Esse questionário de desempenho deve ser um trabalho exclusivo do RH que, junto com os gestores, procuram solucionar essas questões de extrema importância à satisfação dos colaboradores.

Gráfico 9 - A empresa que você trabalha dá a devida atenção à motivação e satisfação dos seus funcionários?

\section{Atenção da empresa com a motivação e satisfação do colaborador}

$\because \mathrm{SIM} \backsim \mathrm{NÃO}$

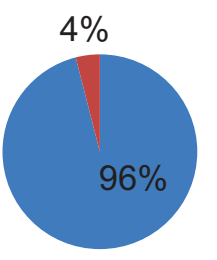

Fonte: os autores

Quando foi perguntado ao colaborador o grau de importância motivacional, em primeiro lugar, com a maior porcentagem, surgiu o plano de cargos e salários com 32\%. Existem algumas empresas que já reconhecem que esse fator é muito importante, pois muitos de seus colaboradores se sentem satisfeitos em saber que a empresa reconhece o seu profissional. $\mathrm{O}$ objetivo de se ter plano de cargos e salários na empresa é classificar o funcionário de acordo com suas habilidades, assim valorizando seus esforços de melhoria.

\section{CONSIDERAÇÕES FINAIS}

Na realização desse trabalho, por meio desta pesquisa, foi possível compreender que a motivação é um dos assuntos com múltiplas visões. 
Os colaboradores são motivados, acima de tudo, pela qualidade de seu trabalho e pelas relações que lhes dão suporte. Quanto mais motivado o ser humano estiver, maior será o conjunto de capacitações transformadas em ação prática. Qualquer instituição pode ter uma consistente e lucrativa ação na criação de motivos que levam pessoas a aumentar o padrão, a qualidade e a quantidade de suas ações.

Mediante o estudo realizado foi possível entender que a empresa mantém, na medida do possível, os padrões para atender as necessidades dos colaboradores, pois para estes os principais fatores motivacionais que predominam são o reconhecimento e o plano de cargos e salários.

Atualmente, é fundamental que as empresas busquem formar líderes e integrar pessoas com este perfil a seus quadros, o que demonstra a relevância do presente tema. Com base no que foi apresentado, é correto afirmar, então, que o líder motiva a equipe e deve estar preparado para estimular seus integrantes em relação ao trabalho, visando a torná-los mais efetivos em relação aos objetivos da empresa.

Percebemos que quando um colaborador está motivado em seu ambiente de trabalho, tudo flui melhor, tanto no trabalho que ele desempenha quanto para ajudar o colega na função. A empresa deve dar um pouco mais de atenção ao colaborador. Essa atenção surge não só da parte dos lideres, mas também dos colaboradores entre si.

\section{REFERÊNCIAS}

CHIAVENATO, I. Introdução à teoria geral da administração: uma visão abrangente da moderna administração das organizações. 7. ed. Rio de Janeiro: Campus, 2004.

CHIAVENATO, I. Introdução à teoria geral da administração. São Paulo: Elsevier, 2003.

DUTRA, Joel S. Gestão de pessoas: modelo, processos, tendências e perspectivas. 7 . reimp. São Paulo: Atlas, 2009.

FERREIRA, Paulo P. Administração de pessoas. 2. ed. São Paulo: Atlas, 2001.

LOPES, Michelle; OLIVEIRA, Waleska; QUEIROZ, André. Motivação e Liderança Dentro das Empresas. $2017 . \quad$ Disponível Em: https://revista.pgsskroton.com/index.php/rcger/article/view/3971 . Acesso em: 10 maio 2021.

MAXIMIANO, Antônio César Amaru. Introdução à Administração. 5. ed. São Paulo: Atlas, 2010.

RIBEIRO, Antonio L. Gestão de pessoas. São Paulo: Saraiva, 2006. 
SILVA, G. Motivação: uma análise do comportamento do indivíduo na organização. Administradores. Disponível em: http://www.administradores.com.br/artigos/tecnologia/motivacao-uma-analise-docomportamento-do-individuo-dentro-das-organizacoes/57558/. Acesso em: 12 dez. 2020.

SOUSA, K. Recompensas organizacionais. Psicologado Artigos. Disponível em: https://psicologado.com/atuacao/psicologia-organizacional/recompensas-organizacionais. Acesso em: 15 dez. 2020.

VROOM, Victor H. Gestão de pessoas, não de pessoal. Rio de Janeiro: Elsevier, 1997. 


\title{
INCLUSÃO SOCIAL: DESAFIOS DE PESSOAS TRANSGÊNERO NO AMBIENTE DE TRABALHO
}

https://dx.doi.org/10.48097/2674-8673.2022n6p08

\author{
Arandi Maciel Campelo ${ }^{1}$ \\ Erivaldo Silva Feliciano ${ }^{2}$ \\ Kathiane Moreira da Penha ${ }^{3}$
}

\section{RESUMO}

Pessoas transgênero e travestis estão presentes na população brasileira, assim como em outros países, e têm sua realidade hostilizada, silenciada e oprimida em vários âmbitos, inclusive no mercado de trabalho. O presente trabalho visa atribuir conhecimento aos gestores atuais e do futuro, trazendo uma contribuição social de inclusão e humanidade. Este artigo foi elaborado por meio de uma pesquisa bibliográfica, qualitativa, com materiais já formulados e debatidos por outros autores e pesquisadores, além da utilização de um questionário formulado na plataforma Google Forms. Foram recolhidas amostras de vivências das participantes vinculadas à instituição não governamental NATRAPE (Nova Associação de Travestis e Transexuais de Pernambuco) que trouxeram para o estudo a conclusão de que apesar dos crescentes debates em torno da diversidade, as oportunidades de inserção de pessoas transgênero no mercado de trabalho ainda são escassas, sendo necessárias ações de estímulo à inclusão e ao desenvolvimento de políticas públicas que favoreçam a comunidade LGBTQIA+.

Palavras-chave: Inclusão social. Gestão inclusiva. Pessoas transgênero. Ambiente de trabalho.

\section{Data de submissão: 22/09/2021 Data de aprovação: 09/11/2021}

\begin{abstract}
Transgender people and transvestites are present in the Brazilian population, as well as in other countries, and their reality is harassed, silenced and oppressed in various spheres, including the labor market. The present work aims at attributing knowledge to current and future managers, bringing a social contribution of inclusion and humanity. This article was prepared through a bibliographical, qualitative research, with materials already formulated

\footnotetext{
1 Orientador, Doutor em Educação-Universidade Federal de Pernambuco Administrador -Universidade de Pernambuco -FCAP/UPE Mestre em Planificación y Gestion Organizacional - Universidad Autonoma de Madrid / Espanha Mestre em Direccióny Organización de Hospitales y Servicios de Salud-Universidad Politécnica de Valencia / Espanha Especialista em Marketing-FCAP/UPE Consultor em Sistemas Organizacionais, desde 1984 Professor Universitário, desde 1986 Professor e Diretor Acadêmico da Faculdade Metropolitana da Grande Recife. E-mail: arandi@metropolitana.edu.br

${ }^{2}$ Estudante do curso de Administração da Faculdade Metropolitana da Grande Recife.

E-mail: erivaldo.sfeliciano@gmail.com

${ }^{3}$ Estudante do curso de Administração da Faculdade Metropolitana da Grande Recife.

E-mail: kathianemoreira123@gmail.com
} 
and discussed by other authors and researchers, in addition to the use of a questionnaire formulated on the Google Forms platform. Samples of the experiences of participants linked to the non-governmental institution NATRAPE (New Association of Transvestites and Transsexuals of Pernambuco) were collected, which brought to the study the conclusion that despite the growing debates around diversity, the opportunities for insertion of transgender people in the market jobs are still scarce, requiring actions to encourage inclusion and the development of public policies that favor the LGBTQIA+ community.

Keywords: Social inclusion. Inclusive management. Transgender people. Workplace.

\section{INTRODUÇÃO}

Pessoas LGBTQIA+ sofrem repressões sociais por não se encaixarem perfeitamente no padrão binário aceitável e imposto pela narrativa normativa para uma vaga de trabalho. A transfobia começa cedo e está relacionada a uma reação: a quebra dos padrões sociais de gênero. Essas pessoas comumente são excluídas de vários grupos sociais, seja pelos próprios pais, familiares ou pela sociedade, tendo constantemente sua orientação e/ou identidade questionada.

Basta uma rápida olhada nos anúncios de emprego para verificar que o mercado de trabalho possui uma estrutura segmentada pelo gênero, definido pela dicotomia convencional homem/mulher. Muitos valores subjetivos e avaliações estão embutidos nesta divisão sobre aquilo que um homem ou uma mulher pode ou deve fazer. Pessoas com uma ambiguidade de gênero poderiam causar confusão e sentir rejeição por não se encaixarem facilmente nos nichos que existem no mercado de trabalho. A mesma ambiguidade pode ser vista como algo capaz de perturbar o desempenho da função, principalmente num mundo onde muitas ocupações se exercem vinculadas à apresentação e conservação da imagem. (ADELMAN, 2003, p. 83-84).

A partir desse contexto, a elaboração deste artigo visa atribuir conhecimento e desmistificar a visão estigmatizada para com o público LGBTQIA+ por pessoas que estão à frente de empresas públicas e privadas, a fim de contribuir para a inserção deste grupo que, muitas vezes, é visto de maneira pejorativa ou desnecessária para contribuir com a rentabilidade e sustentação das empresas.

\section{REFERENCIAL TEÓRICO}

Quando se fala em empresas, trabalho, cargos, salários e gestão, logo se associa o capital humano, que traz à tona o recrutamento e seleção de pessoas. É impossível falarmos de pessoas se não falarmos sobre todas elas, de todos os grupos, sem distinção, mais 
especificamente sobre pessoas transexuais e travestis, adjetivos estes que são marcados por lutas, dores, preconceito e autoafirmação. No decorrer da História estas pessoas enfrentaram preconceitos, medos, dúvidas e até violência física e emocional. Entre cirurgias pioneiras e arriscadas e histórias de superação, transexuais lutaram no passado e continuam lutando pela liberdade de assumirem quem são de verdade. (NORONHA, 2018).

A discriminação para com pessoas transgênero é uma questão estrutural, fundada na formação cultural e educacional da sociedade, cujos valores de normalidade/anormalidade são formados por meio da construção de questões históricas. Baseados em filosofias religiosas, como a judaico-cristã, os valores culturais que regem as normas de gênero e sexualidade são definidos a partir de uma visão binária (macho/fêmea) e heteronormativa/reprodutiva (que considera o coito entre um homem e uma mulher com o objetivo de procriação o único modelo adequado). Assim, por terem imagens em desacordo aos padrões normativos impostos, travestis e mulheres transexuais são frequentemente marginalizadas e seus direitos são negados devido à sua identidade de gênero. (FIGUEIREDO, 2008).

Nas últimas décadas, discussões acerca das barreiras enfrentadas pelo grupo LGBTQIA+ para terem acesso a direitos jurídicos e proteção contra discriminação vêm sendo realizadas (PEREIRA, 2016) e as políticas de combate ao preconceito no ambiente de trabalho esbarram em questões culturais que permeiam a discriminação e a não aceitação da diversidade. (BUTLER, 2003).

Oliveira e Costa (2007) expõem a opressão sofrida por homossexuais, no sentido de serem "obrigados" a aderir à heterossexualidade, sendo punidos ou considerados doentes ao se oporem a tal situação. Nesse sentido, é importante compreender o empoderamento que movimentos em prol da diversidade têm causado, por meio de políticas públicas, ainda que fragilizadas, na forma como a sociedade e o poder público lidam com a garantia de direitos sexuais e de cidadania para as pessoas LGBTQIA+.

\section{ORIGEM DO ESTIGMA DO RACISMO E DO PRECONCEITO NA SOCIEDADE}

O racismo é uma teoria que defende a superioridade de determinadas etnias em relação as outras, sugerindo ou não a segregação racial ou a extinção de determinados grupos. No Brasil é possível verificar formas plurais de racismo, preconceito e discriminação, que se expressam nos índices de escolaridade, acesso ao mercado de trabalho e natalidade de determinados grupos. Esses dados revelam também que o Brasil é o país que mais mata pessoas transexuais e travestis. (BORTONI, 2017). O preconceito, principal motivação para o 
crime de ódio, se faz presente pelo fato de que os criminosos não aceitam as diferenças, sejam elas de etnia, religião, gênero, orientação sexual ou identidade sexual.

As políticas públicas tem papel fundamental na manutenção e/ou superação das opressões de gênero e sexuais. Porém, se não estiverem direcionadas às demandas específicas do público alvo, podem reforçar preconceitos e desigualdade. Por outro lado, se essas demandas recebem a devida atenção e são direcionadas da forma correta, com a implementação de ações e programas, garantem os direitos necessários aos seus beneficiários, assumindo um perfil universalista, mas generificado e sexualizado, a exemplo de programas de combate à homofobia nas áreas de educação, saúde e segurança. (MELLO et al., 2012).

\section{Transgênero e mercado de trabalho}

Apesar de muito estar se falando na atualidade dos direitos das pessoas LGBTQIA+, sabe-se que muito ainda precisa ser elaborado, discutido e compreendido em relação à quebra de tabus que a sociedade impõe ao que é considerado normal e aceito quanto à imagem pessoal do indivíduo. Os padrões exigidos por essa sociedade dão origem a práticas de discriminação que nem mesmo são reconhecidas como tais, pois, segundo essas ideias, o correto é ter o perfil deste padrão.

Aqui são abordadas as perspectivas e as vivências de pessoas trans de Pernambuco em relação às oportunidades no mercado de trabalho. Por que abordar apenas a causa das pessoas trans e não da totalidade do grupo LGBTQIA+? As pessoas transgênero subjetivamente se identificam com o gênero oposto ao que lhe foi atribuído fisicamente no nascimento, ou seja, o corpo da pessoa não corresponde à sua própria subjetividade, gerando um conflito desde a sua infância, ao perceber seus órgãos genitais, corte de cabelo e vestimentas, entre outras coisas. Na adolescência é quando os hormônios da puberdade começam a atuar. Logo, as características secundárias corporais ficam mais evidentes, como o aparecimento da barba e seios, o que faz com que o desejo de mudança seja ainda mais aflorado, pelo fato do corpo não corresponder ao gênero psicológico e com a percepção que o indivíduo tem em relação ao mundo e a suas particularidades. Butler (2003) evidencia que o gênero é, de fato, aquele que a pessoa sente que pertence, independentemente do que a construção social impõe. Segundo a autora:

se o caráter imutável do sexo é contestável, talvez o próprio construto chamado "sexo" seja tão culturalmente construído quanto o gênero; a rigor, talvez o sexo sempre tenha sido o gênero, de tal forma que a distinção entre sexo e gênero revelasse absolutamente nenhuma. Se o sexo é, ele próprio, uma categoria tomada em seu gênero, não faz sentido definir o gênero como uma interpretação cultural do sexo. O gênero não deve ser meramente 
concebido como a inscrição cultural de significado num sexo previamente dado. (BUTLER, 2003, p. 28).

De modo geral, as pessoas só são felizes quando se realizam e é impossível encontrar alguém realmente realizado se essa pessoa não faz aquilo que ela quer ou quando realmente assume as coisas que ela gosta. Uma pessoa que não faz o que deseja, com mínimo de prazer, dificilmente conseguirá viver uma vida autêntica, se tornando frustrada. Pessoas que não se realizam consigo mesmas se tornam amargas, tristes, solitárias e depressivas, o que pode vir a ocasionar suicídios.

Houve gerações em que as pessoas sofriam muito mais, as mulheres principalmente, que aceitavam qualquer situação para manter uma postura social ou para zelar pela honra de seu nome e de sua família. Muitas vezes sofriam abuso físico e psicológico ou estavam fadadas a viver uma relação conjugal infeliz, mediante a cultura machista e misógina que ainda existe. Porém, graças às origens dos movimentos sociais que iniciaram uma luta por visibilidade para questões da desigualdade de gênero, essa pauta ganhou visibilidade, dando origem às políticas de proteção à mulher, trazendo à tona as situações de abuso e estimulando as denúncias, e isso é uma evolução que segue diariamente, apesar da constante luta por direitos.

O papel da família é primordial para o processo da caminhada na vivência diferente do que se espera socialmente. É muito conflitante não se identificar consigo próprio ou não se identificar com a expectativa do que é considerado aceito, o que gera sofrimento quando o indivíduo não é acolhido no espaço familiar ou quando aqueles que são próximos tentam alterar a identidade de gênero por meio de coerção. Para a maioria das pessoas, isso amplia o conflito e o sofrimento que ela própria vivencia.

Durkhein (1996) traz que a ciência, em princípio, nega a religião, mas compreende que a religião existe. Sendo assim, não pode ser negada. Para este autor, toda religião tem como objetivo separar o mundo em profano e sagrado. A sociedade brasileira tem fortemente em sua cultura que a aceitação das relações afetivas deve ser heterossexual. O que, de certa forma, define papéis para homens e mulheres, por serem agentes de reprodução da vida. (MOITA, 2006).

A sociedade precisa entender que pessoas trans não são más, não são pessoas que estão sujeitas a uma vida promíscua ou que o fato de ser trans está ligado a algo diabólico ou religioso. A transexualidade, na verdade, é uma condição que é atribuída no nascimento. Homens e mulheres cisgênero (pessoas que se identificam com seu gênero de nascimento) vivenciam os plenos direitos de sua sexualidade, enquanto homens e mulheres transgênero 
precisam, a todo momento, afirmar e explicar sua própria existência. Para reduzir e combater as violências e preconceitos de gênero é preciso identificar e discutir os sistemas de ordem impositiva e binária.

Butler (2003) mostra que o conceito de gênero não se resume ao fator biológico, que designa o sujeito como um homem ou uma mulher, mas leva em conta a identidade psicológica, ou seja, a pessoa é o que ela acredita ser, e que é isso o que importa. É importante estar atento que a orientação de gênero e a orientação sexual são diferentes, ou seja, um homem cis pode ser gay ou uma mulher cis pode ser lésbica o que os faz "homens e mulheres homossexuais". Pessoas transgênero sofrem maior repressão quanto aos paradigmas do que é ser homem ou mulher, das definições que a sociedade conservadora dita no decorrer da existência em sociedade. E é em relação a isso que pessoas trans têm muita dificuldade na aceitação, tanto no âmbito familiar quanto social, e também no mercado de trabalho.

É importante no século XXI, e na visão pós-moderna que estamos vivenciando, que as pessoas que estão à frente de empresas, como líderes e gestores, trabalhem a desmistificação em relação a pessoas trans. Sabe-se que todo grupo LGBTQIA+ tem dificuldades de inclusão social, mas é muito mais comum que pessoas gays com aparência normativa consigam se estabelecer em meio ao mercado de trabalho do que uma mulher transgênero que tem características físicas e traços masculinos, ou de homem transgênero que tem algumas características femininas tenha a mesma chance de colocação no mercado de trabalho. A questão de aceitação é muito mais difícil se tratando de pessoas que transcendem o gênero porque isso causa uma desconstrução do que nossa sociedade heteronormativa criou.

Pelúcio (2005) evidencia que pessoas trans e travestis, em geral, têm dificuldade de acesso à escolaridade, o que perpetua estarem em posições sociais mais baixas, contribuindo para a falta de qualificação do seu processo profissional e agravando o paradigma negativo em torno de sua identidade de gênero. Deste modo, é evidente que existe uma grande necessidade de implementação de políticas nas empresas que contribuam com a inclusão de pessoas trans e travestis nas organizações. É muito importante que os gestores tenham a consciência de que esses indivíduos são pessoas como quaisquer outras, que pensam, que sentem, que desejam, que sonham e que merecem respeito e consideração.

Benevides \& Simpson (2018), da Associação Nacional de Travestis e Transexuais (ANTRA), dizem que a transfobia faz com que cerca de $90 \%$ desse grupo recorra à prostituição, ao menos em algum momento da vida. Além disso, pessoas trans e travestis têm sua expectativa de vida reduzida a 35 anos, simplesmente por serem quem são. Dados da ANTRA (2018) revelam que 175 mulheres trans foram assassinadas. Isso representa 41\% a 
mais em relação ao ano anterior, só no Brasil. É devido a todas as dificuldades que essas pessoas passam desde a infância que é preciso repensar e rever alguns conceitos socioculturais. Travestis e transexuais existem, precisam de notoriedade e respeito, bem como oportunidades de crescimento pessoal e profissional, para que a garantia dos direitos básicos do ser humano seja plena.

\section{METODOLOGIA}

O método escolhido para o desenvolvimento deste trabalho de conclusão de curso é a pesquisa qualitativa, bibliográfica e de campo. Nesse trabalho foi estudada a inclusão social de pessoas do grupo LGBTQIA+, especificando a quarta letra da sigla que corresponde a transgênero, transexuais e travestis, que caracterizam o objeto de estudo.

Foi realizada pesquisa bibliográfica de livros e artigos científicos na base de dados do Google Acadêmico, bem como coleta de dados online na Associação Nacional de Travestis e Transexuais (ANTRA), entidade voltada ao público-alvo deste estudo. Os materiais bibliográficos compreendem o período entre os anos de 2003 e 2021, além de literatura clássica dos anos 1990.

A pesquisa de campo foi realizada através de um questionário formulado na plataforma Google Forms e enviado para integrantes da Nova Associação de Travestis e Transexuais de Pernambuco - NATRAPE, juntamente com o Termo de Consentimento Livre e Esclarecido para o público alvo. O sigilo e a preservação dos dados pessoais dos participantes foram garantidos, sendo usados nomes fictícios para relatar algumas experiências vividas. Os dados foram recolhidos entre os meses de maio e junho de 2021.

\section{DESENVOLVIMENTO DA PESQUISA DE CAMPO}

No resultado de amostragem referente à pesquisa elaborada e divulgada para o público alvo, percebe-se que as informações dos entrevistados correspondem às questões abordadas no tema, reafirmando que nossa sociedade ainda precisa evoluir nas questões referentes a gênero e sexualidade, relembrando que a constituição nos diz que todos são iguais perante a lei, sem distinção de qualquer natureza, garantindo aos brasileiros e aos estrangeiros residentes no país a inviolabilidade do direito à vida, à liberdade, à igualdade, à segurança e à propriedade. (BRASIL, 1988).

No primeiro gráfico exposto com a coleta de amostragem percebemos que dentre as 16 pessoas que aceitaram fazer parte da pesquisa $75 \%$ têm idade entre 18 e 30 anos, 
correspondendo a parte azul do gráfico, e 18,8\% de nossos entrevistados (as) têm idade entre 40 e 50 anos. $7 \%$ do total correspondem aos que têm mais de 50 anos de idade.

Qual é a sua faixa etária?

16 respostas

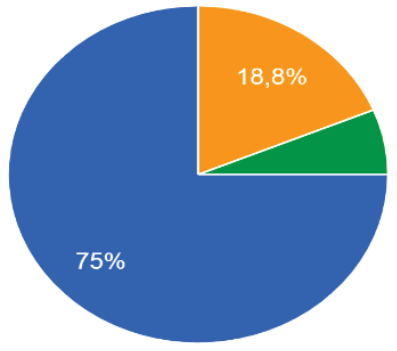

B) 18 a 30 anos

C) 30 a 40 anos

D) 40 a 50 anos

E) Acima de 50 anos

No segundo gráfico, referindo-se às múltiplas variações e formas que podem se afirmar sobre o gênero com qual as pessoas se identificam e pertencem, $81 \%$ de nossas entrevistadas são mulheres trans, $12,5 \%$ são pessoas não-binárie e $6,2 \%$ se entendem como travestis.

Butler (2003) traz a informação de que concepção heteronormativa e binária estruturada como modelo cultural hegemônico - cria dificuldades para que os indivíduos exerçam a própria identidade. Não-binárie são aquelas pessoas que, mesmo não sendo travestis ou transexuais, fogem do conceito de "normalidade" binaria.

Qual é o seu gênero?

16 respostas

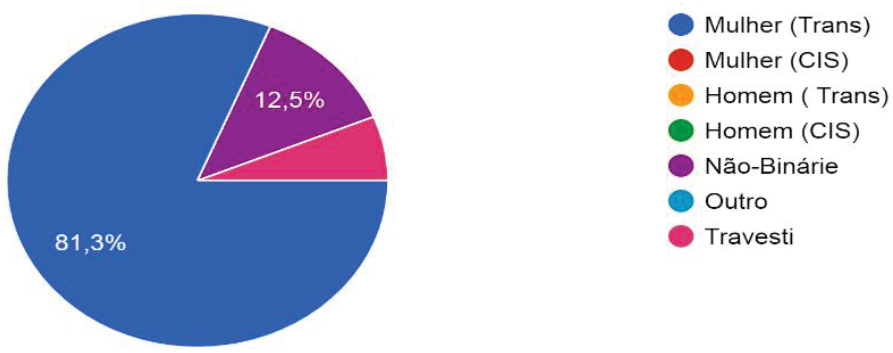

Muitas pessoas confundem sexualidade e gênero. A sexualidade está atrelada às distinções anatômicas exemplo (homem x mulher, mulher x mulher, e homem x homem) a sexualidade é vinculada ao sentido afetivo sexual, ou seja, por quem você sente atração afetiva ou vontade de ter um relacionamento conjugal e etc. Gênero é o termo utilizado para designar a construção social de cada pessoa, quem de fato ela é e como ela se expressa perante a sociedade, ou seja, um homem cis ou trans, pode ser gay ou hetero assim como $62,5 \%$ de nossos (as) entrevistados (as) se identificam como heterossexuais. $18,8 \%$ se identificam como homossexuais. Não se pode esquecer das pessoas que se identificam como pansexual (pessoas que se sentem atraídas por todos os gêneros), bissexual (pessoa que se sente atraída por homens e mulheres), e assexual (pessoa que não sente atração sexual por 
qualquer gênero ou apenas se relaciona afetivamente), que obtiveram o percentual total de $18,7 \%$. Nenhuma dessas pessoas correspondentes a estas sexualidades estiveram presentes na pesquisa.

Com qual orientação sexual você se identifica?

16 respostas

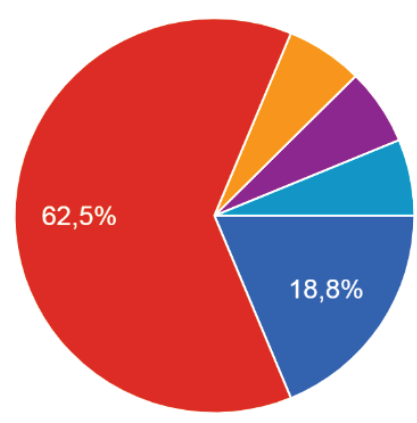

Homossexual (Se relaciona com indivíduo do mesmo sexo)

Héterossexual (Se relaciona com indivíduo do sexo oposto)

Bissexual (Se relaciona com os Gêneros Binários, homens ou mulheres)

Pansexual (Se relaciona com todos os gêneros sexuais)

Assexual (Pessoa que não sente atra...

Outro

É comum que pessoas trans, assim como qualquer outra pessoa queer, perceba na sua infância suas características, o modo como se comporta ou como as pessoas o reprimem, e evidenciam que de certa forma não seguimos os padrões heteronormativos. Os dados apontam que $56,3 \%$ de nossos(as) entrevistados(as) identificaram na sua infância suas definições do eu social, 31,3\% obtiveram essa percepção na adolescência e $12,5 \%$ na fase adulta.

Em qual fase de sua vida você se percebeu como uma pessoa Transgênero?

16 respostas
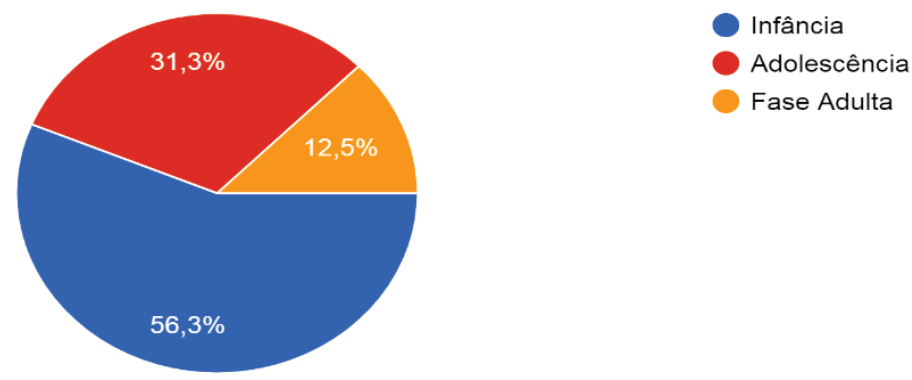

Os planos para a vida profissional de nossos (as) participantes têm maior intensidade no empreendedorismo pessoal. 50\% responderam que têm por objetivo ter seu próprio negócio, facilitando suas vivências e investindo em algo que é seu. Pelúcio (2005) evidencia que pessoas trans em geral têm certa dificuldade de acesso a escolaridade, contribuindo para a falta de qualificação e agravando estigmas negativos em relação a sua identidade. 31,3\% revelaram ter curso superior e desejam ingressar em uma empresa para fazer a sua carreira. $12,5 \%$ relatam que não pensaram sobre isso. $6,2 \%$ não se pronunciaram sobre o assunto. 
Quais são seus planos em relação à sua carreira profissional ? 16 respostas

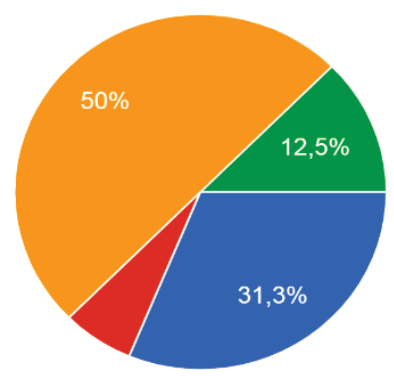

Sou formado(a) em curso superior e tenho o objetivo de fazer carreira em grandes empresas.

Sou concurseiro(a) e minha meta é passar em um concurso público.

Pretendo ter meu próprio negócio.

Ainda não pensei sobre isso.

Quanto ao grau de escolaridade de nossos (as) entrevistados (as) 56,3\% possuem ensino médio completo. $25 \%$ têm curso superior incompleto, estão cursando ou abandonaram, e apenas $12,5 \%$ têm curso de graduação concluído, restando 9,8\% que não especificaram.

Qual é a sua escolaridade?

16 respostas

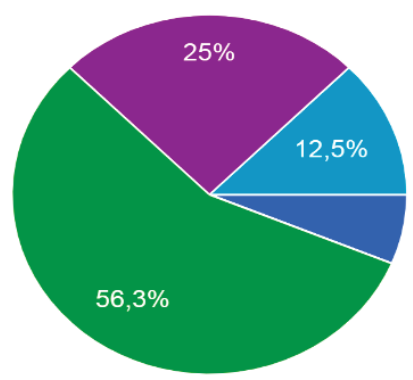

Tenho ensino fundamental incompleto

Tenho ensino fundamental completo.

Tenho ensino médio incompleto.

Tenho ensino médio completo.

Tenho superior incompleto.

Tenho graduação completa.

Tenho pós graduação.

Tenho mestrado.

$1 / 2$

O gráfico a seguir mostra que $81,3 \%$ de nossos (as) participantes sentiam-se preparados (as) para o mercado de trabalho, enquanto 18,8\% responderam de forma negativa.

Você se sente preparado (a) para o mercado de trabalho? 16 respostas

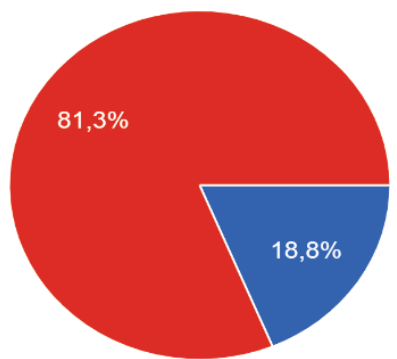

Não, não me sinto preparado (a)

Sim, me sinto preparado (a).

Ao ser perguntado aos participantes se eles (as) achavam que as questões referentes à temática de inclusão de pessoas LGBT estavam sendo suficientes para inclusão dos mesmos no mercado de trabalho $93,8 \%$ relataram que muito ainda precisa ser feito e $6,2 \%$ não deram sua opinião. 
Qual sua visão em relação ao nome social?

16 respostas

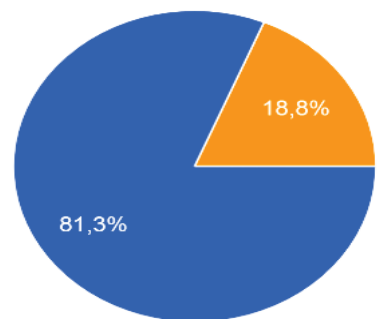

Para mim, o nome social representa minha essência e eu não abro mão dele.

Não acho que o nome social seja uma prioridade.

Para mim, é indiferente se me tratam pelo nome social ou não

Ainda sobre o nome social e/ou civil 43,8\% relatam que algumas pessoas the tratam pelo seu nome social, outras não. 37,5\% informam que são tratados (as) por seu nome social. $18,3 \%$ não se pronunciaram sobre esta questão.

Você é tratado(a) pelo seu nome social?

16 respostas
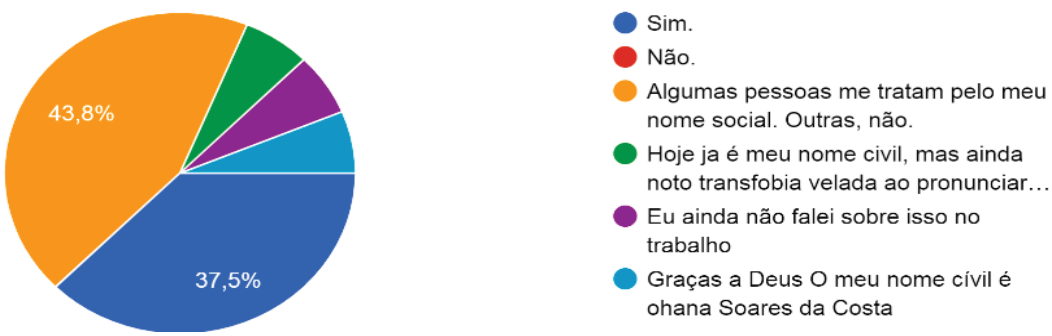

Ao serem questionados (as) se tinham algum tipo de receio de se qualificar por conta de sua orientação de gênero, 56,3\% revelaram que sim enquanto 43,8\% disseram não ter receio. Isso reforça a afirmação de Butler (2003) de que concepção heteronormativa e binária estruturada como modelo cultural hegemônico - cria dificuldades para que os indivíduos exerçam a própria identidade, dificultando sua inserção como pessoa sociável que tem direito a estudar, trabalhar e viver como qualquer cidadão comum.

Você já teve receio de se qualificar por causa da sua orientação de gênero?

16 respostas
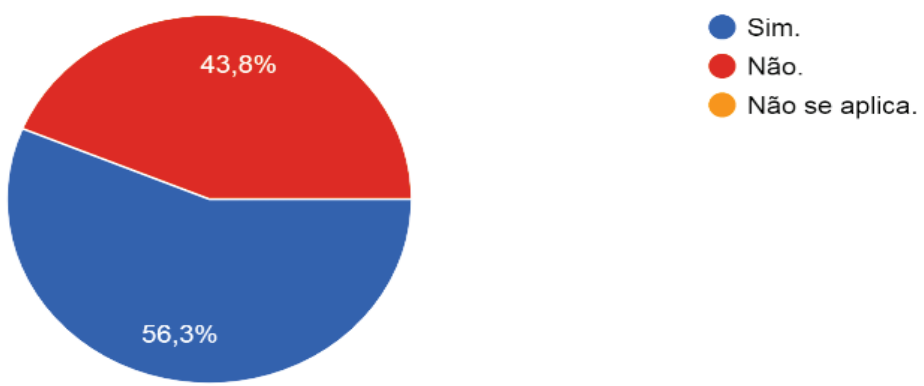

Sabe-se que por conta do preconceito enfrentado pela população trans muitas (os), infelizmente, não têm acolhimento familiar e às vezes são postas para fora, tendo que viver contando com a sorte ou com uma mão amiga que lhe dê suporte. Em relação a essas 
vivências foi questionado se os (as) participantes já viveram em situação de vulnerabilidade ou de rua. 56,3\% disseram que não, mas conhecem pessoas nessa situação. 31,3\% revelaram que já vivenciaram essa experiência e apenas 12,5\% tiveram a sorte de não passar por isso.

Você já viveu situação de vulnerabilidade ou situação de rua?

16 respostas

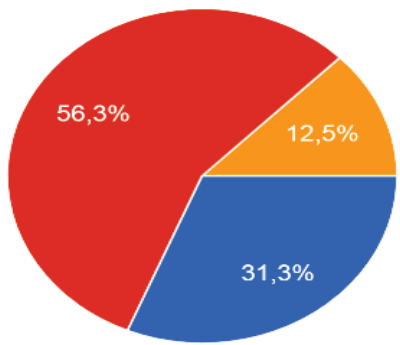

Infelizmente, sim

Não, mas conheço pessoas que sim

Não, nunca.

Sim, ainda vivo

É devido a uma grande parte da sociedade ser intolerante e ignorante que muitas melhorias no campo de vida pessoal e profissional de pessoas trans e travestis não têm avanço significativo, mesmo este tema sendo um pouco mais recorrente nos últimos anos. Segundo a Associação Nacional de Travestis e Transexuais (ANTRA), a transfobia faz com que cerca de $90 \%$ desse grupo recorra à prostituição, ao menos em algum momento da vida. Em decorrência deste fato foi perguntado aos participantes se já tiveram que recorrer a essa alternativa para sobrevivência. 37,5\% disseram que não, mas têm algum (a) amigo (a) que sim. 31,1\% relataram que não, e 31,3\% afirmam que sim e que ainda vivem da profissão.

Alguma vez, você já atuou como Profissional do Sexo para sobreviver? 16 respostas

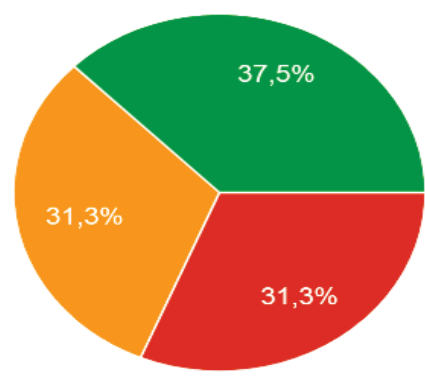

Sim. Hoje, não mais

Sim. E continuo nessa profissão.

- Não, nunca.

Não, mas tenho colegas que sim

Foi perguntado se nossos (as) participantes achavam importante que os gestores e pessoas à frente de empresas tivessem mais conhecimento sobre a causa, além de uma mente livre de preconceitos e diversificada. 93,8\% disseram que é importante haver pessoas livres de preconceitos à frente de cargos de gestão e $6,2 \%$ não se pronunciaram. 


\section{CONSIDERAÇÕES FINAIS}

Mediante as situações abordadas neste presente estudo, junto aos dados recolhidos na pesquisa de campo, conclui-se que a visibilidade de pessoas trans e travestis ainda se encontra em um patamar de desigualdade, vulnerabilidade e descaso. Nessa realidade é preciso ter apoio de forças políticas, além de haver uma necessidade de diálogo com os movimentos sociais, buscando amplificar a humanização desses corpos, perante uma visão do estigma social. É preciso garantir a essas pessoas um emprego e trabalhar para um futuro com menos desigualdades e mais oportunidades, pois assim como qualquer pessoa que trabalha e se esforça, as pessoas trans também têm este direito. Todos devem fazer sua parte e amar o s eu próximo como a si mesmo. É dever de toda a sociedade estimular o melhor das pessoas para que diminua a intolerância e a distinção social. Que todos possam ser também gestores do futuro, abandonando práticas discriminatórias que só dificultam a vida de nossos irmãos e semelhantes.

\section{REFERÊNCIAS}

ADELMAN, Miriam. Travestis e Transexuais e os Outros: Identidade e Experiências de Vida. Niterói: UFF, 2003.

BRASIL. Constituição Federal de 1988. (Texto compilado até a Emenda Constitucional 95 de 15/12/2016). Disponível em: https://www.senado.leg.br/atividade/const/con1988/con1988_15.12.2016/art_5_.asp. Acesso em: 05 jun. 2021.

BUTLER, Judith. Problemas de gênero: feminismo e subversão da identidade. Rio de Janeiro: Civilização Brasileira, 2003.

BENEVIDES, Bruna; SIMPSON, Keila. Mapa dos assassinatos de travestis e transexuais no Brasil em 2017. Associação Nacional de Travestis e Transexuais, 2018.

BORTONI, Larissa. Expectativa de vida de transexuais é de $\mathbf{3 5}$ anos, metade da média nacional. Jun. 2017 disponível em: https://www12.senado.leg.br/noticias/especiais/especialcidadania.Acesso em: 05 jun. 2021.

DURKEIN, Émile. As formas elementares da vida religiosa. Rio de Janeiro: Martins Fontes, 1996.

FIGUEIREDO, A. R. Se pudesse ressurgir eu viria como o vento. Das narrativas da dor: um estudo sobre corporalidade e emoções na experiência da travestilidade. 2008. 248f. Dissertação (Programa de Pós-Graduação em Antropologia), Universidade Federal de Pernambuco, Recife, 2008. 
MELlO, Luiz; AVELAR, Rezende Bruno de; MAROJA, Daniela. Por onde andam as políticas públicas para a população LGBT no Brasil. Revista Sociedade e Estado, Brasília, v. 27, n. 2, p. 289-312, 2012c.

MOITA, Gabriela. A patologização da diversidade sexual: homofobia no discurso de clínicos. Revista Crítica de Ciências Sociais [Periódico de internet]. 2006 dez Disponível em: https://docplayer.com.br/35678645-A-patologizacao-da-diversidade-sexualhomofobia-nodiscurso-de-clinicos.html. Acesso em: 29 mar. 2021.

OLIVERIA, Luiz Fernando de; COSTA, Ricardo Cesar Rocha da. Sociologia para jovens do século XXI. Rio de Janeiro: Imperial Novo Milênio, 2007.

NORONHA, Heloisa. Colaboração para Universa. 2018. Disponível em: https:/www.uol.com.br/universa/noticias/redacao/2018/07/31/conheca-pessoas-trans-quemarcaram-a-historia-no-brasil-e-no-mundo.htm?cmpid=copiaecola. Acesso em: 28 maio 2021.

PELÚCIO, Larissa Maués. Nem todos os gatos são pardos. Cadernos Pagu, n.25, p. 217/248, jul. dez., 2005.

PEREIRA, C. F. Notas sobre a trajetória das políticas públicas de direitos humanos LGBT no Brasil. RIDH. Jan, 2016 disponível em: https://www3.faac.unesp.br/ridh/index.php/ridh/article/view/307.\%20Acesso\%20em\%20ago. \%20\%e2\%80\%93\%20set.\%202019. Acesso em: 29 maio 2021.

SODRÉ, Lu. Assassinatos de pessoas trans aumentaram 41\% em 2020. Brasil de Fato | São Paulo (SP) | 29 de Janeiro de 2021 Disponível em: https://www.brasildefato.com.br/2021/01/29/assassinatos-de-pessoas-trans-aumentaram-41em-2020. Acesso em: 29 mar. 2021.

SILVA, Gabriele. Qual o significado da sigla LGBTQIA+? 06 de out. de 2020. Disponível em: https://www.educamaisbrasil.com.br/educacao/dicas/qual-o-significado-da-siglalgbtqia. Acesso em: 05 jun. 2021.

Viva bem Uol. Aumento do número de suicídios entre a população trans preocupa ativistas. $2020 . \quad$ Disponível em: https://www.uol.com.br/vivabem/noticias/redacao/2020/09/09/aumento-do-numero-desuicidios-entre-populacao-trans-preocupa-ativistas.htm. Acesso em: 11 abr. 2021.

\section{Apêndice A - Modelo de questionário aplicado na pesquisa de campo}

1 - Qual é o seu nome? (Opcional)

2 - Qual é a sua faixa etária?

3 - Qual é o seu gênero?

4 - Em que cidade você vive?

5 - Com qual orientação sexual você se identifica?

6 - Em qual fase de sua vida você se percebeu como uma pessoa transgênero? 
7 - Você foi aceito (a) pelo seu núcleo familiar após informar sobre a sua con dição de gênero?

8 - Quais são seus planos em relação à sua carreira profissional?

9 - Qual é a sua escolaridade?

10 - Você se sente preparado (a) para o mercado de trabalho?

11 - Ainda que pouco, as questões de gênero estão começando a ser debatidas na sociedade. Você acha que isso já é o suficiente para a inclusão de pessoas LGBTQIA+ no mercado de trabalho?

12 - Você já passou por algum constrangimento em relação a sua condição de gênero em uma seleção de trabalho?

13 - Você é tratado (a) pelo seu nome so cial?

14 - Qual sua visão em relação ao nome social?

15 - Conte-nos sobre uma experiência vivida por você ou por alguém próximo que não foi selecionado em uma entrevista de emprego por ser LGBTQIA+. (Opcional)

16 - Você já teve receio de se qualificar por causa da sua orientação de gênero?

17 - Você já passou por algum constrangimento em relação ao uso do banheiro adequado para sua orientação de gênero?

18 - Você já abriu mão de um emprego por causa de preconceito por parte de outros (as) funcionários (as)?

19 - Para você é importante que gestores de empresas tenham uma mentalidade diversificada e livre de preconceitos?

20 - Você já viveu situação de vulnerabilidade ou situação de rua?

21 - Alguma vez você já atuou como profissional do sexo para sobreviver?

22 - Chegamos ao fim do formulário. Peço que você dê uma nota de 1 a 10 onde 1 significa "insatisfeito (a)" e 10 "muito satisfeito (a)". 


\title{
INOVAÇÃO DE PROCESSO EM UM CALL CENTER: DESAFIOS DE COLABORADORES EM UMA EMPRESA DE TV A CABO
}

\author{
https://dx.doi.org/10.48097/2674-8673.2022n6p09
}

\author{
Arandi Maciel Campelo ${ }^{1}$ \\ Everton Santana de Andrade ${ }^{2}$ \\ Lígia Amâncio da Silva ${ }^{3}$
}

\section{RESUMO}

Este artigo aborda conceitos sobre inovação, capacitação e motivação que gera a produtividade em uma empresa, retratando as dificuldades que os colaboradores enfrentam para conseguir se sobressair dos problemas, assim como as expectativas das organizações, mostrando a inovação de processo em um call center sobre as perspectivas dos colaboradores e os desafios que os mesmos enfrentam no dia a dia da empresa Cli-K. O estudo teve como objetivo identificar os principais pontos a serem melhorados quanto à inovação de processos no setor de serviços e na capacitação dos colaboradores, ressaltando o fator motivacional para conseguir alcançar a produtividade. O levantamento e análise foram realizados por meio da pesquisa de campo, através de um questionário fechado, aplicado entre 21 a 27/04/2021. Das 71 pessoas envolvidas, 55 (77\%) participaram do questionário. No contexto teórico, teve-se como base principal Chiavenato (2010). O estudo revelou o quão significante é a visão que os colaboradores possuem, pois atuam diretamente com os clientes na linha de frente enfrentando desafios, por isso é fundamental que as empresas invistam cada vez mais na inovação dos processos, na capacitação dos funcionários, dando importância ao fator motivacional para garantir a produtividade e bem estar de seus colaboradores.

Palavras-chave: Inovação de processo. Call Center. Desafios de colaboradores.

Data de submissão: $27 / 08 / 2021$

Data de aprovação: 20/10/2021

\begin{abstract}
This article addresses concepts about innovation, training and motivation that generate productivity in a company, portraying the difficulties that employees face to be able to stand out from the problems, as well as the expectations of organizations, showing process

\footnotetext{
${ }^{1}$ Orientador: Doutor em Educação - Universidade Federal de Pernambuco; Administrador - Universidade de Pernambuco - FCAP/UPE; Mestre em Planificación y Gestion Organizacional - Universidad Autonoma de Madrid / Espanha; Mestre em Dirección y Organización de Hospitales y Servicios de Salud - Universidad Politécnica de Valencia / Espanha; Especialista em Marketing - FCAP/UPE; Consultor em Sistemas Organizacionais, desde 1984; Professor e Diretor Acadêmico da Faculdade Metropolitana da Grande Recife. E-mail: arandi.campelo@globo.com ${ }^{2}$ Estudante do curso de Administração, da Faculdade Metropolitana da Grande Recife. E-mail: santana.everton005@gmail.com

${ }^{3}$ Estudante do curso de Administração, da Faculdade Metropolitana da Grande Recife.

E-mail: ligia.las@gmail.com
} 
innovation in a call center about the perspectives of employees and the challenges they face in the daily routine of the Cli-K company. The study aimed to identify the main points to be improved in terms of process innovation in the service sector and in employee training, highlighting the motivational factor to achieve productivity. The survey and analysis were carried out through field research, through a closed questionnaire, applied between 21 to 27/04/2021. Of the 71 people involved, $55(77 \%)$ participated in the questionnaire. In the theoretical context, the main basis was Chiavenato (2010). The study revealed how significant is the vision that employees have, as they work directly with customers on the front line, facing challenges, so it is essential that companies invest more and more in process innovation, in employee training, giving importance to the motivational factor to ensure the productivity and well-being of its employees.

Keywords: Process innovation. Call Center. Employee Challenges.

\section{REFERENCIAL TEÓRICO}

A inovação se constitui, hoje em dia, em uma estratégia essencial para o desenvolvimento de qualquer empresa, de qualquer porte. Enxergamos a inovação como símbolo de desenvolvimento e crescimento em um mercado cada vez mais competitivo. É comum, atualmente, que as empresas invistam em tecnologia, conhecimento e, acima de tudo, profissionais com perfil inovador.

A inovação pode se destacar de diversas formas, seja no produto, marketing, processos ou pessoas. A inovação de processos é de suma importância para a empresa que pretende se destacar dos seus concorrentes, uma vez que ela ganha mais flexibilidade e qualidade. Isso faz com que haja otimização do tempo de produção, garantindo maior eficiência e lucratividade.

Segundo Souza (2008), deve-se dar mais ênfase nas atividades que impactam no resultado final, seja um produto ou serviço, e não perder tempo com processos que não agregam valor ou resultado significativo.

\section{Inovação de processos no setor de serviços}

De acordo com Chiavenato (2010), a inovação tanto de processos quanto de produtos ou serviços traz ênfase à invenção e à aplicação, tornando-se como um apoio intensivo à qual se demonstra que as ideias inovadoras possibilitam melhoria contínua dentro das organizações.

Desta forma, é necessário ressaltar a importância da inovação nos processos de um Call Center, pois permite as correções de diversos problemas existentes dentro desse setor, sendo fundamental criar um clima organizacional que propicie a inovação, como:

a) Chamadas em espera que se refere à quantidade de consumidores que estão aguardando o atendimento. Falta de treinamento e feedbacks; 
b) Melhoria dos sistemas tecnológicos dos softwares, pois existem diversos sistemas para cada procedimento que reflete e muito nos indicadores;

c) Queda de ligação que causa insatisfação dos clientes e prejuízos para a empresa;

d) Tempo médio de atendimento que retrata o tempo de atuação de cada operador e o tempo médio de chamada que compreende desde o atendimento na URA (Unidade de Resposta Audível ${ }^{4}$ ) até a conclusão com o atendente.

Muitos colaboradores têm a percepção que é preciso às empresas desse ambiente inovar, justamente para evitar tantos transtornos que acabam resultando em enormes obstáculos dentro dessas organizações. Conforme descreveu Rissato (2004, p. 22): “O Call Center é o maior contribuinte para qualquer estratégia de marketing atual. A questão é que as empresas não aproveitam as informações que estão no Call Center para desenvolver suas estratégias".

Existem alguns fatores que contribuem para tal, porém é importante destacar os que mais favorecem para que as empresas consigam alcançá-los. Um fator determinante é a iniciativa de inovar, examinando as propostas que são consideráveis, controlando os seus efeitos e sempre fomentando para ter uma cultura inovadora. Outro ponto importante a respeito do assunto é justamente o de adotar medidas que viabilizem estratégias de negócios para aperfeiçoar os processos e oferecer ações que tenham planejamento que tragam mudanças positivas, pois é válido submeter uma empresa a ter um ambiente estruturado. É de extrema necessidade alcançar toda a esfera organizacional, ou seja, envolver todos os níveis de hierarquia, expandindo também para que chegue até os clientes, mantendo o foco no relacionamento com eles para fidelizá-los. Com isso é possível garantir, de forma satisfatória, o oferecimento dos serviços. Como apontou Davila, Epstein e Shelton (2007):

Organizar para a inovação continua a ser um desafio de grandes proporções para
muitas empresas. Não é suficiente desenvolver uma estratégia ou elaborar processos
de inovação; é indispensável construir e incutir a inovação no tecido geral da
organização. Inovação bem-sucedida exige escolher, elaborar e preparar a
organização adequada e as pessoas certas para executar e intensificar a inovação. (DAVILA; EPSTEIN; SHELTON, 2007, p. 104).

Deve-se levar em consideração que o setor de Call Center desempenha um papel essencial porque transmite um canal de interação entre a empresa e o usuário e que através dele os clientes podem fazer reclamações, elogios, esclarecer suas dúvidas, realizar compras ou cancelar, ou até mesmo fornecer sugestões de melhoria. Rissato (2004, p. 23) diz que "É fundamental gerar resposta do mercado por meio de estímulos eficazes e superar as expectativas do cliente quando ele bater à sua porta, seja por meio de um Call Center, da

${ }^{4}$ URA - Unidade de Resposta Audível: sistema de autoatendimento automático que permite a interação direta com o usuário por meio de menus preestabelecidos, recebendo comando e enviando informações. 
internet, seja pessoalmente". Visando esses aspectos, é necessário salientar a notoriedade dos benefícios que a inovação traz, contudo encontram-se alguns processos inovadores existentes dentro dos Call Centers, como a própria URA, Chat online, os Chatbots ${ }^{5}$ que integram as redes sociais (Instagram, Facebook, Linkedln, Twitter, You Tube e Whatsapp). Os operadores interagem e respondem aos usuários, sejam com mensagens prontas ou não, mas é preciso incorporar enriquecimento que incremente melhorias, pois muitos clientes ainda optam em realizar ligações por não conseguir o que deseja, seja por ter dificuldade de uso, por falhas dos sistemas ou por despreparo dos funcionários. A esse respeito, Rissato (2004) diz que "Na verdade, ninguém deve implantar um CRM (Customer Relationship management), mas sim melhorar os processos no relacionamento com seus Clientes. A tecnologia, o software, deve ajudá-lo no processo, e não o contrário".

\section{Capacitação de colaboradores no segmento de serviços}

Sem sombra de dúvida, é nítido que cada colaborador seja uma peça-chave para uma boa produtividade na empresa ou na prestação de serviços, porém para que as atividades sejam exercidas de forma eficiente e eficaz é necessário que passem por capacitações para que estejam aptos no desenvolvimento de suas atividades. Segundo Marras (2000), o treinamento produz um estado de mudança no conjunto de conhecimentos, habilidades e atitudes de cada colaborador, uma vez que o programa modifica a bagagem particular de cada um. Por isso, é de grande relevância capacitar os colaboradores para evitar situações que os mesmos não consigam resolver, seja por não terem conhecimento ou por não se sentirem confiante o suficiente.

Para Chiavenato (2010, p. 367), “através do treinamento - e do desenvolvimento -, a pessoa pode assimilar informações, aprender habilidades, desenvolver atitudes e comportamentos diferentes e desenvolver conceitos abstratos". Portanto, é conveniente orientá-los para que saibam qual linguajar usar ou qual postura adotar, pois irão lidar com diversas personalidades e tipos de clientes. Pessoas bem treinadas muitas vezes desenvolvem estratégias e habilidades que ajudam bastante na resolução dos processos. Por esse motivo torna-se essencial às organizações estarem engajadas a darem espaços para que os funcionários possam adquirir conhecimento e aplicá-los.

Mancini (2006) sintetiza a questão de capacitação de operadores afirmando que

\footnotetext{
${ }^{5}$ Um Chatbot é um software capaz de manter uma conversa com um usuário humano em linguagem natural, por meio de aplicativos de mensagens, sites, e outras plataformas digitais.
} 


\begin{abstract}
O bom atendimento é construído sobre bons processos [...] o sucesso depende de um conjunto de atributos, que começa pela definição estratégica que orientará todas as ações da empresa em relação aos seus clientes, fornecedores e colaboradores internos [...] processos de integração entre departamentos, trânsitos e circulação das informações, implantação de ações baseadas nessas informações e seu gerenciamento para produzir satisfação, eficiência e fidelização. Fundamental neste processo é a capacitação do pessoal linha de frente, do operador que estará em contato direto com o cliente, com o prospect $^{6}$ (cliente em potencial) ou usuário, pois as mídias eletrônicas ainda não criaram um ambiente de interatividade total para atender pedidos, aceitar perguntas, críticas, sugestões etc.. (MANCINI, 2006, p. 76).
\end{abstract}

Tachizawa et al. (2006) salientaram que investir no desenvolvimento das pessoas que realizam o trabalho nas organizações significa investir na qualidade dos produtos e serviços e, consequentemente, atender melhor os clientes e ampliar as vendas. Desse modo, é possível perceber o quão significativo são os conceitos a respeito da capacitação dos profissionais, sendo essencial investir em treinamento, orientando os funcionários a seguir a política da empresa, trazendo ações que possibilitem que os mesmos se desenvolvam. Por essa razão é de extrema urgência que as organizações tenham o desejo de investir na capacitação dos profissionais porque assim irão conseguir assegurar o retorno que almejam, ampliando o conhecimento dos colaboradores para que apresentem os produtos ou serviços com total confiança.

Torquato e Toledo (2016) falam da importância de não somente planejar, mas também ter um conceito a respeito das principais concepções que orientam as empresas a terem um dimensionamento, fazendo referências as estruturas oferecidas pelas organizações em processos de capacitação de seus profissionais. Marras (2000) apontou que através de programas de treinamento e de desenvolvimento a empresa deverá buscar e criar as competências necessárias para esse desenvolvimento do trabalho e assim gerar o resultado esperado através das competências a serem desenvolvidas. Lamentavelmente, muitas empresas cobram de seus funcionários produtividade, qualidade na prestação de serviço, exigem que as metas estabelecidas sejam alcançadas, mas não dão um treinamento capacitando o funcionário de como e quando devem agir para alcançar tais resultados. A falta desse suporte acaba gerando insatisfação por parte dos colaboradores.

Para Reginatto (2004), o treinamento ajuda as pessoas a serem mais eficientes, evitando erros, melhorando atitudes e alcançando maior produtividade. Por meio dele pode-se aprender fazendo, reavaliando e mudando comportamentos. Mas como capacitar de forma adequada os colaboradores de Call Center? Independente das circunstâncias que existem ou que possam existir, é fundamental buscar alternativas que ultrapassem os obstáculos porque não adianta

\footnotetext{
${ }^{6}$ Um prospect é um potencial cliente qualificado, que deve se adequar a certos critérios .
} 
realizar diversas demandas de treinamentos e não colher os frutos desejados. Desse modo, é preciso enfatizar alguns pontos relevantes que evidenciam a obter melhores resultados:

a) Estimular uma cultura de inovação que dissemine o conhecimento, valores e políticas da empresa, buscando os perfis corretos que se encaixe no processo apresentado;

b) Identificar os problemas, planejar, sanar e coletar informações através de entrevistas ou questionários que identifiquem os principais gargalos que necessitam ser tratados;

c) Avaliar os resultados sempre verificando a relação entre os custos e os benefícios, se a empresa obteve retorno, agregou valor ou conseguiu aumentar a produtividade;

d) Controlar os processos, analisando a melhor maneira possível de orientar os funcionários a atender os clientes;

e) Orientar os funcionários para que ofereçam um atendimento humanizado e que adotem boas práticas tendo empatia, boa comunicação, utilizando os nomes dos clientes ao se reportar para eles. Devem-se deixar de lado os famosos scripts, evitando padronizações.

A capacitação de serviços requer processos que projetem, apliquem e aperfeiçoem. Medidas como essas fazem com que as organizações desse segmento cheguem a um patamar favorável de resultados precisos, estruturado e, principalmente, a um desenvolvimento contínuo de seus funcionários. Pacheco et al. (2005, p. 18) citam que "o treinamento profissional diz respeito à preparação do indivíduo, com a assimilação de novos hábitos, conhecimento, técnicas e práticas voltadas para a satisfação de demandas no exercício da profissão". Alguns funcionários das empresas de Call Centers em estudo demonstraram aparentemente estarem insatisfeitos com o trabalho que desempenham, pois estão sempre reclamando sem motivos. Além de reclamarem do serviço, não dão ouvidos quando seus supervisores tentam resolver a situação. Schaufeli, Dijkstra e Vazquez (2013) ressaltam que:

\footnotetext{
É possível encontrar pessoas com pouco entusiasmo para realizar as coisas. Elas não são engajadas e, definitivamente, não são viciadas em trabalho. Algumas pessoas trabalham em atividades que não gostam e se sentem entediadas ou infelizes por isso; o dia de trabalho parece durar para sempre e elas se arrastam de um intervalo no trabalho para o outro porque não se sentem desafiadas pelas atividades que realizam. (SCHAUFELI; DIJKSTRA; VAZQUEZ, 2013, p. 24).
}

\section{Motivação e produtividade}

A motivação é algo individual, ninguém motiva ninguém, ela é interna. Gestores ou líderes podem realizar ações de estímulos, desencadeando o grau de satisfação dos indivíduos consigo mesmo. No entanto, existe um elo entre a motivação e a produtividade que para obter faz-se necessário promover ações inovadoras que levem as pessoas a se motivarem. 
Sobretudo, é preciso incentivá-las provocando a motivação. Chiavenato (2010) destacou como um dos maiores objetivos a serem alcançados pelas organizações, justamente o de tentar motivar as pessoas, fazê-las decididas, confiantes e comprometidas a atingir o que thes forem propostos. Campelo (2014) retratou como um grande desafio para nossa evolução a dificuldade de lidar e compreender o comportamento das pessoas com dois sentidos opostos: pode ser algo maravilhoso e gratificante, porém bastante intenso e desafiador. Um colaborador motivado produz mais em pouco tempo porque almeja demonstrar seu desempenho seja para obter um crescimento ou um reconhecimento dentro da empresa ou até mesmo receber uma bonificação pela sua produtividade. Enquanto que um funcionário desmotivado costuma causar conflitos porque adota uma postura descomprometida, não se empenha em atingir os objetivos propostos pela organização, deixando de atender as solicitações, ou até mesmo prestando um atendimento de baixa qualidade, tratando os clientes com descaso, além de afetar também seus colegas, contagiando-os ou induzindo-os a seguir o seu exemplo.

As organizações devem compreender a necessidade de dar atenção especial ao fator motivacional para obterem produtividade. Conforme Chiavenato (2010, p. 2421) "A motivação é um processo psicológico básico. Juntamente com a percepção, atitudes, personalidade e aprendizagem, a motivação sobressai como um importante processo na compreensão do comportamento humano". Entretanto, existem alguns pontos importantes a serem organizados pelas empresas, em todos os níveis de hierarquia. Proporcionar estratégias inovadoras que possam sair do plano e serem executadas, estabelecendo indicadores que permitam alguns elementos específicos que propiciam a motivação e produtividade, tais como reconhecimento, agradecimentos, realização de eventos comemorativos, um lembrete do aniversário do profissional, brindes, bonificações e aceitar sugestões dos colaboradores. Torna-se nítido que as organizações desejam que os seus colaboradores executem o que lhe foi solicitado, contudo é necessário criar uma estrutura que retrate um ambiente apropriado para isso. Bes e Capaverde (2019) mencionam que:

\footnotetext{
Para que uma organização realize o que se propõe a fazer, seja na prestação de um serviço ou na produção de algum bem, precisa, obrigatoriamente, de uma estrutura adequada e de um esforço ordenado na utilização de seus recursos tangíveis e intangíveis. Assim, as pessoas despontam na atualidade como o principal ativo capaz de levar a organização a atingir os seus objetivos. Porém, uma organização é complexa, e a forma como ela se estrutura produz determinado sentimento entre as pessoas que a integram. (BES; CAPAVERDE, 2019, p. 60).
}

Há diversas vantagens para as empresas que oferecem um ambiente pertinente para que pessoas se motivem, então é imprescindível traçar objetivos que estimulem os 
colaboradores a sentir essa sensação. Buscar procedimentos que promovam uma cultura organizacional transparente, realizar feedback não somente para apontar as falhas, mas para enriquecer o conhecimento dos funcionários, indicando o caminho certo, tendo essa interação para converter em uma maneira infalível que permita aumentar a produtividade e executar atividades que envolvam a equipe em busca de soluções, respeitando o desempenho de cada um. Tadeucci (2020) reforça a necessidade de ter um ambiente adequado para os colaboradores ao citar que:

O funcionário precisa de um ambiente propício para demonstrar sua capacidade de realização da tarefa. Uma máquina quebrada, instrumentos e ferramentas obsoletas levam à baixa produtividade e consequentemente a desmotivação. As condições de higiene do espaço físico de trabalho, alimentação, pausas para repouso todos esses aspectos interferem no nível de motivação. (TADEUCCI, 2020, p. 72).

De maneira geral, torna-se oportuno acolher as queixas dos funcionários para promover condições necessárias que desenvolvam práticas integradas, assim permitindo chegar ao nível motivacional e percorrer em melhores resultados que refletem na produtividade também. Portanto, para que haja um equilíbrio é preciso simplificar os processos que dificultam a atuação da equipe, pois a produtividade elevada conduz a motivação a um crescimento.

Tadeucci (2020) acentuou alguns aspectos que interferem na motivação, tais como:

a) O que é preciso fazer para que as pessoas despertem interesses que as levem ao fator motivacional?

b) Quais são os seus desejos?

c) O que elas consideram como uma boa recompensa?

São pontos que simplificam a necessidade de compreender e abordar soluções que viabilizem um dimensionamento que facilite o autoconhecimento e as relações interpessoais, focando nos pontos como esses para obter o alcance das metas estabelecidas porque o trabalho é desgastante. Não é fácil lidar diariamente com uma variedade de personalidades de diversos clientes, com várias cobranças internas, além dos problemas que surgem externamente, fora das organizações, como os pessoais. Então é válido que os gestores das empresas de Call Centers se preocupem com a motivação não somente como um todo, no coletivo, mas também individualmente, e realizem campanhas bem qualificadas que envolvam os colaboradores a ter interesse de participar e de exercer um bom desempenho, desse modo irão obter a produtividade desejada. Segundo Tadeucci (2020, p. 18), "as pessoas podem ter resultados mais gratificantes, ou não, em suas metas e objetivos pessoais, à medida que se sentirem mais motivadas, capazes, e tiverem condições em seu ambiente para atingir as suas expectativas". 
Criar desafios é a proposta mais comum dentro de uma operação de Call Center. É necessário reconhecer o trabalho, elogiar o desempenho, seja individual ou da equipe, e escutar os profissionais.

\section{METODOLOGIA}

Este artigo está embasado em uma pesquisa bibliográfica e de campo, com a finalidade aplicada, com método de análise propositiva e abordagem qualitativa, com coleta de dados por meio de um questionário fechado constante no apêndice.

O campo investigativo foi no Grupo Cli-K Telecom ${ }^{7}$, em Recife. O universo foi de 71 colaboradores, sendo 2 analistas de recursos humanos, 6 supervisores administrativos, 4 supervisores operacionais e 59 operadores. Destes, 55 participaram, ou seja, uma amostra de $77 \%$, com um erro amostral de $23 \%$.

\section{DESENVOLVIMENTO DA PESQUISA DE CAMPO}

Quais formas a empresa possui que contribuem para uma cultura organizacional inovadora?

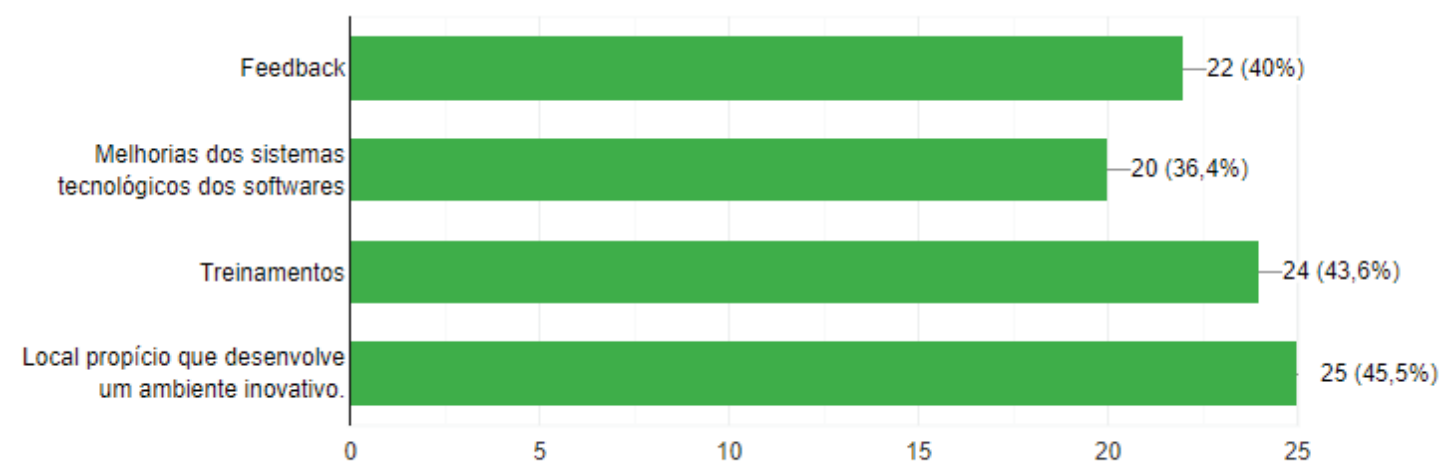

Nesta questão, 43,6\% dos inquiridos afirmaram que o treinamento é uma das principais estratégias para se criar um ambiente inovador na organização, algo bastante compatível com o que foi afirmado por Davila, Epstein e Shelton (2007), demonstrando, portanto, o valor e força que a capacitação de funcionários tem na elevação de uma cultura inovadora de atuação.

\footnotetext{
${ }^{7}$ Campo investigativo: Grupo Cli-k Telecom. Ano de fundação/criação: 2008. Mercado de atuação: Call Center. Localização: Rua Gervário Pires, N²34, Sala 101, Boa Vista, Recife - PE.
} 
Existem práticas utilizadas pela empresa que estimule a inovação?
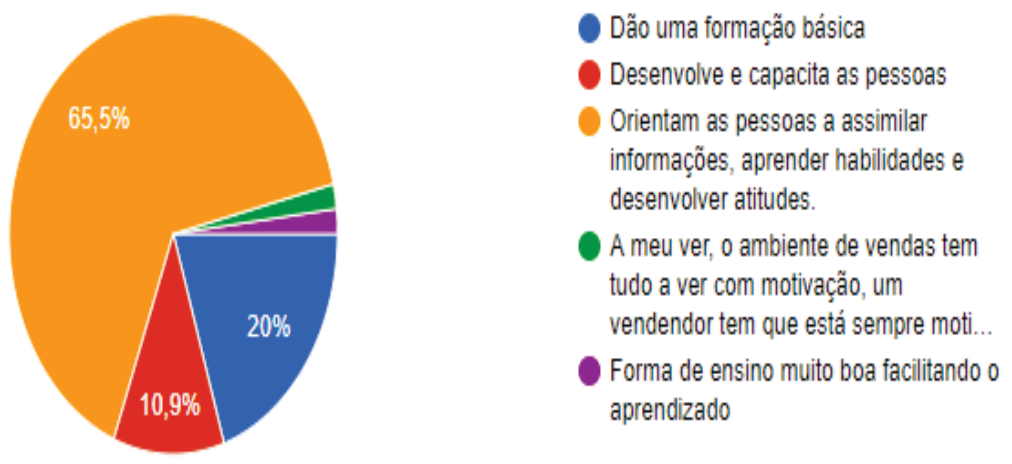

$65,5 \%$ dos inquiridos informaram o quão importante é orientar as pessoas para que a empresa consiga um ambiente que estimule a inovação, algo semelhante ao que Chiavenato (2010) apresentou. Ressalta-se também a necessidade de desenvolver para que elas assimilem, aprendam habilidades e comportamentos diferentes.

Justifique a sua escolha referente à resposta da questão anterior ou cite alguma sugestão:

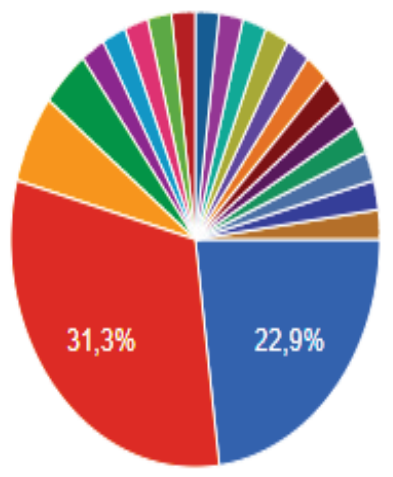

Justifique sua resposta

Sugestão

Existe um período de treinamento ond..

Fazem dinâmicas interessantes que e...

Desenvolve os colaboradores nas sua..

acredito que há mais formas de agreg..

Ensinam as técnicas de vendas e co...

Com treinamentos

A $1 / 3$

Nesta questão, 31,3\% dos respondentes salientaram que é preciso a empresa adquirir novas ideias para criar um ambiente que estimule a inovação, paralelo ao que citou Tadeucci (2020). É importante promover ações que contribuam para obter um local propício à inovação. 
Encontra-se algum controle de proteção para evitar que uma ideia inovadora seja copiada por outra empresa?

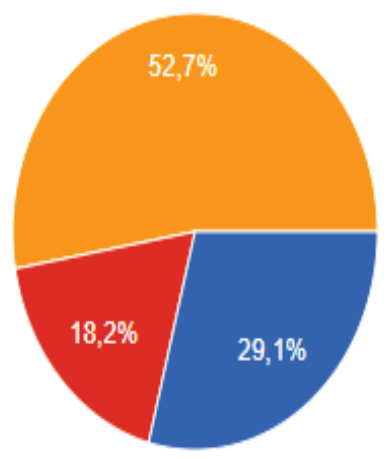

Existe um controle, mas não evita que as ideias sejam copiadas.

Não existe nenhum controle

A empresa adota medidas de controle e de proteção de forma eficiente

$52,7 \%$ dos inquiridos ressaltaram a relevância em relação a proteger uma ideia inovadora, correspondente ao que mencionaram Bes e Capaverde (2019), destacando, contudo, a forma como a empresa se estrutura para garantir o que se propõe.

A empresa possui programas de capacitação ou qualificação profissional?

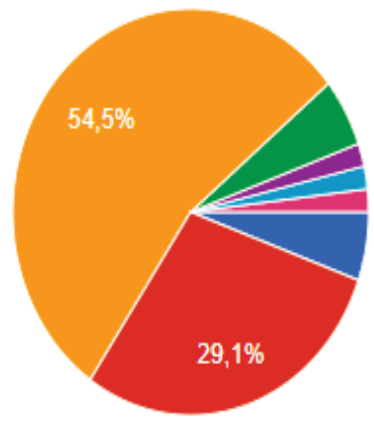

Sim, investe na capacitação dos profissionais

Possuem programas de treinamento e de desenvolvimento

Direciona um caminho que garante qualidade, eficiência e produtividade

Não há programas de capacitação ou...

Nao tem nenhum curso de capacitação

Não, que eu saiba.

Treinamento teórico e prático.

$54,5 \%$ dos participantes afirmaram como são preciosos os programas de capacitação e qualificação profissional, pois garantem um caminho de qualidade e eficiência, resultando na produtividade, conciliável com que foi citado por Marras (2000).

Existe algum ambiente dentro da empresa que propicie os colaboradores a se motivarem?

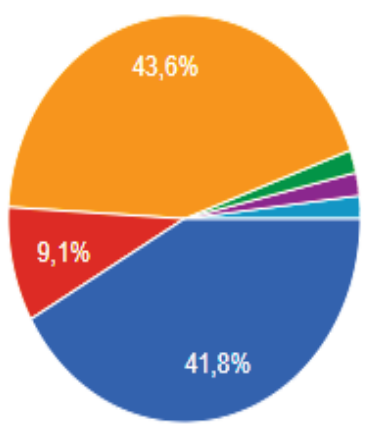

Existem eventos comemorativos

A empresa realiza feedbacks diários

Os gestores elogiam o desempenho dos colaboradores

todas as alternativas acima

Festa de final de ano

Campanhas semanais 
Torna-se nítida a visão que os inquiridos possuem referente ao fator motivacional, pois $43,6 \%$ demonstraram a necessidade da existência de eventos comemorativos, enquanto 41,8\% ressaltaram a importância dos gestores elogiarem o desempenho dos funcionários, algo bastante semelhante com que foi retratado por campelo (2014).

Os operadores possuem autonomia para tomar decisões durante o atendimento ou para realizar um atendimento humanizado?

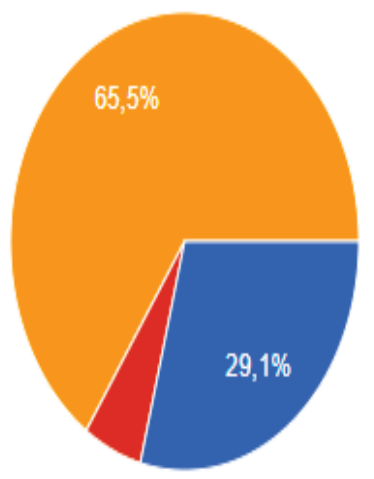

Sim, existe atendimento humanizado e os operadores recebem autonomia para tomar decisões.

Os operadores não possuem nenhuma autonomia no atendimento

Existe um controle quando às tomadas de decisões, porém os operadores possuem autonomia no atendimento humanizado

Nesta questão, 65,5\% dos entrevistados afirmaram a relevância de terem autonomia durante o atendimento, recebendo apoio de seus superiores, paralelo com o que sintetizou Mancini (2006). É fundamental essa autonomia dos operadores nas tomadas de decisões durante os atendimentos, pois eles são o pessoal da linha de frente.

Existem faixas salariais diferenciadas conforme habilidade ou produtividade dos colaboradores?

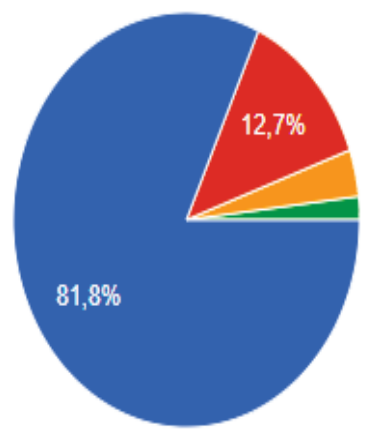

Sim, de acordo com a produtividade

Não existe

Existe para quem possui habilidade

Salário é igual, mais tem comissão para os melhores resultados.

$81,8 \%$ dos inquiridos informaram a importância de premiar os colaboradores conforme suas habilidades e produtividade, semelhante ao que citou Tadeucci (2020) a respeito dos fatores que contribuem para que os colaboradores alcancem suas expectativas. 
A empresa adota alguma rotina de trabalho que propicie os funcionários a captar informações importantes para a inovação?

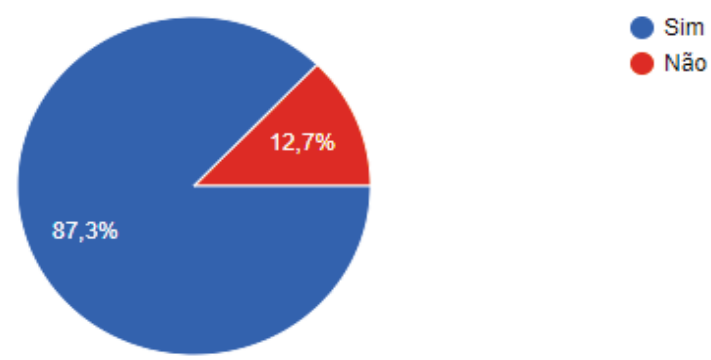

Nesta questão, 87,3\% dos participantes afirmaram que é preciso as empresas possuírem uma rotina de trabalho que vise captar informações pertinentes à inovação, compatível com o que foi citado por Chiavenato (2010). Por isso, faz-se necessário criar uma rotina de trabalho que propicie a inovação, pois irá possibilitar melhoria contínua dentro da empresa.

Os colaboradores recebem remuneração extra pelo seu desempenho ou produtividade?
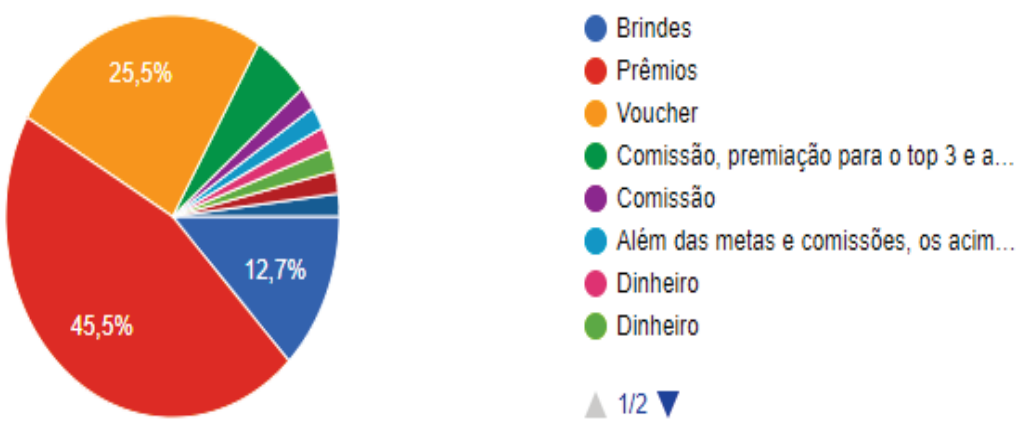

$45,5 \%$ dos participantes pontuaram a necessidade das empresas adotarem campanhas que realizem remuneração extra, seja pelo desempenho ou pela produtividade, paralelo ao que mencionou Tadeucci (2020), ressaltando o fator remuneração. Isso acaba gerando motivação, um ótimo desempenho e uma boa produtividade.

Existe reconhecimento por partes dos gestores?
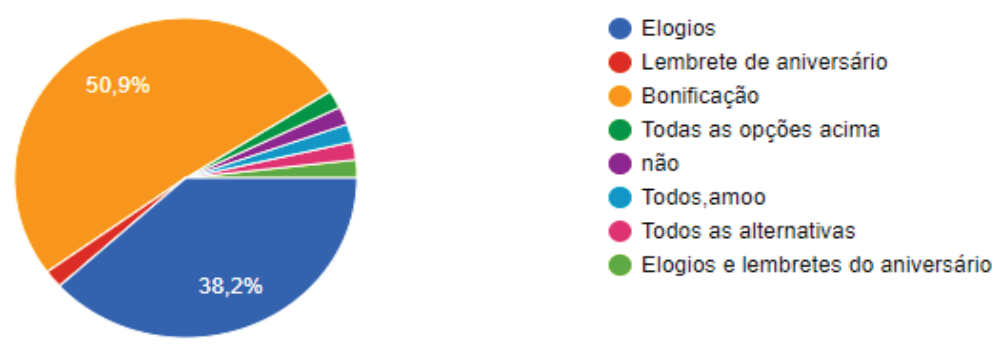
$50,9 \%$ dos participantes destacaram o quão significante são as medidas que viabilizem o reconhecimento. Schaufeli, Dijkstra e Vasquez (2013) reforçaram essa ideia, afirmando que é muito importante realizar processos que foquem no fator motivacional, abordando ideias engajadas que contribuam para reconhecer as pessoas em seu local de trabalho.

Os gestores aceitam ou acatam sugestões dos colaboradores?

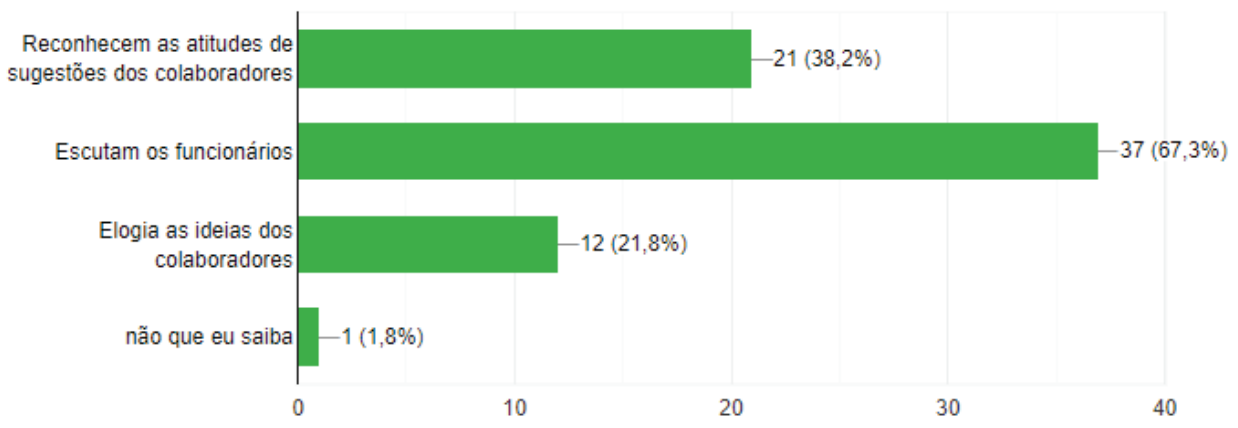

$67,3 \%$ dos inquiridos afirmaram a importância dos gestores ouvirem os seus colaboradores, algo bem compatível com o que foi abordado por Rissato (2004). Torna-se evidente o quão relevante é o fato dos gestores escutarem seus funcionários, pois dentro do Call Center, os que mais recebem informações são os colaboradores, logo é necessário saber aproveitar essas informações e transformá-las em estratégias.

\section{CONSIDERAÇÕES FINAIS}

Este artigo buscou identificar e analisar os principais problemas existentes dentro de um Call Center, através da visão dos colaboradores, e assim contribuir para que existam melhorias dentro desse segmento. Foi possível identificar e observar o quão essencial foram os resultados obtidos e como eles podem contribuir para pesquisas futuras, servindo como base para as demais pessoas que necessitem se aprofundar e ampliar os seus conhecimentos. A empresa analisada em Recife - PE, Cli-K, tem um papel relevante, pois visa alcançar um processo inovativo e, assim, entender e analisar as expectativas de seus colaboradores. A pesquisa ressalta o quão significante é a participação dos colaboradores para uma melhor compreensão sobre os métodos que devem ser utilizados para obter uma excelente resolução.

Diante do que foi analisado, recomenda-se caminhos a serem seguidos para obter êxitos na inovação de processos em um Call Center, ressaltando pontos fundamentais de melhorias na capacitação e no fator motivacional dos colaboradores que atuam em um na empresa pesquisada, tais como: implantação de programas de capacitação e treinamento para desenvolver os funcionários, realizando feedback construtivos para entendê-los e assim 
orientá-los da melhor forma possível, utilizando métodos que façam com que os colaboradores interajam, e com isso se motivem a querer participar, através de algumas ações, um simples elogio, premiações, bonificações ou campanhas bem estruturadas que despertem o comprometimento de todos para conseguir alcançar a produtividade dos funcionários, destacando também um local propício para a inovação.

\section{REFERÊNCIAS}

BES, Pablo; CAPAVERDE, Caroline Bastos. Planejamento em gestão de pessoas. Porto Alegre: SAGAH, 2019.

CAMPELO, Arandi Maciel. Gestão de pessoas: compreendendo o comportamento humano nas organizações. 6. ed. Recife: FCAP Books, 2014.

CHIAVENATO, Idalberto. Gestão de pessoas. 3. ed. Rio de Janeiro: Elsevier, 2010.

. Comportamento organizacional: a dinâmica do sucesso das organizações. 3 . ed. Rio de Janeiro: Elsevier, 2010.

DAVILA, Tony; EPSTEIN, Marc J.; SHELTON, Robert. As regras da inovação: como gerenciar, como medir e como lucrar. Porto Alegre: Bookman, 2007.

Guia Completo. Chatbots: o que é, como funciona, benefícios e cases. Disponível em: HTTPS://take.net/blog/chatbots/chatbot. Acesso em: 01 nov. 2020.

MARRAS, Jean Pierre. Administração de recursos humanos: do operacional ao estratégico. 14. ed. São Paulo: Saraiva, 2011.

MANCINI, Lucas. Call Center: estratégia para vencer. 2. ed. São Paulo: Summus Editorial, 2006.

PACHECO, Luiza et al. Capacitação e desenvolvimento de pessoas. Rio de Janeiro: Ed. FGV, 2005.

REGINATTO, Antonio Paulo. Equipes campeãs: potencializando o desempenho de sua equipe. 2. ed. Porto Alegre: Ed. SEBRAE/RS, 2004.

RISSATO, Marcelo. O cliente por um fio: o que você precisa saber sobre marketing e Call Center. São Paulo: Nobel, 2004.

SCHAUFELI, W. B.; DIJKSTRA, P.; VAZQUEZ, A. C. O engajamento no trabalho. São Paulo: Ed. Casa do Psicólogo, 2013.

SOUZA, Balzani. Gestão de processos. v. 4. Paraná, (PR): Sebrae, 2008.

TADEUCCI, Marilsa de Sá Rodrigues. Motivação e liderança. Curitiba: Ed. Brasil S. A., 2011. 
TACHIZAWA, Takeshy et al. Gestão com pessoas: uma abordagem aplicada às estratégias de negócios. 5. ed. Rio de Janeiro: FGV, 2006.

TIDD, Joe; BESSANT, John. Gestão da inovação. 5. ed. Porto Alegre: Bookman, 2015.

TORQUATO, Diomar Pedro; TOLEDO, Jair Fiuza. Descomplicando as telecomunicações nas empresas: Dimensionamento e métricas em PABX e Call Centers. São Paulo: Laços Ltda., 2016.

\section{APÊNDICE A - Modelo do instrumento de coleta de dados e informações}

1. Quais formas a empresa possui que contribuem para uma cultura organizacional inovadora?

02. Existem práticas utilizadas pela empresa que estimule a inovação?

03. Justifique a sua escolha referente à resposta da questão anterior ou cite alguma sugestão:

04. Encontra-se algum controle de proteção para evitar que uma ideia inovadora seja copiada por outra empresa?

05. A empresa possui programas de capacitação ou qualificação profissional?

06. Existe algum ambiente dentro da empresa que propicie os colaboradores a se motivarem?

07. Os operadores possuem autonomia para tomar decisões durante o atendimento ou para realizar um atendimento humanizado? conforme a habilidade ou produtividade dos colaboradores?

09. A empresa adota alguma rotina de trabalho que propicie os funcionários a captar informações importantes para a inovação?

10. Os colaboradores recebem remuneração extra pelo seu desempenho ou produtividade?

11. Existe reconhecimento por partes dos gestores?

12. Os gestores aceitam ou acatam sugestões dos colaboradores? (a) Feedbacks. (b) Melhorias dos sistemas tecnológicos dos softwares. (c) Treinamento. (d) Local propício que desenvolve um ambiente inovativo. (e) Outros.

(a) Dão uma formação básica. (b) Desenvolve e capacita às pessoas. (c) Orientam as pessoas a assimilar informações, aprender habilidades e desenvolver atitudes. (d) Outros.

(a) Justificativa: (b) Sugestão:

(a) Existe um controle, mas não evita que as ideia sejam copiadas. (b) Não existe nenhum controle. (c) A empresa adota medidas de controle de proteção de forma eficiente. (d) outros

(a) Sim, investe na capacitação dos profissionais. (b) Possuem programas de treinamento e de desenvolvimento. (c) Direciona um caminho que garante qualidade, eficiência e produtividade. (d) Outros.

(a) Existem eventos comemorativos. (b) A empresa realiza feedbacks diários. (c) Os gestores elogiam o desempenho dos colaboradores. (d) Outros

(a) Sim, existe atendimento humanizado e os operadores possuem autonomia para tomar decisões. (b) Os operadores não possuem nenhuma autonomia no atendimento. (c) Existe um controle quanto às tomadas de decisões, porém os operadores possuem autonomia para realizar um atendimento humanizado. (d) Outros

(a) Sim, de acordo com a produtividade. (b) Não existe. (c) Existe para quem possuem habilidades. (d) Outros.

(a) Sim. (b) Não.

(c) Sugestão

(a) Brindes. (b) Prêmios. (c) Voucher. d) Outros

(a) Elogios. (b) Lembrete de aniversário. (c) Bonificação (d) Outros.

(a) Reconhecem as atitudes de sugestões dos colaboradores.

(b) Escutam os funcionários. (c) Elogia as ideias dos colaboradores. (d) Outros 


\title{
INTOLERÂNCIA ÀS RELIGIÕES AFRO-BRASILEIRAS NO ESTADO DEMOCRÁTICO DE DIREITO: PERSPECTIVA DA TEORIA RADICAL
}

https://dx.doi.org/10.48097/2674-8673.2022n6p10

\author{
Thiago Luiz Dias Siqueira ${ }^{1}$ \\ Eduardo Pessoa Crucho Cunha ${ }^{2}$
}

\begin{abstract}
RESUMO
O presente artigo pretende demonstrar que o tema criminologia radical é de legítimo interesse e relevância na sociedade. A abordagem está baseada nos casos concretos dos processos judiciais em que os réus são de religiões antagônicas, a qual o poder judiciário sopesou a balança do Direito a favor do cristianismo e desfavoreceu a religião de matriz africana em casos de extrema semelhança. Buscase averiguar o motivo pelo qual as religiões afro-brasileiras são discriminadas no mundo jurídico, uma vez que todos são iguais perante a lei, de acordo com a Constituição Federal de 1988, onde traz à baila o princípio da impessoalidade, pois a administração não pode tratar o indivíduo de maneira diferente por conta de questões ideológicas a não ser que esteja de acordo com o princípio da isonomia. Costumeiramente, na prática, as religiões não cristãs são marginalizadas. É imposto pelo grupo dominante um padrão de comportamento no qual as minorias não se encaixam. $\mathrm{O}$ direito penal passa então a ser uma ferramenta de controle social. Para que o modelo de conduta social atribuído pelos mais fortes seja seguido por todos é necessário que a norma penalizadora intervenha. A criminologia radical é uma aplicação do método em Marx para a compreensão do crime e do controle social. Ela busca compreender a realidade não por curiosidade, mas pelo compromisso declarado com o fim da desigualdade social.
\end{abstract}

Palavras-chave: Criminologia radical. Karl Marx. Intolerância. Religiões de matriz africana.

Data de submissão: 06/08/2021

Data de aprovação: 13/10/2021

\begin{abstract}
The present work intends to demonstrate that the radical criminology theme is interesting and relevant for society. The approach is based on concrete cases of legal proceedings in which the defendants are of antagonistic religions, in which the judiciary has tipped the balance of Law in favor of Christianity and disfavored the African-based religion in cases of extreme similarity. It seeks to investigate the reason why Afro-Brazilian religions are discriminated against in the legal world, since everyone is equal before the law, according to the Federal Constitution of 1988, which brings to light the principle of impersonality, as the administration cannot treat the individual differently on account of ideological issues unless it is in accordance with the principle of isonomy. Usually, in practice, non-Christian religions are marginalized. A pattern of behavior in which minorities do not fit is imposed by the

\footnotetext{
${ }^{1}$ Discente do Curso de Bacharelado em Direito da Faculdade Metropolitana da Grande Recife.

E-mail: thiagoluiz22198@gmail.com

2 Docente orientador do Curso de Bacharelado em Direito da FMGR.

E-mail: eduardocruchoprof@gmail.com
} 
dominant group. Criminal law then becomes a tool for social control. In order for the model of social conduct attributed by the strongest to be followed by all, it is necessary for the penalizing norm to intervene. Radical criminology is an application of Marx's method to understanding crime and social control. It seeks to understand reality not out of curiosity, but out of a declared commitment to ending social inequality.

Keywords: Radical Criminology. Karl Marx. Intolerance. African matrix religions.

\section{INTRODUÇÃO}

O presente artigo científico é resultado de uma pesquisa realizada para a apresentação e defesa do Trabalho de Conclusão de Curso, cujo tema abordado é a discriminação das religiões de matrizes africanas. Pela perspectiva desta escola criminológica, surge a tentativa de encontrar um adequado entendimento do crime, do criminoso e do fenômeno da criminalidade, dentro do contexto sócio-político e econômico em que se produzem.

Desta forma, o tema escolhido demonstra que além do discurso de ódio, há, também, um controle social através da norma penal, causando disparidade jurídica a quem por diversas circunstâncias seja adepto ou não de religião afro-brasileira em relação ao grupo étnico (classe social) dominante. A criminologia Radical é uma aplicação do método em Marx para a compreensão do crime e do controle social. Chama-se "criminologia radical" pelo fato desta teoria buscar a resposta que tanto procura na raiz do fenômeno "crime x controle social". Ela busca compreender a realidade não por curiosidade, mas pelo compromisso declarado com o fim da desigualdade social. Esta teoria tenta explicar que o crime vai além de um problema causador de prejuízo social, um rótulo que os grupos dominantes estabelecem aos dominados, ou seja, conflitos decorrentes de classes antagônicas.

A norma penal está a serviço da parcela social dominadora, detentora do poder políticoeconômico, passando então a ser a justiça penal apenas administradora da criminalidade, devido à escassez de meios para combatê-la. A norma penal se restringe em selecionar a sua “clientela" costumeira, ficando nítido que o crime é um meio para obter o controle social em meio à criação de leis penais. O fenômeno da criminalidade decorreria da incapacidade do Estado em prover os recursos necessários para que o cidadão tenha uma vida de acordo com os padrões sociais.

\section{CONTEXTO HISTÓRICO DA INTOLERÂNCIA Às RELIGIÕES AFRO- BRASILEIRAS}


No período que compreende o século XIII até a metade do século XIX, época da Inquisição, havia perseguições contra as mulheres, pela Igreja Católica. Nestes séculos, muitas delas foram queimadas vivas em locais públicos por serem acusadas de bruxaria e de praticarem atos demoníacos. Conforme Rose Muraro explica na obra Malleus:

\begin{abstract}
A partir do fim do século XIII, o feudalismo é obrigado a centralizar e hierarquizar o poder para se manter e se organizar com métodos políticos e ideológicos mais modernos. A Igreja Católica e a Protestante foram importantes para essa centralização do poder, e de acordo com a autora, o fizeram através dos tribunais da Inquisição, que varreram a Europa, torturando e assassinando em massa aqueles que eram julgados hereges ou bruxos. (MURARO, 1999 apud PIRES, 2013, p. 564).
\end{abstract}

Desta maneira, a autora busca explicar como a sociedade se organizava, demonstrando que os valores cristãos eram impostos à população através da força. Este objetivo colocaria dentro das regras de comportamento dominante as pessoas que trabalhavam no campo, exploradas, muitas vezes, aos excessos de seus senhores, a mercê das pestes, da guerra, e que se mostrava principalmente nas mulheres.

De acordo com a autora, "essa perseguição não foi uma histeria coletiva, mas sim uma perseguição muito bem elaborada pelas classes dominantes para centralizar o poder”. Muraro tenta explicar que é possível enxergar um controle social neste período, já que o grupo atormentado era composto por mulheres, e que supostamente praticavam atos contrários aos valores impostos pela sociedade cristã. (MURARO, 1995, p. 15).

Visto isto, em tempos mais à frente, já no século $\mathrm{XX}$, período do Brasil fascista (da era Vargas), é notório a axiologia católica do século XIII - XIX. O chamado Estado Novo fez-se perpetuar no Brasil, especialmente no estado de Pernambuco, a cultura persecutória do catolicismo em detrimento das religiões afro-brasileiras. O Interventor Agamenon Magalhães, um católico fervoroso, na época responsável pelo governo de Pernambuco (de 1937 a 1945), teve a sua política pautada na perseguição à cultura afro-brasileira, especialmente as religiões de matrizes africanas. Neste momento histórico, o papel da imprensa teve extrema importância, já que se tornou um instrumento de referência na interventoria de Agamenon Magalhães. Esta foi a estratégia fundamental para construir os valores do Estado Novo em Pernambuco. Desta forma, era a própria confirmação da verdade imposta pelo interventor, da legitimidade, do discurso da competência e da inteligência do Estado. O jornal Folha da Manhã, em que o governador era dono, foi o porta-voz do seu governo. Para tanto, esse instrumento de comunicação utilizava os temas mais relevantes através do sensacionalismo em detrimento da problemática social dos quais recebeu particular atenção os adeptos de religiões afro-brasileiras, identificados como casos de polícia. Desta maneira, afirma Zuleica Campos (2009): 
Foi na República, com o Decreto de 11 de outubro de 1890, que o Estado criou maneiras de regular o combate aos catimbós, elaborando no Código Penal. Três artigos que diziam respeito a esta questão: o artigo 156, que se refere à prática ilegal da Medicina; o artigo 157, que estabelece como crime a prática do Espiritismo, da Magia, da Cartomancia, do uso de talismãs, como também a de subjugar a credulidade pública; e, por fim, o artigo 158, que pró́be a prática do curandeirismo. (CAMPOS, 2009, p. 308-309).

A autora tentar contextualizar o momento que a sociedade brasileira vivenciou, podendo se chegar à conclusão que o Estado teve o objetivo de controlar a sociedade, impondo o comportamento padrão imposto pelo grupo étnico dominante, para isso se utilizando do Direito como ferramenta.

$\mathrm{O}$ Estado, deste modo, intervia nos assuntos relacionados à magia para censurar os feiticeiros, acusando, criando juízos especiais e pessoas especializadas para combater tais práticas. Conforme os anos passavam, instituições foram criadas na polícia para combater este comportamento, identificando e punindo os praticantes.

Assim, esta medida do Estado veio a ser usada de maneira intensa em Pernambuco, apoiando-se no Capítulo 2 da Constituição Federal dos Estados Unidos do Brasil de 1937. O artigo 122, parágrafo 4, afirma que "todos os indivíduos de diferentes confissões religiosas podem exercer pública e livremente o seu culto, associando-se para esse fim e adquirindo bens, observadas as disposições do direito comum, as exigências da ordem pública e dos bons costumes.” (BRASIL, 1937).

No artigo 141, deste mesmo Capítulo, se encontra:

$7^{\circ}$ Parágrafo - É inviolável a liberdade de consciência e de crença e assegurado o livre exercício dos cultos religiosos, salvo os que contrariem a ordem pública ou os bons costumes. As associações religiosas adquirirão personalidade jurídica na forma da lei civil.

$8^{\circ}$ Parágrafo - Por motivo de convicção religiosa, filosófica ou política, ninguém será privado de nenhum dos seus direitos, salvo se o invocar para se eximir de obrigação, encargos ou serviços impostos pela lei aos brasileiros em geral, ou recusar os que ela estabelecer em substituição daqueles deveres, a fim de atender escusa de consciência. (BRASIL, 1937).

A lei, nesta época, era usada para impor o padrão comportamental de âmbito religioso do grupo dominante em detrimento das minorias. O ataque ao "catimbó" tinha uma justificativa "legal". Desta forma, o poder se eximia do que era praticado, mas acabava incorporando a crença. Se existiam catimbozeiros, feiticeiros, embusteiros, é porque se acreditava na feitiçaria.

Foi escolhido o Catolicismo como religião oficial do Brasil, na tentativa de apagar da sociedade todas aquelas práticas religiosas que "ameaçavam" a doutrina social cristã, propagada na época. A Folha da Manhã, jornal local de propriedade de Agamenon 
Magalhães, veiculava a doutrina proposta através do processo de "catequização" da sociedade. Os afro-umbandistas deveriam ser desconstruídos, marginalizados e, finalmente, silenciados. Uma ideia foi a de mostrar à população, através da mídia, as operações praticadas pela polícia. Tais operações eram compartilhadas pelo periódico em questão, rotineiramente, no período de 1938 a 1945. Eram muitas matérias, com o objetivo de doutrinar, educar, alertar a sociedade para o mal dessas práticas, apresentadas como malignas e criminosas. Na gazeta, os afro-umbandistas eram tratados com expressões preconceituosas, como catimbozeiros, curandeiros, feiticeiros perigosos, exorcistas, embusteiros, exploradores, patifes, covardes sem escrúpulos, malandros, cavadores de vida fácil.

Essa perseguição foi além da religião. Ela tinha relação com a axiologia racista evidenciada pela política do então interventor federal. O preconceito contra os afrodescendentes e sua cultura evidenciava-se em vários aspectos, sendo claro o etnocentrismo arraigado no ordenamento jurídico.

\section{TEORIA RADICAL: RELAÇÃO COM AS RELIGIÕES AFRO-BRASILEIRAS}

A Criminologia Radical é uma aplicação do método em Marx para a compreensão do crime e do controle social. Chama-se "criminologia radical" pelo fato desta teoria buscar a resposta que tanto procura na raiz do fenômeno "crime x controle social. Ela busca compreender a realidade não por curiosidade, mas pelo compromisso declarado com o fim da desigualdade social. Esta teoria estuda o processo criminalizador, mostrando através de desenvolvimentos seletivos da construção social do comportamento criminoso e de seres humanos rotulados, como forma de assegurar desigualdades comunitárias entre capital e poder nas sociedades atuais. Esta escola afirma que a solução para a problemática do delito depende da abolição da exploração econômica e da arbitrariedade política sobre as classes dominadas. Neste sentido, Santos (2008) arremata:

\footnotetext{
São tarefas complementares da política criminal alternativa da criminologia radical: (a) Conjugar os movimentos de presos com as lutas dos trabalhadores; (b) Inverter a direção ideológica dos processos de formação da opinião pública radical e a difusão de informações sobre a ideologia de controle social; (c) coordenar as lutas contra o uso capitalista do estado e a organização capitalista do trabalho; e (d) desenvolver o contra poder proletário. (SANTOS, 2008, p. 132).
}

Conforme a teoria acima se insurge outro pensamento: a premissa do etiquetamento social, que entende que o delito vai além de um problema causador de prejuízo social, mas de uma etiqueta que os grupos dominantes estabelecem aos dominados, ou seja, conflitos decorrentes de classes antagônicas. 
Nesta concepção, surge então a questão das religiões afro-brasileiras no estado democrático de direito, visto que a Constituição Federal, em seu preâmbulo, afirma ser o Brasil um país laico quando menciona Deus. Estado irreligioso é aquele no qual o poder público decide por lei que ele não pode nem favorecer e nem prejudicar o exercício de qualquer religião. Cabe indagar: como um país pode ser laico se existe o controle social exercido pelo sistema capitalista? Desta maneira, no imaginário social, o criminoso será sempre o outsider (alguém extracomunitário, um desviante, minoria se comparado com a maioria). Os adeptos de religiões afro-brasileiras tornam-se então a minoria em uma sociedade padronizada pelos cristianismos católico e evangélico.

\section{Efeitos jurídicos, morais e sociais da intolerância às religiões afro-brasileiras no ordenamento jurídico}

Abre-se a questão da sociedade excludente e um direito baseado no formalismo crítico quando se coloca o indivíduo de fora do grupo por não seguir o padrão de religião imposto pelo sistema capitalista. Isto é visto com clareza no poder legislativo brasileiro, já que a extrema direita sempre articulou toda uma vertente de evangélicos para quem as religiões afro-brasileiras são inaceitáveis, o que cria uma situação potencialmente perigosa para a dita laicidade do Estado. O grupo conservador de direita se torna um problema quando ele pode fazer parte de uma maioria, uma vez que a bancada evangélica favorece a construção de várias pautas conservadoras, sobretudo na esfera dos costumes. O avanço deste grupo põe em risco a democracia no que se refere às religiões de matrizes africanas. É escancarada a discriminação que sofre tais religiões e já parece ser o direito baseado em um formalismo crítico, isto é, a norma penal passa a valer para uns e não para todos. Este fato está nítido na própria mídia, conforme pode ser visto em uma reportagem de um caso ocorrido em 2012:

\footnotetext{
A Justiça condenou a cinco anos e quatro meses de prisão, em regime semiaberto, Edmar Santos de Araújo, o Pai Bruno da Pombagira, por estelionato, extorsão e formação de quadrilha. O motoboy dele, Alex Alberto de Souza, também foi condenado a quatro anos e dez meses, em regime igual, e pelos mesmos crimes.

Os dois foram presos em flagrante, em junho deste ano, após ameaçarem e extorquirem um homem que havia procurado o falso pai de santo para que ele fizesse um trabalho para recuperar a pessoa amada em três horas.

De acordo com a vítima, Edmar e mais duas secretárias começaram a exigir, através de contato telefônico, o pagamento de novas quantias para que o trabalho de feitiçaria fosse terminado. A vítima, desconfiada de que se tratava de um golpe, procurou a polícia.

Em sua defesa, o réu Alex alegou que somente cumpriu com o seu trabalho de motoboy. Já Edmar alegou que não há estelionato na conduta daquele que oferece providência espiritual, por ser um tema atinente à fé, constitucionalmente assegurado.

Para o juiz Vinícius Marcondes de Araújo, da $27^{\mathrm{a}}$ Vara Criminal, a conduta dos réus deixa clara a demonstração de má fé e do dolo de estelionato e extorsão. Em sua decisão, o magistrado afirmou que se explora a ingenuidade, a fragilidade e a boa fé alheia por cobiça financeira.
} 
"Da prova colhida não resta a menor controvérsia sobre a existência do fato de que o acusado Edmar - "pai Bruno" - oferecia o trabalho espiritual atinente a trazer a pessoa amada em 3 horas, invocando a intervenção do Diabo. Outrossim, o próprio conteúdo da obrigação "trazer a pessoa amada em 3 horas (não são nem os tradicionais 3 dias vistos em cartazes por aí)" corrobora a convicção de que o objetivo de pai Bruno era enganar, o que se afere in re ipsa. Se assim fosse, musas e atores famosos badalados pela mídia estariam perdidos, diante da legião de fãs que dizem amá-los. Os trariam em 3 horas. Isso não é razoável ou factível". (Omeionorte.com, 2012, p. 01).

É necessário salientar que o direito não deve favorecer nem desfavorecer ninguém por motivos ideológicos. Conforme arremata Carvalho (2020), o princípio da impessoalidade

se traduz na ideia de que a atuação do agente público deve-se pautar pela busca dos interesses da coletividade, não visando a beneficiar ou prejudicar ninguém em especial - ou seja, a norma prega a não discriminação das condutas administrativas que não devem ter como mote a pessoa que será atingida pelo seu ato. Com efeito, o princípio da impessoalidade reflete a necessidade de uma atuação que não discrimina as pessoas, seja para benefício ou para prejuízo. Dessa forma, é possível considerar que, ao Estado, é irrelevante conhecer quem será atingido pelo ato, pois sua situação é impessoal. O agente fica proibido de priorizar qualquer inclinação ou interesse seu ou de outrem. Esse é um aspecto importante baseado no princípio da isonomia. Para Celso Antônio Bandeira de Mello, a "administração deve tratar a todos sem favoritismos, sem perseguições, simpatias ou animosidades políticas ou ideológicas". (CARVALHO, 2020, p. 72-73).

Neste sentido, o autor busca enfatizar que o Estado não pode deixar a impessoalidade diante de tal atuação. $\mathrm{O}$ agente fica proibido de priorizar qualquer inclinação ou interesse seu ou de outrem. Esse é um aspecto importante da impessoalidade baseado no princípio da isonomia. A administração deve tratar a todos sem favoritismos ideológicos. Enquanto a balança da norma penal pesa mais contra os adeptos de religiões afrodescendentes, os cristãos e, principalmente, os ditos evangélicos, recebem outro tipo de tratamento quando raramente são acusados por questões de charlatanismo barato.

Em se tratando de crimes contra o patrimônio é necessário analisar outro crime, o de ameaça, que é necessário para se atingir o crime de extorsão. Tendo como fundamento a veracidade do fato, Greco (2017) arremata:

Quando a própria lei penal, ao definir o delito de ameaça, diz que o mal prometido deve ser injusto e grave, implicitamente está querendo traduzir a ideia, também, de mal verossímil, ou seja, aquele que pode ser efetivamente produzido. Ameaçar alguém, por exemplo, dizendo-lhe que fará com que um raio caia sobre a sua cabeça está completamente fora das possibilidades de ser realizado, afastando-se, outrossim, o crime. (GRECO, 2017, p. 468).

É possível ver que em todas as ameaças está ausente o elemento de verossimilhança, fazendo o tipo penal de ameaça ser descabível em tal caso, visto que o diabo ou qualquer entidade não possui validade jurídica pelo fato da decisão ter sido prolatada no século XXI e não na idade média onde se caçavam as bruxas. Para um homem médio tal superstição não tem comprovação alguma no plano científico, haja vista que o direito é ciência e não dogma. 
A Ciência é o conhecimento que explica os fenômenos, obedecendo às leis que foram verificadas por métodos experimentais. A ciência baseia-se na regularidade, na previsão e no controle de fenômenos que podem ser observados.

A doutrina explica que é necessário que a ameaça se concretize para que seja possível a extorsão existir no plano real. Greco (2017) afirma:

os elementos que integram o delito de extorsão, a saber: a) constrangimento,
constituído pela violência física (vis corporalis) ou grave ameaça (vis compulsiva),
obrigando a vítima a fazer, tolerar que se faça ou a deixar de fazer alguma coisa; b)
especial fim de agir, caracterizado pela finalidade do agente em obter indevida
vantagem econômica, para si ou para outrem. Conforme destaca Hungria: "O meio
mais comumente empregado para a extorsão é a grave ameaça, e, tal como no roubo,
não há distinguir se o mal prometido é, em si mesmo, injusto ou não. Não há
confundir o crime de ameaça (art. 147) com a ameaça como meio executivo de
crime: no primeiro caso, é necessário que o mal ameaçado seja injusto; no segundo,
é indiferente que possa ser, ou não, infligido secundum ius. Ainda que se tenha
direito à inflição de um mal, a ameaça de exercê-lo torna-se obviamente contra jus
quando empregada como meio à prática de um crime. É preciso, porém, não
confundir o caso em que o mal é, em si mesmo, justo, e injusta a vantagem
pretendida, e o em que, injusto o mal, é justa a vantagem pretendida: no primeiro, há
extorsão; no segundo, não, apresentando-se o crime de violento 'exercício arbitrário
das próprias razões' (art. 345 ). Assim, será este o crime cometido, v.g., pelo
proprietário que obtém do ladrão, sob ameaça de morte, a restituição da res furtiva,
já na sua posse tranquila. Existe extorsão ainda quando o agente, tendo alguém sob
coação legítima, lhe exija vantagem para fazer cessá-la, ex.: o particular que prende
um criminoso em flagrante, exige dele, a seguir, a entrega de dinheiro para libertá-
lo. (GRECO, 2017, p. 707).

O autor busca explicar, de forma técnica, que a extorsão precisa do tipo penal elencado no artigo 147 do código penal como meio executivo, nos casos narrados pelas vítimas, as "ameaças" não se enquadram, visto que eram despidas de verossimilhança, pois não é provado cientificamente que o diabo ou qualquer outra entidade exista, sendo, portanto, um mal impossível de se praticar.

Já no que diz respeito ao estelionato não se enquadra ao caso, já que foi dito em audiência de instrução que os trabalhos espirituais foram devidamente realizados. O réu usou itens para a concretização do feito, comprando animais para sacrifício e etc., o que leva por si só um custo, sem falar o serviço que foi prestado.

Um exemplo da disparidade de tratamento jurídico dado é visto no caso em que o pastor Valdemiro Santiago comercializava sementes de feijão por valores entre cem reais a mil reais, sob o argumento de que teriam eficácia terapêutica para a cura da Covid-19, mesmo em casos graves. A sentença do juiz federal Tiago Bitencourt de David, determinou que a União informasse no site do Ministério da Saúde, em até 15 dias, se há ou não eficác ia comprovada das sementes de feijão no combate à Covid-19. O magistrado tomou o devido cuidado de 
jogar uma responsabilidade totalmente desnecessária à União para que a sua decisão não fosse só sua, em relação a um caso extremamente óbvio. Desta forma, Affonso (2020) arremata:

\begin{abstract}
Em sua decisão, o juiz afirmou que "é preciso considerar que a liberdade de crença não pode ser indevidamente restringida pelo Estado e nem este pode ser cooptado por entidade religiosa, pois a Constituição Federal estabelece que o Estado é laico, não combatendo a profissão de fé e nem incorporando-a no próprio governo, de modo que os fiéis não têm mais ou menos direitos que os ateus". Para o juiz, se uma pessoa deseja gastar seu dinheiro de um modo e não de outro, isso é assunto dela, "não podendo o Estado dizer que ela é ignorante e não sabe fazer boas escolhas". Mas, diz o magistrado, apresentar os dados significa dar condições para que a população "escolha de modo informado e consciente". Ele entende que cabe à União "informar a população acerca da (in) eficácia curativa do feijão apresentado como abençoado e alegadamente dotado de poder restaurador da saúde". Na opinião do juiz, o governo "deve informar de forma cuidadosa e respeitosa, neutra, limitando-se a dizer que (não) há eficácia comprovada do produto no que tange à Covid-19". A Justiça Federal determinou ainda que a Google preserve os vídeos e informe o endereço na internet de quem os postou nas redes sociais. (AFFONSO, 2020, p. 01).
\end{abstract}

Desta maneira, o sistema penal se torna cada vez mais um instrumento usado pelo grupo dominante, já que a extrema direita articula toda uma vertente evangélica. Caso a fé religiosa seja muito intensa, ela pode transbordar para a moral, sendo inevitável que os evangélicos queiram que todos tenham a mesma fé que a sua. Outra coisa é querer que certas pessoas respeitem determinados princípios morais, dos quais estão convencidos que são universais. Um exemplo seria o caso de um evangélico ultra pentecostal: ele não vai querer que todo mundo pare de pecar, mas se ele acreditar que o aborto é uma afronta à norma penal, isso será algo que ele vai querer que todo mundo acredite. O contra-argumento de não se tentar impor a religião aos outros é fraco, pois caso convença-se de que um princípio individual é ético, e não religioso, mas sim ético e universal, e não só da religião individualizada, estar-se-á, neste caso, tentando que todos sejam descentes e para a decência individual neste exemplo seria a exclusão do aborto. Passa-se a ter uma contaminação de uma agenda política com a religião evangélica na sua vertente ética ou pseudo-ética.

\title{
METODOLOGIA
}

Este artigo, para sua confecção, contou com a pesquisa bibliográfica, quantitativa e exploratória, por meio de livros e periódicos físicos e virtuais. Devido à pandemia da covid-19 a pesquisa de campo foi realizada por meio de entrevista pelo Google Forms. O formulário foi enviado a 50 pessoas, entre profissionais da área jurídica e adeptos de religiões afro-brasileiras. Deste universo, 40 deles responderam, constituindo a amostragem da pesquisa.

\section{RESULTADOS DA PESQUISA DE CAMPO}

Abaixo seguem os gráficos com respostas das quatro questões que foram abordadas com os participantes da pesquisa. 
1. Sendo o Brasil um estado democrático de direito, e sua constituição afirma ser um país laico, você acredita que todas as religiões possuem o mesmo tratamento?

39 respostas

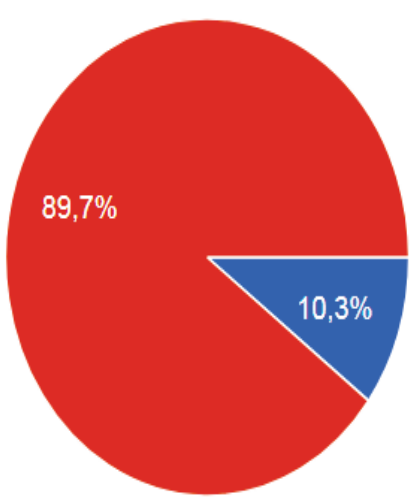

$\operatorname{Sim}$

Não

2. Você acredita que a sociedade brasileira vê com outros olhos os adeptos que não seguem um padrão de religião imposto pelo sistema capitalista?

40 respostas

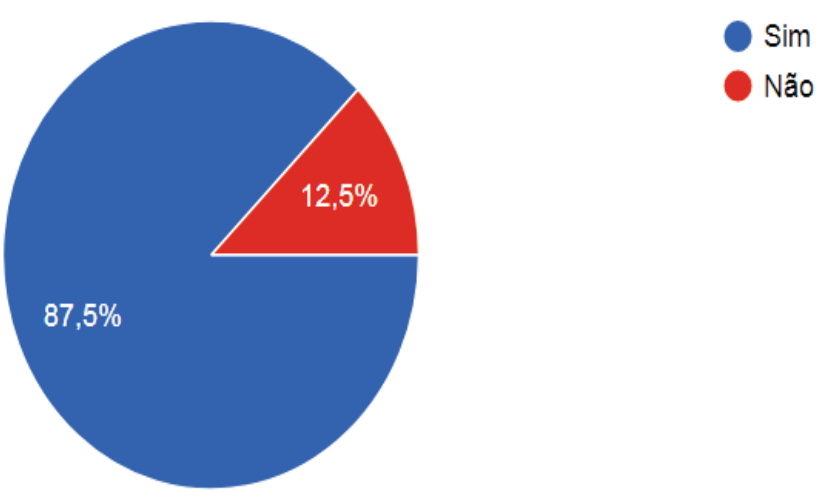


3. Você acha que pode haver uma tendência a punições mais severas quando o réu for adepto de religiões afro-brasileiras?

40 respostas

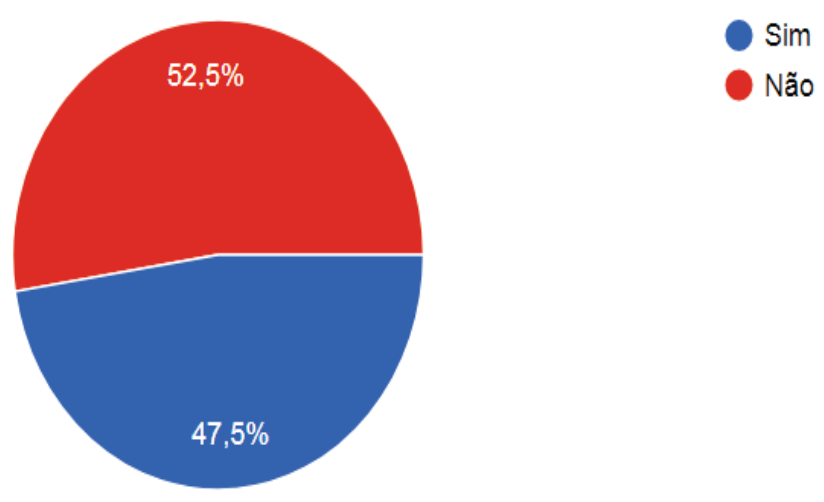

4. A justiça deve tratar a todos sem favoritismos ideológicos. Você acredita que isso sempre acontece?

39 respostas

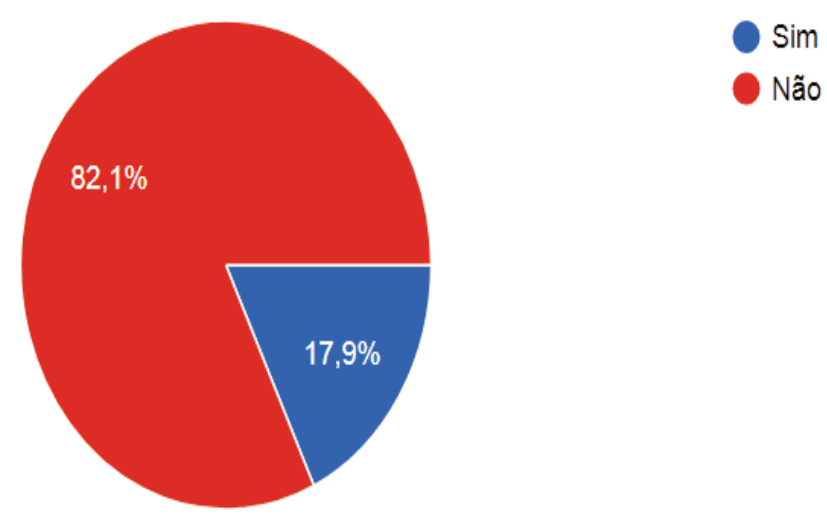

\section{CONSIDERAÇÕES FINAIS}

Este artigo científico teve como objetivo apresentar à sociedade um fenômeno social explicado sob a ótica da Escola Radical Criminológica, tendo o seu argumento ganhado propulsão através do ordenamento jurídico, ao destacar a intolerância religiosa. Tal fato também torna-se evidente ao serem observados os dados coletados pela pesquisa de campo. Desta forma, a pseudolaicidade do Estado brasileiro surge como tema a ser discutido em dois casos concretos entre religiões diferentes e seu tratamento desigual em casos similares, 
mostrando-se, então, uma fragilidade na democracia. O controle social através da norma penal causa disparidade jurídica a quem por diversas circunstâncias seja adepto de religião afrobrasileira ao invés da religião do grupo dominante. A Teoria Radical explica que o crime vai além de um problema causador, de prejuízo social, mas de um rótulo que os grupos dominantes estabelecem aos dominados, ou seja, conflitos decorrentes de classes antagônicas. O direito passa a se basear em um formalismo crítico, isto é, a lei vale para uns e não para outros. O interesse da classe favorecida pelo capital faz do Direito um mero instrumento para obter o controle social. Tudo o que era estável e sólido desmancha-se no ar, tudo o que era sagrado é profanado, e os homens são obrigados a encarar com olhos desiludidos seu lugar no mundo e suas relações recíprocas.

Conclui-se, desta forma, que é possível crer que o dito Deus mencionado no preâmbulo da Constituição da República Federativa do Brasil é o Cristão. Como um país pode ser laico se o controle da sociedade é exercido pelo sistema capitalista? A Teoria Radical explica o sintoma social que aparece em decorrência da disparidade jurídica, uma verdadeira violação à substância jurídica proposta pelo texto constitucional, de maneira que a sociedade passa a se dividir em grupo dominante e grupo dominado, ou seja, o Direito vale para uns, não para outros.

\section{REFERÊNCIAS}

AFFONSO, Julia. Justiça manda Governo Federal informar no site do Ministério da Saúde de feijão do pastor Valdemiro Santiago cura Covid-19. Disponível em: https://g1.globo.com/sp/sao-paulo/noticia/2020/10/28/justica-manda-governo-federal informar-no-site-do-ministerio-da-saude-se-feijao-do-pastor-valdemiro-santiago-cura-covid19.ghtml. Acesso em: 21 nov. 2020.

BRASIL. Constituição dos Estados Unidos do Brasil. (10 de novembro de 1937). Disponível em: http://www.planalto.gov.br/ccivil_03/constituicao/constituicao37.htm. Acesso em: 20 nov. 2020.

CAMPOS, Zuleica Dantas Pereira. Revista Brasileira de História das Religiões - Ano I, n. 3, Jan. 2009 - ISSN 1983-2859 Dossiê Tolerância e Intolerância nas manifestações religiosas. A polícia no estado novo combatendo o catimbó. Disponível em:file://C:/Users/55819/Desktop/TCC/A\%20POL\%C3\%8DCIA \%20NO\%20ESTADO $\% 20$ NOVO $\% 20$ COMBATENDO $\% 200 \% 20$ CATIMB $\%$ C3\%93\%20Zuleica\%20Dantas\%20Pereir a\%20Campos.pdf. Acesso em: 07 nov. 2020.

CARVAlHO, Matheus. Manual de Direito Administrativo. 7. ed. Ver. Ampl. e atual. Salvador: JusPODVM, 2020. 
GRECO, Rogério. Curso de Direito Penal: parte especial, volume III . - 14. ed. Niterói, RJ: Impetus, 2017.

MURARO, Rose Marie. Prefácio. In: "Malleus Malleficarum: o martelo das feiticeiras" [1484]. Rio de Janeiro: Rosa dos Tempos, 1995.

Omeionorte.com. Pai Bruno da Pombagira é condenado a cinco anos de prisão. Disponível em: https://www.meionorte.com/policia/pai-bruno-da-pombagira-que-traria-amor-em-3 horas-econdenado-a-cinco-anos-de-prisao-188208. Acesso em: 21 nov. 2020.

SANTOS, Juarez Cirino dos. A criminologia radical. 3. ed. Rio de Janeiro: Lumen Juris, 2008. 


\title{
LIDERANÇA NAS ORGANIZAÇÕES: DESAFIOS DE MULHERES GESTORAS NOS DIAS ATUAIS
}

\author{
https://dx.doi.org/10.48097/2674-8673.2022n6p11
}

\author{
Arandi Maciel Campelo ${ }^{1}$ \\ Beatriz Gomes de Azevedo Pinheiro ${ }^{2}$ \\ Julia Maria da Silva ${ }^{3}$
}

\section{RESUMO}

Este artigo abordou o conceito sobre os desafios de mulheres gestoras nos dias atuais, retratando as dificuldades que esse público enfrenta em busca do seu espaço no mercado ocupacional trabalhista, em defesa do princípio da igualdade. A análise dos dados baseia-se nos resultados de estudos que foram realizados através de uma pesquisa qualitativa, com questionário semiaberto, no ano de 2021. Foram contemplados três campos investigativos com um total de 17 participantes. Uma empresa multinacional contemplou 2 participantes entre 4 existentes; o Condomínio do Shopping Center Guararapes contemplou 12 participantes entre 100 existentes; e a Clínica Amor Saúde contemplou 3 participantes entre 5 existentes. O referencial teórico teve como principal fonte Souza \& Cararo (2017). O estudo revelou a significância dos dados, pois nota-se que é imprescindível a inserção e consolidação absoluta da mulher nas atividades econômicas do mercado de trabalho para que, assim, encontre uma estruturação e iguale por competência e não por sexo e gênero a ocupação de cargos.

Palavras-chave: Liderança feminina. Desafios de mulheres gestoras. Inserção da mulher no mercado de trabalho.

Data de submissão: 22/09/2021

Data de aprovação: 09/11/2021

\begin{abstract}
This article addressed the concept of the challenges of women managers today, portraying the difficulties that this public faces in search of its space in the occupational labor market, in defense of the principle of equality. Data analysis is based on the results of studies that were carried out through a qualitative research, with a semi-open questionnaire, in the year 2021. Three investigative fields were covered with a total of 17 participants. A multinational

\footnotetext{
${ }^{1}$ Orientador: Doutor em Educação - Universidade Federal de Pernambuco; Administrador - Universidade de Pernambuco - FCAP/UPE; Mestre em Planificación y Gestion Organizacional - Universidad Autonoma de Madrid / Espanha; Mestre em Dirección y Organización de Hospitales y Servicios de Salud - Universidad Politécnica de Valencia / Espanha; Especialista em Marketing - FCAP/UPE; Consultor em Sistemas Organizacionais, desde 1984; Professor e Diretor Acadêmico da Faculdade Metropolitana da Grande Recife. E-mail: arandi.campelo@globo.com

${ }^{2}$ Estudante do curso de Administração da Faculdade Metropolitana da Grande Recife.

E-mail: beatrizazevedo.adm@gmail.com

${ }^{3}$ Estudante do curso de Administração da Faculdade Metropolitana da Grande Recife.

E-mail: juliamariada.silva@hotmail.com
} 
company contemplated 2 participants out of 4 existing ones; the Condominium at Shopping Center Guararapes included 12 participants out of 100 existing ones; and the Amor Saúde Clinic included 3 participants out of the 5 existing. The main source of the theoretical framework was Souza \& Cararo (2017). The study revealed the significance of the data, as it is noted that the insertion and absolute consolidation of women in the economic activities of the labor market is essential so that they can find a structure and equalize by competence and not by sex and gender the occupation of positions.

Keywords: Female leadership. Challenges of women managers. Insertion of women in the labor market.

\section{INTRODUÇÃO}

O tema escolhido para este artigo é de suma importância para demonstrar a evolução da mulher e as conquistas obtidas após as adversidades de inserção no mercado de trabalho, defendendo um dos pontos de mais relevância que é a importância da aplicabilidade dos direitos iguais, baseando-se no princípio da igualdade, dos direitos recebidos e protegidos a este público pela legislação brasileira.

\section{INSERÇÃO DA MULHER NO MERCADO DE TRABALHO}

Nos primórdios dos séculos XVIII e XIX as mulheres já nasciam predestinadas a serem a "mulher perfeita". Eram vistas apenas como a mãe de família, a senhora do lar, um perfil traçado apenas para satisfazer a vontade do homem e as necessidades da casa.

O ideal de mulher que é representativo a este tempo era visto como mulher geradora. Os atributos delegados a este público se tratavam da dependência e da sua atuação maternal, sendo treinadas e educadas apenas para servir a seus maridos em total submissão e demonstrar à sociedade uma imagem de modelo ideal de feminilidade, adotando uma conduta de personalidade emotiva, maternal, dependente e sexualmente passiva na relação conjugal.

Para atingir estes padrões se fazia necessário que abdicassem totalmente de suas necessidades pessoais e impossibilitassem a realização de outra conquista que não fosse de cunho familiar. Elas tinham apenas que alcançar os objetivos de ser uma boa esposa e mãe.

De acordo com Lerner (2020):

[...] A explicação tradicionalista concentra-se na capacidade reprodutiva feminina e vê a maternidade como a maior meta na vida das mulheres, definindo, assim, como desviantes mulheres que não se tornam mães. Considera-se a função materna uma necessidade da espécie, uma vez que as sociedades não teriam conseguido chegar à modernidade sem que a maioria das mulheres dedicasse quase toda a vida adulta a ter e criar filhos. Assim, vê-se a divisão sexual do trabalho com base em diferenças biológicas como justa e funcional. (LERNER, 2020, p. 38).

Sendo assim, ela era educada para ser uma doméstica, tendo apenas o dever de cumprir com compromissos voltados à família e ser omissa nas questões ligadas à chefia ou liderança. 
Não tinha voz ativa até mesmo dentro do seu lar. Carreira e poder andavam lado a lado apenas com a figura masculina. Seguindo esta perspectiva, considerava-se que, incontestavelmente, a mulher era inferior, cabendo a ela apenas o cultivo necessário de seus deveres naturais como cuidar dos filhos e obedecer ao marido.

A evolução das mulheres no mercado de trabalho se inicia após a Primeira (1914-1918) e a Segunda Guerra Mundial (1939-1945), pois estas foram essenciais para um despertamento e força de mudança radical na cultura comportamental que prevalecia anteriormente no mercado de trabalho da época. À frente do cenário em que os valores da sociedade se viram oprimidos pela ausência dos homens diante da tragédia avassaladora intitulada como o conflito militar mais mortal da história, o que trouxe a carga de milhões de mortes ocasionadas, as mulheres se viram tomadas de uma real necessidade de sobrevivência, exercendo funções que outrora cabiam só aos homens.

Foi em 1941 que a função preeminentemente masculina deu lugar ao público feminino. Durante a Segunda Guerra o alistamento militar foi permitido às mulheres. Estas atuaram muitas vezes disfarçadas de homens, guerreiras à frente de combates, mas também assumiram funções importantíssimas tais como operárias nas fábricas de armamentos e munições. Isso só comprova a força que as mulheres sempre tiveram, subordinando sua concepção de verdade e de valor ao sucesso e ao êxito em cada ação.

Para Souza e Cararo (2017):

[...] A participação feminina no Brasil Colônia (1500-1822) se restringiu, em parte, à procriação, aos trabalhos domésticos, ao canto e às orações. Nesse contexto, a alfabetização das mulheres seria fundamental para ampliar a atuação feminina na sociedade e mudar a história do país. [...] (SOUZA; CARARO, 2017, p. 12).

É possível afirmar que em 1980 pesquisas apontavam a grande e real presença do público feminino adentrando no mercado ocupacional trabalhista em áreas de serviços sociais, mas é importantíssimo salientar que mesmo alcançando a maior massa, concentração e prestação de mão de obra, estas mesmas mulheres sofriam com a grande desigualdade salarial, não gozando plenamente dos seus direitos trabalhistas impostos posteriormente.

Na visão de D'Ávila (2019), há quem diga que vivemos o fim da era do humanismo, o fim do ciclo das conquistas da Revolução Francesa, e com isso, o fim de um sentimento construído historicamente com a revolução: a empatia, o colocar-se no lugar do outro, o sentir que o outro é igual.

Ao longo da história comprova-se que as mulheres suportaram e vivenciaram tudo o que a sociedade impôs inalcançável a este público. Elas experimentaram, sofreram, sobreviveram 
e sustentaram todas as atrocidades cometidas em guerra, nos campos de concentração. Para Souza e Cararo (2017):

[...] Enfrentar os preconceitos que mesmo no século XXI são tão presentes em nossa sociedade, dando conta também de tantos papéis e exigências, é, sem dúvida, prova de força. Prova. Essa palavra que nasce conosco e nunca nos abandona. (SOUZA; CARARO, 2017, p. 9).

De acordo com Scherer (2020), a representatividade feminina, seus avanços, conquistas e a capacidade que as mulheres possuem de construírem estratégias para guiar suas organizações ao mercado em tempos atuais, ainda apontam os desafios hoje enfrentados por elas ao adentrar no mundo organizacional, e que estes são fundamentais no papel de evolução, crescimento e participação das mulheres a serviço da sociedade mesmo após séculos passados, frisando a importância do bom relacionamento e trabalho em equipe; a cooperação, agindo contrariamente à competição. A autora afirma que:

Á medida que a sociedade vai se transformando, a função social da mulher vai se adequando a novos modelos. Surge a emancipação feminina, ou seja, uma busca pela igualdade de gêneros, nas relações da esfera do trabalho. Todo esse novo contexto acaba por modificar as formas como homens e mulheres condicionam suas competências a serviço da sociedade, não mais apenas da família e estendendo as atuações femininas ao mundo organizacional. (SCHERER, 2020, p. 13).

\section{Liderança feminina nas organizações}

Para Chiavenato (2004), liderança significa coordenar o desempenho dos colaboradores, sendo necessário para todo o tipo de organização humana, buscando obtenção de resultados almejados pela empresa, sendo necessário conduzir as pessoas.

As mulheres, a partir do século XIX, começaram a ser inseridas no mercado de trabalho. Com a primeira revolução industrial elas foram essenciais nas fábricas para o manuseio das máquinas. A partir daí, as mulheres foram ganhando seu espaço cada vez mais, porém, ainda com muito preconceito perante a sociedade.

Naquele tempo o salário das mulheres era muito inferior ao do homem, trabalhando muitas vezes em situações precárias, mas, sempre buscando ocupar seu lugar no mercado de trabalho. Elas ainda tinham que fazer dupla jornada: trabalhar fora e cuidar do seu lar e família.

Para D'Ávila (2019), essa cultura responsabiliza as mulheres pela jornada dupla de trabalho, impondo-lhes responsabilidades básicas como higiene da casa e cuidados com as crianças, como se homens fossem incapazes de lavar louça ou buscar seus filhos e filhas na escola. 
De acordo com Sina (2005), uma mulher tem dentro de si o dom de gerar outras vidas, mas ela precisa e quer ter sua identidade. Parece claro, mas não é. Ela tem a capacidade de se dividir entre várias atividades, além de conseguir entender diversos pontos de vista.

Para Ramal (2019), uma vez que a mulher é introduzida em ambientes que antes era apenas ocupado por homens, é notável que o mesmo não aprova essa inserção. Diante disto, a mulher prova que, independentemente de gênero, suas competências intelectuais e profissionais vão além de qualquer preconceito e discriminação. Conforme cita a autora:

Com o tempo acostumamo-nos à solidão e até mesmo aos semblantes sisudos daqueles que reprovam nossas incursões por estes ambientes. Sei que foi muito pior para a geração anterior à minha. Reconheço também, com orgulho, que estamos preparando o terreno para a próxima geração. É um esforço de semeadura que será recompensado. Em um futuro não tão distante as meninas de hoje encontrarão estruturas laborais menos intimidadoras. Estas profissionais serão menos desrespeitadas e assediadas, mais ouvidas e valorizadas. (RAMAL, 2019, p. 114).

A trajetória da mulher nos últimos séculos é de grande evolução. Sua presença é cada vez maior no mercado de trabalho, fazendo parte da educação escolar, tanto nos níveis médio, técnico e superior. Ela vem quebrando todos os rótulos, pois não é mais a mulher que trabalha apenas em casa, mas também em fábricas, comércios, empresas multinacionais, autônomas, empresárias, agricultoras, entre outras.

Conforme cita Xavier (2018), [...] "Liderança não é uma escolha, mas uma característica intrínseca e autêntica que nasce da capacidade de sonhar e de acreditar no seu próprio potencial de realização".

Segundo o IBGE (2016) (Instituto Brasileiro de Geografia e Estatística), as mulheres dedicavam $73 \%$ do seu tempo a mais do que os homens com afazeres domésticos e cuidados com as pessoas. $60,9 \%$ dos cargos gerenciais, tanto públicos quanto privados, eram ocupados por homens, enquanto $39,1 \%$ pelas mulheres. Já em relação aos rendimentos as mulheres recebem em média $3 / 4$ do que recebem os homens.

De acordo com Pereira (2019), as mulheres podem assumir com propriedade os papéis de liderança, mesmo que enfrentem obstáculos em questões dos preconceitos ligados ao gênero e pelos modelos de líderes impostos nos tempos passados. No geral, independentemente de gênero, os líderes devem ser sensíveis aos seus liderados, adaptando-se à realidade e trabalhando com êxito para cumprir o seu papel. Segundo Pereira (2019):

Você tem que ser modelo no seu trabalho. Seu chefe, seus supervisores devem ver você como exemplo a ponto de dizer aos novos contratados: "Olhem para esta mulher aqui. Aprendam com ela. Façam as mesmas coisas que ela faz! Essa pessoa é sempre pontual, tem boas atitudes, faz mais do que lhe é pedido". Isso é excelência! (PEREIRA, 2019, p. 135). 
De acordo com Scherer (2020), as mulheres constroem estratégias para guiar as organizações no mercado, assim liderando de modo único empresas ao sucesso. Elas enfrentam desafios do cotidiano em relação ao gênero, demostrando que conseguem superar cada obstáculo que encontram no mundo coorporativo.

\section{Vantagens competitivas da liderança feminina nas organizações}

É notório e propício afirmar que a validade de uma doutrina é determinada pelo seu êxito prático, ou seja, é do conhecimento geral que para ressaltar as vantagens competitivas da liderança feminina é necessário listar seus desdobramentos práticos no contexto em que a mesma se encontra diante da sociedade.

Analisando uma pesquisa realizada com 4.812 empresas, em 32 países, é possível afirmar que as instituições desprezam o potencial da competência feminina, pois de acordo com a pesquisa mais recente do International Business Report Grant Thornton, as mulheres no Brasil ocupam hoje 34\% dos cargos de liderança sênior (diretoria executiva), crescendo $9 \%$ em relação aos dados do ano de 2019 , quando o mesmo constava apenas com $25 \%$ dos cargos de liderança sendo ocupados por mulheres. Apesar dos dados comprovarem que nas últimas décadas houve um crescimento considerável quanto à ocupação de mulheres nos cargos de liderança, este mesmo estudo ressalta que o Brasil ocupa atualmente a $8^{\circ}$ colocação no ranking dos 32 países.

Ressaltando a mesma pesquisa e os dados nela existentes, no ano de 2019 o Brasil apresentou percentuais maiores quanto ao ano de 2020, vejamos: Diretor de recursos Humanos 32\% (31\% em 2019); Diretor Financeiro (CFO) 34\% (38\% em 2019); Diretor de TI 12\% (17\% em 2019); Diretor de Marketing 16\% (20\% em 2019), Controlador 8\% (9\% em 2019) e Diretor de Vendas 12\% (16\% em 2019).

É importante falar que ao logo dos anos o feminismo vem lutando para defender um objetivo: mostrar que as mulheres são tão eficazes quantos os homens para assumir quaisquer posições dentro das organizações, usando estratégias e medidas que ajudam a vencer as barreiras de gênero impostas por uma sociedade machista. Portanto, é necessário que as empresas e organizações trabalhem exercendo na prática uma cultura inclusiva em todas as esferas profissionais, e para isso é necessário um comprometimento com o todo.

Conforme o IBGE, as mulheres receberam salário médio de R\$2.050 por mês, o correspondente a $79,5 \%$ do rendimento do trabalho dos homens (R $\$ 2.579$ ). Os dados foram apresentados pela PNAD (Pesquisa Nacional por Amostra de Domicílios Contínua), o que comprova as diferenças de salários entre homens e mulheres. Isso traz à tona a realidade da 
desigualdade de gênero em todas as regiões do país. Não importa quão empenhadas sejam as mulheres ou a aptidão com que exercem as suas funções. A verdade é que este empenho e dedicação ao trabalho têm sido negligenciados pelas organizações, pois estas seguem um padrão ultrapassado de comportamentos ainda antiquados.

É possível afirmar que desempenho e capacidade profissional não têm sexo, gênero, raça ou até mesmo uma nacionalidade. É preciso exterminar esse padrão cultural ainda existente que a sociedade insiste em carregar. $O$ histórico de discriminação de gênero tem que ter fim.

Partindo então desse princípio, Souza e Cararo (2017) ressaltam que temos de provar tudo a todos o tempo inteiro, embora saibamos que ninguém nunca deveria ter de provar nada para garantir respeito e direitos iguais.

O IBGE (2020) divulgou uma estimativa da população residente nos 5.570 municípios brasileiros: 211,8 milhões de habitantes, crescendo 0,77\% em relação a 2019 e o público feminino é $52 \%$ da população. É notório que a população feminina é maior que a masculina, e crescente com os anos. A questão não é lutar para defender o domínio total de mulheres em cargos de liderança, mas diz respeito à igualdade de ambos os públicos, segundo o seu desempenho profissional. Hoje ainda nos deparamos no mercado de trabalho atual com mulheres na luta por reivindicações em busca de espaço.

O público feminino, por muitos anos, de forma opressiva e preconceituosa, foi intitulado e considerado fraco por ser flexível em diversas situações: por saber lidar com a necessidade de outras pessoas, olhar com sensibilidade e analisar uma melhor forma a situação, se adaptar às mudanças. Essas mesmas críticas foram acolhidas com sabedoria, pois as mulheres souberam fazer com que tirassem vantagens no mundo corporativo atual. A capacidade de motivar pessoas e o poder de influenciá-las a tomar melhores decisões as tornaram precisas e por quer não dizer analíticas. De acordo com Sandberg e Col (2013):

[...] Hoje, as empresas precisam da capacidade de ensinar, interagir, educar, relacionar-se e trabalhar em equipe. Somos sempre muito mais incentivadas que os homens a desenvolver todas essas características. As mulheres precisam se dar conta disso e agarrar a oportunidade. [...] (SANDBERG; COL, 2013, p. 39).

As dificuldades existentes incentivaram as mulheres a ir em busca de adaptação, mesmo dentro de suas limitações. O que não se pode deixar de ressaltar como algo importantíssimo é a jornada dupla da mulher, que mesmo após uma jornada profissional de trabalho ainda exerce uma outra jornada, que é a do ambiente familiar. Isso não a desmotiva a estar sempre a procura pela excelência.

Partindo deste princípio Sandberg e Col (2013) afirmam: 
[...] Claro que ainda há uma grande pressão para que a gente assuma comportamentos tipicamente masculinos para exercer o poder. Mas é preciso vencer essa imposição, assumir a feminilidade em cargos de chefia e mostrar que é possível ser tão — ou mais - competente sem adotar os padrões convencionais de administração, feitos por homens e para homens. A diversidade é fundamental. As mulheres que confiam em seu próprio poder, conhecimento, estilo e personalidade conseguem resistir a essa pressão. [...] (SANDBERG; COL, 2013, p. 50).

Deste modo, Pereira (2019) afirma que viver com excelência significa pegar o que você tem e fazer o máximo que puder. Compreende-se, então, a extrema importância de posicionamento que as empresas e organizações devem obter em suas diferentes perspectivas sociais, pois é necessária a busca por um espaço cada vez mais igualitário em todos os seus campos de ações diante da sociedade visto que, aderindo à política de igualdade de gênero, estarão contribuindo para decisões mais justas dentro das suas esferas profissionais.

\section{METODOLOGIA}

O objeto de estudo deste artigo consistiu na temática da liderança nas organizações. $\mathrm{O}$ objetivo geral foi identificar, enfatizar e defender a importância da busca de um espaço cada vez mais igualitário em todos os campos de ações das empresas diante da sociedade.

Os objetivos específicos buscaram:

a) Apresentar dificuldades inerentes que o público feminino enfrenta no mercado de trabalho;

b) Analisar causas e condições quanto à desigualdade de gênero;

c) Apresentar propostas de inserção da mulher no mercado de trabalho.

O Campo investigativo deste artigo foi realizado em três diferentes empresas. Uma Empresa Multinacional ${ }^{4}$, localizada no bairro de Prazeres; A Clínica Amor Saúde ${ }^{5}$, localizada no bairro de Piedade; e o Condomínio do Shopping Center Guararapes ${ }^{6}$, localizado em Piedade, todas na cidade de Jaboatão dos Guararapes-PE.

A amostra foi composta por líderes e gestoras das empresas e o instrumento de pesquisa utilizado para coleta de dados de campo foi a aplicação de um questionário semiaberto,

\footnotetext{
${ }^{4}$ Empresa Multinacional dedicada a armazenar, proteger e gerenciar informações e ativos. As soluções incluem a custódia de informações e ativos, gestão de arquivos, e dados e destruição segura. Armazena e protege documentos empresariais, fitas de backup, arquivos eletrônicos, dados médicos entre outros.

5 Clinica Amor Saúde é uma clínica nacional que presta serviços como atendimento médico, odontológico e realiza exames. Levando um atendimento de qualidade e humanizado para os seus pacientes.

6 Condomínio do Shopping Center Guararapes onde contém aproximadamente 200 lojas. Fundado em 1995 foi o segundo shopping inaugurado em Pernambuco. O Shopping Guararapes desenvolve ações de sustentabilidade e educativas, promovendo atividades artísticas, educativas, culturais e capacitação profissional.
} 
conforme ilustrado no Apêndice A. Todos os gráficos constantes da pesquisa são de autoria própria. 


\section{DESENVOLVIMENTO DA PESQUISA DE CAMPO}

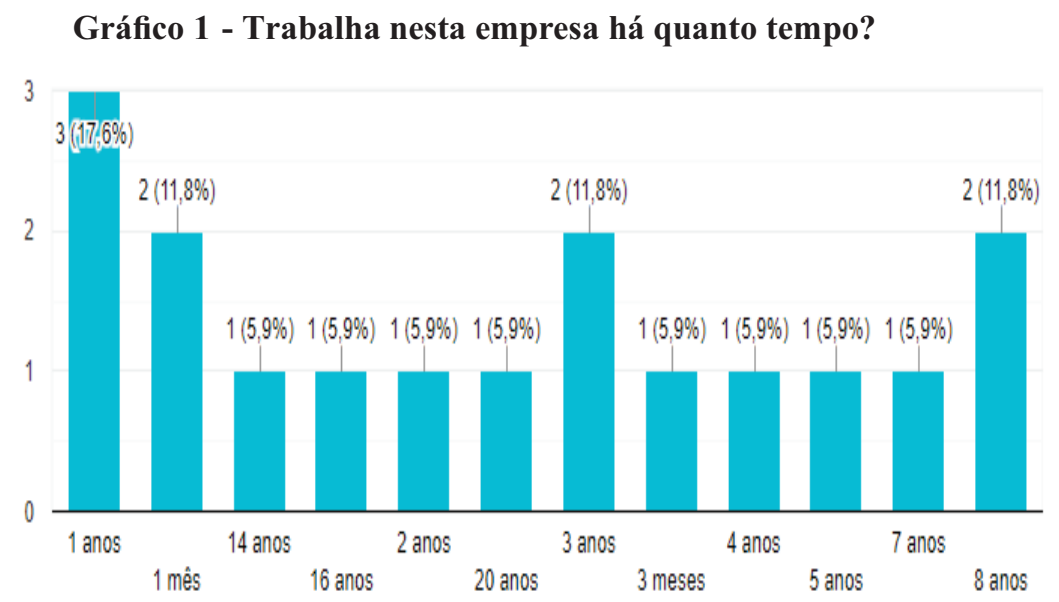

Observa-se neste gráfico que $11,8 \%$ das mulheres trabalham na mesma empresa há 8 anos. Isso demostra a solidez de sua competência, pois a mulher deve ser modelo no seu trabalho, buscando uma organização que lhe ofereça segurança e estabilidade.

\section{Gráfico 2 - Qual a sua idade?}
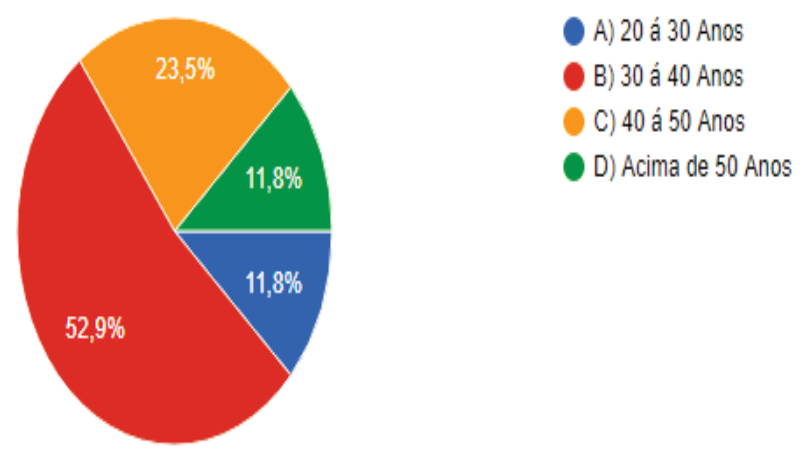

D) Acima de 50 Anos

$52,9 \%$ das mulheres têm entre 30 a 40 anos. Isso mostra o quanto elas têm que percorrer para alcançar um cargo de gestão. Para Ramal (2019) isto ficará no passado, pois a nova geração de mulheres conquistou cargos de gestão mais cedo. Com isso, vemos que as mulheres estão lutando cada dia para obter seu lugar no mais alto escalão. 


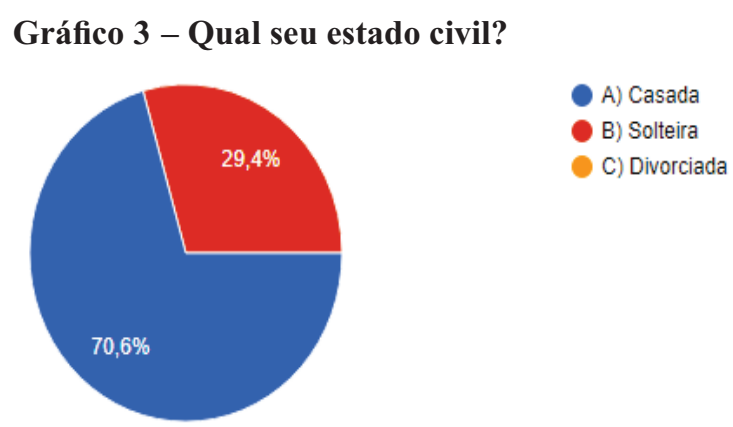

Percebe-se neste gráfico que $70,6 \%$ das mulheres são casadas, provando o que foi citado por Lerner (2020), que nos tempos passados as únicas opções das mulheres eram casar, ter filhos e cuidar da casa. Hoje vemos que as mulheres têm o poder de escolha, se querem apenas casar ou se querem sua vida profissional e seu casamento, não apenas uma única opção.

\section{Gráfico 4 - Você tem filho (s)?}

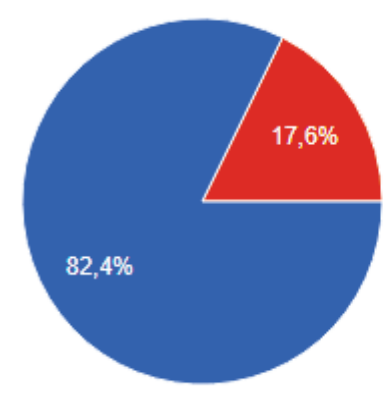

$82,4 \%$ das mulheres líderes possuem filhos. Isto comprova o que foi citado por Lerner (2020), considerando a função materna uma necessidade da espécie, provando que as mulheres acumulam diversas funções trabalhando fora, em casa, e cuidando dos filhos.

\section{Gráfico 5 - Há quanto tempo você exerce cargo de liderança?}

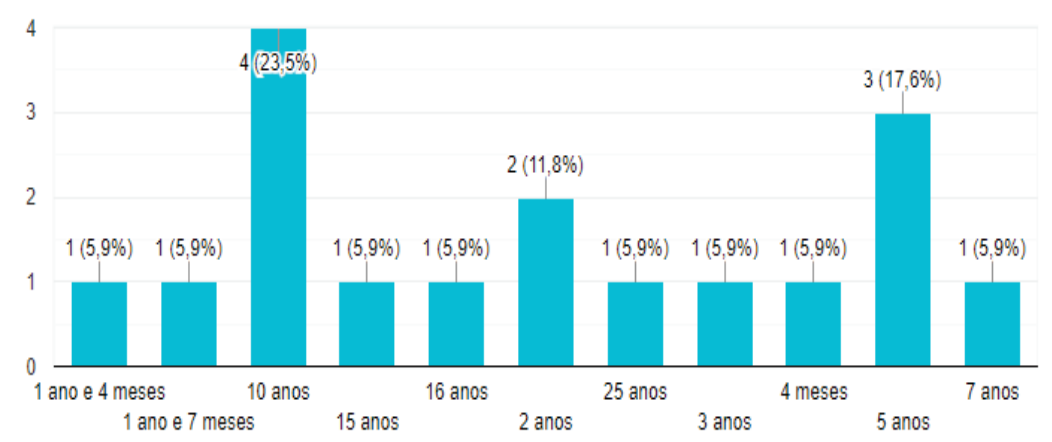

Observa-se neste gráfico que 23,5\% das mulheres exercem cargo de liderança há 10 anos. As mulheres devem assumir cargos de chefia e mostrarem que são competentes como líderes. 


\section{Gráfico 6 - Você é responsável por quantos liderados atu almente?}

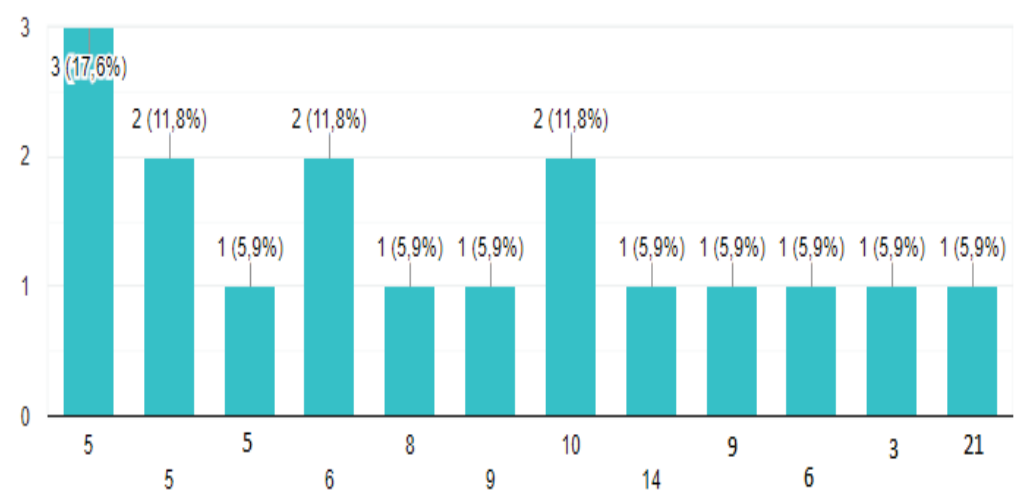

Este gráfico demonstra que a maior parte das mulheres lidera a partir de 5 funcionários. Segundo Scherer (2020), as mulheres vêm liderando de modo único, construindo estratégias e guiando as organizações. Isso prova o quanto as mulheres estão ganhando seu espaço e mostrando que são competentes e capazes de liderar grandes equipes.

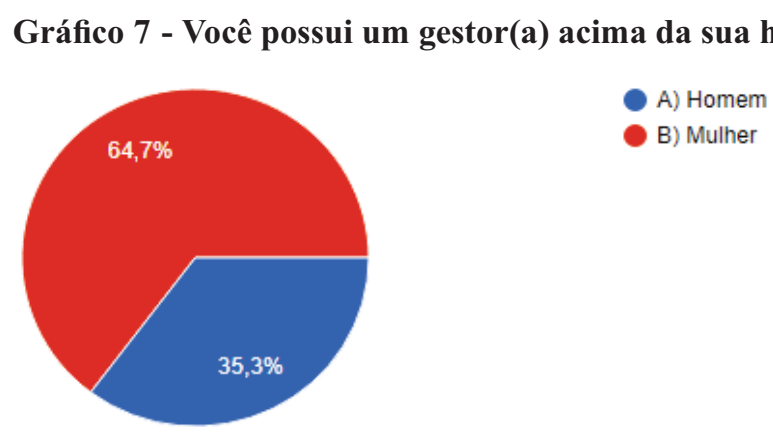

64,7\% das respondentes possuem gestoras mulheres acima de sua hierarquia, assim, mostrando o quão estamos evoluindo no quesito igualdade. Conforme o IBGE (2020), 52\% da população é do gênero feminino, a maioria da população no geral. Sendo assim, deve-se haver igualdade de gênero para ambos os cargos, não privilegiando um ou outro.

\section{Gráfico 8 - Você possui o mesmo estilo de liderança do seu gestor(a)?}

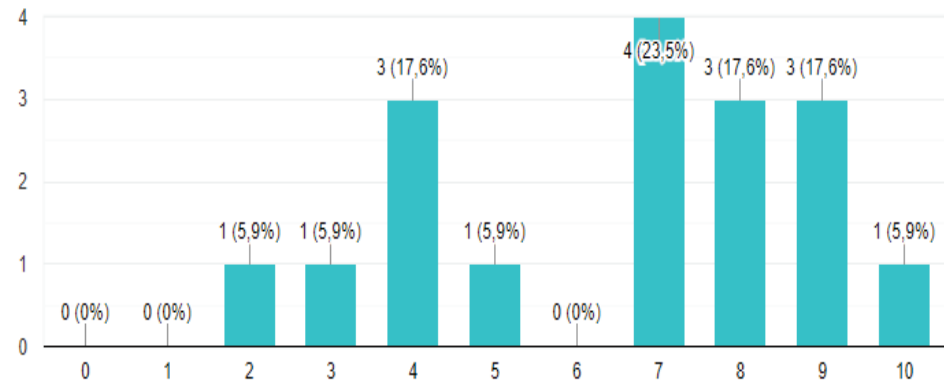


Averiguou-se neste gráfico que $23,5 \%$ das líderes possuem o mesmo estilo de liderança do seu gestor(a). Conforme Sandenberg \& Col (2013), cada pessoa deve mostrar sua própria competência. Assim sendo, cada líder tem sua maneira de liderar.

\section{Gráfico 9 - Qual seu maior desafios/dificuldade profissional na sua função?}

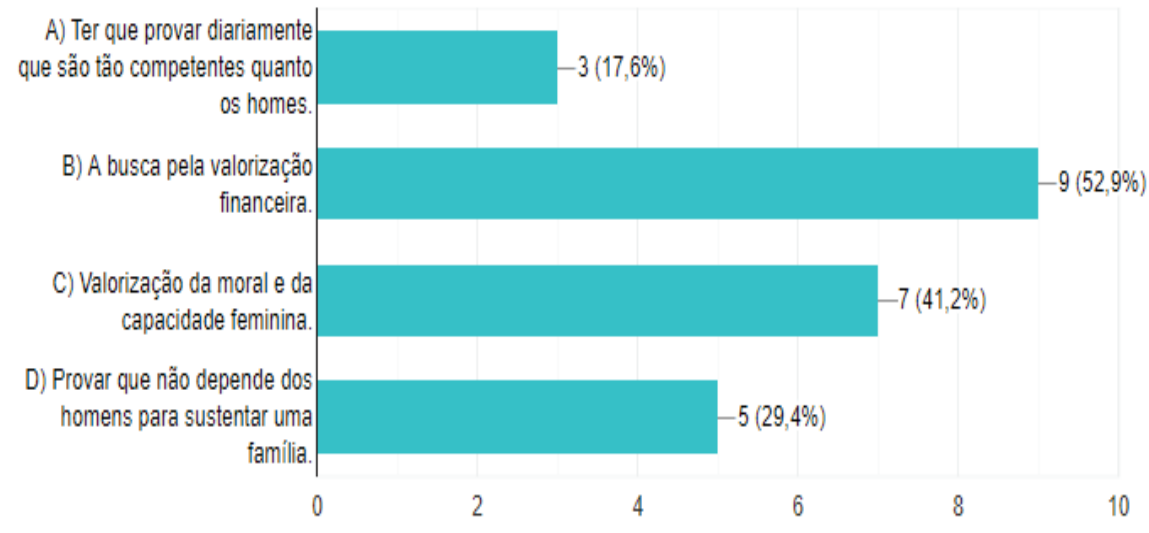

O gráfico mostra que 52,9\% das mulheres acreditam que seu maior desafio/dificuldade profissional é a busca pela valorização financeira. De acordo com Scherer (2020), isso mostra que as mulheres lutam cada dia por reconhecimento financeiro. Portanto, é fundamental a igualdade salarial independente de gênero para quem ocupa o mesmo cargo.

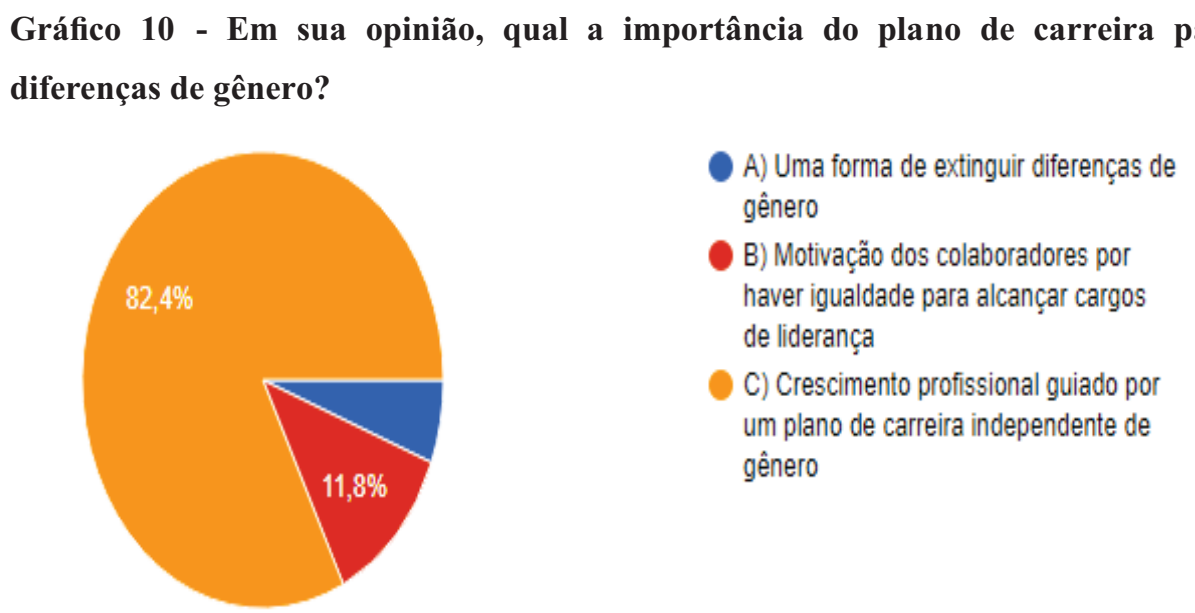

Verificou -se neste gráfico que $82,4 \%$ das mulheres acreditam que essa opção é a mais importante dentro da organização para combater a diferença de gênero. Para Sandberg \&Col (2013) diversidade é fundamental, pois a mulher deve mostrar suas competências sem adotar padrões convencionais. Assim, as organizações devem criar um plano de carreira para o crescimento profissional do funcionário, promovendo vantagens competitivas para ambos os gêneros. 


\section{CONSIDERAÇÕES FINAIS}

O tema é de tal relevância por se tratar de um fator marcante ocorrido na sociedade através da inserção da mulher no mercado de trabalho e da luta para alcançar e conquistar o reconhecimento com a sua participação neste ambiente. O presente projeto defende que é imprescindível a inserção e consolidação absoluta da mulher nas atividades econômicas do mercado de trabalho para que assim encontre uma estruturação e iguale por competência e não por sexo/gênero a ocupação de cargos que sejam os de maiores remunerações ou os de menores remunerações.

Ao concluir o presente artigo é possível se deparar com vários desafios. Nota-se que mesmo se passando anos, décadas e séculos, algumas imagens e comportamentos préconcebidos e generalizados ainda são estabelecidos pelo senso comum da sociedade, insistindo em fincar raízes dentro do mercado de trabalho atual. Isto representa mais luta para as mulheres na busca por seu espaço e reconhecimento de suas habilidades em seu ambiente de trabalho e nas relações e desigualdade de gênero.

Um dos desafios foi apresentar de forma transparente a importância dos valores igualitários em todos os campos de ações, pois o desempenho e a capacidade profissional não possui sexo, gênero, raça ou até mesmo uma nacionalidade.

Ao término deste estudo considera-se que todos os dias mulheres encontram a necessidade em vencer os desafios expostos dentro do mercado de trabalho, mesmo diante da invisibilidade destas, e ainda que preparadas para atuar com êxito.

\section{REFERÊNCIAS}

CARARO, Aryane; SOUZA, Duda. Extraordinárias: mulheres que revolucionaram o Brasil. São Paulo: Editora Seguinte, 2017.

CHIAVENATO, Idalberto. Gestão de Pessoas. São Paulo: Editora Campus Elsevier, 2004.

D’ÁVILA, Manoela. Revolução Laura: reflexões sobre maternidade \& resistência. Rio Grande do Sul: Editora Belas-Letras, 2019.

D’ÁVILA, Manoela. Porque lutamos? São Paulo: Editora Planeta, 2019.

IBGE. Disponível em: https://agenciadenoticias.ibge.gov.br/. Acesso em: 20 set. 2020.

LERNER, Gerda. A criação do patriarcado: história da opressão das mulheres pelos homens. São Paulo: Editora Cultrix, 2020.

PEREIRA, Thalita. Deixe-me apresentar você! São Paulo: Editora Vida, 2019. 
SANDBERG, Sheryl. Faça acontecer: mulheres, trabalho e a vontade de liderar / Sheryl Sandberg com Nell Scovell; tradução Denise Bottmann. São Paulo: Companhia das Letras, 2013.

SCHERER, Louise. Mulheres: gestão, carreira, liderança, desafios e superações. Santa Catarina: Editora Clube de autores, 2020.

SINA, Amalia. Mulher e trabalho: o desafio de conciliar diferentes papéis na sociedade. São Paulo: Editora Saraiva, 2005.

XAVIER, Cristiana. Mulher alfa: liderança que inspira. Minas Gerais: Editora Letramento, 2018.

\section{APÊNDICE A - Questionário utilizado na pesquisa de campo}

O objetivo deste questionário é obter informações referentes à mulher no cargo de liderança e os desafios encontrados em sua posição, além de comparar se há desigualdade entre gêneros dentro da organização a qual faz parte.

1. Trabalha nesta empresa a quanto tempo?

2. Classifique sua idade?

a) 20 a 30 anos.

b) 30 a 40 anos.

c) Acima de 40 anos.

3. Qual seu estado civil?

a) Casada.

b) Solteira.

c) Divorciada.

4. Você possui filhos?

a) $\mathrm{Sim}$.

b) Não.

5. Há quanto tempo exerce o cargo de liderança?

6. Quantos liderados você é responsável atualmente?

7. Quantas pessoas você já liderou nesta empresa?

a) 1 - 10 liderados;

b) 10 - 20 liderados;

c) 20 - 30 liderados;

d) 30 - 40 liderados

e) 40 - 50 liderados

f) Acima de 50 liderados.

8. Você possui um gestor(a) acima da sua hierarquia?

a) Homem

b) Mulher.

9. Você possui o mesmo estilo de liderança do seu gestor(a)?

a) Se sim classifique a semelhança entre 0 a 10

b) Não 
10. Quais seus maiores desafios/dificuldades profissionais na sua função?

a) Ter que provar diariamente que são tão competentes quanto os homes.

b) A busca pela valorização financeira.

c) Valorização da moral e da capacidade feminina.

d) Provar que não depende dos homens para sustentar uma família.

e) Todas as opções anteriores.

f) Outros. Justifique.

11. Quais as diferenças que você percebe quanto a homens e mulheres em cargos de liderança de um modo geral?

a) Diferença salarial;

b) Organização, empatia e sensibilidade;

c) Comunicação, relação interpessoais e percepção em relação ao o que acontece a seu redor.

12. Na sua opinião, qual a importância do plano de carreira para a redução das diferenças de gênero?

a) Uma forma de extinguir diferenças de gênero;

b) Motivação dos colaboradores por haver igualdade para alcançar cargos de liderança;

c) Crescimento profissional guiado por um plano de carreira independente de gênero. 


\title{
MARKETING DE RELACIONAMENTO: UM ESTUDO DE CASO COM CLIENTES E LOJISTAS DO SHOPPING GUARARAPES
}

https://dx.doi.org/10.48097/2674-8673.2022n6p12

\author{
Kamila Miranda ${ }^{1}$ \\ Micheline Farias ${ }^{2}$ \\ Eronildo Carmo ${ }^{3}$
}

\section{RESUMO}

Este artigo tem por objetivo analisar e mostrar a importância do Marketing de Relacionamento para as organizações, as consequências, fidelização e conservação de clientes. Trata-se de uma pesquisa de natureza exploratória, de abordagem direta, por uma busca qualitativa, nas ações do Marketing de Relacionamento voltado para o cliente. A investigação se deu por meio da pesquisa de livros e artigos especializados. Para coleta e análise dos dados foi utilizado um formulário estruturado por meio de entrevistas com gestores, proprietários de lojas e clientes do Shopping Guararapes. Foi possível chegar a conclusão sobre a importância de aprimorar o Marketing de Relacionamento por parte das empresas, com o uso de um planejamento do seu produto, fazendo mais uso de estratégias voltadas para o perfil do público alvo.

Palavras-chave: Cliente. Fidelização. Marketing de Relacionamento.

Data de submissão: 06/08/2021

Data de aprovação: 09/09/2021

\begin{abstract}
This study aims to analyze and show the importance of Relationship Marketing for organizations, the consequences, loyalty and retention of customers. This is an exploratory research, with a direct approach, through a qualitative search, in the actions of Relationship Marketing aimed at the customer. The investigation was carried out through the search of specialized books and articles. For data collection and analysis, a structured form was used through interviews with managers, store owners and customers at Shopping Guararapes. It was possible to reach a conclusion about the importance of improving the Relationship Marketing by the companies, with the use of planning for its product, making more use of strategies aimed at the profile of the target audience.

\footnotetext{
${ }^{1}$ Discente do Curso Tecnológico de Marketing da Faculdade Metropolitana da Grande Recife.

E-mail: krpmiranda2019@gmail.com

${ }^{2}$ Discente do Curso Tecnológico de Marketing da Faculdade Metropolitana da Grande Recife.

E-mail: michelinefarias.1998@gmail.com

${ }^{3}$ Orientador / Docente da Faculdade Metropolitana da Grande Recife.

E-mail: proferon100@gmail.com
} 
Keywords: Customer. Loyalty. Marketing of relationship.

\section{INTRODUÇÃO}

As empresas, atualmente, enfrentam uma competição acirrada, sendo que os clientes podem optar por uma ou outra organização disponível no mercado para suprir suas necessidades. Desta forma, as organizações estão procurando diversas maneiras possíveis de proporcionar o que os clientes desejam e necessitam na intenção de fidelizá-los. Para lidar com esta situação os estabelecimentos comerciais precisam entender não apenas quem são os seus consumidores, mas também utilizar o marketing de relacionamento que tem como direção a identificação dos benefícios que devem ser ofertados e conhecer seu público alvo para lhes ofertar produtos e serviços que venham atender seus requisitos de compra e possa, por meio desse relacionamento, reter e personalizar o público desejado.

\section{REFERENCIAL TEÓRICO}

O marketing de relacionamento é essencial ao desenvolvimento da liderança no mercado, da criação de relações sólidas entre empresa e cliente, e sua manutenção por longo tempo. Essa situação tem sido tarefa árdua e de difícil manutenção em um mercado onde os clientes têm uma infinidade de opções na aquisição de produtos e serviços, bem como fornecedores, ofertando produtos semelhantes e às vezes substitutos, tornando-se difícil manter uma relação pessoal que é uma das formas de conquistar a fidelização do cliente.

De acordo com Kotler (2000), a manutenção dos clientes atuais e potenciais para a empresa torna-se de importância considerável. O autor ainda destaca que elas devem desenvolver cada vez mais relacionamento estreito, de modo a caminhar para a fidelização e que ele se torne lucrativo para a empresa. Desse modo, o marketing de relacionamento vem sendo priorizado como uma das principais ferramentas para a tomada de decisão nas diferentes organizações no que concerne a retenção e a fidelização de seus clientes.

\section{O Futuro do Marketing}

De acordo com Kotler e Armstrong (2004), o objetivo tradicional sempre foi a atração de novos clientes e não a retenção dos existentes. Segundo os autores, marketing é a análise, organização, planejamento e controle dos recursos da empresa, gerados a partir do consumidor, com o objetivo de satisfazer suas necessidades e desejos, de forma lucrativa.

Muitas pessoas pensam em marketing apenas como venda e propaganda, porém sua função é satisfazer as necessidades dos clientes. Conforme Sobral e Peci (2008), o marketing 
é um processo administrativo pelo qual indivíduos e organizações obtêm o que necessitam por meio de criação de troca de valor com os clientes para atingir os objetivos organizacionais. $\mathrm{O}$ marketing possui três grandes eixos de ação:

1) O foco na satisfação do cliente;

2) A integração de todas as atividades da organização na satisfação do cliente;

3) A realização dos objetivos da organização (consequência da satisfação dos clientes).

Com a competição por cliente cada vez mais acirrada, a venda deve ser vista como o início de um relacionamento e não como um ponto final de uma negociação. Através desse relacionamento é possível uma manutenção do cliente e, consequentemente, a certeza de futuras vendas. De acordo com Barreto \& Crecitelli (2008), um cliente só se manterá fiel se notar algum beneficio por parte da empresa.

O marketing está presente em nossas vidas todos os dias e em todos os lugares. Em uma caminhada, na TV, quando abrim os o jornal, em uma busca no Google. Difícil traduzir o que de fato significa, em poucas palavras. Marketing é uma atividade, um conjunto de instituições e processos para criar, comunicar, entregar e oferecer trocas com valor para os consumidores, clientes, parceiros e sociedade em geral.

\section{As Perspectivas e Expectativas dos Clientes}

Durante um relacionamento com uma determinada empresa, o consumidor pode distinguir e julgar entre os episódios de contato mais e menos importantes. Uma boa gestão de relacionamento é crucial em certos instantes, uma vez que é fundamental contactar o cliente sempre que ele estiver necessitando contratar um serviço/produto ou ter um retorno do serviço/produto adquirido. Essas atitudes evitarão situações desagradáveis como deixar o cliente esperando sem necessidade, por exemplo. Esse tipo de episódio de contato é julgado como um dos mais importantes para os consumidores.

As perspectivas de relacionamento dos clientes dependem do que eles consideram importantes. Oferecer produtos e serviços que satisfaçam exige conhecimento das expectativas dos clientes. Esses programas ajudam as empresas a priorizar as expectativas, detectar as mudanças de importância dessas expectativas e conhecer o valor das necessidades existentes. (VAVRA, 1993; BOGMANN, 2002).

Para compreender o processo de formação da satisfação, devemos considerar a existência de dois fatores determinantes da satisfação do consumidor propostos por Anderson, Fornell e Lehmann (1994), que são: 
1. Qualidade percebida: diz respeito à avaliação atual do desempenho da empresa, que influi positivamente na satisfação total do cliente em relação ao produto ou serviço. A qualidade percebida é avaliada através do grau de customização da oferta da empresa em relação às necessidades do cliente, e da credibilidade dessa oferta em sua consistência. A qualidade percebida confere uma medida para a avaliação do consumidor sobre a superioridade ou excelência de um produto ou serviço;

2. Expectativas: refere-se ao conhecimento prévio sobre a qualidade das ofertas de um fornecedor, ou seja, a partir das suas experiências anteriores, os consumidores formam suas expectativas, que também são desenvolvidas baseadas na qualidade atual e servem de críticas para sua satisfação. Neste contexto, podemos afirmar que o processo de formação da satisfação do consumidor está relacionado com o desempenho por este esperado, e as expectativas iniciais, existentes antes mesmo da compra. Se o desempenho atende às expectativas, o resultado é a satisfação; se não atende, a insatisfação.

Segundo Kotler (2001), as expectativas são influenciadas por uma experiência anterior de compra, por recomendações de amigos e colegas, ou por informações e promessas das empresas e dos concorrentes. Antes da aquisição de um produto ou serviço, os consumidores criam expectativas em relação a eles, que, após a compra ou o uso, serão comparadas ao desempenho real, onde essas expectativas poderão ser confirmadas ou não.

O resultado dessa comparação pode se apresentar de três formas distintas: desconfirmação negativa, quando o produto ou serviço é pior do que o esperado; desconfirmação positiva, quando é melhor do que o esperado; e desconfirmação zero, quando simplesmente ocorre o esperado. (OLIVER MIRANDA, 2001, p. 26).

Dessa forma, fica clara a relação existente entre a satisfação do cliente com as suas expectativas e o desempenho da empresa, através dos seus produtos ou serviços. Se o desempenho alcançar as expectativas, o cliente ficará satisfeito. Se o desempenho for além das suas expectativas, ou seja, se excedê-las, o cliente ficará altamente satisfeito ou encantado. Em contrapartida, se o desempenho não alcançar as expectativas, o cliente ficará insatisfeito. (KOTLER e KELLER, 2006).

Dessa forma, pode-se dizer que a satisfação do consumidor é o ponto chave para a retenção de clientes, pois, quanto mais satisfeito estiver o cliente, maior a probabilidade deste se tornar fiel. 


\section{Técnicas e Programas de Fidelização}

O conceito desses programas envolve uma troca: a empresa oferece vantagens e benefícios a quem dá preferência a seus produtos e serviços. (BOGMANN,2002). Um programa de fidelização implica no uso de várias ferramentas promocionais, mas não deve ser confundido com elas. Eles são ações contínuas e que recompensam os clientes fiéis, diferentemente de promoções de vendas que visam compras e recompras, com prazo determinado, sem o processo de fidelizar. Em um programa de fidelização, a base reside nas informações e conhecimentos sobre os clientes que geralmente ficam armazenados em bancos de dados, mas não é toda empresa que comporta esse tipo de estratégia devido ao custo elevado, com isso, a empresa deve agir de acordo com a sua receita e beneficiar os melhores clientes potenciais. Com esses dados a empresa pode criar ações de comunicação direcionadas para grupos de clientes, conforme suas expectativas.

Para Bogmann (2002), fidelizar é transformar um comprador eventual em um comprador frequente. É fazer com que esse cliente compre cada vez mais e até divulgue a empresa. Portanto, para construir um programa de fidelização é essencial entender as necessidades, desejos e valores dos clientes, para depois traçar uma estratégia adequada de fidelização, sabendo que a abordagem mais adequada consiste não apenas falar com o cliente, mas também ouvi-lo, ou seja, um relacionamento de duas vias. Afinal, o custo de aquisição de novos consumidores é sempre maior do que o custo de manutenção dos clientes atuais.

O Marketing de Relacionamento não defende a aplicação de toda a verba promocional com os clientes atuais, mas na verdade questiona a distribuição atual do gasto entre aquisição e manutenção de clientes. Geralmente a quantia gasta com aquisição é muito superior, e este pode não ser o balanço que leva ao melhor retomo.

\section{METODOLOGIA}

O objetivo desse artigo é identificar e analisar o Marketing de Relacionamento, suas consequências e sua importância diante das expectativas dos clientes, a fidelização e os meios para atingir tal objetivo.

Esta pesquisa caracteriza-se como bibliográfica, aplicada, propositiva e com abordagem qualitativa e quantitativa. $O$ universo e amostra a serem investigados são os gestores ou proprietários e clientes das lojas do Shopping Guararapes ${ }^{4}$. O instrumento de

\footnotetext{
${ }^{4}$ O Shopping Guararapes está localizado em Piedade, Jaboatão dos Guararapes, na Rua Barreto de Meneses 800 , com 200 lojas com mais de 30 segmentos diferentes. O Shopping tem um fluxo diário de aproximadamente 47 mil pessoas que resulta em mais de 16 milhões de consumidores a cada ano.
} 
pesquisa constou de entrevista estruturada e questionários semiabertos, um para o gestor ou proprietário da empresa entrevistada e o outro para os clientes. A Pesquisa foi realizada pela plataforma digital do Google Forms, durante o mês de junho de 2021, e contou com a participação de 90 clientes e 76 lojistas.

\section{DESENVOLVIMENTO E RESULTADO DA PESQUISA DE CAMPO}

A seguir são mostrados os gráficos referentes aos resultados obtidos por intermédio dos questionários aplicados aos clientes e aos lojistas.

\section{Resultados do questionário aplicado aos clientes do Shopping Guararapes}

Gráfico 1 - Participação em campanhas

Você participa das campanhas de fidelizações das lojas que você é cliente?

90 respostas

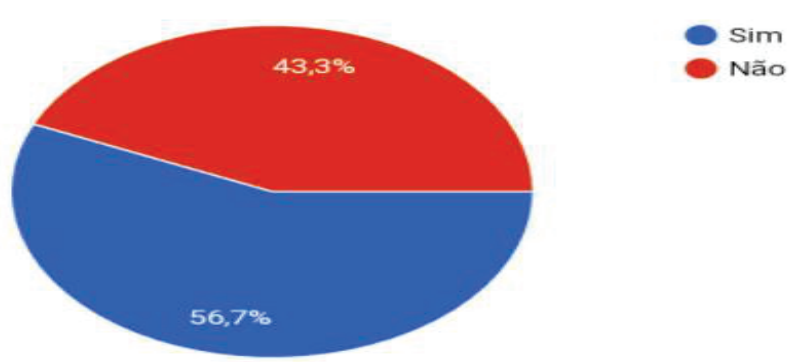

Fonte: os autores

O gráfico 1 mostra que 56,7\% dos clientes entrevistados participam de campanhas de fidelizações das lojas, contra 43,3 dos que não participam. 
Gráfico 2 - Decisão de compra

Como você toma sua decisão de compra? 90 respostas

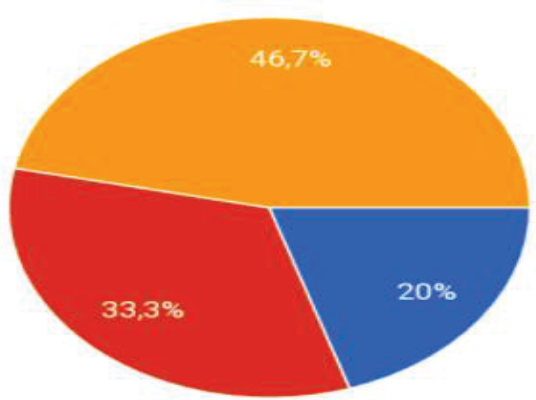

Atendimento

Preço

Qualidade

Fonte: os autores

No gráfico 2 observamos que 46,7\% dos clientes entrevistados tomam sua decisão pela qualidade do produto, $33 \%$ pelo preço, e $20 \%$ pelo atendimento.

Gráfico 3 - Indicação de produtos e serviços

que te faz Indicar Produtos ou serviços?

90 respostas

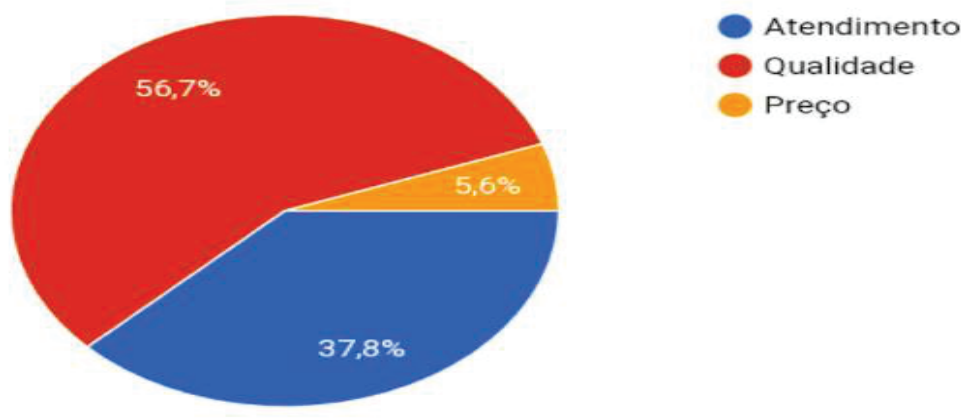

Fonte: os autores

O gráfico 3 descreve que 56,7\% dos clientes indicam produtos ou serviços pela qualidade; 37,8\% indicam produtos ou serviços pelo atendimento; e 5,6\% pelo preço. 


\section{Gráfico 4 - Retorno à loja}

O que te faz voltar a mesma loja?

90 respostas

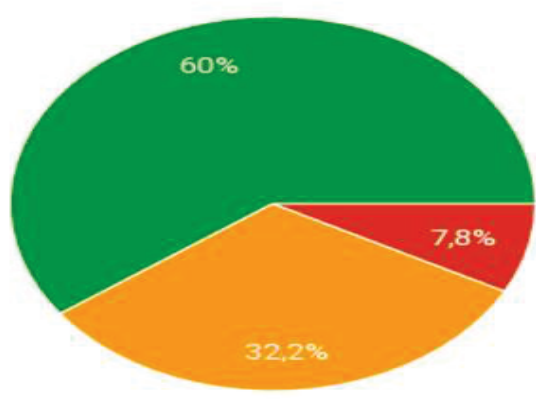

Arrumação da Loja

Produto

Qualidade

Atendimento

Fonte: os autores

O gráfico 4 mostra que $60 \%$ dos clientes entrevistados informaram que o atendimento o faz voltar à loja; $32,2 \%$ retornam pela qualidade do produto ou serviços; e 7,8\% pelo produto oferecido.

Gráfico 5 - Pagar mais caro por um bom atendimento

Como cliente, você está disposta (o), a pagar mais caro, por ter um bom atendimento ?

90 respostas

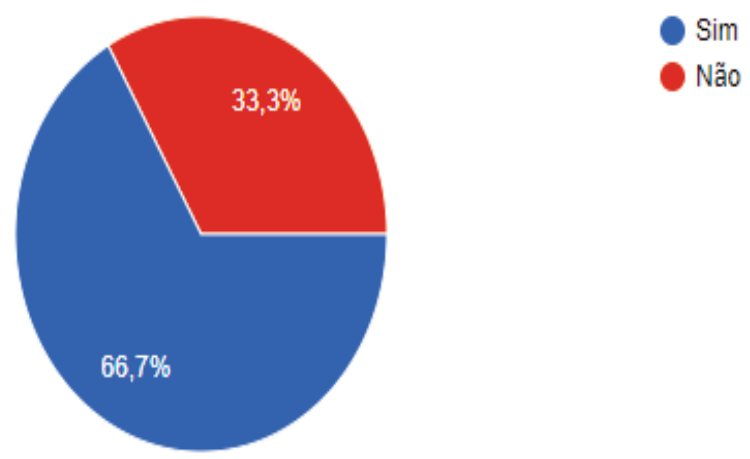

Fonte: os autores

No gráfico 5 constatamos que $66,7 \%$ dos clientes estão disposto a pagar mais caro por um bom atendimento, enquanto 33,3\% afirmam o contrário. 
Gráfico 6 - Satisfação com o atendimento digital

Como você se sente com o atendimento digital?

90 respostas

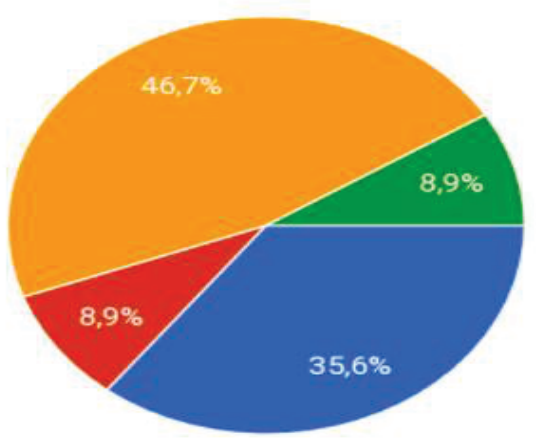

Satisfeito

Totalmente satisfeito

- As vezes satisfeito

Não gosto

Fonte: os autores

O gráfico 6 mostra que 46,7\% dos entrevistados às vezes se sentem satisfeitos com o atendimento digital; $35,6 \%$ sentem-se satisfeitos; $8,9 \%$ dizem estar totalmente satisfeitos; e $8,9 \%$ não gostam do atendimento digital.

\section{Resultados do questionário com gestores/proprietários das lojas}

Gráfico 7 - programa de fidelização

A empresa possui programa de fidelização para os seus clientes?

76 respostas

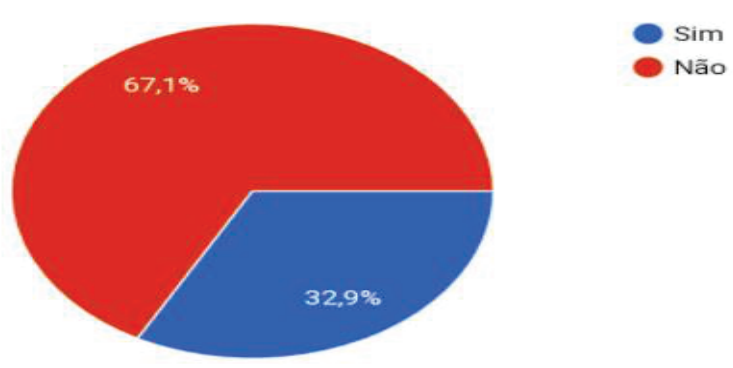

Fonte: os autores

Observamos no gráfico 7 que $67,1 \%$ dos lojistas afirmam que sua loja não possui um programa de fidelização, enquanto 32,9 afirmam possui-lo. 
Gráfico 8 - Pós-venda

Na empresa existe o Pós-Venda?

76 respostas

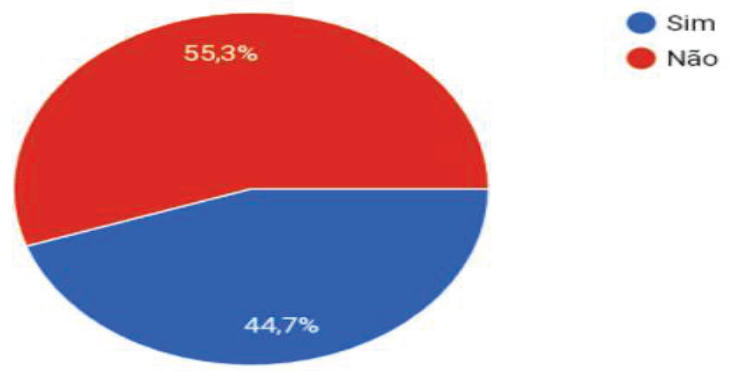

Fonte: os autores

Neste gráfico 8 observamos que 55,3\% das lojas entrevistadas trabalham com pós-venda contra 44,7 dos que não adotam esse sistema.

Gráfico 9 - Perfil do cliente

Qual o perfil do seu cliente?

76 respostas

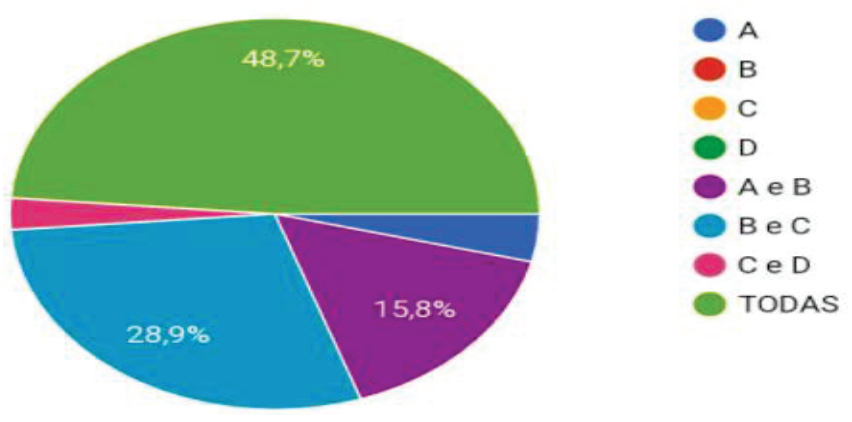

Fonte: os autores

O gráfico 9 mostra que as lojas trabalham voltadas ao atendimento de clientes de todas as classes. 


\section{Gráfico 10 - Clientes desertores}

A empresa tem ações ou programas apara retornar clientes que desertaram ? (o abandono )

76 respostas
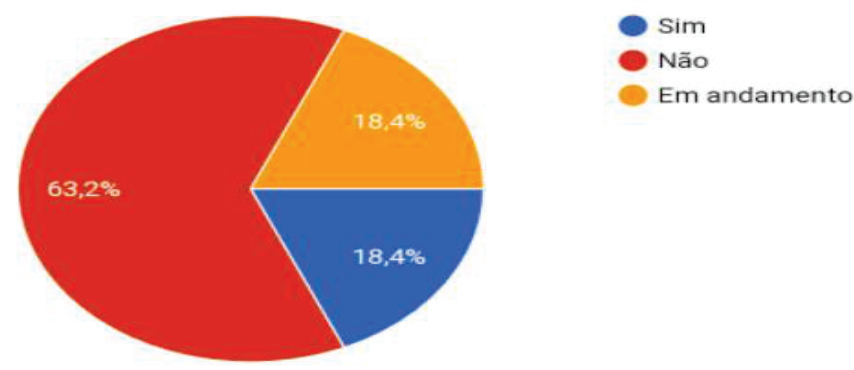

Fonte: os autores

O gráfico 10 deixa claro que a grande maioria das lojas não possui um programa que acompanhe os clientes desertores.

Gráfico 11 - Canais de verificação de insatisfação

Qual o canal utilizado para verificar a insatisfação do cliente, usado pela empresa?

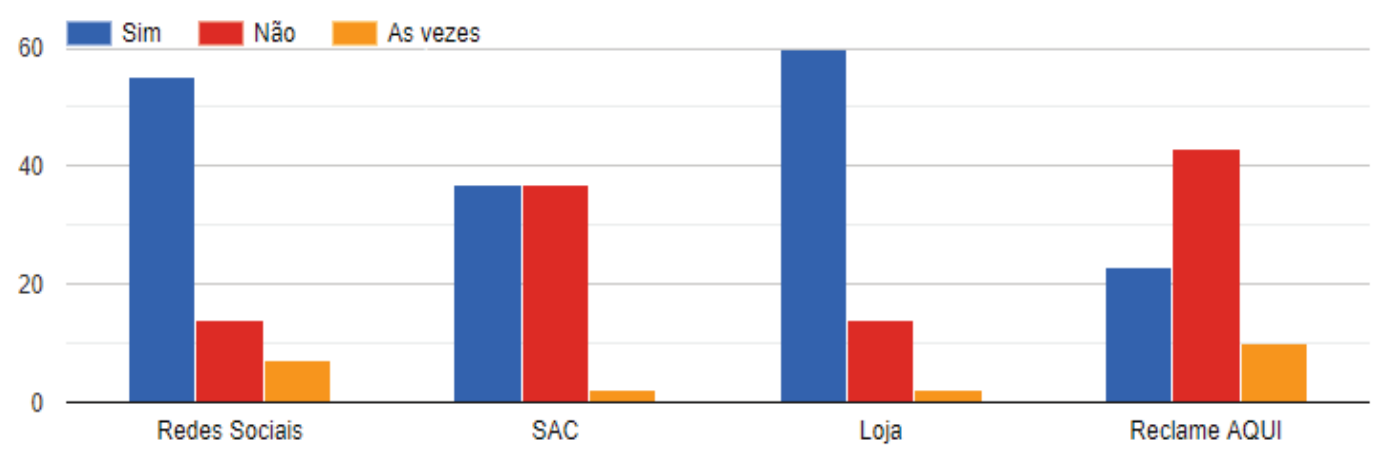

No gráfico 11 entendemos que o canal mais usado pelas organizações para verificar a insatisfação dos clientes é a própria loja (60\%), enquanto 55\% citaram as redes sociais. Com a Pandemia todas as organizações entrevistadas tiveram que se adaptar às redes sociais e plataformas digitais para sua comunicação com o cliente e verificação das suas insatisfações. 


\section{CONSIDERAÇÕES FINAIS}

Devido ao atual período de Pandemia da Covid-19, foi provocado uma mudança de comportamento na relação empresa e consumidor não apenas nas lojas do Shopping Guararapes. As mudanças de hábitos trouxeram a necessidade de se reinventar, através das vendas pelas plataformas digitais e por WhatsApp, desde as pequenas até as grandes empresas.

Foi possível chegar a conclusão sobre a importância de aprimorar o Marketing de Relacionamento por parte das empresas, com o uso de um planejamento do seu produto, fazendo mais uso de estratégias voltadas para o perfil do público alvo.

Em época de acirrada concorrência boa parte dos lojistas entrevistados não trabalha com o sistema de pós-venda e não oferece programas de recompensas ou fidelização aos seus clientes. Fica a sugestão para que estes reavaliem suas atividades, buscando no Marketing de Relacionamento uma ferramenta para alavancar as vendas e a fidelização de sua clientela.

\section{REFERÊNCIAS}

ANDERSON, E. W.; FORNELL, C.; LEHMANN, D. R. 1992. Satisfação do cliente, Market Share e lucratividade. Journal of Marketing, Suécia, vol. 58, jul. 1994.

BARRETO, I. F.; CRESCITELLI, E. O futuro do marketing de relacionamento. ESPM, v. 15, n. 4, p. 96 - 101, jul - ago, 2008.

BOGMANN, I. M. Marketing de relacionamento: estratégias de fidelização e suas implicações financeiras. São Paulo: Futura, 2002.

KOTLER, P. Administração de marketing. 5. ed. São Paulo: Atlas, 2000.

KOTLER, P.; KELLER, L. K. Administração de marketing. 12. ed. São Paulo: Atlas, 2006.

KOTler, P.; ARMSTrOng, G. Princípios de marketing. 9. ed. São Paulo: Pearson Prentice Hall, 2004. 
MIRANDA, Oliver. Uma análise crítica dos ideários pedagógicos contemporâneos. Novo paradigma de conhecimentos e políticas educacionais na América Latina. Cad. Pesq., n. 100, p. 37-48, mar. 1997.

SOBRAL, F.; PECI, A. Marketing: teoria e prática do contexto do marketing. 2. ed. São Paulo: Pearson Education do Brasil, 2008.

VAVRA, T. G. Marketing de relacionamento: como manter a fidelidade de clientes através do marketing de relacionamento. São Paulo: Atlas, 1993.

\section{APÊNDICE A - Formulário de Entrevista (Gestor ou Proprietário)}

1) Quais os canais de comunicação que a empresa utiliza para se comunicar com seus clientes externos?

2) Existe uma comunicação diferenciada de acordo com o perfil do cliente? $\operatorname{Sim}($ ) Não ( )

3) Os colaboradores são treinados para efetuar uma comunicação adequada aos clientes? Sim ( ) Não ( ) Às vezes ( ) Quase nunca ( )

4) A empresa investe em tecnologia da informação para manter um bom relacionamento com os clientes? Sim ( ) Não ( ) Em andamento ( )

5) A empresa procura se aproximar de seus clientes dedicando tempo para conhecer suas necessidades? Sim ( ) Não ( )

6) A empresa faz pesquisas para avaliar a satisfação dos clientes? Sim ( ) Não ( )

7) A empresa possui um programa de fidelização para seus clientes? Sim ( ) Não ( ) Como é feito?

8) A empresa toma conhecimento dos clientes que desertam?

Sempre ( ) Às vezes ( ) Nunca ( )

9) A empresa conhece os motivos da deserção de clientes? Sim ( ) Não ( ) Geralmente quais são?

10) A empresa tem ações ou programas para retornar clientes que desertaram?

$$
\text { ( ) Sim ( ) Não }
$$

11) Qual a classe social do perfil do seu cliente?

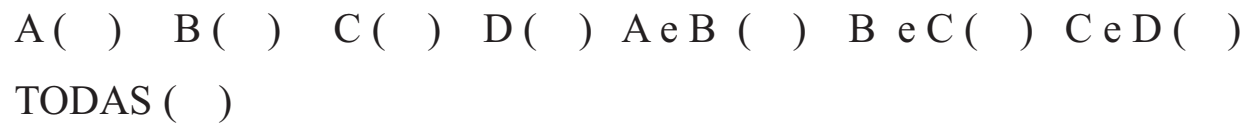

12) A empresa proporciona benefícios que provocam a procura de produtos e serviços? 
Sempre ( ) As vezes ( ) Nunca ( ) Quase Nunca ( )

13) Na empresa existe o pós-venda? Sim ( ） Não ( )

\section{APÊNDICE B - Formulário de Pesquisa (Clientes)}

1) Você participa das campanhas de fidelização das lojas em que você é cliente ?

$$
\operatorname{Sim}(\quad) \text { Não ( ) }
$$

2) Ao entrar na loja você gosta de :

( ) Ser acompanhado

( ) Fazer o autoatendimento

( ) Às vezes busco ajuda

3) Como você toma sua decisão de compra?

Atendimento ( ) Preço ( ) Qualidade ( )

4) O que te faz voltar à mesma loja ?

Arrumação da loja ( ) Produto ( ) Qualidade ( ) Atendimento ( )

5) Você já foi mau atendido em algum atendimento ?

$$
\text { ( ) Sim ( ) Não Como se sentiu? }
$$

6) O que te faz indicar produtos ou serviços? Atendimento ( ) Qualidade ( ) Preço ( )

7) Quais as consequências que as campanhas das lojas causam em você? Comprar mais ( ) Ignorar campanha ( ) Voltar na loja assim que tiver oportuni dade ( )

8) Indique uma loja que seja uma referência em atendimento pra você? Porque?

9) Como se sente ao receber e-mail, mensagens, telefonemas, dando os parabéns pelo seu aniversário, novas coleções e promoções?

Gosto muito ( ) Gosto ( ) Às vezes ( ) Indiferente ( ) Não gosto ( ) 10) $O$ que te chateia em um atendimento? Marque um $x$ até três opções:
( ) Tempo de espera
( ) Troca
( ) Mau atendimento
( ) Retorno de Resposta
( ) Produto sem Qualidade
( )Atraso
( ) Resolver por telefone
( ) Resolver Presencial
( ) Resolver Online
( ) Não ser chamado(a) pelo nome 
11) O que você gosta em um atendimento? Marque um $x$ até três opções:

( ) Agilidade

( ) Exclusividade

( ) Atendimento

Personalizado

( ) Resposta objetiva

( ) Produto de Qualidade ( ) Ouvir minhas necessidades

( ) Resolver por telefone

( ) Resolver Presencial

( ) Resolver Online

( ) Ser chamada pelo nome

12) Com relação ao atendimento digital, você se sente bem atendido(a)?

Satisfeito ( ) Totalmente satisfeito ( ) As vezes satisfeito ( ) Não gosto ( )

13) Você se considera um cliente:

( ) Fiel ( ) Que busca preço ( ) Que busca qualidade ( ) Que busca promoção 


\title{
MUDANÇAS ORGANIZACIONAIS: IMPACTOS E REAÇÕES JUNTO AO CORPO FUNCIONAL DE UMA ESCOLA DE ENSINO INFANTIL
}

\author{
https://dx.doi.org/10.48097/2674-8673.2022n6p13
}

\author{
Arandi Maciel Campelo ${ }^{1}$ \\ Huggo Matheus Oliveira Nunes do Nascimento ${ }^{2}$
}

\section{RESUMO}

Este artigo tem por finalidade abordar conceitos sobre processo de mudança organizacional, métodos e estratégias utilizadas dentro de uma escola de ensino infantil, e conseguir superar todas as turbulências envolvidas no processo, além de identificar os principais problemas que ocorrem e seus motivos e formas de como solucionar essa problemática, além dos meios corretos de realizar as mudanças necessárias, ressaltando os medos de colaboradores e a função dos gestores nesse processo, apresentando, assim, planos e comportamentos para realizar mudanças organizacionais, para o melhor funcionamento de grandes e pequenas empresas e evitar as problemáticas encontradas no processo. O levantamento e análise da pesquisa campo foram realizados através de um questionário semiaberto aplicado entre 24/06/2021 e 02/05/2021, com 13 colaboradores, correspondendo a 100\% do universo considerado. A pesquisa demonstrou o quão significante é a visão dos colaboradores e gestores, pois é fundamental um bom relacionamento para se ter uma resolução no processo de mudança organizacional.

Palavras-chave: Mudanças organizacionais. Impactos e reações às mudanças organizacionais. Clima organizacional.

Data de submissão: $16 / 08 / 2021$

Data de aprovação: 21/09/2021

\begin{abstract}
The main purpose of this article is to address concepts about the process of organizational change, methods and strategies used within a kindergarten school, and to be able to overcome all the turbulences involved in the process, in addition to identifying the main problems that occur and their reasons and forms how to solve this problem and the correct means and make

1 Orientador: Doutor em Educação - Universidade Federal de Pernambuco; Administrador - Universidade de Pernambuco - FCAP/UPE; Mestre em Planificación y Gestion Organizacional - Universidad Autonoma de Madrid / Espanha; Mestre em Dirección y Organización de Hospitales y Servicios de Salud - Universidad Politécnica de Valencia / Espanha; Especialista em Marketing - FCAP/UPE; Consultor em Sistemas Organizacionais, desde 1984; Professor e Diretor Acadêmico da Faculdade Metropolitana da Grande Recife. E-mail: arandi.campelo@globo.com

2 Estudante do curso de Administração da Faculdade Metropolitana da Grande Recife.

E-mail: huggomatheus2000@gmail.com
\end{abstract}


the necessary changes, highlighting the fears of employees and the role of managers in this process, thus presenting plans and behaviors to carry out organizational changes, for the better functioning of large and small companies and avoid the problems found in the process. The survey and analysis of the field research were carried out through a semi-open questionnaire applied between $06 / 24 / 2021$ and $05 / 02 / 2021$, with 13 collaborators, corresponding to $100 \%$ of the considered universe. The survey showed how significant is the vision of employees and managers because a good relationship is essential to have a resolution in the process of organizational change.

Keywords: Organizational changes. Impacts and reactions to organizational changes. Organizational climate.

\section{INTRODUÇÃO}

Este artigo tem por tema as mudanças organizacionais e seus desafios. Ele aborda os medos dos colaboradores quando se deparam com as mudanças, quais são os desafios dos gestores quando precisam realizar essas alterações (tanto por necessidade ou para melhoria), e como a empresa pode diminuir as crises e possíveis boicotes. Há a necessidade de estratégias para que quando as mudanças forem propostas e implementadas não venham a causar transtornos, gastos desnecessários, maior tempo de implementação das propostas a serem colocadas em prática. A mudança deve conter uma proposta benéfica e que traga o objetivo pretendido para todos os envolvidos no processo de mudança organizacional.

\section{REFERENCIAL TEÓRICO}

Nesta seção são abordados conteúdos sobre as mudanças que ocorrem na organização, e os seus principais problemas que envolvem a implantação dessas mudanças, dando visão para os colaboradores e para a organização, observando quais impactos que estes processos ocasionam. São abordados três elementos: primeiramente, os medos que os colaboradores possuem; segundo, os desafios que a organização possui para programar as mudanças; e por fim quais os principais elementos para a mudança ser realizada com êxito.

\section{Medos das mudanças na organização}

As mudanças dentro de uma organização se fazem necessárias para melhoria de processos e, consequentemente, trazendo melhores resultados para a empresa. Entretanto, mudanças em procedimentos, processos, lideranças, atividades, trazem medo aos colaboradores, sobretudo em pequenas empresas. Segundo Marques (2011):

Quando uma mudança é proposta no ambiente de trabalho quase sempre gera uma percepção de ameaça ao status quo ${ }^{3}$ do indivíduo, que se encontra fundamentalmente

3 Status quo = permanência do estado das coisas, ou seja, continuar da forma em que se encontra. 
organizado e seguro. Esse tipo de acontecimento provoca um desequilíbrio interno, que desencadeia reações imediatas. (MARQUES, 2011, p.7).

De acordo com o autor, quando as mudanças são sugeridas trazem uma ameaça àqueles que estão diretamente envolvidos nas alterações. Por estar afetando a sua percepção de estabilidade na sua atividade, e por uma questão de preservação, são geradas reações imediatas para ter aquele estado de segurança novamente. Quando o colaborador se sente ameaçado com a mudança vai procurar se preservar, podendo gerar um prejuízo à organização, tomando atitudes para mostrar aos líderes que não é uma boa ideia fazer as mudanças, simplesmente optando pela preservação do seu cargo.

As mudanças dentro das organizações se fazem necessárias para melhorar processos e diminuir os custos. Sendo assim, as lideranças devem comunicar e explicar aos funcionários o porquê da mudança, como ela ocorrerá, e em algumas situações escutar os colaboradores para conseguir um consenso para que os possíveis problemas gerados por causa das mudanças sejam diminuídos. Conforme cita Fonseca (2000):

\footnotetext{
Mesmo quando as mudanças são necessárias, o receio dos envolvidos na mudança gera grandes impactos, e dificilmente são recebidos de forma consensual, mudanças na organização sendo culturais, tecnológicas, processo e liderança sendo feita de forma inadequada sempre ocorre resistência, ressentimentos e até despoletar ${ }^{4}$ a implementação da proposta. (FONSECA, 2000, p. 3).
}

Quando iniciamos o processo de entendimento do conceito de mudanças e os medos que elas proporcionam, observamos que a modificação nos processos, seja de ordem pessoal ou estrutural, quando bem planejada, pode gerar um estado de conformidade. Se os funcionários envolvidos na mudança estão cientes e informados do que está ocorrendo, diminui a sensação de medo e insegurança e isso também alivia os boicotes que podem ser gerados.

Uma alteração significativa articulada, planejada e operacionalizada por pessoal interno e externo à organização, que tenha o apoio e a supervisão da administração superior, e atinja integradamente o componente de cunho comportamental, estrutural, tecnológico e estratégico da organização gera um bem-estar ao colaborador. (MATTOS, 2020).

De acordo com o autor, quando os processos são bem articulados geram a sensação de bem-estar. Quando os superiores comunicam o que está acontecendo e informam sobre a importância dos processos de mudanças os colaboradores passam a sentir confiança naqueles que lideram.

4 Despoletar = impedir ou travar. 


\title{
Desafios da implementação da mudança
}

São inúmeros os desafios que uma empresa enfrenta quando se vê diante de mudanças. Existem fatores como o financeiro, estrutural, profissional e cultural. Para uma mudança ser bem sucedida os aspectos devem ser planejados de forma estratégica para conseguir êxito nos resultados.

De acordo com Niemeyer (2019), a utilização de estratégias para definir o procedimento para realizar as mudanças tem função muito importante para que não se tenha imprevistos. Para a autora, a maioria das empresas adota procedimentos diferenciados para a seleção dos seus projetos, privilegiando principalmente aspectos de natureza estratégica e utilizando métodos de estimativa e rentabilidade para a maioria dos projetos. Assim, segundo a autora:

\begin{abstract}
Ao optar por fazer uma gestão da mudança, a organização deve estar ciente de que haverá inúmeros desafios a ser superado no caminho, o maior deles envolve convencer os funcionários da importância da mudança para o bom desempenho da empresa como um todo, ressaltando os benefícios que ela vai gerar direta e indiretamente para eles, podendo ser desenvolvidos oportunidades de carreiras entre outros. (NIEMEYER, 2019, p. 4).
\end{abstract}

Quando falamos de desafios em pequenas empresas todas as características são levadas em conta, mas, sobretudo, é necessário ter um estratagema ${ }^{5}$ muito bem elaborada para que as dificuldades sejam diminuídas pelo planejamento bem elaborado.

Sabendo que as mudanças já trazem alguns transtornos pelo próprio processo de implementação é de se esperar que, se não for bem ajustado, pode acarretar danos irreversíveis.

Depois de conseguir programar as mudanças faz-se necessário uma nova mentalidade nos colaboradores para que elas não sejam inúteis e que possam surtir o efeito desejado. $\mathrm{Na}$ maioria das vezes as tentativas de mudanças falham. Não é questão de apenas incrementar novas terminologias e ferramentas. Deve-se incorporar nos colaboradores uma nova mentalidade a fim de obter o resultado desejado. (ECHOLS, 2018).

É importante que as mudanças sejam realizadas sob a orientação de profissionais capacitados que saibam utilizar as ferramentas que compõem as mudanças desejadas. As alterações devem contar com um cronograma de trabalho muito bem elaborado para que não venha a ter consequências indesejáveis.

5 Estratagema $=$ plano, esquema previamente estudado e posto em prática para atingir determinado objetivo. 
Quando falamos de pequenas organizações não se tem um número muito alto de funcionários, nem renda, portanto, tais situações visam à expansão do negócio para que venha a gerar maior rentabilidade.

Para se realizar uma mudança que realmente vai trazer o resultado desejado e necessário alguns pilares devem ser observados:

a) Realizar uma gestão humanizada, dando atenção aos colaboradores;

b) Fazer o corte de gasto assertivo, não prejudicando a operação já existente;

c) Ter controle e organização para não ter gastos desnecessários;

d) Observar o cenário, tanto interno quanto o externo, para evitar qualquer imprevisto.

Naturalmente, as empresas fazem as mudanças se adequando à razão interna e externa para conseguir melhorias de processos, visando sempre à redução de gastos e aumento de lucro. "Mudanças podem ser causadas por razões internas e externas à empresa, que demandam melhorias ou alterações em algum processo.” (ECHOLS, 2018). Alguns se equivocam em visar somente os lucros. Uma mudança realizada visando só o aumento das margens pode deixar de lado o que levou a realizar as melhorias, a qualidade do serviço ou produto.

Isso pode levar às mudanças contingenciais, pois se lida com pessoas que geralmente não aceitam bem as mudanças. "Cabe destacar que a mudança organizacional é sempre contingencial, pois é diferente e refere-se à realidade e idiossincrasias ${ }^{6}$ de cada empresa". (BROWN, 1992). O autor cita ainda que:

\footnotetext{
A maior invenção que sairá dos laboratórios de pesquisa no futuro será a própria organização [...] Conforme as organizações tentam, com rápidas inovações tecnológicas, acompanhar o mercado, os departamentos de pesquisa têm de criar arquiteturas organizacionais que possibilitem à empresa ser continuamente inovadora. (BROWN, 1992, p. 1).
}

As grandes organizações possuem maior facilidade para se adequar às mudanças inesperadas, planejar as optativas e flexibilizar as pequenas mudanças, portanto, é necessário estudar todos os cenários para que as consequências sejam vantajosas, pois nas pequenas empresas percebe-se muito mais as perdas.

\section{Principais elementos para a solução}

Existem vários elementos que são utilizados no processo de mudança, tanto de tecnologias para aplicação da mudança necessária, em todo o processo a depender do tipo e necessidade da alteração, quanto na questão social e estrutural. Tudo deve ser muito bem 
observado para se obter sucesso. É necessário analisar todas as vertentes e todas as variáveis possíveis para que não haja problemas no meio do processo. Segundo Júnior (1992), ”os principais elementos para a mudança organizacional são a tecnologia, o comportamento social e as instituições e estruturas. A maioria das organizações muda em resposta às crises, sendo limitado o número de casos de atitudes proativas".

A tecnologia, quando falamos em mudança na organização, é fundamental na atualização dos sistemas para que sejam melhorados os processos. Com todas as complicações que habitam no meio de uma mudança na empresa o uso da tecnologia é um fator para que haja sucesso na troca dos procedimentos organizacionais.

Sabe-se que a mudança, na maioria dos casos, é sempre turbulenta. Mas não é porque as dificuldades aparecem que se deve desistir de uma mudança, pois ela pode ser benéfica para a empresa e isto vai gerar crescimento.

\section{Elementos para ter êxito na mudança}

a) Comunicação, planejamento, informação durante todo o processo e agir de forma pensada;

b) Treinamento dos envolvidos, pois eles devem estar inteirados e capacitados dentro dos novos processos;

c) Gerenciamento da resistência, uma vez que sempre haverá aqueles que serão contra a mudança. É necessário entender o porquê e saber administrar a situação;

d) Observar a estrutura. Deve-se verificar se o local comporta as mudanças desejadas;

e) Programar de forma segura e realizar a mudança com consciência, sabendo que as atividades foram bem planejadas. Isso diminui as margens de erro.

Quando verificamos as organizações bem sucedidas os cinco tópicos citados sempre estão bem presentes, pois são pilares essenciais para o sucesso de qualquer organização. Quando falamos de mudança, uma organização que pretende programar a gestão de processos deve se basear nesses pilares para ter sucesso.

Problemas aparecem e cabe ao gestor gerenciá-los, vencendo, através do diálogo, a resistência daqueles que estão receosos com a mudança, mostrando que não é apenas o superior e sim alguém que lhe passe certa confiança, pois assim se torna mais fácil conduzir todos os processos com todas as demais modificações necessárias.

Portanto, para se ter sucesso é muito importante ter cuidado com a parte tecnológica, estrutural, organizacional, técnica, mas é essencial ter atenção com as pessoas envolvidas na mudança, pois é através dos indivíduos que a empresa terá sucesso. Na gestão da mudança nas 
organizações, sobretudo as pequenas empresas, que geralmente não têm um capital muito grande, a dedicação e o empenho dos colaboradores serão inevitáveis para ter sucesso.

As organizações estão cada vez mais se adequando às mudanças, deixando os medos de lado e seguindo o exemplo de empresas bem sucedidas que programaram melhorias contínuas e estão bem colocadas no mercado.

Grandes e pequenas empresas devem colocar em prática a gestão de mudança, visando cada vez mais o crescimento, não parando no tempo, e sabendo cada vez mais que as mudanças para a melhoria são necessárias, gerando novos produtos/serviços, novas tecnologias e geração de renda.

\section{METODOLOGIA}

O presente trabalho tem como objeto de estudo as mudanças organizacionais em uma escola infantil. Os objetivos específicos são: a) identificar quais são os medos dos colaboradores em relação a mudança organizacional; b) definir quais são os principais desafios dos gestores para a implementação da mudança organizacional; c) identifica r métodos e estratégias que os gestores possa usar para diminuir os problemas dentro do processo de implementação das mudanças.

O campo investigativo foi a escola infantil Soldadinho do $\mathrm{Rei}^{7}$, localizada na cidade de Jaboatão dos Guararapes. O universo foi de 13 colaboradores, sendo 1 diretora, 1 porteiro, 1 secretária, 5 professoras e 5 auxiliares de classe. A pesquisa envolveu os 13 colaboradores (amostra de 100\%). A pesquisa realizada foi bibliográfica e de campo, com finalidade aplicada, análise propositiva e abordagem quantitativa. $\mathrm{O}$ instrumento de pesquisa foi um questionário semiaberto constante no apêndice.

\section{DESENVOLVIMENTO DA PESQUISA DE CAMPO}

Seguem os gráficos contendo os resultados extraídos do questionário aplicado aos gestores e colaboradores da Escola Soldadinho Rei.

7 A escola infantil Soldadinho do Rei LTDA foi fundada em 23/02/1997 por Cristiane Mendes da Silva Pereira e está localizada na Rua Bernardino Costa Lopes n¹51, Zumbi do Pacheco, em Jaboatão dos Guararapes. 


\section{CONFIANÇA NOS GESTORES EM RELAÇÃO A MUDANÇA}

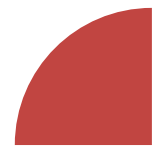

ALTA 75\%

- MÉDIO 25\%

BAIXA

A confiança em seus líderes é de extrema importância para os envolvidos na mudança, pois é sempre um processo difícil. Nessa questão, os dados de campo vão no sentido concordante, uma vez que $75 \%$ afirmaram ter confiança nos gestores nos processos de mudança organizacional.

\section{O QUE OS GESTORES FAZEM PARA QUE OS COLABORADORES VISEM DE FORMA POSITIVA AS MUDANÇAS?

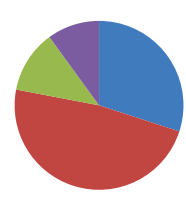

$$
\begin{aligned}
& \text { SER TRANSPARENTE } 30 \% \\
& \text { SER SINCERO } 48 \% \\
& \text { EXPLICAR A MUDANÇA } 12 \% \\
& \text { MOSTRAR OS BENEFICIOS } 10 \%
\end{aligned}
$$

No questionário aplicado conseguimos verificar que ser sincero $(48 \%)$ e explicar de forma coerente a mudança (12\%) são importantes para que a mudança organizacional ocorra de forma correta. Niemeyer (2019) cita a importância em ser sincero e explica de forma coerente aos funcionários o que vai acontecer, pois isso gera uma questão de confiança entre empregador e empregado. No questionário aplicado conseguimos verificar que vai de acordo com o que dizem os autores, pois ser transparente e sincero com os funcionários gera uma questão de confiança. 


\title{
A MUDANÇA É UMA AMEAÇA PARA OS COLABORADORES?
}

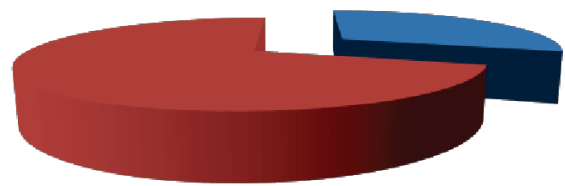

- SIM 30\%

nÃO $70 \%$

Segundo Marques (2011), a mudança gera uma percepção no status quo do indivíduo, mas de acordo com o questionário aplicado difere do que os autores dizem, pois $70 \%$ dos questionados afirmam que a confiança nos gestores anula muito a sensação de ameaça em relação às mudanças para com o colaborador.

\section{AS MUDANÇAS ORGANIZACIONAIS SÃO NECESSÁRIAS?}

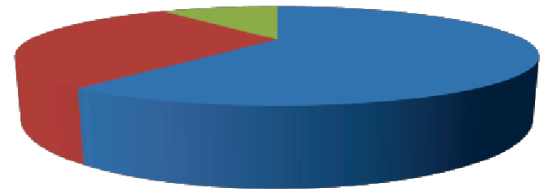

\author{
- SIM 60\% \\ — NÃO 30\% \\ EVENTUALMENTE 10\%
}

O questionário aplicado mostra que as mudanças de fato são necessárias para o crescimento da empresa. $60 \%$ dos inquiridos afirmam que as mudanças organizacionais são de fato necessárias em qualquer setor para que haja melhorias e resolução de problemas.

\section{DE QUE FORMA SÃO INFORMADAS AS MUDANÇAS?}

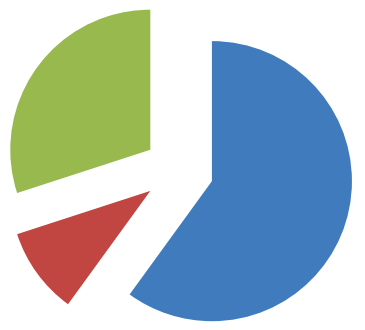

\footnotetext{
de forma direta $60 \%$

não contaria $10 \%$

informaria o minimo $30 \%$
} 
As mudanças geram muita desconfiança, mas por falta de conhecimento do que está acontecendo. A pesquisa mostra que o autor está sendo assertivo em relação ao questionário, pois nos mostra que se a mudança for comunicada de forma direta é possível obter melhores resultados, pois gera confiança no gestor em relação às mudanças organizacionais.

\section{CONSIDERAÇÕES FINAIS}

Este artigo buscou identificar os principais problemas, expondo as soluções, na implementação da mudança organizacional em uma escola de ensino infantil. Colaborando para melhorias dentro do segmento abordado foi possível verificar o quão importantes foram os resultados obtidos, podendo contribuir para pesquisas futuras.

A escola analisada teve um papel relevante na pesquisa, pois foi possível analisar os medos e receios dos colaboradores, sugerindo aos gestores realizarem as mudanças de forma assertiva e ao mesmo tempo não provocando dúvidas nos funcionários. Essa pesquisa mostra a importância da informação objetiva entre líderes e colaboradores para se ter êxito nas mudanças.

A participação dos gestores é fundamental e indispensável para o sucesso de qualquer mudança na organização ao fazer com que os colaboradores tenham melhor compreensão sobre os procedimentos utilizados. É recomendável que durante todo o processo de mudança organizacional os líderes e gestores sejam claros, diretos, justos e sinceros com os colaboradores, informando sobre as mudanças que estão ocorrendo ou que vão ocorrer, gerando assim confiança nos funcionários e em todos os envolvidos.

O ponto alto, e que não pode ser deixado de lado, é que haja integração entre funcionários e gestores, evitando as sabotagens por parte de alguns que não se sentem seguros com a mudança informada ou proposta para implementação. Os responsáveis pelo processo de mudança organizacional devem analisar todas as vertentes para que não venha a ter falhas e que resultem em danos permanentes.

\section{REFERÊNCIAS}

BRONW, S. John. Mudança organizacional: uma abordagem preliminar.

Disponível em: https://www.fgv.br/rae/artigos/revista-rae-vol-32-num-3-ano-1992-nid-46080/ Acesso em: 17 abr. 2021.

ECHOLS, Tônia. Mudanças organizacionais: o que são, exemplos, e como programar. Disponível em: https://www.sbcoaching.com.br/blog/mudancas-organizacionais/ Acesso em: 11 dez. 2020. 
FONSECA, J. A. Gestão da mudança organizacional: uma revisão teórica. Disponível em:http://bibliotecadigital.fgv.br/dspace/bitstream/handle/10438/11826/Gest\%C3\%A3o\%20d a\%20Mudan\%C3\%A7a-Uma\%20Revis\%C3\%A3o\%20Te\%C3\%B3rica.pdf?sequence=1.

Acesso em: 18 Abr. 2021.

JÚNIOR, Wood Thomas. Mudança organizacional: uma abordagem preliminar. disponível em: http://www.fgv.br/rae/artigos/revista-rae-vol-32-num-3-ano-1992-nid-46080/ Acesso em: 12 dez. 2020.

JUSTAS, Marcelo. Gestão da mudança \& Lean manufacturing: transformando operações em vantagens competitivas sustentável. 1. ed. Curitiba: Ed. do autor, 2016.

MARQUES, José. Ibccoaching e gestão de pessoas.

Disponível em: https://www.ibccoaching.com.br/portal/rh-gestao-pessoas/.

Acesso em: 11 dez. 2020.

MATTOS, Lissandra. As mudanças organizacionais e seus gestores na empresa na era da informação. Disponível em: http://bibliotecadigital.fgv.br/dspace;/handle/10438/3671.

Acesso em: 11 dez. 2020.

NIEMEYER, Marina. Gestão da mudança: ferramenta estratégica para empresas. Disponível em: https://www.passeidireto.com/arquivo/17877584/gestao-da-mudanca.

Acesso em: 11 dez. 2020.

\section{APÊNDICE A - Questionário aplicado através de um formulário com perguntas semiabertas}

1 - Você se sente ameaçado (a) quando a organi zação propõe mudanças? Por quê ?

( ) $\operatorname{sim}$ ( ) não Justificativa

2 - Quais são os seus principais medos com a mudança?

3 - Qual o nível de relevância que o gestor possui no processo de mudança?

( ) baixo ( ) médio ( ) alto

4 - O que o gestor (a) poderia fazer para que os colaboradores vissem de forma positiva a mudança organizacional ?

5 - Você acha a mudança organizacional necessária? Justifique?

( ) $\operatorname{sim}$ ( ) não Justificativa

6 - Quais são os principais desafios que você vê quando o gestor (a) enfrenta o processo de mudança? 
7 - No caso de uma mudança organizacional que não concorde, qual a sua atitude mediante a situação. Aceitaria sem questionar ou iria tentar mudar a decisão tomada? Justifique.

8 - Você acha que no processo de mudança a organização deve se adequar aos funcionários e ser flexíveis na mudança ou os funcionários devem se adequar às mudanças, procurando se adaptar às novas diretrizes? Justifique.

9 - Você acha que se o gestor informar aos colaboradores o porquê da mudança os problemas serão diminuídos?

10 - Se não concordar com uma mudança organizacional, como faria para tentar reverter essa mudança?

11 - Você acha a mudança organizacional necessária? Justifique.

12 - Como você informaria uma mudança aos seus colaboradores? 


\title{
O IMPACTO DO E-SOCIAL PARA OS PROFISSIONAIS DE CONTABILIDADE EM UM MUNICÍPIO DA REGIÃO METROPOLITANA DO GRANDE RECIFE
}

\author{
https://dx.doi.org/10.48097/2674-8673.2022n6p14
}

\author{
Benjamim Muniz Oliveira Pompeu ${ }^{1}$ \\ Diego Rafael da Silva ${ }^{2}$ \\ Vanuza de Fátima dos Santos ${ }^{3}$ \\ Tarciana Borges Ferreir $a^{4}$
}

\section{RESUMO}

O objetivo deste artigo foi abordar as dificuldades apresentadas pelos usuários da plataforma e-Social. A pesquisa de campo contou com um grupo de aproximadamente 40 profissionais da área contábil que atuam na cidade de Jaboatão do Guararapes e que estão diariamente utilizando a plataforma. A pesquisa mostrou que a grande maioria dos respondentes entende que o e-Social é uma forma de avanço em suas profissões, deixando o ambiente contábil mais seguro para os empregadores, utilizando informações com maior nível de confiabilidade para o governo e a sociedade em geral.

Palavras-chave: Ambiente contábil. Dificuldades. Plataforma e-Social.

Data de submissão: 22/09/2021

Data de aprovação: 09/11/2021

\begin{abstract}
The aim of this article was to address the difficulties presented by users of the e-Social platform. The field research included a group of approximately 40 accounting professionals who work in the city of Jaboatão do Guararapes and who are using the platform daily. The survey showed that the vast majority of respondents understand that e-Social is a way to advance their professions, making the accounting environment safer for employers, using information with a higher level of reliability for the government and society in general.
\end{abstract}

Keywords: Accounting environment. Difficulties. e-Social platform.

\section{INTRODUÇÃO}

Em 11 de dezembro de 2014 o Congresso Nacional aprovou o Decreto Federal $8.373 / 14$, que trazia em seu teor a criação de um novo sistema de escrituração digital

\footnotetext{
${ }^{1}$ Concluinte do curso de Ciências Contábeis da Faculdade Metropolitana da Grande Recife.

E-mail: benjamim.muniz@gmail.com

${ }^{2}$ Concluinte do curso de Ciências Contábeis da Faculdade Metropolitana da Grande Recife.

E-mail: diego.rafae102@hotmail.com

${ }^{3}$ Concluinte do curso de Ciências Contábeis da Faculdade Metropolitana da Grande Recife.

E-mail: vanuza2007fs@gmail.com

${ }^{4}$ Docente orientadora do curso de Ciências Contábeis da Faculdade Metropolitana da Grande Recife.

E-mail: tarciana@metropolitana.edu.br
} 
chamado e-Social. Esse sistema foi criado com o intuito de facilitar a coleta de informações geradas pelas empresas e órgãos públicos em todo o território nacional e ter um maior controle fiscal sobre elas.

Começa, então, uma corrida das organizações e órgãos públicos na busca de informações e de conhecimento a respeito do e-Social. Conforme o site do e-Social (2016), essa nova fase da informação previdenciária e social visa unificar, racionalizar e harmonizar os dados gerados pelos programas de departamento pessoal e contábil das empresas. Essas informações chegam aos órgãos como a Receita Federal, Previdência Social, Ministério do Trabalho e Caixa Econômica Federal de forma que eles possam cruzá-las e obter análises refinadas a partir de um volume significativo de dados com diferentes atributos.

A conjuntura do e-Social apresentada em seus conceitos e esquematizações demonstra clareza e objetividade, mas para que isso ocorra de forma harmoniosa os sistemas de dados das empresas precisam estar corretamente alimentados. Porém, quem trabalha no Departamento Pessoal sabe que isso não é tarefa fácil, principalmente em órgãos públicos, onde a resistência à mudança é ainda maior.

\section{REFERENCIAL TEÓRICO}

A exigência de profissionais capazes de quebrar velhas regras, capazes de serem pessoas que abram novos horizontes e aceitem riscos pode ser, no contexto atual, uma das principais preocupações no universo da formação acadêmica. Assim, Franco (1999) afirma que "apenas informações não mudam os comportamentos. É preciso agir de acordo com elas". Vivemos na era das mudanças. Tudo muda muito rapidamente, em todos os campos da vida. Há algumas décadas, algumas características evidenciam o bom profissional. Nesse mercado exigente e competitivo essas características mudaram muito para atender às novas demandas do mercado de trabalho. Para o novo perfil profissional é fundamental considerar atitudes como:

[...] iniciativa, liderança, criatividade, autodesenvolvimento, multifuncionalidade, agilidade, flexibilidade, gerenciar o risco, educador, lógica de raciocínio, prontidão para resolver problemas, habilidade para lidar com pessoas, trabalho em equipe, conhecimento de línguas, informática e resistência emocional [...]. (FRANCO, 1999, p. 33).

Para esse novo profissional conquistar seu espaço no mercado de trabalho, não bastam somente características pessoais, exige-se constante busca de conhecimentos, não somente ligado a sua área específica, exige-se formação continuada. Assim, Franco (1999) afirma que "o autodesenvolvimento inclui também, ao lado das características de comportamento, a aquisição continuada de conhecimentos dentro e fora de sua área de atuação”. (FRANCO, 1999, p. 35). 
Nesse mercado em contínuas transformações, o profissional precisa estar preparado para as mudanças e entender rapidamente esse processo para se adequar a elas e propor ações, desenvolvendo seu potencial criativo.

A contabilidade é uma área muito ampla. O profissional, por sua formação, pode atuar em diversos campos como: contabilidade privada, pública, perícia contábil, controladoria, etc. Dentre essas áreas de atuação do profissional contábil, ele pode ainda vir a atuar como empregado, empregador ou como profissional liberal. O contador lida todos os dias com o que é apontado como um dos bens mais preciosos de uma economia: a informação contábil. Neste sentido, destaca-se o valor do contador perante a sociedade em geral e o sentido que torna um perfil profissional contextualizado, situado histórico, social e culturalmente.

Em qualquer área que esse profissional possa atuar, informação e conhecimento apresentam-se com grande relevância. Como afirma Lisboa (1997):

[...] De maneira genérica, pode ser afirmado que todas as decisões tomadas envolvendo as atividades de uma empresa, qualquer que seja o nível dessa decisão, têm por base algum tipo de informação. Nesse contexto, o profissional de contabilidade tem papel importante [...]. (LISBOA, 1997, p. $37)$.

Muitas pessoas necessitam e fazem uso de informações que são elaboradas pelos contadores e cada um desses usuários requer um tipo específico de informação que é utilizada para decisões de diferentes naturezas. Conforme esclarece Lisboa (1997): “O papel do contabilista é suprir com informações desejadas a cada um desses usuários, na medida de suas necessidades, sem buscar o benefício ou o privilégio de qualquer um em particular". (LISBOA, 1997, p. 38).

Além dos campos de atuação sinalizados, outro campo de atuação do profissional contábil que tem vital importância para o desenvolvimento da contabilidade nas camadas sociais é o profissional docente. Cabe a este profissional, na área de contabilidade, além de transmitir e ensinar os princípios fundamentais da contabilidade e a sua prática comum, desenvolver o senso crítico, o comprometimento, a responsabilidade e a ética nos estudantes com os quais atua.

Nas empresas tudo muda continuamente. $\mathrm{Na}$ era da informação essas mudanças ocorrem com uma velocidade sem limites. A tecnologia como caminho da informação faz esse processo de aceleração, portanto, é necessário que a contabilidade e o contabilista se adaptem a novas formas e processos de gestão.

A evolução do ambiente econômico e social no qual o contador atua exige uma grande parcela de conhecimentos e habilidades. O profissional contábil é responsável pelo levantamento de dados que interessam aos usuários da contabilidade, assim seu papel é estar 
esclarecendo dúvidas, solucionando problemas e desenvolvendo o aspecto estrategista, já que é o grande auxiliador da tomada de decisões dentro das organizações. O profissional deve estar preparado para atuar nas tomadas de decisões, visando corrigir as dificuldades que surgem ao longo do caminho. Conforme frisa Silva (2000): "O mercado atual requer modernidade, criatividade, impondo com isso, um desafio: o de continuar competindo". (SILVA, 2000, p. 26).

A era da informação passou a ser um desses elementos básicos para que esse profissional modifique suas características e sua forma de atuação nas organizações. Para Perez (1997), o objetivo da profissão contábil “[...] vai mais além de acumular cifras para preparar um balanço para efeitos impositivos. Vai mais além de registrar automaticamente uma ou várias operações: um software adequado pode produzir melhor as rotinas.” (PEREZ, 1997, p. 68).

A profissão contábil oferece várias possibilidades de atuação, de especialização. Essas, porém, se assemelham muito a elementos essenciais que vêm sendo exigidos desses profissionais. De acordo com Mussolini (1994): “O contador deve se conscientizar de que a valorização se fundamenta, essencialmente, em dois pontos básicos: a) indiscutível técnica; e b) irrepreensível comportamento ético". (MUSSOLINI, 1994, p. 79).

Além de todas as características que se exigem atualmente desse profissional, existe também o elemento fundamental para qualquer profissão: o comportamento ético. A ética profissional dentro dessa área é de suma importância, visto que este trabalha em diversas áreas, presta serviços para diversas pessoas e é um elemento muito importante no cenário econômico, já que é uma peça-chave na tomada de decisões dentro das organizações.

A profissão contábil, assim como qualquer outra, é exercida na combinação da competência com a ética. Assim, a competência é fazer o certo e a ética exige que seja feito de maneira correta, repercutindo na boa reputação da profissão, na atuação social.

Essa nova visão de mercado, todo o avanço tecnológico e a globalização como centro desse novo paradigma mudou e continuará mudando de forma cada vez mais acelerada as exigências profissionais, em especial destaque nesse estudo, o contador.

\section{E-Social: contextualização}

A área trabalhista das empresas é executada por profissionais de departamento de pessoal e é uma das áreas de alta relevância e que exige uma imensa gama de conhecimentos, não só do próprio departamento de pessoal, como também de outras áreas afins, devido à quantidade de legislações trabalhistas, previdenciárias e civis aplicadas no desenvolvimento dos cálculos e informações que são geradas ao fisco. 
Com a necessidade do fisco em controlar e melhorar as novas exigências legais foi constituído o Sistema Público de Escrituração Digital (SPED), uma forma de controlar a movimentação fiscal das empresas, que antes era via papel ou enviadas mensalmente em diferentes plataformas, passando a ser online.

Surge o Sistema de Escrituração Digital das Obrigações Fiscais, Previdenciárias e Trabalhistas (e-Social), instituído pelo Decreto $n^{\circ} 8.373$ de Dezembro de 2014, que envolve a Receita Federal, o Ministério da Economia, a Previdência Social e a Caixa Econômica Federal, tendo por objetivo a unificação da prestação de informações referentes à escrituração das obrigações fiscais, previdenciárias e trabalhistas e tem por finalidade padronizar sua transmissão, validação, armazenamento e distribuição.

O e-Social não cria, altera ou suprime a legislação vigente e nem qualquer das obrigações previdenciárias, trabalhistas e tributárias, mas surgiu para racionalizar o cumprimento das obrigações já existentes. A proposta do e-Social alterou vários aspectos na forma do cumprimento das obrigações acessórias, trazendo uma nova realidade nas rotinas do departamento de pessoal, fazendo com que os controles internos sejam instrumentos de grande valia para o cumprimento efetivo do e-Social, uma vez que eles auxiliam na gestão. A grande preocupação das empresas no que concerne ao cumprimento das obrigações perante o fisco federal, estadual e municipal tem crescido expressivamente nos últimos tempos e com isso a necessidade de adaptações dos processos de informação nas empresas que precisam ser revistos, alguns adaptados, outros implantados, para evitar que o fisco aplique suas penalidades em caso de descumprimento de todas as obrigações em tempo hábil.

Como o e-Social é um programa de centralização de informações trabalhistas e previdenciárias, antes informado em diversas plataformas e agora em uma única forma de envio, tem feito com que os profissionais juntamente com os gestores das empresas mudem sua forma de controlar e enviar tais informações ao fisco. Fatos estes demonstram a importância do estudo da forma mais viável de entrega do e-Social, esclarecendo suas funcionalidades.

\section{As mudanças provocadas pelo e-Social}

O avanço da tecnologia possibilitou o surgimento do Sistema Público de Escrituração Digital (SPED), o qual permitiu que as informações referentes à escrituração contábil e fiscal das empresas passassem a ser agrupadas e transmitidas de forma digital com o intuito de agilizar processos, unificar procedimento para o contribuinte, além de realizar o cruzamento de dados pelos órgãos fiscalizadores, identificando ilícitos mais rapidamente. Para Oliveira (2014): 
[...] O eSocial é um projeto do governo federal que vai coletar as informações descritas no Objeto do eSocial, armazenados no Ambiente Nacional do eSocial, possibilitando aos órgãos participantes do projeto, sua efetiva utilização para fins previdenciários, fiscais e de apuração de tributos e do FGTS [...]. (OLIVEIRA, 2014, p. 42).

De acordo com Hughes (2003 apud DIAS, 2008, p. 51) o e-Gov e a NGP podem "até ser vistos como parte do mesmo movimento". As estratégias para a reforma administrativa devem explorar os potenciais da comunicação eletrônica visando "contornar as hierarquias formais, as barreiras organizacionais, as distâncias físicas e dificuldades de acesso à informação". (FERNANDES, 2004, p. 107).

O objetivo principal do e-Social é realizar a substituição de forma gradativa de algumas declarações, como por exemplo: Livro de Registro de Empregados, Folha de Pagamento, Comunicação de Acidente de Trabalho, Termo de Rescisão, Formulário de Seguro Desemprego, Caged, Rais, Sefip, Gefip, DirfCat, PPP e o Manad, transformando-os em uma só declaração. Esta declaração funcionará da seguinte maneira: o empregador gera um arquivo para a Receita Federal, tendo eventos mensais e tempestivos, ficando alocados em um banco de dados onde as entidades poderão buscar informações assim como os próprios empregados. (DOS SANTOS, 2017).

O e-Social é a escrituração digital da folha de pagamento e das obrigações trabalhistas, previdenciárias e fiscais. Ele é considerado o projeto mais complexo do SPED, em que ele é planejado de forma conjunta por diversos órgãos e instituições como o Ministério do Trabalho e o Instituto Nacional de Seguridade Social. (REICHERT, 2015).

Criado através o Decreto de $\mathrm{n}^{0} 6.022$ de 22 de janeiro de 2007 e aprovado a partir do Ato Declaratório Executivo $\mathrm{n}^{\mathrm{o}}$ 5, de 17 de julho de 2013, o projeto foi embasado legalmente no SPED. Desta forma, a Caixa Econômica Federal e a Receita Federal do Brasil definiram vários pontos para este projeto, incluindo a criação do Comitê Diretivo e do Comitê Gestor do e-Social. (RIBEIRO, 2015).

Segundo Caon (2017), a compreensão das mudanças que este novo sistema proporciona no cenário atual é necessário que todas as empresas sigam alguns procedimentos operacionais antes da implementação do e-Social para encaminharem as informações trabalhistas de seus colaboradores para os órgãos competentes, de acordo com o Manual de Orientação do e-Social (BRASIL, 2013), conforme citado por Caon (2017), tais como: Registro do Empregado, Folha de Pagamento, Cadastro de Empregados e Desempregados (CAGED), Relação Anual Geral de Informações Sociais (RAIS), Declaração de Imposto de Renda Retido na Fonte (DIRF), Comunicação de Acidente de 
Trabalho (CAT), Perfil Profissiográfico Previdenciário (PPP), Manual Normativo de Arquivos Digitais (MANAD), Guia de Recolhimento do FGTS (GFIP), Termo de Rescisão e Formulário do Seguro Desemprego ${ }^{5}$. Segundo Filho (2015), as mudanças do e-Social chegam com a missão de promover o cumprimento das obrigações tributárias, estabelecendo padrões por um único canal, para um ambiente compartilhado entre os diversos órgãos da Administração Pública.

\section{Os desafios, benefícios e os impactos do sistema e-Social para o profissional contábil}

A implantação do e-Social não faz com que a legislação trabalhista mude, mas exigirá que a mesma seja cumprida de forma correta. Entretanto, será necessário que os usuários do sistema estejam adaptados e atentos às novas exigências.

O e-Social é considerado por alguns profissionais como um sistema de grande complexidade, no qual impactará na rotina das organizações e principalmente dos escritórios de contabilidade, uma vez que a maioria das empresas tem seus serviços de departamento de pessoal feito por terceiros. Diante de tamanha mudança é possível destacar alguns impactos como: na cultura dos escritórios, o envio imediato de informações dos colaboradores, cumprimento da legislação em vigor. De forma a exemplificar um dos impactos é possível ressaltar o aviso de férias, que conforme a legislação trabalhista o prazo para concedê-lo ao empregado é de 30 dias, mas na maioria dos casos isso não acontece e esse aviso acaba sendo assinado juntamente com o recibo das férias. Perante a lei é incorreto e com a implantação do e-Social essa situação não poderá ocorrer. (BEZERRA, 2014, p. 12).

De acordo com Frari (2015, p. 55), o novo projeto trará modificação cultural na forma de executar os procedimentos relacionados à rotina trabalhista, ou seja, afetará os sistemas internos e os processos diários de empresas e escritórios, além de causar impacto na reestruturação do sistema operacional, já que as tabelas deverão estar atualizadas e ajustadas de acordo com as exigências do e-Social.

A implantação do e-Social trará um impacto considerável para os escritórios contábeis no que diz respeito à troca de informações, podendo este ser um dos pontos mais

\footnotetext{
5 O SPED - Sistema Público de Escrituração Digital foi instituído através do Decreto 6.022/2007. Folha de Pagamento, Cadastro de Empregados e Desempregados (CAGED), Relação Anual Geral de Informações Sociais (RAIS), Declaração de Imposto de Renda Retido na Fonte (DIRF), Comunicação de Acidente de Trabalho (CAT), Perfil Profissiográfico Previdenciário (PPP), Manual Normativo de Ar quivos Digitais (MANAD), Guia de Recolhimento do FGTS (GFIP), Termo de Rescisão e Formulário do Seguro Desemprego.
} 
delicados na rotina do escritório, já que as informações trocadas entre os usuários do sistema e as empresas deverão ser muito alinhadas e rápidas, evitando penalidades.

Pode-se destacar outro impacto que será a necessidade de tornar a transmissão dos dados para o sistema do governo mais ágil. Muitos eventos, tais como contratações e rescisões deverão ser informadas diariamente, com risco de penalidades para a empresa que não cumprir com a determinação. Como exemplificação de um lançamento que deverá ser feito de forma imediata no e-Social temos a alteração de salário que deverá ser informada no máximo até o dia subsequente ao seu acontecimento.

Entretanto, com o surgimento do e-Social, é essencial que haja uma análise documental, tributária, previdenciária e trabalhista, para que seja possível se prevenir de eventuais riscos e penalidades tanto para a organização quanto para o profissional responsável pela execução da prestação de serviço. (JORNAL CONTÁBIL, 2015).

Percebe-se que a implantação do e-Social vai além de mudanças e impactos na rotina de um escritório contábil e no relacionamento entre empresa, colaboradores e profissionais contábeis. Esse sistema digital será uma grande mudança cultural e tecnológica que exigirá técnica, capacitação, agilidade e transparência na troca de informações, fazendo com que seja mais frequente o uso da gestão contábil.

Os primeiros passos do e-Social deu-se com o módulo do empregador doméstico. Em Junho de 2014 criou-se o portal www.esocial.gov.br. Trata-se de um ambiente totalmente online, permitindo assim o envio unificado de informações e cumprimento das obrigações trabalhistas. O e-Social abrangerá todas as empresas, bem como todos os empregados do país, quando for implantado em sua totalidade. (REICHERT et al., 2016).

Para a Receita Federal este projeto objetiva aprovar de forma efetiva os direitos trabalhistas e previdenciários; simplificar o cumprimento das obrigações principais e acessórias, buscando a redução de custos e informalidades; aprimorar as relações de trabalho e a qualidade da informação; aumentar a arrecadação por meio da redução da inadimplência, erros, sonegação e fraudes; agilidade no acesso à informação, tornando a fiscalização mais efetiva, com o cruzamento de dados, auditoria eletrônica, atendendo a diversos órgãos governamentais a partir de uma única escrituração e declaração. Com a implementação do novo sistema do e-Social algumas obrigações acessórias passaram a ser resumidas em uma única guia, diminuindo a transmissão para vários órgãos da mesma informação, na qual serão substituídos cerca de $80 \%$ das obrigações acessórias pelo eSocial, facilitando, assim, o envio das informações. (OLIVEIRA, 2014).

Conforme De Azevedo et al (2014), o Departamento Pessoal ficou sendo o 
responsável :

[...] por cuidar de toda a parte burocrática, como admissões e demissões de funcionários, cálculos e fechamento de folha de pagamento onde gera os impostos a pagar, cálculo de rescisão de contrato, concessão de férias, afastamentos, $13^{\circ}$ salário, faz cumprir a lei segundo a CLT (Consolidação das Leis do Trabalho). (DE AZEVEDO, et al. 2014, p. 110).

As necessidades de adaptabilidade são as ações necessárias para o atendimento da nova obrigação que será o e-Social, sendo que para Marin, Silva e Gonçalves (2015), levando em conta as mudanças que o e-Social irá trazer para as empresas depois de sua implantação, o processo pré-sistema deverá atender as seguintes etapas: conscientização organizacional a partir dos gestores; revisão de processos internos com foco em integração; promoção da reciclagem de conhecimentos das leis e regulamentações; verificação da mudança de perfil do profissional do RH e Departamento Pessoal, vist o a responsabilidade perante ao e-Social.

Já segundo a PwC Brasil (2014, p. 16), “o processo de adequação é muito mais amplo do que apenas um ajuste de sistema", sendo que existem cinco grandes frentes que devem ser preparadas para o e-Social, tais quais: pessoas; tecnologia; revisão trabalhista, previdenciária e fiscal; processos e estrutura e governança. Em relação à tecnologia, será primordial uma avaliação de suas deficiências e limitações de sistema e infraestrutura considerando a nova demanda. Quanto aos processos, estes devem ser analisados no que diz respeito a sua efetividade e controle, sendo que seus fluxos, requisitos, políticas e forma de controle devem ser revisados de modo que se alcance uma melhoria na sua gestão e otimização de esforços. De acordo com a PwC Brasil (2014) a perspectiva é de que a sistematização do envio das informações do e-Social vai demandar racionalização e automatização de processos e esses aspectos confirmam a necessidade premente das empresas de investir em soluções administrativas de integração de sistemas, gerenciamento eletrônico de informações e ferramentas de workflow. Segundo Schülter (2019), "Esta fase é mais tranquila, porque o e-Social ainda não é tido como a entrega oficial”, explica. "Os três primeiros meses são de adaptação, e a entrega oficial para o Governo continua sendo a Sefip. ( SCHULTER, 2019).

De acordo com o portal da Receita Federal do Brasil (2019), após a total implantação do e-Social, trará vantagens para os empregadores e empregados. Ao serem perguntados com relação às vantagens com a implantação, 60,4\% acreditam que o cumprimento da lei por partes das empresas seja a principal vantagem. 58,5\% acreditam que as dificuldades de cometer fraudes seja a principal vantagem. 41,5\% acreditam que a principal vantagem é o maior acesso/clareza e a qualidade das informações. Segundo a 
Receita Federal do Brasil, com a simplificação dos processos, haverá ganho de produtividade, diminuindo os erros nos cálculos da geração de guias para o recolhimento do FGTS e os demais tributos. A plataforma garantirá maior segurança jurídica, principalmente para as empresas que trabalham em conformidade com a legislação.

Uma grande vantagem desta plataforma é que ela se trata de um sistema que poderá se integrar a uma solução ou a um software que a empresa já utiliza. Não é um programa que será preciso baixar, instalar e que ocupará espaço no disco rígido de seu computador. Obrigatoriamente serão mais de 40 tipos de informações a serem cadastradas na plataforma. Mas, para que o sistema cumpra seu papel e traga benefícios reais às companhias e aos trabalhadores é importante que a comunicação entre as duas partes seja aberta e transparente. O empregador deve manter os dados dos seus colaboradores sempre atualizados, mas também cabe a eles informar toda e qualquer mudança. Por exemplo: uma funcionária se casa e agrega o sobrenome do marido ao seu. Neste caso ela deve alterar todos os seus documentos, tais como RG, CPF, CNH, Carteira de Trabalho, procurar a Caixa Econômica Federal para alteração de PIS e FGTS e ainda comunicar ao Departamento de Recursos Humanos sobre estas mudanças. Iniciativas como essa podem prevenir futuros problemas, como atrasos no saque do FGTS ou no recebimento do segurodesemprego, por exemplo. Ao manter todas as informações atualizadas haverá maior agilidade no acesso aos benefícios e, principalmente, o fim das ações de pessoas de má fé e dos inúmeros golpes que atingem os contribuintes brasileiros.

São inúmeras as vantagens que o e-Social proporciona à empresa que estiver adequada. Já citamos algumas delas, como a melhoria dos processos, a redução de tempo e o acesso mais simplificado às informações da plataforma. Também é importante ressaltar que a empresa poderá contar com o recurso de backup de suas informações, eliminando o uso de arquivos em papel, ou seja, reduz também as despesas com o armazenamento e manutenção de documentos e ainda reduz o uso de papel, colaborando com a diminuição do desmatamento.

\section{METODOLOGIA}

O objetivo deste artigo é direcionar a plataforma e-Social e as dificuldades apresentadas pelos usuário da mesma. Desta forma, o objetivo geral é identificar e analisar tais dificuldades como adaptação e conhecimento, encontradas pelos profissionais que fazem uso da plataforma e-Social, dando embasamento aos seguintes objetivos específicos: identificar, verificar, e propor soluções para as dificuldades encontradas. 
O universo a ser investigado será entre alguns usuários do e-Social da cidade de Jaboatão dos Guararapes, por meio de coleta de dados via questionário, elaborado de forma virtual, através do formulário do Google Docs (conforme apêndice) e divulgado individualmente aos profissionais contábeis em seus respectivos e-mails e redes sociais, de forma conveniente. A amostra desta pesquisa será probabilística, devido ao fato de que cada usuário terá a mesma probabilidade de ser selecionado para a amostra.

O desenvolvimento da pesquisa, quanto a forma, será bibliográfica e de campo. Quanto à finalidade será de forma aplicada. Em relação ao método de análise a pesquisa será propositiva, e quanto a abordagem será quantitativa. O grupo abordado será de aproximadamente 40 profissionais da área contábil, que atuam na cidade de Jaboatão dos Guararapes, e que estão diariamente utilizando a plataforma. Como mencionado anteriormente o instrumento utilizado nesta pesquisa será um questionário fechado com alternativas de múltipla escolha.

\section{PESQUISA DE CAMPO}

A pesquisa teve o objetivo de verificar a familiarização dos profissionais de contabilidade no tocante ao processo de implantação e funcionalidade do e-Social. A população que foi escolhida pela equipe se localiza na Região Metropolitana do Recife, formada por profissionais que trabalham em escritório de contabilidade, contadores, donos de escritório de contabilidade e de pessoas que de alguma forma atuam na contabilidade de empresas privadas. O critério foi pelo contato e conveniência com as pessoas que aceitaram fazer a pesquisa.

Como instrumento de coleta de dados foi utilizado o Google formulário, distribuído via e-mail para o grupo escolhido para participar da pesquisa. Após o tratamento das respostas foram obtidos os dados expostos na tabela 01 .

Tabela 01 - Coleta de dados por meio do formulário

\begin{tabular}{|c|c|c|}
\hline VARIÁVEIS & FREQUÊNCIA & (\%) \\
\hline Idade & 34 & 85 \\
\hline 18 a 49 anos & 3 & 7,5 \\
\hline 50 a 60 anos & 3 & 7,5 \\
\hline Mais do que 60 anos & 32 & 80 \\
\hline Tempo de trabalho na área? & 8 & 20 \\
\hline 1 a 10 anos & & \\
\hline Mais de 10 anos & & \\
\hline $\begin{array}{c}\text { Qual o nível de Formação na } \\
\text { area de contabilidade? }\end{array}$ & & \\
\hline
\end{tabular}




\begin{tabular}{|c|c|c|}
\hline Superior (Graduação); & 29 & 72,5 \\
\hline Técnico & 11 & 27,5 \\
\hline $\begin{array}{c}\text { Que área desempenha as suas } \\
\text { atividades? }\end{array}$ & & \\
\hline Área fiscal & 10 & 25 \\
\hline Área contábil & 5 & 12,5 \\
\hline Área DP & 12 & 30 \\
\hline $\begin{array}{c}\text { Todas às áreas (fiscal, contábil, } \\
\text { DP). }\end{array}$ & 13 & 32,5 \\
\hline
\end{tabular}

Fonte: os autores

Em relação aos entrevistados, foi possivel identificar as seguites informações: $85 \%$ dos respondentes possuem idade entre 18 a 49 anos, demontrando ser um público adepto a tecnologia e a sistemas de trocas de dados na internet. Cerca de $80 \%$ deles atuam há quase 10 anos na área, constituindo uma amostra que já tem certa experiência dentro do escritório de contabilidade.

Em relação ao nível de escolaridade dos respondentes, cerca de $72 \%$ dos entrevistados possuem a graduação em Ciências Contábeis e 32,5\% deles atuam em todas as áreas do escritório, demostando ter conhecimento em todas as demandas.

\section{Características das variáveis e percepção}

Os resultados e as análises relacionados com a percepção dos respondentes, quanto ao processo a serem adotados no preenchimento das informações para o e-Social, foram tratados na tebela 02 .

Tabela 02 - Coleta de dados por meio do formulário

\begin{tabular}{|c|c|c|}
\hline VARIÁVEIS & FREQUENCIA & \\
\hline $\begin{array}{c}\text { Já fez algum curso, treinamento } \\
\text { ou participou de palestras, } \\
\text { congressos, entre outras sobre o } \\
\text { e-Social? }\end{array}$ & & \\
\hline Sim & 25 & 62,5 \\
\hline Não & 15 & 37,5 \\
\hline $\begin{array}{c}\text { Qual o ramo de atividades } \\
\text { empresariais é mais volumoso } \\
\text { entre os seus clientes? }\end{array}$ & & \\
\hline Indústria & 4 & 10 \\
\hline Serviços & 15 & 37,5 \\
\hline Comércio & 18 & 45 \\
\hline Igualitário & 3 & 7,5 \\
\hline $\begin{array}{c}\text { Você acha que a criação do e- } \\
\text { Social contribuiu para a redução } \\
\text { do volume de trabalho? }\end{array}$ & & \\
\hline
\end{tabular}




\begin{tabular}{|c|c|c|}
\hline Sim & 24 & 60 \\
\hline Não & 8 & 20 \\
\hline Indiferente & 8 & 20 \\
\hline $\begin{array}{c}\text { Quais as mudanças promovidas } \\
\text { pelo escritório de contabilidade } \\
\text { ou setor contábil na implantação } \\
\text { do e-Social? }\end{array}$ & 13 & \\
\hline Treinamentos & 9 & 32,5 \\
\hline $\begin{array}{c}\text { Aquisição de softwares e } \\
\text { equipamentos }\end{array}$ & 6 & 22,5 \\
\hline Revisões de rotinas & 12 & 15 \\
\hline $\begin{array}{c}\text { Orientação aos seus clientes } \\
\text { quanto a temática do e-Social }\end{array}$ & & 30 \\
\hline $\begin{array}{c}\text { Quanto você acha que o seu } \\
\text { departamento ou escritório de } \\
\text { contabilidade está preparado } \\
\text { para atender as exigências do e- } \\
\text { Social: } 0-3 \text { (regular), 4-6 (bom), } \\
7-10 \text { (ótimo)? }\end{array}$ & & \\
\hline $0-3$ & 7 & \\
\hline $4-6$ & 13 & 17,5 \\
\hline $7-10$ & 20 & 52,5 \\
\hline
\end{tabular}

Fonte: os autores

Em relação à tabela 02 obseva-se que 62\% dos respondentes já fizeram algum curso ou teinamento em busca de mais conhecimento para envio das informações para o eSocial, demontrando uma preocupação com a qualidade do envio dos dados de forma correta e que não venha a prejudicar os empregadores. Grande parte dos entrevistados (45\%) atua em empresas participantes do comércio da região, conciderada um dos maiores polos de contratação, tanto de forma efetiva como de forma temporaria. $60 \%$ dos respondentes acham que a criação do e-Social contribuiu com a redução de volume de trabalho dentro dos escritórios de contabilidade, haja vista a centralização do banco de dados do goveno federal se situar em um único local.

Diante do exposto, percebemos que a amostra entende que o insvestimento em treinamento é um ponto muito importante para que haja um aumento de conhecimento para o envio do e-Social e 50\% dos respondentes julgam que seus escritórios estão em um nível ótimo de preparo para a utilização da ferramenta disponibilizada pelo governo para a utilização integrada com os sistemas de contabilidade atuantes no mercado, de forma a fazer o tratamento das informações dentro do próprio sistema antes do envio para a plataforma do e-Social. 


\section{CONSIDERAÇÕES FINAIS}

Esse artigo irá contribuir para a identificação das dificuldades de alteração na legislação referente a nova obrigatoriedade, sendo esta a Escrituração Fiscal Digital (eSocial), trazendo à tona o principal objetivo da criação do e-Social para os escritórios de contabilidade.

$\mathrm{Na}$ pesquisa de campo foi montado um questionário com 10 (dez) questões. Indentificamos que o público entrevistado é considerado jovem, demonstrando ser um público adepto a tecnologia já existente no mercado contábil e com certo acúmulo de tempo na atuação da profissão. O perfil profissional é de quem tem vivência em todos os setores do escritório, aparentando serem os fundadores de seus próprios escritórios, demonstrando domínio e assertividade no assunto abordado neste artigo.

Notamos também que a grande maioria entende que o e-Social vem como forma de avanço em suas profissões, deixando um ambiente com mais segurança a nível de informação por parte dos empregadores, passando mais informações com nível de confiabilidade para o governo e a sociedade em geral.

\section{REFERÊNCIAS}

CAON, Alda; NASCIMENTO, Sabrina. Percepção dos discentes de Ciências Contábeis sobre o sistema de Escrituração Digital das Obrigações Fiscais, Trabalhistas e Previdenciária (eSocial). Revista de Contabilidade do Mestrado em Ciências Contábeis da UERJ, v. 22, n. 1, p. 3-27, 2017.

CERQUEIRA, Fabiano Silva. E-social: sped trabalhista e suas mudanças no escritório de contabilidade do município de Governador Mangabeira-Ba. 2017.

DA CRUZ SILVA, Josyele; DE SOUSA, Nadjany Gomes; AYRES, Marcos Aurélio Cavalcante. Esocial: implantação e cumprimento na percepção do profissional contábil. Humanidades \& Inovação, v. 7, n. 9, p. 8-24, 2020.

DA SILVA BRITO, Cynthia Carita Luciano et al. Impactos do e-Social na construção civil e reflexos na segurança do trabalho. Technology Sciences, v. 1, n. 2, p. 15-23, 2019. 
DE AZEVEDO, Katya Cristiane da Fonseca; HABER, Denise Dallmann; MARTINS, Solange. As diferenças entre departamento de recursos humanos e departamento pessoal. Faculdade Integrada INESUL, 2014.

DE OLIVEIRA, Lucimara da Silva; SANTANA, Tayana Pereira; MARTINS, Zilton Bartolomeu. Perspectivas dos contadores em relação à implantação do e-Social. Revista Mineira de Contabilidade, v. 18, n. 2, p. 41-53, 2017.

DIAS, I. M. A relação entre reforma da administração pública e tecnologias de informação no governo do Estado de São Paulo. 2008. 170 f. Tese (Doutorado) - Universidade de São Paulo, São Paulo, 2008.

FERNANDES, C. C. C. Governo eletrônico e transformação da administração pública. In: CHAHIN, A.; CUNHA, M. A.; KNIGHT, P.T.; PINTO, S. L (Org.). e-gov.br: a próxima revolução brasileira: eficiência, qualidade e democracia: o governo eletrônico no Brasil e no mundo. São Paulo: Prentice Hall, 2004.

GOMES, Flávia dos Santos Macedo. A percepção dos profissionais de departamento pessoal nos escritórios de contabilidade em relação a utilização do aplicativo empregador web no município de Cruz das Almas. 2018.

LEAL, J. M. D. R., ROSENDO, L. L. D. S., JÚNIOR, L. A. F., \& SOARES, Y. M. A . (2016).

Implementação do e-Social: benefícios e desafios sob as perspectivas dos profissionais contábeis da Paraíba. Revista Gestão e Organizações, 1(1).

MATOS, Ana Carolina et al. Os impactos da implantação do sistema e-social na rotina dos escritórios de contabilidade: um estudo de caso na cidade de Barroso-MG.

NOGUEIRA, Valdir; FARI, Murilo Arthur. Perfil do profissional contábil: relações entre formação e atuação no mercado de Trabalho. Perspectivas Contemporâneas, v. 2, n. 1, 2007. 
OLIVEIRA, Aristeu de. Sistema de Escrituração Fiscal Digital das Obrigações Fiscais, Previdenciárias e Trabalhistas. Atlas, 2014.

OLIVEIRA, Fernanda Silva de et al. Análise frente a reforma trabalhista e implantação do eSocial nas rotinas dos escritórios de contabilidade de João Pessoa. 2018.

PWC BRASIL. A preparação das empresas para o eSocial. (2014). Disponível em: < https://www.pwc.com.br/pt/publicacoes/servicos/assets/consultoria-negocios/2014/p wcpreparacao-empresas-esocial.pdf >. Acesso em: 20 abr. 2021.

REICHERT, Janice M. Antibodies to watch in 2015. In: MAbs. Taylor \& Francis, 2015. p. $1-8$.

REIS, Eliandro dos. SPED eSocial e as mudanças na rotina dos profissionais de departamento de pessoal de uma empresa concessionária de Caxias do Sul. 2019.

SANCEVERINO, Flávio. O impacto do eSocial no departamento pessoal de um órgão público. Gestão de pessoas-Unisul Virtual, 2019.

SANTOS, Thiago Teixeira. Formação de professores e religiões de matrizes africanas. Interacoes, v. 12, n. 22, p. 409-411, 2017.

SILVA, Wilma Martins da. O e-Social: dificuldades enfrentadas pelos profissionais da Contabilidade. 2019.

UNISUL. Disponível em:

https://riuni.unisul.br/bitstream/handle/12345/7796/Artigo\%20Cient\%C3\%ADfico\%20\%20F lavio\%20Sanceverino.pdf?sequence=1\&isAllowed=y > Acesso em: 09 out. 2020.

VELLUCCI, Rosana Gribl et al. Os desafios da implantação do eSocial. Revista da Micro e Pequena Empresa, v. 12, n. 1, p. 67-81, 2018. 


\title{
OS EFEITOS DA PANDEMIA NOS HÁBITOS COMUNITÁRIOS: UM ESTUDO DE CASO SOBRE A FEIRA LIVRE (PÁTIO NOVO) DO BAIRRO DE AFOGADOS EM RECIFE/PE
}

\author{
https://dx.doi.org/10.48097/2674-8673.2022n6p15
}

\author{
Magali Ferreira de Menezes ${ }^{1}$ \\ Fábio José de Araújo Pedrosa²
}

\section{RESUMO}

As feiras livres fazem parte do cotidiano social nas grandes metrópoles ou nos lugarejos mais longínquos. A pergunta norteadora foi: a pandemia da Covid-19 causou alguma mudança positiva no comportamento dos feirantes do Pátio Novo da Feira Livre de Afogados (PNFLA), no tocante aos hábitos de limpeza e higiene dos feirantes? A coleta de dados ocorreu no período de 23/10/21 a 21/11/21. Foram entrevistados 55 feirantes. O questionário foi o método de coleta de dados. $26 \%$ dos respondentes tinham idade entre 41 e 50 anos e $11 \%$ tinham mais de 60 anos. $53 \%$ são escolarizados e 9\% concluíram o ensino médio. $43 \%$ atuam há mais de 20 anos e $2 \%$ entre 01 e 05 anos. Os proprietários representaram 51\% dos entrevistados e $11 \%$ são feirantes funcionários. Os feirantes têm conhecimento sobre a existência do coronavírus e têm pouca segurança ao afirmarem que conhecem ou desconhecem as formas de contágio. As pessoas que trabalham na feira livre não tiveram suporte técnico e sanitário satisfatório por parte da Prefeitura do Recife para enfrentar a pandemia. Como proposta para pesquisas futuras, propõem-se expandir o estudo para outras feiras livres da região metropolitana do Recife e de outras capitais.

Palavras-chave: Feira livre. Pandemia. Mudança de hábitos. Higiene.

Data de submissão: 22/12/2021

Data de aprovação: 30/12/2021

\section{RESUMEN}

Las ferias libres son parte de la vida social cotidiana en las grandes ciudades o en las regiones longincuas. La pregunta orientadora fue: ¿la pandemia de la covid-19 provocó algún cambio positivo en el comportamiento de los feriantes en el Patio Nuevo de la Feria Libre de Afogados (PNFLA), en relación a los hábitos de limpieza e higiene de los feriantes? La recolecta de datos fue hecha en el periodo comprendido entre el 23/10/21 y el 21/11/21. Se entrevistó a 55 feriantes. El cuestionario fue el método utilizado para la recolecta de datos. El 26\% de los encuestados tienen entre 41 y 50 años y el 11\% tienen más de 60 años, el 53\% son escolarizados y el $9 \%$ han concluido la enseñanza media, el $43 \%$ actúan hace más de 20 años y el $2 \%$ entre 01 y 05 años. Los propietarios representan el 51\% de los encuestados y el 11\% son feriantes

\footnotetext{
${ }^{1}$ Mestra em Gestão do Desenvolvimento Local Sustentável pela Universidade de Pernambuco.

E-mail: magalimenezes@gmail.com

${ }^{2}$ Professor Adjunto da Universidade de Pernambuco e da Universidade Católica de Pernambuco.

E-mail: fabio.eco@terra.com.br
} 
empleados. Los feriantes tienen conocimiento de la existencia del coronavirus y tienen poca seguridad al afirmar que conocen o desconocen las formas de contagio por el nuevo coronavirus. Las personas que trabajan en la feria libre no recibieron soporte técnico y sanitario satisfactorio por parte del ayuntamiento de Recife para enfrentar la pandemia. Como propuesta para investigaciones futuras, se propone ampliar el estudio a otras ferias libres de la región metropolitana de Recife y otras capitales.

Palabras clave: Feria libre. Pandemia. Cambio de habito. Higiene.

\section{INTRODUÇÃO}

Quer conhecer os hábitos de um lugar? Então, entre outras coisas, visite a Feira Livre (FL) e irá descobrir do que costumam se alimentar e a forma com que tratam os seus alimentos.

As FL fazem parte do cotidiano social brasileiro, seja nas grandes metrópoles ou nos lugares mais longínquos. Elas aglutinam pessoas, esbanjam cultura e tradição local. É fonte de renda para muitas famílias e contribui de forma significativa para a saúde coletiva daqueles que de lá se abastecem de frutas, legumes, carnes, pescados, entre outros.

No Brasil, o primeiro e único censo demográfico das Feiras Livres (FL) ocorreu em 2014. $\mathrm{Na}$ ocasião, o relatório indicou o funcionamento de 5.119 feiras livres espalhadas em 1.176 municípios (MDS, 2015), ou seja, um número bastante expressivo para que apenas 01 censo tenha sido realizado, tendo em vista que são parte integrante e muito importante na geração de renda de muitas famílias.

A ausência de realização do censo nas FL colabora diretamente para a falta de controle na ocupação do espaço público, controle sanitário, trabalho infantil, prostituição, venda de drogas e outros tipos de violência.

Considera-se que as FL empregam desde o pequeno agricultor até famílias inteiras, bem como empregos diretos para feirantes, sendo eles donos dos bancos ou empregados e, não menos importante, destacar também a contribuição da FL na segurança alimentar da população.

Em qualquer localidade do Brasil, por menor que seja, tem uma FL. Faz parte do cotidiano dos brasileiros ir à feira em busca de alimentos frescos, com preço acessível e variedade de produtos.

Em estudo recente, Menezes, Freitas e Pedrosa (2021, no prelo) trataram sobre as FL da região Nordeste do Brasil, em cenário anterior à pandemia do novo coronavírus, tendo como estado da arte a confirmação da difícil realidade sanitária vivenciada nes ses centros comerciais.

Dessa forma, a expertise dos autores sobre sustentabilidade ambiental impulsiona a continuidade das pesquisas sobre essa temática. Assim, elegeu-se como pergunta norteadora desse estudo: a pandemia da Covid-19 causou alguma mudança positiva no comportamento dos 
feirantes do Pátio Novo da Feira Livre de Afogados (PNFLA), no tocante aos hábitos de limpeza e higiene dos feirantes? Para tanto, foram eleitos os seguintes objetivos específicos: a) verificar a presença de material gráfico orientativo disponibilizado pelos órgãos sanitários do governo estadual e/ou municipal sobre o combate ao novo coronavírus e/ou as diversas formas de contágio; b) identificar a forma de descarte dos resíduos secos e molhados por parte dos feirantes; c) analisar a percepção dos feirantes sobre a relação entre a limpeza e conservação do ambiente físico e o combate ao novo coronavírus.

\section{REFERENCIAL TEÓRICO}

A primeira pandemia pós-moderna foi provocada pela gripe H1N1 em 2009, mas a grande pandemia causada pelo novo coronavírus, responsável pela Covid-19, é igualmente resultante de uma sociedade globalizada e baseada em informação; que só no Brasil, no período de 11 de março de 2019 até 30 de setembro de 2021, matou mais de 616 mil pessoas. (SILVA, 2003; GOMES E FERRAZ, 2012; GAZETA DO POVO, s.d).

De acordo com Carvalho (2020, p. 93), “a pandemia do coronavírus, da síndrome respiratória aguda grave 2 (SARS-CoV-2) é, como o nome sugere, o segundo surto da doença causada pela família de vírus coronaviridae em menos de 20 anos. Entre 2002 e 2004 mais de 8 mil pessoas foram infectadas e 774 morreram em 29 países e territórios de todo o mundo.”

As várias formas de contágio logo passaram a ser investigadas e amplamente divulgadas em todos os meios de comunicação. Os hábitos de higiene das pessoas, no que tange aos cuidados com os alimentos, consigo e com os outros indivíduos precisaram ser adequados aos novos padrões sanitários. Como citam Menezes e Pedrosa $(2021$, p. 2) "a mudança na rotina das pessoas incluiu desde o uso de máscaras de proteção e higienização das mãos de forma constante até o isolamento social, situação nunca vivida pela atual geração. Essa mudança de hábito, imposta pela necessidade de sobrevivência, impactou todas as áreas da economia em escala mundial".

Diante da nova realidade sanitária, situações do cotidiano que muitas vezes passavam despercebidas ganharam novamente a atenção devida por parte da sociedade. Dentre estas, estava a atenção com a qualidade dos produtos e a higiene nas feiras livres (FL), que representam um dos tipos de comércio mais antigos que se tem registro. Oferecem produtos alimentícios, produtos de reparos domésticos de pequeno porte, utensílios para animais domésticos, entre outros.

De acordo com Menezes (2019), as feiras livres (FL) possuem 03 categorias distintas: feira local ou feira de consumo dos compradores rurais, feira de distribuição e feira de 
abastecimento ou Feira de Consumidores Urbanos. Elas são de grande relevância socioeconômica, tendo como um dos fatores o fortalecimento da manutenção de empregos diretos e indiretos, em destaque o período da pandemia da Covid-19. (FREITAS, BARBOSA e SOARES, 2020).

Como orienta Franco, Landgraf e Pinto (2020, p. 6) "medidas preventivas simples relacionadas à higiene dos alimentos, do ambiente e das mãos devem ser implementadas por todos os atores da cadeia de produção alimentícia para manter o Sars-CoV-2 e outros microorganismos patogênicos longe do ambiente de produção e da mesa do consumidor".

Nesse contexto, as FL são reconhecidas como parte integrante desse processo e com muita responsabilidade, haja vista responder pelo abastecimento de grande parte da população.

Pelos estudos ora publicados, conseguiu-se identificar uma necessidade urgente e importante de melhoria nas FL da região Nordeste do Brasil, no que concerne às condições sanitárias antes da pandemia do novo coronavírus, e intensificadas no decorrer desta. A precariedade sanitária nas FL, principalmente da região Nordeste do Brasil, tem forte relação com o descaso do poder público diante das suas responsabilidades legais, bem como pela pequena consciência ambiental dos feirantes, o que resulta em hábitos de higiene que vão de encontro aos conceitos da educação ambiental.

A educação é um dos pilares fundamentais para a mudança de comportamento social. Dessa forma, Lima (2019, p. 9) compreende a educação ambiental como sinônimo da educação para a sustentabilidade e que o objetivo desta é "sensibilizar a população sobre as questões ambientais e possibilitar discussões que contribuam para a reflexão do indivíduo, corroborando com a busca e a construção de alternativas sociais, baseadas em princípios ecológicos, éticos e de justiça”.

Sendo assim, o arcabouço teórico ora apresentado serviu para embasar a pesquisa com a finalidade de responder se a pandemia da Covid-19 causou alguma mudança positiva no comportamento dos feirantes do Pátio Novo da Feira Livre (FL) de Afogados - Recife/PE, no tocante aos hábitos de limpeza e higiene. 


\section{MATERIAL E MÉTODO}

De acordo com Gil (2019), Lakatos e Marconi (2021) e Bardin (2006), o estudo caracterizou-se como de natureza aplicada, com o objetivo exploratório e descritivo, e estudo de caso único. Utilizou-se o método qualitativo-quantitativo e análise de conteúdo.

O locus da pesquisa foi o Pátio Novo da Feira Livre de Afogados (PNFLA), localizado entre as ruas General Christóvam Colombo de Souza e João Carlos Guimarães, no bairro de Afogados - Recife/PE, como pode ser observado na figura 1, onde se vê o mapa da Região Político Administrativa 05, com o PNFLA em destaque.

Figura 1 - Mapa da RPA 05, com destaque para a localização do PNFLA.

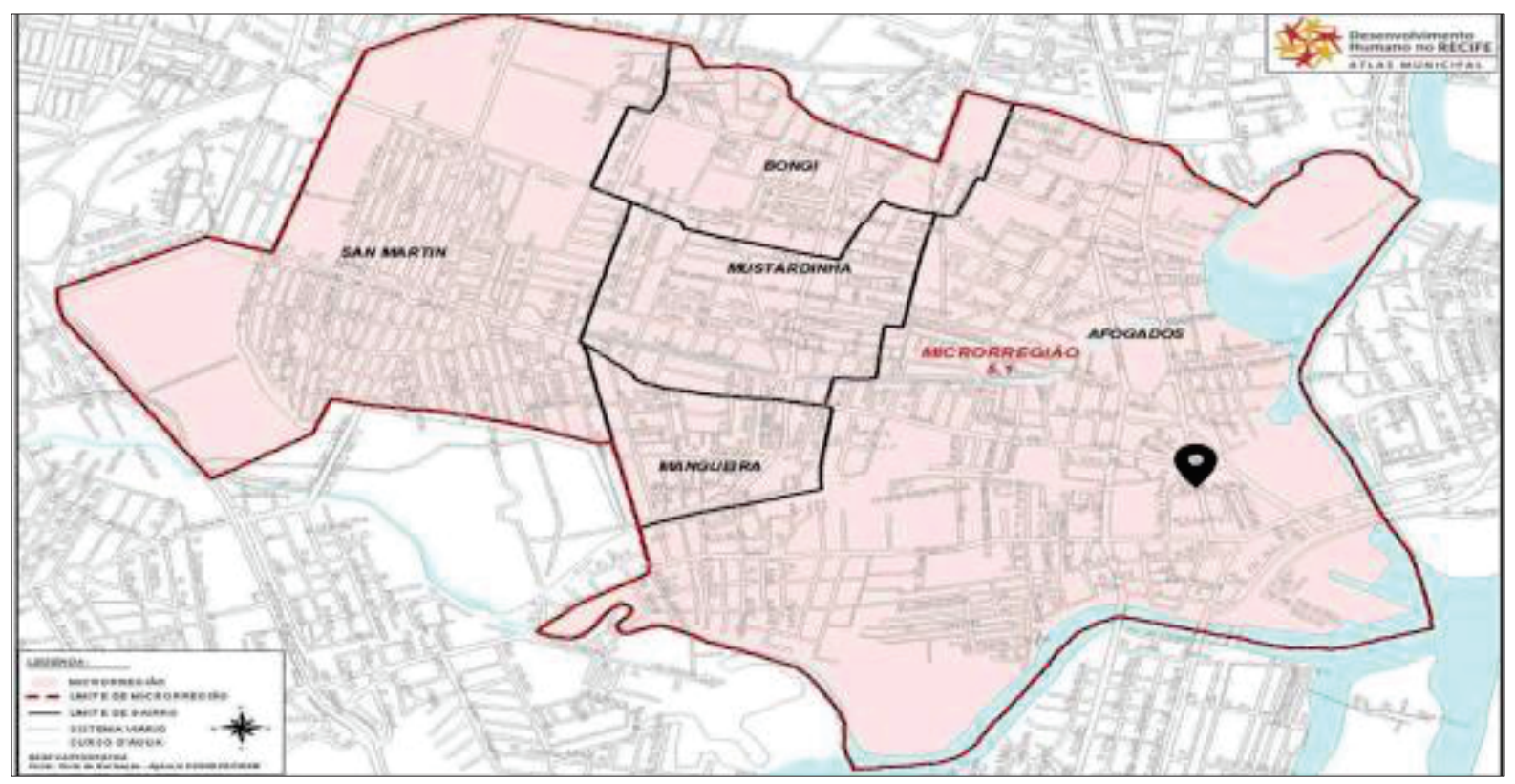

Fonte: Prefeitura da Cidade do Recife - Adaptado pelos autores.

A coleta de dados ocorreu entre os dias 23/10/21 a 21/11/21, em 03 visitas. Foram abordados 82 feirantes, dos quais 55 participaram da pesquisa respondendo aos questionários e 27 optaram por não participar. Todos foram abordados seguindo os protocolos de segurança sanitária orientados pelos órgãos competentes e um script pré-definido: primeiramente, fazendo uma saudação (bom dia, boa tarde); depois foi explicada de forma sucinta sobre o objetivo da pesquisa; e por fim, àqueles que se mostraram receptivos, foi mantido um diálogo mais aprofundado no qual explicou-se com mais detalhes os objetivos da pesquisa e mencionados os estudos anteriores.

A amostra contemplou exclusivamente os feirantes que comercializam nos bancos fixos, por estarem com sua situação regular perante a Prefeitura do Recife e possibilitando maior controle entre as recusas e aceites para participar da pesquisa. 
O questionário com perguntas objetivas e subjetivas foi o método de coleta de dados escolhido e estruturado em 03 partes: perfil socioprofissional com perguntas objetivas; conhecimento sobre o coronavírus e suas formas de contágio; e hábitos de higiene e limpeza do ambiente físico da feira livre antes e durante a pandemia com perguntas subjetivas, e utilizando o método de análise de conteúdo. (BARDIN, 2006).

\section{RESULTADOS}

Os resultados obtidos com a pesquisa foram discutidos nesta seção. Para responder aos objetivos específicos:

a) verificar a presença de material gráfico orientativo disponibilizado pelos órgãos sanitários do governo estadual e/ou municipal sobre o combate ao novo coronavírus e/ou as diversas formas de contágio;

b) identificar a forma de descarte dos resíduos secos e molhados por parte dos feirantes;

c) analisar a percepção dos feirantes sobre a relação entre a limpeza e conservação do ambiente físico e o combate ao novo coronavírus.

Para isso, foram necessárias 03 visitas ao Pátio Novo da Feira Livre de Afogados (PNFLA).

Verificou -se que dos 194 bancos existentes, apenas 82 deles estavam em funcionamento nas datas em que ocorreram as visitas, sendo a amostra constituída pelos 55 feirantes que aceitaram responder ao questionário, como pode ser verificado no quadro 01.

Quadro 01 - Visitas ao PNFLA e quantidade de Feirantes respondentes

\begin{tabular}{|c|c|c|c|c|}
\hline Feira & Horário & $\begin{array}{c}\text { Feirantes } \\
\text { Abordados }\end{array}$ & $\begin{array}{c}\text { Aceitaram } \\
\text { responder }\end{array}$ & $\begin{array}{c}\text { Recusaram } \\
\text { responder }\end{array}$ \\
\hline $23 / 10$ & $12 \mathrm{~h} 30$ & 25 & 18 & 07 \\
\hline $06 / 11$ & $15 \mathrm{~h} 00$ & 37 & 22 & 15 \\
\hline $21 / 11$ & $11 \mathrm{~h} 00$ & 20 & 15 & 05 \\
\hline
\end{tabular}

Fonte: os autores (2021).

Sobre a negativa em responder ao questionário, os feirantes apontaram vários motivos, como pode ser verificado no quadro 02 , que apresenta a categorização das respostas mais citadas.

A recusa dos feirantes no tocante a responder ao questionário foi categorizada da seguinte forma: os feirantes abordados na visita do dia 23/10 foram identificados com a letra "A", do dia 06/11 receberam a letra "B", e do dia 21/11 a letra "C", conforme exposto no quadro 2. 
Quadro 2 - Categorização sobre a disponibilidade e interesse em participar da pesquisa

\begin{tabular}{|c|c|r|}
\hline Expressões & Quant. & Algumas das Respostas obtidas por meio dos Feirantes \\
\hline Vergonha & 28 & $\begin{array}{r}\text { "Eu tenho vergonha de responder." (Feirante A 2) } \\
\text { "Deus me livre e guarde, tenho muita vergonha." (Feirante B 8) } \\
\text { "Não gosto de responder pesquisa, tenho vergonha." (Feirante C 5) }\end{array}$ \\
\hline Tempo & 25 & $\begin{array}{r}\text { "Eu 'tô' ocupado demais." (Feirante A 14) } \\
\text { "Eu nem posso falar com você agora." (Feirante B 9) }\end{array}$ \\
\hline Interesse & 21 & $\begin{array}{r}\text { "Não "tô' interessada em saber do que se trata." (Feirante A 8) } \\
\text { "Esse assunto é bom falar com a Prefeitura." (Feirante B 14) } \\
\text { "Ganha alguma coisa para responder?" (Feirante C 11) }\end{array}$ \\
\hline
\end{tabular}

Fonte: os autores (2021).

O perfil socioprofissional dos respondentes foi categorizado por meio de perguntas objetivas e composto dos seguintes dados:

a) Idade;

b) Nível de escolaridade;

c) Tempo de atuação como feirante;

d) Tipo de vínculo profissional que mantém com a feira.

Os resultados obtidos foram expostos nos gráficos 1,2, 3 e 4, apresentados a seguir: 
Gráficos 1 e 2 - Faixa etária e escolaridade dos respondentes
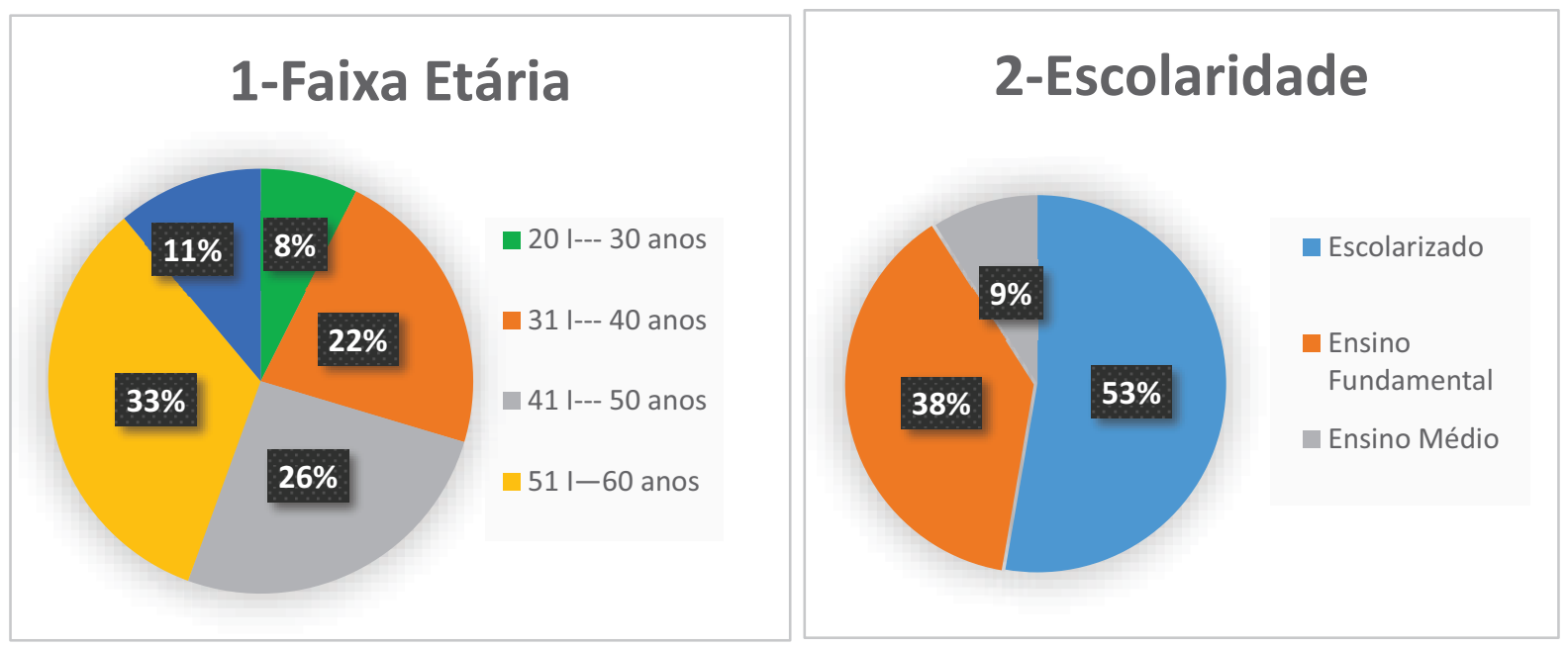

Fonte: os autores (2021)

Verificou -se, a partir dos gráficos apresentados, que 26\% dos respondentes tinham idade entre 41 e 50 anos, e 11\% tinham mais de 60 anos. Dos 55 respondentes, 53\% são escolarizados e apenas $9 \%$ concluíram o ensino médio.

Gráficos 3 e 4 - Tempo de atuação como feirante e tipo de vínculo

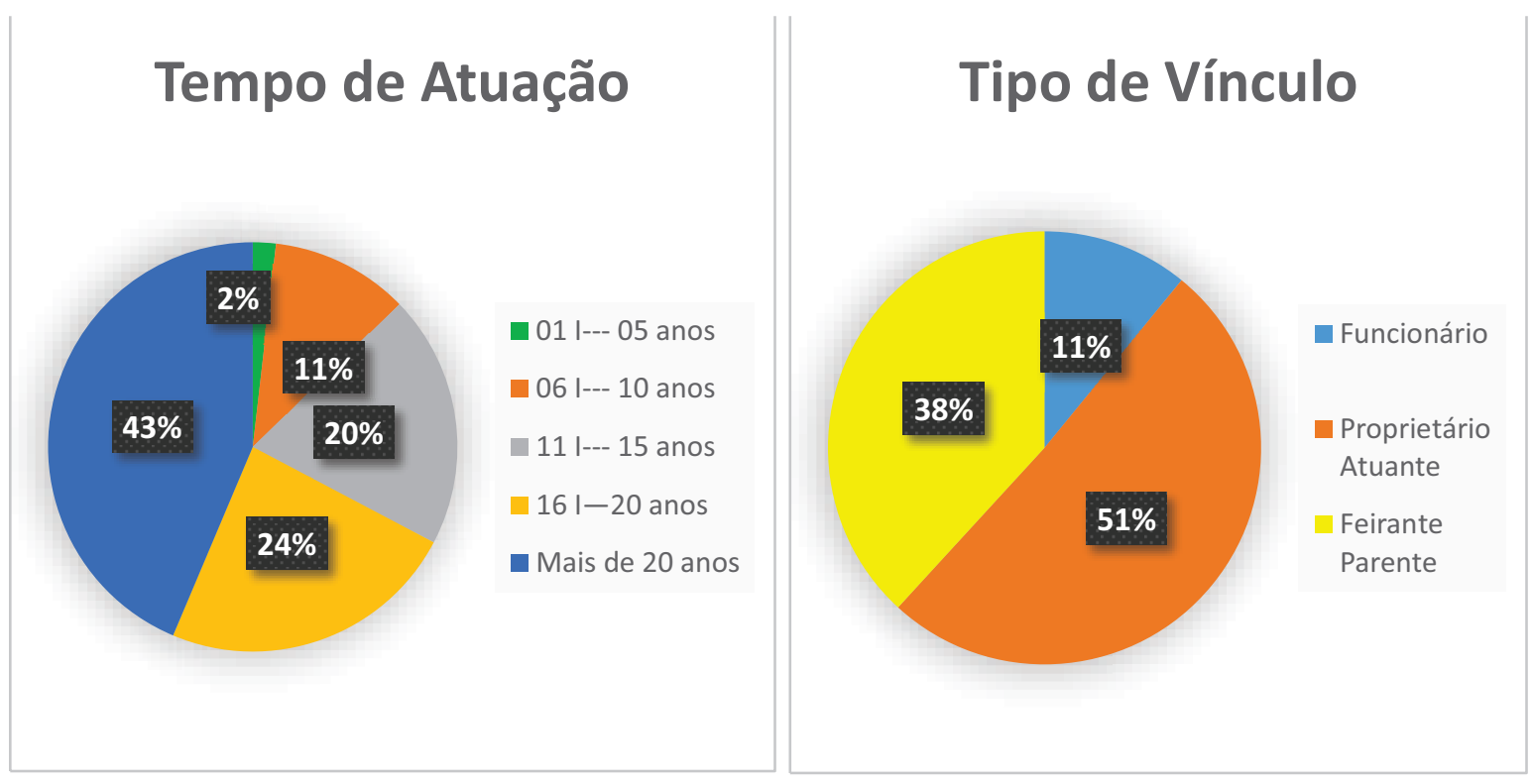

Fonte: os autores (2021)

Dos feirantes pesquisados, $43 \%$ atuam há mais de 20 de anos e $2 \%$ entre 01 e 05 anos. Os proprietários representaram $51 \%$ dos entrevistados, e $11 \%$ foi o percentual dos feirantes que são apenas funcionários. 
O conhecimento sobre o coronavírus e suas formas de contágio, e os hábitos de higiene e limpeza do ambiente físico da feira livre antes e durante a pandemia foram verificados por meio de perguntas subjetivas, tais como: você sabe o que é o novo coronavírus? Se sim, sabe as formas de contágio? Sabe dizer pelo menos uma forma de contágio? Se você sabe as formas de contágio do novo coronavírus, houve alguma mudança nos seus hábitos de higiene e limpeza aqui na feira?

A sequência de número 01 a 55 foi a forma utilizada para identificar os feirantes respondentes nos quadros 03 a 06, os quais contemplaram respostas subjetivas.

As definições sobre o que é coronavírus, na visão dos feirantes, foram compiladas e apresentadas no quadro 3 .

Quadro 3 - Você sabe o que é o novo coronavírus?

\begin{tabular}{|c|c|c|}
\hline Expressões & Quant. & Algumas das Respostas obtidas por meio dos Feirantes \\
\hline $\begin{array}{l}\text { Aquele } \\
\text { negócio }\end{array}$ & 08 & $\begin{array}{l}\text { “Aquele negócio que ‘tá’ matando o povo.” (Feirante 03) } \\
\text { “Aquele negócio que parece uma gripe.” ((Feirante 16) } \\
\text { “Aquele negócio que 'tá' enchendo os hospital.” (Feirante 42) }\end{array}$ \\
\hline $\begin{array}{l}\text { Aquele } \\
\text { 'microbo' }\end{array}$ & 02 & $\begin{array}{l}\text { “Aquele 'microbo' que mata os 'velho'.” (Feirante 09) } \\
\text { “Aquele 'microbo' que não tem remédio.” (Feirante 35) }\end{array}$ \\
\hline $\begin{array}{l}\text { Aquela } \\
\text { doença }\end{array}$ & 45 & $\begin{array}{l}\text { “Aquela doença que mata muitas 'pessoa' de uma vez.” (Feirante 11) } \\
\text { “Aquela doença que não deixa a gente ir pra rua.” (Feirante 39) } \\
\text { “Aquela doença que tem que usar máscara.” (Feirante 55) }\end{array}$ \\
\hline
\end{tabular}

As respostas apresentadas no quadro 3 indicaram que os feirantes têm conhecimento sobre a existência do coronavírus, bem como do seu potencial de letalidade, ainda que não tenham reconhecido como "vírus" e sim como "micróbio".

O conhecimento sobre as formas de contágio pelo novo coronavírus é de grande importância para os feirantes, tendo em vista a contribuição da feira livre para a segurança alimentar da população, como pode ser verificado no quadro 4. 
Quadro 4 - Conhece as formas de contágio pelo novo coronavírus?

\begin{tabular}{|c|c|c|}
\hline Expressões & Quant. & Algumas das Respostas obtidas por meio dos Feirantes \\
\hline $\begin{array}{l}\text { Mais ou } \\
\text { menos }\end{array}$ & 07 & $\begin{array}{l}\text { “'Mai ou meno', tudo, tudo eu não sei.” (Feirante 08) } \\
\text { “’Rapai', mais ou 'meno', é complicado.” ((Feirante 26) } \\
\text { “Eu digo que conheço mais ou 'meno'.” (Feirante 49) }\end{array}$ \\
\hline Sei como é & 13 & $\begin{array}{l}\text { “Eu sei como é.” (Feirante 23) } \\
\text { "Sei como é pra mim, 'pros' ‘outro’ não.” (Feirante 47) }\end{array}$ \\
\hline Conheço & 35 & $\begin{array}{l}\text { “Conheço demais minha gente.” (Feirante 14) } \\
\text { “Conheço muito 'mermo'.” (Feirante 37) } \\
\text { “conheço de 'vê' na internet.” (Feirante 51) }\end{array}$ \\
\hline
\end{tabular}

Fonte: os autores (2021)

Com base nas respostas apresentadas no quadro 4, percebeu-se que os feirantes têm pouca segurança ao afirmarem que conhecem ou desconhecem as formas de contágio pelo novo coronavírus. Fato que deveria preocupar tanto a população quanto o poder público.

Para confirmar se os feirantes sabiam as formas de contágio pelo novo coronavírus, foi pedido que explicassem "como" se dá o contágio, conforme apresentado no quadro 5.

Quadro 5 - Informe pelo menos uma forma de contágio?

\begin{tabular}{|c|c|r|}
\hline Expressões & Quant. & Algumas das Respostas obtidas por meio dos Feirantes \\
\hline Vento & 05 & "O vento que traz e entra na gente." (Feirante 05) \\
"A gente pega pelo vento." ((Feirante 29) \\
"Fariz
\end{tabular}

Fonte: os autores (2021) 
Todas as formas de contágio indicadas pelos feirantes são reconhecidas como verdadeiras, indicando que eles têm consciência bem definida de como podem ser contaminados ou contaminar outra pessoa.

Quadro 6 - Você mudou algum háb ito de higiene no seu banco e/ou a área onde você trabalha?

\begin{tabular}{|c|c|r|}
\hline Expressões & Quant. & Algumas das Respostas obtidas por meio dos Feirantes \\
\hline $\begin{array}{c}\text { Não tem } \\
\text { como }\end{array}$ & 29 & $\begin{array}{r}\text { "O que é a gente pode mudar? Não tem como." (Feirante 28) } \\
\text { "Eu tentei mudar alguma coisa, mas não tem como." ((Feirante 41) } \\
\text { "Não tem como mudar nada, ninguém aqui conseguiu." (Feirante 53) }\end{array}$ \\
\hline $\begin{array}{c}\text { Saquinhos } \\
\text { de redinha }\end{array}$ & 09 & $\begin{array}{r}\text { "Eu 'tô' fazendo os saquinhos de redinha." (Feirante 12) } \\
\text { "Com saquinho de redinha o freguês não mexe." (Feirante 19) }\end{array}$ \\
\hline $\begin{array}{c}\text { Não } \\
\text { precisa }\end{array}$ & 11 & $\begin{array}{r}\text { "Não precisa, tem que lavar quando chegar em casa." (Feirante 06) } \\
\text { "Não precisa, já vem da Ceasa sujo." (Feirante 24) }\end{array}$ \\
& "Não precisa, o povo come as coisas aqui e nem lava." (Feirante 38) \\
\hline
\end{tabular}

Fonte: os autores (2021)

Ao analisar as respostas dos feirantes expostas no quadro 6, percebeu-se que apenas 01 mudança foi realizada em toda forma de trabalho, limpeza e higiene do ambiente físico da feira. Vincula-se esse cenário à ausência de orientação e acompanhamento técnico relatado pelos feirantes.

Foi perguntado para todos os feirantes entrevistados se houve alguma orientação por parte da Prefeitura ou órgão sanitário. Todos eles foram unânimes em afirmar que não houve qualquer tipo de orientação além dos cartazes fixados em poucos pontos da feira. 
Figura 01a - Descarte de máscara de proteção e resíduos Figura 01b - Reaproveitamento de alimentos

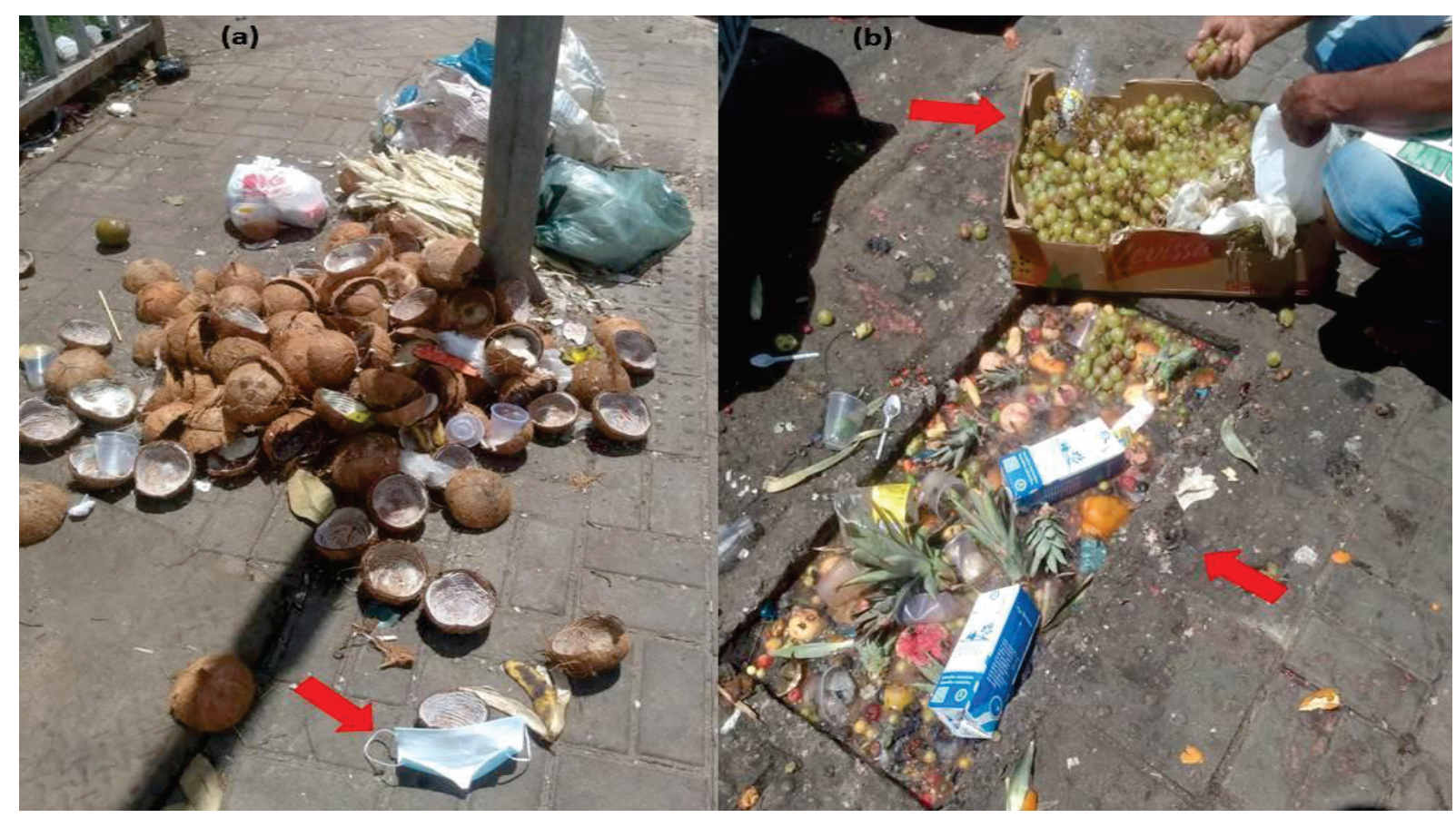

Fonte: os autores (2021)

Pode ser verificado na figura 1 a o descarte indevido de resíduo orgânico e não orgânico. Chama-se a atenção para a máscara facial de uso não profissional descartada no chão, juntamente com os demais resíduos, situação avessa ao que que orienta os órgãos de saúde como o Centro Estadual de Vigilância em Saúde do Rio Grande do Sul (2020): “esses materiais, após utilizados, não devem ser colocados diretamente na lixeira, mas embalados em saco plástico, e também não devem ser misturados com materiais recicláveis".

A figura $1 \mathrm{~b}$ registrou o momento em que um catador de material reciclável es tava separando as frutas que ainda tinham condições para consumo, dispostas em uma caixa colocada no chão, ao lado de um esgoto aberto e repleto de resíduos orgânicos e não orgânicos. Uma situação desnecessária e comum na rotina das FL. 
Figura 02a - Presença de animais na área interna do PNFLA

Figura 02b - Exposição de resíduos orgânicos e não orgânicos

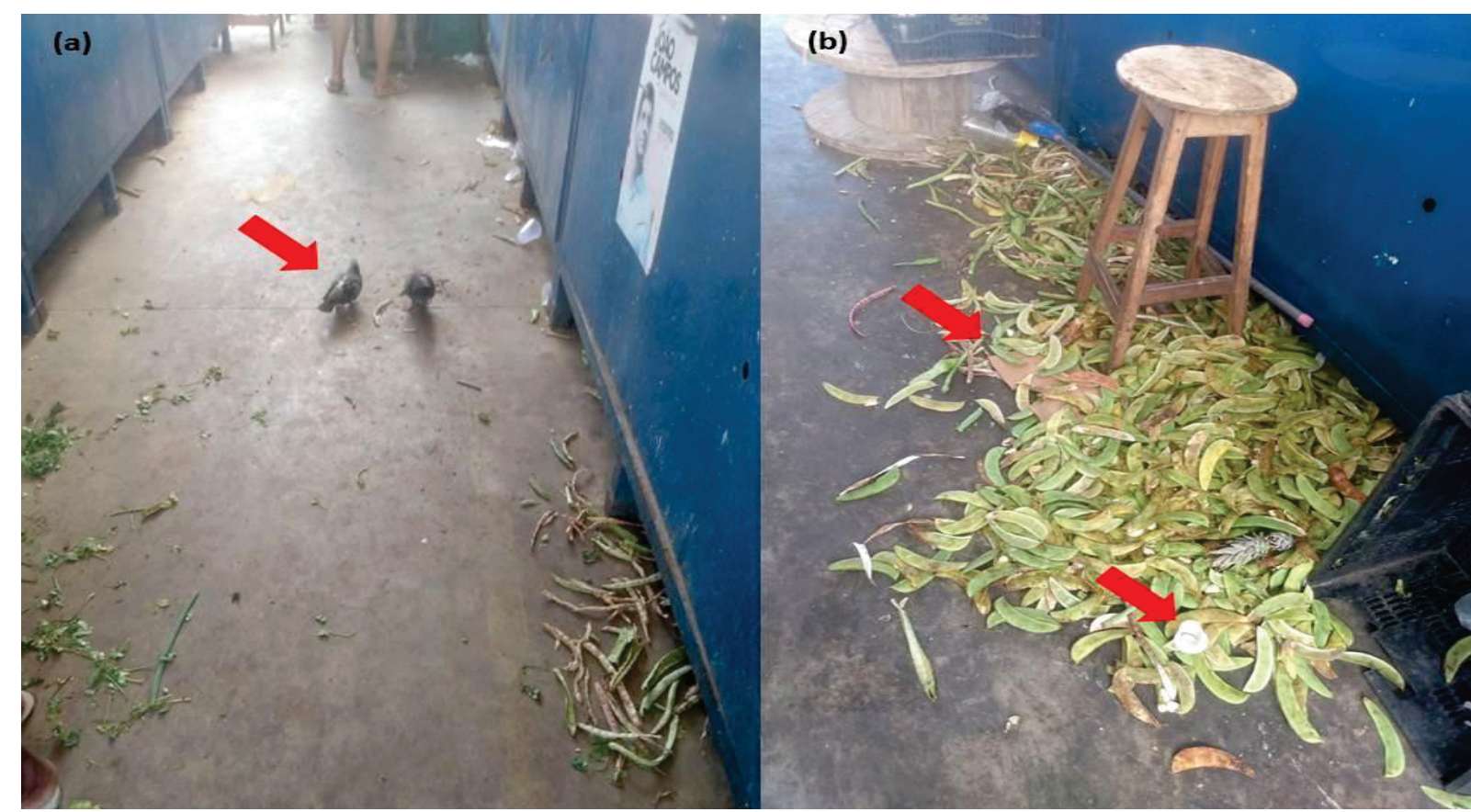

Fonte: os autores (2021)

Nas figuras 02a e 02b foi registrada a presença de aves na área interior da feira, transitando entre os bancos de forma livre e muito próximo dos alimentos e resíduos, que mais uma vez confirma a difícil realidade no que tange às condições de higiene e limpeza do PNFLA. Vale destacar que os coletores de resíduos disponibilizados pela Prefeitura do Recife encontravam-se a menos de 150 metros do local apresentado nas figuras 02 .

Se os coletores são disponibilizados pela Prefeitura, por qual motivo o PNFLA tem os resíduos descartados erroneamente, mesmo com a presença do novo coronavírus ainda causando o óbito de tantas pessoas?

Nessa perspectiva, indica-se à Prefeitura do Recife atuar de forma mais ativa em ações de conscientização e educação ambiental, bem como em boas práticas na manipulação de alimentos, objetivando melhorar o comprometimento dos feirantes com a higiene e limpeza do ambiente físico do PNFLA.

\section{CONCLUSÃO}

A Feira Livre (FL) está presente no cotidiano da sociedade e é um ambiente de muita movimentação, seja de pessoas quanto de produtos diariamente, com isso possui alto potencial para o contágio pelo novo coronavírus, que se destaca nesse momento da primeira pandemia do século XXI. Dessa forma, observou-se que os feirantes do PNFLA têm conhecimento sobre os 
riscos e as formas de contágio, porém, isso não foi suficiente para mudar a rotina deles no que tange à limpeza e conservação do ambiente físico do PNFLA. As pessoas permanecem aglomerando e pouquíssimos clientes e feirantes foram vistos utilizando máscaras de proteção.

Uma iniciativa simples e prática adotada por poucos foi o ensacamento das frutas e legumes em "saquinhos de redinha", como é chamado o saco rede de plástico, o qual evita a manipulação direta dos produtos.

As pessoas que trabalham na feira livre não tiveram suporte técnico e sanitário satisfatório por parte da Prefeitura do Recife para enfrentar a pandemia. Essa é a maior constatação desse trabalho.

Então, a pandemia só agravou o caos ambiental presente nas feiras livres. E isso só confirma o resultado apresentado neste estudo, bem como em vários outros publicados pelos autores.

Para que as FL continuem existindo, é muito importante que haja um projeto robusto com foco na melhoria da consciência e educação ambiental dos feirantes para que possa haver a mudança de comportamento ambiental nesses espaços.

A fragilidade sanitária nas feiras livres compromete a continuidade desse símbolo de cultura e tradição, além da manutenção de tantas famílias que de lá tiram seus sustentos.

É preciso que haja mais censos, empenho dos governantes de todas as esferas e enxergar a feira como um lugar tão importante quanto parques, praças e praias no controle da pandemia.

Dessa forma, sugere-se aos órgãos competentes adotar o plano estratégico apresentado por Menezes (2019), no qual inclui diversas ações que se utilizadas poderão melhorar significativamente a consciência ambiental dos feirantes do PNFLA.

Como proposta para pesquisas futuras, propõem-se expandir o estudo para outras feiras livres da região metropolitana do Recife e de outras capitais.

\section{REFERÊNCIAS}

BARDIN, L. (2006). Análise de conteúdo. (L. de A. Rego \& A. Pinheiro, Trads.). Lisboa: Edições 70. (Obra original publicada em 1977).

BRASIL. Ministério do Desenvolvimento Social. Pesquisa Sobre Segurança Alimentar e Nutricional Começa em Agosto, 2015. Disponível em: https://www.sna.agr.br/mapeamentodo-mds-identifica-em-torno-de-64-mil-feiras-livres-e-agroecologicas-em-todo-pais/. Acesso em: 30 nov. 2021.

CARVALHO, R. A. Doenças Infecciosas Emergentes na Fronteira do Desmatamento. In: YOUNG, C. E. F.; MATHIAS, J. F. C. M. Covid-19, Meio Ambiente e Políticas Públicas São Paulo: Hucitec, 2020. Parte II. pág. 93 - 100. Disponível em: 
http://www.huciteceditora.com.br/ imagens/_downloads/Covid19\%20Meio\%20Ambiente\%20e\%20Politicas\%20Publicas.pdf. Acesso em: 28 nov. 2021.

FRANCO, B. D. G. de M.; LANDGRAF, M.; PINTO, U. M. Alimentos, Sars-CoV-2 e Covid19: contato possível, transmissão improvável. Estudos Avançados, [S. 1.], v. 34, n. 100, p. 189-202, 2020. DOI: 10.1590/s0103-4014.2020.34100.012. Disponível em: https://www.revistas.usp.br/eav/article/view/178768. Acesso em: 02 dez. 2021.

FREITAS, E. P.; BARBOSA, A. F.; SOARES, O. M. S. O Impacto da Pandemia Sobre As Feiras Livres: Caso Corumbá-MS. v. 3 n. 2 (2020): Espaço Tempo Midiático: Edição Especial Covid-19. Disponível em: https://sistemas.uft.edu.br/periodicos/index.php/ midiaticos/issue/view/ISSN\%20-\%202526-5725. Acesso em: 30 nov. 2021.

GAZETA DO POVO. Números do Coronavírus (s.d). Disponível em: https://especiais.gazetadopovo.com.br/coronavirus/numeros/. Acesso em: 07 dez. 2021.

GIL, A. C. Métodos e técnicas de pesquisa social. 7. ed. São Paulo: Atlas, 2019.

GOMES, I. M. A. M; FERRA, L. M. R. Ameaça e controle da gripe A(H1N1): uma análise discursiva de Veja, IstoÉ e Época. Rev. Saúde e Sociedade, Volume: 21, Número: 2 (2012). p.302-313. DOI: 10.1590/S0104-12902012000200005. Disponível em: https://www.revistas.usp.br/sausoc/article/view/48709. Acesso em: 04 nov. 2021.

LAKATOS, E. M.; MARCONI, M. A. Metodologia do Trabalho Científico. 9. ed.São Paulo: Atlas, 2021.

LIMA, L. O. Práticas Pedagógicas em Educação Ambiental nas Escolas Públicas Municipais do Recife. Dissertação de Mestrado apresentada ao Programa de Pós-Graduação em Gestão do Desenvolvimento Local Sustentável da Universidade de Pernambuco, 2019. Disponível em: https://w1files.solucaoatrio.net.br/atrio/upegdls_upl//THESIS/223/lcia de oliveira_dissertao_final_20191218095619929.pdf. Acesso em: 25 out. 2021.

MENEZES, M. F. Subsídios para a Implantação dos 5R's da Sustentabilidade na Feira Livre de Afogados - Recife/PE. Dissertação de Mestrado apresentada ao Programa de PósGraduação em Gestão do Desenvolvimento Local Sustentável da Universidade de Pernambuco, 2019. Disponível em: https://w1files.solucaoatrio.net.br/atrio/upegdls_upl//THESIS/209/dissertao_magali_ferreira_de_menezes_2019072611330872.pdf. Acesso em: 20 out. 2021.

MENEZES, M. F.; FREITAS, N. M. V.; PEDROSA, F. J. A. As Feiras Livres do Nordeste: uma Análise Acerca da Higiene e Conservação do Ambiente Físico (no prelo).

MENEZES, M. F.; PEDROSA, F. J. A. Muda-se de Lugar, Mantém-se os Hábitos: Estudo Sobre a Feira Livre do Bairro de São José- Recife/PE. Revista Equador (UFPI), Vol. 10, N 1, Ano, 2021, p. 287 - 302. Disponível em:

https://revistas.ufpi.br/index.php/equador/article/view/12755/7485. Acesso em: 30 nov. 2021.

RECIFE - MAPA DA RPA 05. Disponível em: (https://www.recife.pe.gov.br/pr/secplanejamento/pnud2005/micro\%205_1.jpg). Acesso em: 10 nov. 2021. 
RIO GRANDE DO SUL. SECRETARIA DE SAÚDE. Saiba como descartar e higienizar corretamente as máscaras de proteção. Disponível em: https://saude.rs.gov.br/saiba-comodescartar-e-higienizar-corretamente-as-mascaras-de-protecao. Acesso em: 20 dez. 2021.

SILVA, L. J. A Globalização da doença. Rev. Saúde Pública, vol. 37 n. 3. DOI: 10.1590/S0034-89102003000300001.

Disponível

em: https://www.scielo.br/j/rsp/a/XX6YtN4jjqVjNdFMsJMPMRL/?lang=pt Acesso em: 06 dez. 2021. 


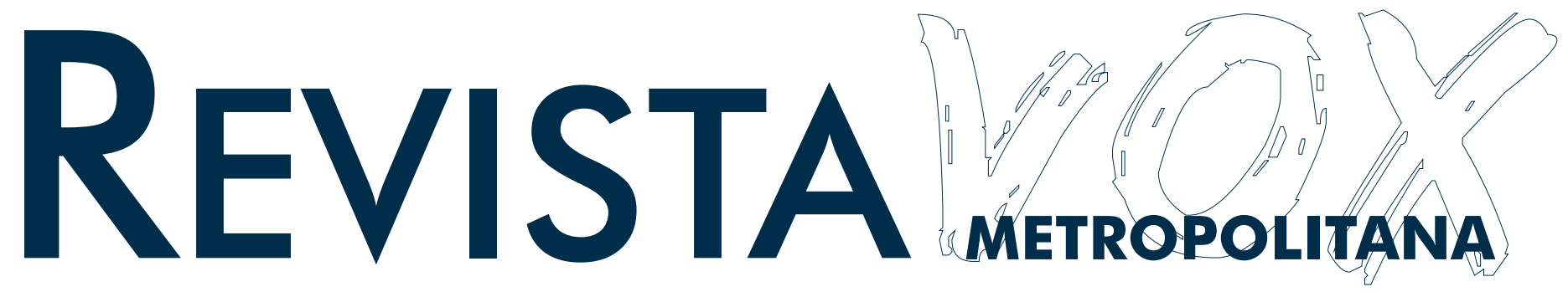

